\title{
SHARECROPPING IN THE YEMEN: \\ A STUDY IN ISLAMIC THEORY, CUSTOM AND PRAGMATISM
}

\author{
William J. Donaldson
}

Thesis presented for the Degree of Doctor of Philosophy to the Department of Islamic and Middle Eastern Studies

The University of Edinburgh

1998

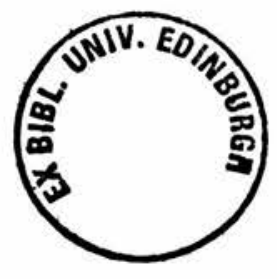


The aim of this thesis is to discuss sharecropping in the Yemen against the background of customary law (curf) on the one hand and Islamic law (the Sharīcah) on the other. Sharecropping is of particular interest in the Islamic context since the practice is widespread in the Yemen and other Islamic countries and is sanctioned by customary law, and yet its very basis (rent as a proportion of a future harvest, which is by definition unknown at the time the contract is drawn up) would seem to be inconsistent with the Islamic prohibition against transactions which involve gharar (risk or uncertainty) and ribä (speculative interest).

The first half of the thesis is to do with how Islamic law views sharecropping in theory, and the information for this is drawn from a variety of primary and secondary literary sources. After a brief review of the rationale of sharecropping and its main features on the world scale, the focus is then brought onto the specifically Islamic aspects of the practice. The theoretical relationship between Islamic law and customary law is first discussed. Then those bad7ths (Traditions) which mention sharecropping and which form the starting point of all Islamic legal discussion are examined in detail, and how they are reflected in the modern Yemeni Civil Code is considered. This is followed by a detailed textual analysis of the views on sharecropping of four eminent Islamic jurists, chosen to represent the two main madhhabs (legal schools) to which most Yemeni jurists adhere: the Shäfici School and the Zaydi School. The selected texts are the chapters on sharecropping in works by al-Shäfici (d. 204/820) and al-Nawawī (d. 676/1277), representing the Shāficīs, and al-Mahdī Ibn al-Murtad̄a (d. 840/1437) and al-Shawkāni (d. 1250/1834), representing the Zaydis .

The focus of the second half of the thesis is on sharecropping as it exists in practice in the Yemen. Here, a variety of textual sources (including written contracts and pleas, and fatwas) has been complemented by information derived from interviews with farmers and other knowledgeable parties made during two field visits to the Yemen. The current situation and arrangements are analysed as they exist first in sharecropping land, and then in sharecropping animals, the latter being an aspect of sharecropping which is generally overlooked. Finally, attention is given to sharecropping contracts and pleas and how disputes are resolved in the Yemen in practice. 


\section{DECLARATION}

I hereby declare that this thesis has been written by myself alone and is wholly the result of my own research.

William J. Donaldson

July 1998 
I wish to thank all those who have contributed to enabling me to write this thesis and to collect the information on which it is based. First and foremost, I owe an immense debt of gratitude to the late Professor R.B. Serjeant. It was he who first suggested to me the topic of sharecropping in the Yemen, and it was through the substantial help and kindness he extended to me, literally right up to the day before he died, that I was able to make a start on the research. My thanks are also due to Mrs Marion Serjeant for her hospitality on many occasions.

I should also like to express my great appreciation for the help, support and encouragement I have received from the members of staff of the Department of Islamic and Middle Eastern Studies of the University of Edinburgh over the eight years I have been ássociated with the department, first as a student, then briefly as a temporary lecturer, and now again as a student. Dr Carole Hillenbrand, who has latterly been my principal supervisor, has always been ready to give her time generously to dispense help and counsel, and she deserves my particular thanks. Dr Michael McDonald, my second supervisor, has also afforded considerable time and assistance, especially in the early days in helping me get to grips with some of the more difficult parts of the primary texts which form a central part of the thesis. I should also particularly like to mention Professor Yasir Suleiman for his wholehearted support over the years.

In addition, I am very grateful to many in the Yemen who have helped me in this research. In particular, I should like to mention H.E. Dr Husayn al-cAmri, both in his capacity as the Yemeni ambassador to London, and also as a renowned scholar; the Qādi Ismācill bn ${ }^{c} A l i \bar{i}$ al-Akwac of Sanc $\bar{a}$, for his early wise advice in my fieldwork; and Dr ${ }^{c} A b d$ al-Wahhāb Rāwih, formerly Dean of the Faculty of Arts, University of Sanca,', for much practical help during my stays in the Yemen. Also in the Yemen, I owe thanks to numerous public officials of several Yemeni government ministries and institutions for easing my way, including, in Sancā', Mr Khālid al-Suraybī, Mr Muhammad al-Suwärī, and others of the staff of the Yemeni Research Centre (Markaz al-Diräsāt wa-al-Buhüth al-Yaman̄î), especially Dr Murshid Shamsān Ahmad for his considerable generosity in allowing me sight of documents and other works not otherwise available. In addition, thanks must be given to the staff of the Yemeni Ministry of Agriculture and its regional offices. I should particularly like to mention the following:

In Sancā', Mr 'Abd al-Wahhāb Ghanimah, head of the Agricultural Extension Centre (Markaz a 7-Irshād a l-Zirā́cī), Hamdān;

At al-Hudaydah, in the Tihāmah Development Authority (al-Hay'ah a 1-cAmmah 7i-Tatw̄̄̄r Tihämah): Mr Mubammad Ahmad Ghālib and Mr Ahmad Qāsim, for their particularly generous assistance; 
At Zabĩd, in the Agricultural Project Centre (a 7-Mashrüc

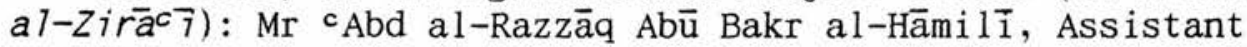
Director;

At Ibb, in the Agricultural office (al-Maktab al-c Amm 7i-al-Zirācah): Mr cAlī al-Nāzilī, Director; Mr Faysal Mubammad Ismācill al-Qafāz, Head of the Ibb Agricultural Co-operative Union; and $\mathrm{Mr}$ Tawf $\overline{\mathrm{iq}}$ al-Maqtarī, Ibb Forestry officer;

At al-Q $\bar{a}^{c}$ idah, in the Agricultural Centre (a)-Mujammac a 7-Zirāc $\overline{7}$ ): Mr ${ }^{c}$ Abd al-Wali ${ }^{c} A b d$ al-Ghanī, Director, and Mr Abmad cAbd al-Rabb, Assistant;

At al-cudayn, in the Agricultural Centre (a 7-Mujammac a 1-Zirāc $\overline{7}$ ): Mr Jābir ${ }^{c}$ Abd al-Malik, Director, who was particularly generous with his time, assistance and hospitality;

At Dhamār, in the Agricultural office (a)-Maktab al-Zirāc $\overline{7}): \mathrm{Mr}$ ${ }^{c}$ Ali ${ }^{c}$ Abd al-Malik, Director.

Finally, I owe an especial debt to the numerous sharecroppers, landowners and other members of the Yemeni public who subnitted good humouredly to my questioning and offered me considerable hospitality in the field. Without their assistance and kindness the research that I have attempted here could not have been carried out.

Nevertheless, I myself am wholly responsible for any faults and omissions which may appear in what follows. 


\section{NOTE ON TRANSLITERATION}

The system adopted in this thesis for transliterating Arabic into Roman characters is in essence that advised by the editors of New Arabian Studies (published by the University of Exeter Press) with very few modifications. In brief, the system as used here is as follows.

\section{Consonants:}

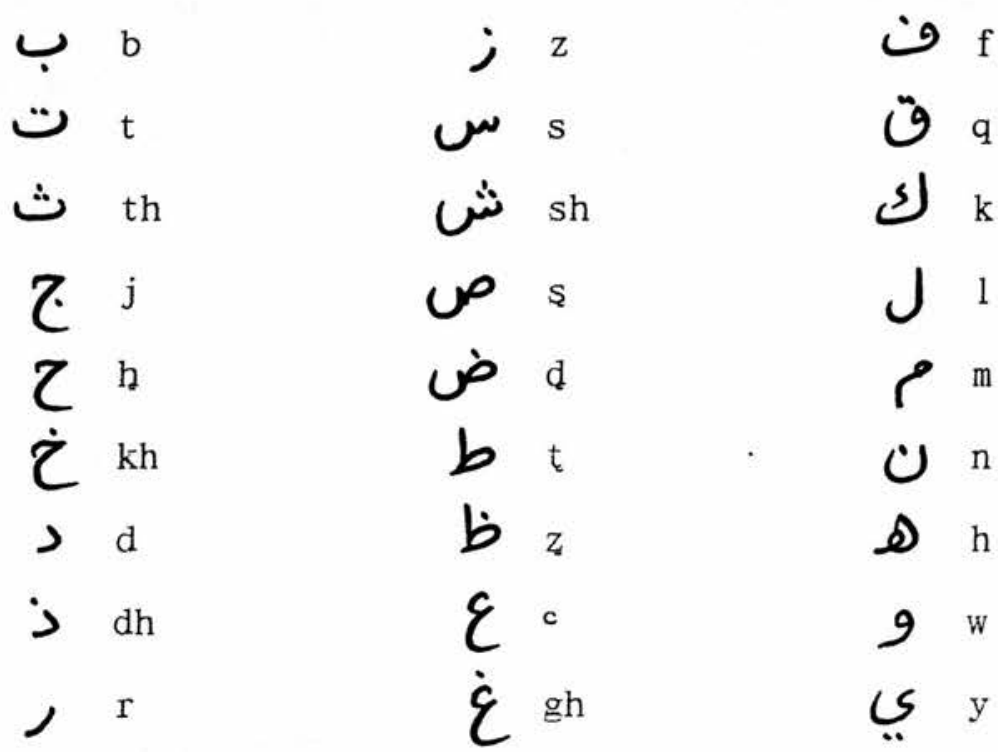

$\ddot{\partial}$ ( $t \bar{a}$ ' marbütah) is normally represented by $h$, but by $t$ when it terminates the first element of an idafah or when full vocalisation is shown.

Hamzah is transliterated with an apostrophe when it is in a medial or final position, but is left untransliterated when initial. For typographical reasons the dot under the emphatic consonants and $h$ has been replaced by an ogonek.

The letter cayn is represented by a superscript "c", rather than a reversed apostrophe".

Vowels and Diphthongs:

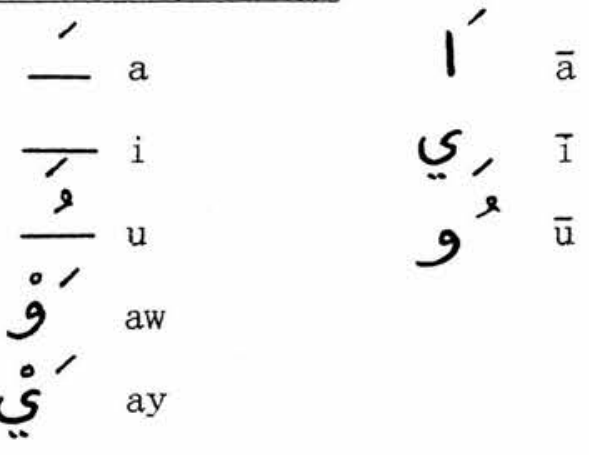


Terminating short vowels indicating case, mood, etc. are not generally shown, even in connected quotations, except quotations from the Hadiths and other sources when the grammar has to be explicitly shown. In such situations, the short final vowels, and tanwin, are shown in superscript: $-\boldsymbol{a}, \boldsymbol{- a n}$, etc.

Nisbah endings are normally written $-\overline{7}$ (masc.) and $-\overline{7} y a h$

(fem.), except when fully vocalised, in which case they are written -iyun, -iyatun, etc.

The letter alif, when acting as the "chair" for a hamzah, is represented by the original vowel of the hamzah, even if in pronunciation this would be elided.

The definite article is always written a7-, even before the "sun letters", and irrespective of any preceding vowel.

Single letter words are linked to the following word with a hyphen. Similarly, pronominal suffixes are generally separated by a hyphen from the word to which they are attached.

So, for example, the sentence:

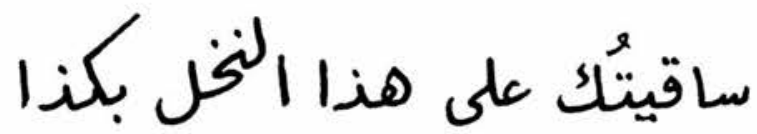

("I (have) engage(d) you in a musāqäh contract over these date-palms in such-and-such a way")

would be transliterated:

Sāqaytu-ka cata hädhā al-nakhl bi-ka-dhä.

Proper Names:

Common place names which have accepted English spellings are not transliterated (so: Medina, rather than al-Madinah; Aden, rather than cAdan). The name of the capital of the Yemen has however been strictly transliterated and written Sanc $^{\mathrm{a}}$ ' throughout.

In personal names which are compound and begin with "cAbd" the elements of the name have been left as separate words: so, for example, ${ }^{c}$ Abd al-Rahmann. The only exception to this is the name ${ }^{c}$ Abdallāh (rather than cAbd Allāh).

"Son of" has been transliterated "bn" (rather than the more usual "b."), except when it forms the first mentioned element of a name, when it is written "Ibn": so, for example, "Abdallāh bn cUmar, but Ibn cumar.

Vernacular:

On a few occasions (in Part II) it has been thought best to reflect (to an extent, at least) Yemeni colloquial speech, rather than at tempt to regularise it to Standard Arabic. So, for example, there will occasionally be shown non-standard changes in vowel quality ( $k i l 7$ for kull; yicallif for yucallif; $\overline{0}$ for the diphthong aw) and other non-standard elements ( shī or shay for shay'; mish for ghayr or laysa). 
Quotations from other Writers:

In quotations taken from other authors, the transliteration of the original is retained.

In the same way, variant English spellings in quotations are also kept. Thus, for example, in the text of this thesis "sharecropper" is spelt as a single word, though quotations from other authors have been included in which the word is hyphenated ("share-cropper") and the hyphenation has been retained in such quotations.

\section{NOTE ON THE METHOD ADOPTED FOR REFERENCING SOURCES}

References to modern literary sources are given in the footnotes of the thesis in the manner for long common in the sciences and social sciences, and increasingly found in certain disciplines in the arts and humanities: that is, by surname of author and year of. publication (so, for example, Smith 1776), and the bibliographic details are to be found in the Bibliography under this reference. In cases where more than one work published in a single year by a given author has been cited, then each is suffixed by a letter (so, for example, Serjeant 1981a, and Serjeant. 1981b).

References to articles in the Encyclopaedia of Islam are given by the surname of the contributor, followed by $E I^{1}$ (for the original edition) or $E I^{2}$ (for the new edition), and the name of the article.

In the case of older Arabic works, manuscripts and other primary sources, the work is referenced in the footnotes by the name by which the author is generally known followed by a shortened form of the title (rather than the date of publication, even where this is known). Thus, for example, the Sifat Jazìrat a ${ }^{-c} A$ Arab by Abū Muhammad al-Hasan bn Ahmad bn Yacqūb al-Hamdānī (d. ca. 336/947), in the edition of Mubammad bn ${ }^{\mathrm{c} A l} \overline{\mathrm{i}}$ al-Akwa ${ }^{\mathrm{C}}$ al-Hawāli and published in Riyād in 1394/1974, is referenced in the footnotes as: al-Hamdān $\overline{1}$ Jazīrat a $1-A r a b$, under which reference the full details will be found in the Bibliography, the definite article in the names of Arabs being ignored for the purposes of alphabetic sorting.

Page numbers are given in the footnotes after the short reference, and are preceded by a colon: so, for example, al-Sharjabi $1990: 150-51$ and 154. Where a volume number is required, it is put in Roman numerals after the colon and before the page number(s): so, for example, Yāqūt Muc jam al-Udabā' :VI, 394-95.

Line numbers, where necessary, are given in subscript immediately after the page number: so, for example, lines 4 to 6 on page 64 of volume 5 of a work would be indicated as :V, 644-6. 


\section{LIST OF CONTENTS}

$\begin{array}{lr} & \text { pag } \\ \text { Abstract } & \text { i } \\ \text { Declaration } & \text { i } \\ \text { Acknowledgements } & \mathrm{v} \\ \text { Note on the Transliteration System Adopted } & \text { vi } \\ \text { Note on the Method Adopted for Referencing Sources } & \text { ix } \\ \text { List of Contents } & \text { xi } \\ \text { List of Figures } & \text { List of Tables }\end{array}$

Chapter 1 : Sources and Context

1.1 Introductory Remarks 2

1.2 Sources 3

1.3 The Yemen : a Contextual Overview 9

PART I : SHARECROPPING AND ITS ISLAMIC DIMENSION

Chapter 2: Sharecropping in Context 25

2.1 Introductory Remarks 26

2.2 The Origins and Rationale of Sharecropping 27

2.3 Islamic Aspects of Sharecropping 43

2.4 Concluding Remarks $\quad 50$

Chapter 3 : Sharecropping in Islamic Law $\quad \cdots \quad 51$

3.1 Introductory Remarks $\quad 52$

3.2 Sharic ah and curf 53

3.3 The Sharecropping Had7ths 64

3.4 The Position Taken by the Islamic Legal Schools 74

3.5 Sharecropping in the Yemeni Civil Code
al-Qanün al-Madan̄ $\overline{7}$

3.6 Concluding Remarks on Sharecropping in Islamic Law 87 
4.1 Introductory Remarks $\quad 91$

4.2 Al-Shāfici on Sharecropping in the Kitāb al-Umm 91

4.3 Al-Nawawi on Sharecropping in the Minhäj al-Tälibīn 101

4. 4 Concluding Remarks on the Shäf $i^{c} \bar{i}$ Position 112

$\begin{array}{ll}\text { Chapter 5 : The Zaydi Position on Sharecropping } & 114\end{array}$

5.1 Introductory Remarks 115

5.2 Ibn al-Murtađ̄ā on Sharecropping in al-Babr al-Zakhkhār 116

5.3 Al-Shawkāni on Sharecropping in the Nayl al-Awtär 138

5.4 Concluding Remarks on the Zaydi Position . 152

PART II : YEMENI SHARECROPPING IN PRACTICE

Chapter 6 : The Current Yemeni Sharecropping Situation and Arrangements 155

6.1 Introductory Remarks $\quad 156$

6.2 The Field Data 156

6.3 The Yemeni Terminology of Sharecropping 163

6.4 The Dominance of Sharecropping in the Yemen 167

$\begin{array}{ll}6.5 \text { Sharing Systems } & 177\end{array}$

6.6 Concluding Remarks on the Current Yemeni Situation 197

Chapter 7 : Sharecropping Animals in the Yemen 202

7.1 Int roductory Remarks 203

7.2 The Yemeni Terminology of Sharecropping Animals 204

7.3 The Incidence of Sharecropping Animals in the Yemen 206

7.4 Analysis of the Systems of Sharecropping Animals
in the Yemen

7.5 Comparison with Analogous Systems 214

7.6 Concluding Remarks on Sharecropping Animals 219 
Chapter 8 : Sharecropping Contracts and Contentions in the Yemeni Context

8.1 Introductory Remarks

8.2 Landlord and Sharecropper: the View from the Field

8.3 Sharecropping Contracts

8.4 Sharecropping Contentions and Pleas

8.5 The Sharecropping Fatwäs of Ibn $\mathrm{Ja}^{\mathrm{c}} \mathrm{ma} n$

1. Glossary of Arabic Terms for Sharecropping Contracts.

2. Arabic Text of the Articles dealing with sharecropping in the Yemeni Civil Code a 7-Qañun a 7-Madañ̄.

3. Arabic Texts of the Yemeni Sharecropping Contracts and Pleas referred to in this thesis.

4. Arabic Text and English Translation of the Báb a1-Musāqāh from the Yemeni Ms. Fatāwä Ibn Jacmän.

(1) Primary Texts

a. Manuscripts

b. Published Texts

(2) Secondary Sources 
page

Table 3.1 Relationships between Lessors and Lessees in Sharecropping Contracts, as viewed by the Yemeni Civil Code

Table 6.1 The Sample Locations of the Present Field Survey 160

Table 6.2 Land and Water Rental : Overall View 172

Table 6.3 Land and Water Rental : Fixed Rent Systems by Source of Water 174

Table 6.4 Land Rental : Details of Fixed Rents 175

Table 6.5 Land and Water Rental : Crop Sharing Systems 178

Table 6.6 Land Rental and Sharing Systems by Source of Water 181

Table 6.7 Land Rental and Sharing Systems : Well Water . 185

Table 6.8 Land Rental and Sharing Systems : Well Water 188

Table 6.9 Sharing Systems by Water Source and by Region 190

Table 6.10 Dominant Sharing Systems by Region 191

Table 6.11 Sharing Systems by Crop 193

Table 6.12 Dominant Sharing Systems by Region by Crop 195

Table 6.13 Dominant Sharing Systems by Crop by Water Source by Region 196

Table 6.14 Sharing Systems by Landowner 198

Table 6.15 Sharing Systems by Landowner - Summary 199

\section{LIST OF FIGURES}

page

Figure 1.1 The Physical Geography of the Yemen 12

Figure 2.1 Schematic Representation of Land Tenure, as viewed from the landowner's standpoint 28

Figure 6.1 The Sample Locations of the Present Field Survey 161

Figure 8.1 Sketch Map of the Area to the West of al-cUdayn 239 


\section{CHAPTER 1 : SOURCES AND CONTEXT}

1.1 Introductory Remarks

1.2 Sources

1.21 Primary Sources

1.22 Secondary Sources

1.3 The Yemen: a Contextual Overview

1.31 A Geographical Sketch

$1.32 \mathrm{Climate}$ and Agriculture

1.33 A Brief Historical Overview

1.34 Administrative Divisions 


\subsection{Introductory Re-arks}

Sharecropping may be defined, briefly, as a system of leasing in which the rent is expressed as a proportion of the harvest, such as a half or a quarter, rather than as an absolute value, such as a certain fixed monetary amount or so many tons or bushels of produce. It is an interesting subject from several points of view. In many areas of the world, including much of the Middle East, it is a major form of land tenure, and for this reason alone it merits study by researchers from a wide variety of disciplines, including historians, economists, anthropologists and specialists in agricultural development. In the Yemen, it is indeed the dominant system by which agricultural land is leased, and it is Yemeni sharecropping which is the focus of this thesis. In the Yemen too, and elsewhere, animals can also be "sharecropped", though there would seem to be very little discussion of this practice in the literature. Nevertheless, despite the fact that sharecropping is so widely found in Islamic countries, a problem arises in Islamic legal theory over the practice. The basis of the problem is that the rent in the lease cannot, by definition, be stated in absolute terms at the time the contract is drawn up, but only in terms of a proportion of the future harvest. That is to say, the absolute amount of the rent will be unknown until the harvest. In general, the theory of Islamic contracts abhors such unknown elements. A major theme of this thesis will be to examine the restrictions that Islamic theory places on the operation of sharecropping and the methods by which the practice can be made acceptable.

The layout of the thesis is as follows. The rest of this chapter will first discuss the sources on which the thesis draws, and then it will present a brief overview of the Yemen as contextual background. The concern of Part I, comprising Chapters 2 to 5 , is 
the discussion of the theoretical basis of sharecropping. In Chapter 2, a short review of sharecropping on the world scale and its rationale is followed by an introduction to the specifically Islamic aspects of the practice. In Chapter 3 the Islamic principles are examined in greater detail. The dozen or so badiths (Traditions) which mention sharecropping and which form the starting point for all Islamic judicial discussion are analysed, and the position adopted on the practice by the main Schools of Islamic law is overviewed, before an appraisal is made of how these views are reflected in the modern Yemeni Civil Code, al-Qanün a1-Madan̄ Chapters 4 and 5 examine the standpoints of, respectively, the Shäfici School and the Zaydi School, these being the two most important Islamic Schools in the Yemen, as they are reflected in the works of four selected jurists.

Part II investigates how sharecropping is carried on in practice in the Yemen. Chapter 6 is a detailed examination of sharecropping land in North Yemen at the present time, while Chapter 7 addresses the practice of sharecropping animals, which is still found in rural areas, even if less so than previously, but which is generally overlooked by investigators. Certainly, the Islamic jurists never pronounce on it. Chapter 8 focuses on the contractual aspects of sharecropping in the Yemen and how any disputes that may arise between the parties to sharecropping contracts are resolved.

\subsection{Sources}

The sources which form the basis of this thesis are drawn from a number of different and sometimes overlapping fields. First, there are works which deal with Islamic law, and within this category, those with explicit reference to the Islamic legal attitude to sharecropping. Then there are studies in the field of customary law, and specifically customary law in the context of Arabia and the Yemen. There are also works on the Yemen of a more general nature which have references to sharecropping or to contextual background information on the country, and which range from travellers' 
descriptions to commissioned reports on the agriculture or rural development of the Yemen.

\subsection{Primary Sources}

Sharecropping has been discussed by Islamic legal authorities from the earliest times. Since there is no direct allusion to sharecropping in the Qur'ān, the point of departure for Islamic legal discussion is always the several badiths (Traditions) which mention the practice, and the original texts of these badiths, as recorded in the two most influential of the "canonical" collections, those of al-Bukhārī (d. 256/870) and Muslim (d. 261/875), are studied in Chapter 3 below. Discussion of sharecropping is to be found in early Arabic works on land tenure and taxation, such as the Kitāb al-Kharāj of Abū Yūsuf 1 (d. 203/818), or the slightly later Kitāb al-Kharāj of Qudāmah (d. 320/932), while practically every work on figh (Islamic jurisprudence) from the time of al-Shāfic $\bar{i}$ (d. 204/820) to the present day has its chapter on sharecropping. Such chapters from four figh works have been chosen for comparative study in this thesis to represent the views of the two main madhhabs (Islamic legal Schools) present in the Yemen. These are the Shäfic $\bar{i}$ works the Kitāb al-Umm of al-Shäf $i^{c} \bar{i}$ himself and the Minhāj al-Tälibinn of al-Nawawi (d. 676/1277), which are the subject of Chapter 4 below, and the Zaydi works al-Bahr al-Zakhkhär of al-Mahdi Ibn al-Murtadā (d. 840/1437) and the Nayl al-Awtār of al-Shawkānī (d. 1250/1834), which are studied in Chapter 5 below. In addition,

1 Abū Yūsuf's Kitāb al-Kharāj was commissioned by the cAbbāsid caliph Hārūn al-Rashīd (reg. 170-193/786-809). Several translations of it into western languages have been made, including those into English by A. Ben Shemesh and Abid Ahmad Ali. (Of these, Ali's version is of ten confusing and in places unintelligible. That by Ben Shemesh is very much clearer.) The section on sharecropping in these translations is to be found in Ben Shemesh :III, 114-117 and Ali :175-181. The equally famous Kitāb a7-Kharāj of Abū Yūsuf's contemporary, Yahyā bn Ādam (d.203/818), makes no reference to sharecropping other than briefly to quote a recommendation concerning the practice attributed to the Umayyad caliph cumar II (bn ${ }^{c}$ Abd al-cAzĩz) (Ben Shemesh translation $1958:$ I, 53). 
the relevant Articles of the modern a1-Qanūn a1-Madan $\overline{7}$ (Civil Code) of the Yemen are also examined in detail (in Chapter 3 below).

Other primary sources which can yield information on attitudes to sharecropping and details of the practice are collections of fatwās (juridical decisions or opinions), and the study of the relevant section from one such Yemeni manuscript collection, so far unpublished, of around 1000/1600 is included in Chapter 8 below ${ }^{2}$. Further materials include records of sharecropping contracts and pleas, and a selection of these from the Yemen is detailed and examined also in Chapter 8. A further source is Arabic treatises on sharecropping, of which a number exist, and one such document, an unpublished Ms. from South Yemen called Kitāb Tash̄̄l al-Mudhākarah bi-Abkām a1-Mukhābarah wa-a1-Muzāracah wa-a1-Mughārasah wa-a 7-Munāsharah by a certain Shāfic $\bar{i}$ shaykh of the Hadramī Bā Kathïr, will be referred to several times throughout this thesis (as the Bā Kathīr Ms. $)^{3}$.

In addition to these literary sources, materials and information collected in the field may also be considered a primary source, and they can moreover be of essential value in interpreting the literary sources. During the course of the research for this thesis North Yemen was visited twice for field study totalling almost four months in 1992 and 1993. The details of the objectives and execution of these field tours, together with their findings, are put forward in Chapters 6 and 7 below.

2 The collection is of the Yemeni Shäficī jurist, Burhān al-Dīn Ibrāhīm bn Muhammad bn Ibrāhīm Ibn Jacmān (d. 1016/1607). The bound Ms. was kindly made available to the present writer by the late R.B. Serjeant and is now the property of the Department of Islamic and Middle Eastern Studies, University of Edinburgh.

3 This Ms. also was made available to the present writer by the kindness of R.B. Serjeant and is now owned by the Department of Islamic and Middle Eastern Studies, University of Edinburgh. 


\subsection{Secondary Sources}

Apart from the many general introductions to Islamic law which are available and of which several will be referred to in the course of this thesis 4 , major modern works which stand out as especially useful in the present context of Islamic sharecropping include Frede Løkkegaard's Islamic Taxation in the Classic Period and Ziaul Haque's Landlord and Peasant in Early Islam, both of which are largely devoted to the question of Islamic land tenancies and sharecropping and the interpretation of the of ten ambiguous early Islamic literary materials 5 . There are numerous slighter studies of aspects of Islamic taxation which include references to sharecropping ${ }^{6}$, especially when state-owned land is being considered, since in such cases a distinction is often difficult to make between, on the one hand, a land tax, such as kharāj or cushr, received by the Islamic state by virtue of its being the state, and, on the other, a rent received from a tenant by the state by virtue of its being the landlord.

Also relevant, since sharecropping inevitably involves contracts, are a number of works specifically on the Islamic law of contract, including S.E. Rayner's Theory of Contracts in Islamic Law and a number of articles by Chefik Chehata ${ }^{7}$. For the detailed study of how the four Sunni legal Schools differ in their attitudes to

4 Essential background introductions to Is lamic law include Schacht 1950; Milliot 1953; Fyzee 1955; Schacht 1964; Coulson 1964; Doi 1984; and Kamali 1991. Seminal texts by the older generation of Islamicists who laid the foundations of the systematic study of Islamic law by European scholars, and which have been cited in this thesis, include Van Den Berg 1896 and Goldziher 1910.

5 Løkkegaard 1950; Haque 1977. D.C. Dennett's (1950). study of early Islamic taxation overlaps in subject matter with Løkkegaard's, though Dennett makes no substantial mention of sharecropping.

6 A great many articles and other works which throw light on Islamic attitudes to land tenure and tenancies have been published over the years. The following have been found of special interest by the present author: Poliak 1936, Poliak 1940, Yusuf 1957, Nadvi 1971 and Düri 1974. Others will be cited in the course of the thesis. 
specific contracts, cAbd al-Rabmān al-Jazīrī's Kitāb al-Fiqh ca Ta a1-Madhāhib a1-arbacah provides an accessible introduction to what is a highly complex subject ${ }^{8}$. Relevant secondary studies of Shīcah positions, and even more so, the specifically Zaydi position, are much thinner on the ground, though the works of R. Strothmann and $\mathrm{w}$. Madelung (on the Zaydīs) and H.M. Tabātabā' $\bar{i}$ (on the Shīcah stance more generally) must be mentioned here ${ }^{9}$.

Works on the foundation and early history of the Zaydi state in the Yemen include those by A.S. Tritton and Cornelius Van Arendonk ${ }^{10}$. Among the many books and articles which have appeared on the customary law of the Yemen, and in particular the supposed dichotomy between the Sharīcah (Islamic law) dispensed by the learned Sadah (the Sayyid descendents of the Prophet) on the one hand, and on the other the curf or täghut (the customary law of the tribes), may be mentioned particularly the recent volume by Paul Dresch11 and the many articles on the subject by R.B. Serjeant and others ${ }^{12}$. On the historical development of Yemeni society more

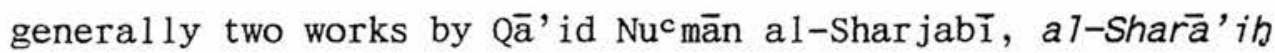

\footnotetext{
7 Rayner 1991; Chehata 1968; Chehata EI , article "cAkd".

8 al-Jazîr 1969 . The sections on sharecropping are in Vol.III, $1-33$.
}

9 See especially Tabātabā' $\bar{i}$ (1983) on the kharāj; also Strothmann $E I^{1}$ article "al-Zaidiyya"; and Madelung $E I^{2}$ article "Imäma". As far as can be seen, there is no discussion anywhere of the specific Zaydi stance on sharecropping outside the primary Zaydi fiqh sources, two of which, as has been said, will be examined in Chapter 5 below.

10 Tritton 1925; Van Arendonk 1960.

11 Dresch 1993.

12 The two recent Variorum editions (Serjeant 1991 amd Serjeant 1995) reprint many of R.B. Serjeant's articles on Yemeni and South Arabian customary law. A small sample of studies on the subject by other authors might include: Rossi 1948; Rathjens 1951; Chelhod 1975; Shāhir 1991; Dostal 1992; al-Sulmî 1993. Others will be cited throughout the thesis. 


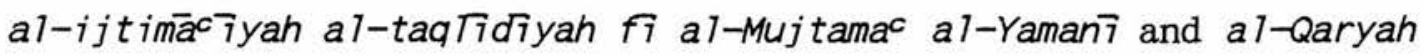
wa-a 7-Dawlah fi a7-Mujtamac a7-Yaman̄ $\overline{7}$, deserve particular mention'13.

Concerning modern field studies of sharecropping in practice, undertaken by specialists from a variety of fields and including economists, anthropologists, historians and geographers, there is by no means any dearth of material, though in the specific case of the Yemen there has been as far as is known only one study devoted wholly to the subject: the UN/FAO agricultural development study of the mid-1980s, which will be examined in Chapter 6 below ${ }^{\mathbf{1 4}}$. A useful background to recent land tenure patterns in the Yemen is given by "Abdallāh Ahmad Nucmān in his Qađayā wa-Mushki Tât a7-Tanmiyah a7-zirāciyyah's. Comparative information from a number of studies from both within and outside the Islamic world will be cited in this thesis. Of special note perhaps, in the context of Islamic countries, are A.K.S. Lambton's study of Iranian agriculture around 195016, and a number of papers written during the first half of the twentieth century which deal specifically with sharecropping in former French colonial North Africal7. More generally, there is a useful collection of studies edited by T.J. Byres which provides much comparative material concerning instances of sharecropping

\footnotetext{
13 al-Sharjabi 1986 and al-Sharjabi 1990.

14 UN 1987. As will be seen in the course of this thesis, sharecropping is the dominant form of land tenancy in the Yemen and it is not therefore surprising that a large number of studies of the Yemen, and particularly the agriculture of the Yemen, mention sharecropping, though generally they do so only in passing.
}

15 Nucmān 1989, especially :84-174.

16 Lambton 1969.

17 These include the important doctoral study of the French colonial lawyer Louis Milliot (1911), and a surprisingly large number of lesser papers produced in the 1930s, mainly by members of the legal fraternity in French North Africa, including those by Georges Rectenwald (1930), J. Abribat (1934), J. Roussier-Théaux (1935), Philippe Noël (1938), Maurice Pouyanne (1939) and Kellal Almenouar (1939). 
around the worldis. Other references will be cited in Chapter 2 below when a world view of sharecropping is presented.

\subsection{The Yenen : a Contextual Overview}

\section{$1.31 \mathrm{~A} \mathrm{Geographical} \mathrm{Sketch}$}

The area known as the Yemen occupies the southwest corner of the Arabian peninsula, a position which has been of great strategic importance historically, with coastlines on both the Red Sea on the west and the Arabian Sea and Indian Ocean on the south and east. Its land boundaries with the Hijāz to the north, with central Arabia to the northeast and with Dhofar (Zafār) and Oman to the east have been historically indeterminate and changeable. Since the merger in May 1990 of the former Yemen Arab Republic (YAR), or North Yemen, with the former People's Democratic Republic of Yemen (PDRY), or South Yemen, most of the historical Yemen has formed one political unit, known now officially as simply the Republic of Yemen (a)-Jumhüriyah a1-Yamanīyah). It is to be remarked however that the historical entity of Yemen is generally taken to include the regions of ${ }^{c}$ Asĩr and Najrān which currently lie within Saudi Arabia to the north. Further, its recent unification is a relatively novel development: most of the country's history has been characterised by political fragmentation.

The area of the present unified republic is impossible to state with accuracy (figures vary from about 156,000 square miles $(405,000$ $\left.\mathrm{km}^{2}\right)$ to as much as 205,000 square miles $\left.\left(530,000 \mathrm{~km}^{2}\right)\right)$, since its eastern desert frontier with Saudi Arabia in the Empty Quarter (a)-Rubca7-KhāT7) has never been agreed in international law and is still open to disputes between the two countries, disputes which have become rancorous in the last couple of decades because of that region's potentiality for petroleum discoveries.

The population of the country similarly can be given in only approximate terms. The latest population census for the North Yemen

Byres (ed.) 1983. 
(the former YAR) which has been obtainable by the present author is that taken in 1986 and for the former PDRY is that of 198819. Those sources give the population of the North Yemen as 9,371,692, and for South Yemen as $2,076,339$, making a total for the unified country of 11,448,031. These figures include 42,512 males and 334,231 females in the North Yemen estimated as "unenumerated for technical and social reasons", and a further 804,007 males and 364,192 females estimated North Yemenis residing outside the country. It can be assumed that most of the North Yemeni males outside the country were working in the Gulf emirates and Saudi Arabia.

To what extent these population figures were accurate even when the censuses were taken is open to debate; but moreover, events since the late 1980s have undoubtedly altered the situation considerably. For several decades the Yemen has had one of the world's highest birth rates, but because of poor rural health resources the high birth rate was largely counteracted by a high infant death rate. However, even in 1990 well over half the population was projected to be under 19 years of age 20 , and continually improving health facilities over recent years will no doubt emphasise even further the youthfulness of the population, and with it increase the economic pressures in providing educational resources and employment prospects to which it gives rise.

Traditionally, levels of unemployment or underemployment have been mitigated by the migration of Yemenis to work abroad, especially, since the Second World War, in the oil-rich Gulf states and Saudi Arabia, though among earlier generations Yemenis of ten went farther

19 The figures to be quoted below are taken from the 1990 Statistical Yearbook (Yemen Republic 1991 :3-4). Although another census was planned for the united Yemen in January 1994 (as announced in The Yemen Times, 8 January 1993, p.2), the published results have unfortunately not become available to the present writer.

20 In $1990,55 \%$ of the urban population and $59 \%$ of the rural population were estimated to be aged between 0 and 18 (Yemen Republic $1991: 4$ ). 
afield - to Southeast Asia and to Europe21. However, the Yemeni government's friendly stance towards Iraq at the time of the invasion of Kuwait in 1990 and the subsequent Gulf War produced the predictable reaction by the Gulf emirates and Saudi Arabia of cutting of $f$ aid to the Yemen and the expulsion of all Yemenis. Since then, the Yemeni currency, the rial (riyäl), once on a par with the Saudi rial, has fallen steadily in value ever since, reflecting a deep malaise in the country's economic health.

The physical geography of the country is the result of two related geological processes: the down-faulting of the Red Sea (as the northwards extension of the East African Rift Valley), and the tilting upwards of the southwest corner of the Arabian massif $\mathbf{2 2}$. As a result, the Yemen forms the highest part of the Arabian peninsula, with several peaks well over 10,000 feet $(3000 \mathrm{~m})$ and culminating in Jabal al-Nabi Shucayb at $12,800(3760 \mathrm{~m})$. The country can be characterised as a huge escarpment, with the scarp facing southwest and deeply dissected by valleys. An appreciation of this structure, shown schematically in Figure 1.1 , is fundamental not only to understanding the variety of the physical regions of the Yemen but also the variations in climate and vegetation, and hence also in agriculture. Figure 1.1 gives also the regional names which will be used throughout this thesis and in particular in Part II which deals specifically with the practical aspects of sharecropping in the Yemen.

\subsection{Climate and Agriculture}

Climatically, the Yemen varies from tropical desert (on the coastal plain of Tihämah and in the southern and eastern parts of the country) through wet sub-tropical regions (principally, the valleys

21 For a study of Yemeni migrant workers in Britain at the turn of the 19th century, for example, see Lawless 1994.

22 This geological process is not yet complete and is the cause of recurrent seismic activity in the country. The most recent serious earthquake occurred in 1982, with its epicentre near Dhamār. 
FIGURE 1.1 : THE PHYSICAL REGIONS OF NORTH YEMEN REFERRED TO IN THIS THESIS

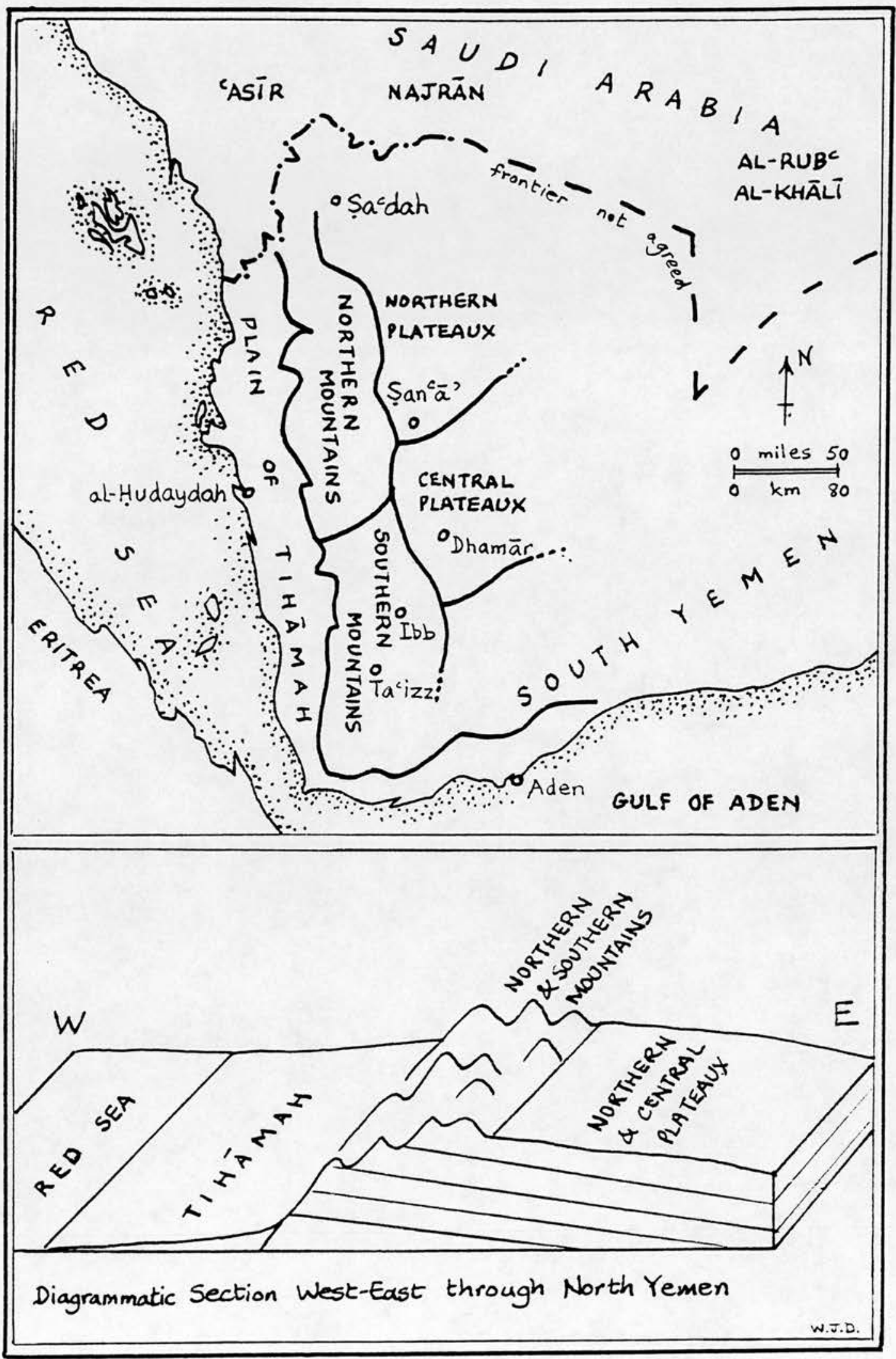


on the western edge of the escarpment) to warm temperate and cool temperate zones (on the high plateaux and in the high mountains). The annual climatic régime for most of the country is governed by the alternation of dry northerly winds in the winter and the monsoon in the spring and summer. The rains from the monsoon occur in two fairly well defined periods, March to May from the eastern monsoon, and July to September from the southwestern monsoon, and although they fall almost wholly in the mountain regions they benefit indirectly in the form of run-off the plain of Tihämah and the otherwise dry valleys of the south, notably the valley of Hadramawt, both in replenishing the water-table and in providing spate water which can then be channelled appropriately for agricultural purposes. Periods of low monsoon rainfall, as occurred in the 1960 s and again for much of the 1980s, therefore affect detrimentally the whole of the Yemen, since the monsoon rainfall is fundamental, directly or indirectly, to all the various irrigation methods found in the country. The sources of agricultural water, the distinction between which will be found later in the thesis to be of analytical use (especially in Chapter 6 when sharing systems are considered in detail), can be considered under four headings:

\section{a) Irrigation from wells:}

Wells tap underground water vertically and depend on the water-table being replenished from rainfall. Traditionally water for agricultural purposes was raised by human or animal power, but most of the old wells which are still working are now equipped with diesel or petrol driven water pumps, while new wells are generally of the tube well kind and are regularly fitted with pumps.

b) Ghayl (pl. ghuyül):

As a general term, a ghayl is simply a surface stream, but its more technical meaning in the Yemen is an artificial channel dug to tap the underground water source using gravity flow, on the same principle as the falaj of Oman and the qanāt of Iran ${ }^{\mathbf{2 3}}$. Typically, the first section of the channel will be 
underground, before it emerges onto the surface and, following closely the contours of the land, is led off to the irrigable areas. Ghay 7 irrigation is typical of the mountain and high plateaux areas of the Yemen.

c) Sayl (pl. suyū7):

In the Yemeni context a say 7 is a surface flood which is caused by sudden rainfall upstream and which can then be channelled artificially by systems of barrages, weirs and sluices to cultivated land. The system is characteristic of especially the piedmont zones of the Tihämah plain and the southern Yemen, where it is particularly well developed $\mathbf{2 4}$.

d) Direct rainfall:

In years of abundant rainfall large areas of the Yemen; and especially the high plateaux, can be cultivated which are not reached by the above irrigation methods. To maximise the effectiveness of the available rain, areas of land several times larger than the cultivated fields, and upstream of them, are cleared of stones. These cleared areas then act as catchment zones to funnel the water to the fields. Some deciduous orchards in the mountains and the high plateaux are reliant solely on rain, but it is cereals particularly which depend on this fluctuating source.

The range of crops grown in the Yemen reflects the wide variety of climatic régimes - from tropical to cool temperate. Of the cereals, sorghum (dhurah ${ }^{25}$ ) is by far the single most important,

23 For a description of the ancient ghayls of Sanc $\bar{a}$, , see Serjeant, Costa and Lewcock $1983: 19-31$. For the qanäts of Iran, see Lambton $E I^{2}$, article "Kanāt". For a discussion of possible origins of the principle of qanäts, see English 1968.

24 For details of how say 7 irrigation is practised in the Yemen, see for example Maktari 1971a and Serjeant 1964.

is The Arabic names given in the following paragraphs for crops are those most commonly heard in the northern Yemen. 
regularly accounting for a half or more of the country's grain production $\mathbf{2 6}$. Several different varieties of sorghum are grown throughout the Yemen (those called locally bamrā, baydă and safrā being the most common) with the exception of the high mountains, where its place is taken by wheat (qamb) and barley (shacī $r$ ), and the hottest parts of Tihāmah and southern Yemen, where millet (dukhn) is substituted. Maize, another important grain crop (known locally as dhurah shämīyah, "Syrian sorghum", or dhurah rūmīyah, "Byzantine sorghum", or simply shäm $\overline{7}$ or $r \bar{u} \overline{7})$, is found very much in the same areas as sorghum.

Concerning fruit, official statistics show, perhaps somewhat surprisingly, that the single most important fruit is grapes (cinab), which account for almost half the fruit production ${ }^{27}$. The high plateaux, and in particular the Sanca' area, are the chief grape producing areas, and while no doubt a considerable part of the harvest is sold as dessert grapes, it is nevertheless likely that most of the production is converted into raisins (zabib). After grapes, bananas (mawz) and papayas (bubāya) are the next most important fruit and are grown in southern Yemen, on the plain of Tihāmah and in the hotter lower valleys of the mountains, while dates (balah), found also in those same areas, are fourth in terms of production. Other tropical and sub-tropical fruit crops include mangoes and various varieties of citrus, including oranges (burtuqā 7 or burtuqān) and lemons ( laymün), both of which seem to have been increasing in production in recent years. In contrast, temperate fruit crops such as apples (tuffâh), pears (ijjās or kummathrā), apricots (barqüq), quinces (safarjal) and peaches (firsik), which are grown on the high plateaux and in the mountains, are

26 The official crop statistics for 1990 and 1991 (the two most recent years for which figures are available to the present writer) show that sorghum accounted for respectively $58 \%$ and $55 \%$ of Yemeni grain production, and covered $60 \%$ of the land devoted to grain (Yemen Republic $1992: 8$ ).

$2745 \%$ of the total fruit tonnage in 1990 and $44 \%$ in 1991 (Yemen Republic $1992: 47-48$ ). 
individually produced in much smaller quantities, though even so they can be locally important crops.

Other crops which are of significance in the local diet are the various pulses and legumes, which are grown throughout Yemen, the variety being chosen according to the climate. In terms of size of production, chickpeas ( Tubiya) are individually by far the most important of this group $\mathbf{2 8}$, though a particularly Yemeni liking for fenugreek (bulbah) should be mentioned since it results in a sizable production of that pulse. Various vegetables and other annual crops, including especially potatoes (batātis), tomatoes (tamātam), onions (basal), peas (catar), a distinctive type of leek (kurräth), and several sorts of melon (including battikh and faqqüz) complete the survey of the most important food crops grown in the Yemen.

In addition, most Yemeni farmers grow fodder crops for their domestic animals. By far the most important of these are sorghum cut green (caTaf dhurah) and alfalfa (qadb or barsīm). Cotton (qutun) is grown in some parts of Tihāmah.

One further crop, not so far mentioned, is of immense social and economic importance in the Yemen, and almost uniquely so in the world. This is the crop called qāt (Catha edulis Forskål), the leaves of which yield a blend of mild narcotics and are chewed, traditionally by a large part of especially the male population, in the afternoons and evenings $\mathbf{2 9}$. At the communal qāt-chewing sessions all subjects from poetry to politics are discussed. The qāt plant grows into a sizable evergreen bush or small tree in the mountain

28 In both 1990 and 1991 chickpeas accounted for $58 \%$ of the Yemeni crop of peas, beans and other pulses (Yemen Republic 1992 :75).

29 For the narcotic chemicals contained in the leaves which are released by chewing and their physiological effects, see Bā Dhīb $1991: 39-40$. For the place of $\overline{q a} t$ in Yemeni society, see Chelhod 1972 and Kennedy 1987. There are a great many names for different varieties and qualities of $\overline{q a} t$, and moreover the names vary considerably from one district to another. The present writer collected 16 such names in Sanca, (dhih ${ }_{7}$ was said to be the best variety and $c$ ans $\overrightarrow{7}$ the second best), and another five names at Ibb, all of which were different from those on the Sanc $\bar{a}$, 1 ist. 
districts and high plateaux of the northern part of the country and the use of the leaves is largely confined to these areas.

The areas from which field information will be particularly drawn in this thesis (especially in Part II) are located in North Yemen, and their characteristics from the points of view of climate, source of agricultural water and main agricultural crops may be summarised as follows:

\section{Northern Mountains:}

- Cool climate on the upper slopes, warm in the valleys;

- Typically ghayl irrigation and rain-fed agriculture, with sayl irrigation and wells in the lower valleys and piedmont areas;

- Deciduous fruit trees and qāt plantations on higher slopes; coffee, bananas, mangoes and other tropical and sub-tropical crops in the valleys.

Northern and Central Plateaux:

- Cool winters and warm summers;

- Rain-fed agriculture and pump wells, with ghayls close to mountain edges;

- Grain crops, and deciduous fruit orchards and $\overline{a a ̄ t}$ plantations.

Southern Mountains:

- Warm to hot climate with high rainfall;

- Typically ghayl irrigation and rain-fed agriculture;

- Deciduous fruit trees and $\overline{q a} t$ plantations on higher slopes; coffee, bananas, mangoes and other tropical and sub-tropical crops in the valleys.

Central Tihāmah:

Hot to very hot summers, and warm winters; humid near the coast in summer;

- Pump well irrigation, with say 7 irrigation especially important towards and within the piedmont zone;

- Dates, bananas, mangoes and other tropical and subtropical fruit crops, with heat-tolerant sorghum varieties and millet as the main grain crops.

\subsection{A Brief Historical Overview}

Known to the Classical world as Arabia Felix, by reason of its great agricultural productivity in contrast to most of the rest of the peninsula, the Yemen in the pre-Islamic period was the centre of a succession of powerful states or kingdoms (if they can be called 
such). The wealth of of these states was based largely on the agricultural fertility, and also on their command of the production of frankincense and their strategic position to control trade routes between the Mediterranean and the Indian Ocean. The rupture of the great dam at Ma'rib, put legendarily in $\mathrm{AD} 525$, is of ten taken to mark the end of the last of these pre-Islamic Yemeni states, that of Himyar, though the breach of the dam is unlikely to have constituted the sole cause nor to have been a single event. Rather, there is archaeological evidence which indicates several breaches and subsequent rebuildings, and it is probable that the influence of the Yemen had been waning ever since the Romans began extending their power into the Red Sea in the first century $\mathrm{AD}$. In the hundred years before its conversion to Islam, the country had been controlled first by the Christian Aksumites (Ethiopians), (whose leader in the Yemen, Abrahā, was in power when the Prophet Muhammad was born ca. $\mathrm{AD} 570$ ), and then by the Persians who briefly made the country a satrapy of the Sasanid Empire. According to Muslim sources, the last Persian governor converted to Islam in $6 / 628$.

After the establishment of Islam in the Yemen the next most important event for the history of the country occurred in 283/896 when there arrived a Hijāzi descendent of ${ }^{c} A l \vec{i}$ through the line of al-Hasan, the Imām Abū al-Husayn Yabyā, called al-Hādī ilā al-Haqq (d. 299/911). He established himself at $\mathrm{Sa}^{\mathrm{c}}$ dah in the north of the country and it was he who introduced Zaydi doctrines and founded the Zaydi state. Most of all the subsequent Zaydī imāms are descendents of his line through his son Ahmad ${ }^{30}$. Although several of the imāms managed to extend Zaydi control southwards, sometimes as far as Zabīd in Tihämah (as in the mid-sixth/mid-twelfth century), different parts of the Yemen were frequently governed, until the twentieth century, by rival rulers and dynasties. The origins of some of the dynasties, such as the Yucfirids (232-387/847-997) with their base first at Shibām-Kawkabān and later at \$ancāa', were local.

30 For the genealogy of al-Hādī see Eagle 1994, including the table on p.117; and also Dresch 1993 especially pp.167-171. 
Others were the result, directly or indirectly, of intervention in Yemeni affairs by Islamic powers to the north, as was the case with the emergence around $439 / 1047$ of the Isma $\bar{c} \bar{i} 1 \bar{i}$ Sulaybid dynasty which for almost a century ruled much of the southern part of the northern Yemen, first from Sanc $\bar{a}$, and then from Dhū Jiblah. More than once a governor sent by an Islamic power based in Iraq or Syria or Egypt usurped its authority and founded a dynasty of his own. Such had already occurred before the arrival of al-Hâdi, when, in the early third/ninth century, Mubammad bn Ziyād was sent to govern the Yemen by the 'Abbāsid caliph al-Ma'mūn (reg. 198-218/813-833) and founded his own albeit short lived dynasty, the Ziyādids, with their capital at Zabid which they founded. A similar event was to occur in the early seventh/thirteenth century when the descendents of a certain ${ }^{c} A 1 \bar{i}$ bn Rasūl, who had arrived in the Yemen from Egypt in the wake of the Ayyūbid take-over of the country, seized power and held it as the Shāficī Rasūlid dynasty with its capitals at $\mathrm{Ta}^{\mathrm{c}} \mathrm{izz}$ and Zabīd for over two centuries from 628/1229 until 858/1453. The interest in the Yemen on the part of the ruling power in the eastern Mediterranean is indeed something of a theme in Yemeni history, as it was to recur in the case of the Ottomans, who occupied varying parts of the country on two occasions: the first from about $945 / 1538$, an occupation which lasted a century, and the second from the mid-thirteenth/mid-nineteenth century which was formally terminated at the end of the First World War.

Any useful "thumbnail sketch" of Yemeni history is therefore difficult if not impossible to make. One important feature does however stand out from at least early Islamic times until the present day. That feature is the division of the country into two broad zones which are conventionally called Upper Yemen (al-Yaman $a 7-a^{c}(a)$ and Lower Yemen (al-Yaman al-asfal). Although the precise boundary between them has fluctuated over the centuries, nevertheless their respective characters have remained. Upper Yemen is the northeastern part of the country, and includes the regions called the Northern Mountains and the Northern Plateaux in this thesis. It is the stronghold of Zaydism, represented by the sädah, 
the sayyid descendents of the Prophet, and its population is predominantly tribal, being the home territory of the two great and ancient tribal "confederations" of Bakīl and Hāshid ${ }^{\mathbf{3} 1}$. It is, moreover, poorer agriculturally than much of Lower Yemen, largely because on the whole it receives much less rain. Lower Yemen, on the other hand, which covers the remainder of the country including the Central Plateaux, the Southern Mountains, the plain of Tihämah and all of the former PDRY, is predominantly Shäfici in terms of religious madhhab (legal School) $\mathbf{3 2}^{\mathbf{2}}$ and the inhabitants have been, historically at least, peasant farmers, rather than tribesmen. The boundary between Upper and Lower Yemen is generally placed somewhere between Sanc $\bar{a}$, and Dhamār. There have been periods in history when a Zaydī imām from Upper Yemen has exercised control over the agriculturally more prosperous Lower Yemen, as in the mid-sixth/mid-twelfth century, and other periods when a ruler from Lower Yemen seized control of $S{ }^{c} \bar{a}$, and the Zaydi areas, pushing the incumbent imām northwards, as happened briefly in the fifth/eleventh century under the Ismacili sulaybids before they took up residence at Dhū Jiblah. Nevertheless, the distinction between Upper Yemen and Lower Yemen has remained as a living concept in the minds of Yemenis.

Since the early tenth/sixteenth century when the use of the Yemeni coffee plant began to be known in Europe, the strategic position of the Yemen at the mouth of the Red Sea has been of

31 The tribal confederations of Bakīl and Hāshid were known at least as far back as the fourth/tenth century, since they are described by the great Yemeni geographer and historian Abū Muhammad al-Hasan al-Hamdānī (d. ca.336/947) (for example, Jazīrat al-cArab :97 and 115, where he is assigning tribes to Bakīl and to Hāshid, and $: 239$, where he is delimiting the areas covered by each of the two confederations). A detailed and penetrative study of the tribes and tribal politics of Upper Yemen, and of the perceived tension between the sädah and the tribesmen, is Dresch 1993.

32 Much of the northern part of Lower Yemen was ruled from $439 / 1047$ for almost a century by the Ismācin $1 \bar{i}$ Sulaybid dynasty, as has been mentioned above, and there is still a small population of Ismācilis in the Manākhah area (to the west of Sanc $\bar{a}$ '). 
interest to the European powers. Before the nineteenth century and the great age of European imperial expansionism the European physical presence in the Yemen was largely confined to trading posts at Mocha (al-Makhā) and Aden. In the nineteenth century however, and particularly after the opening of the Suez Canal in 1869 and the re-emergence of the Red Sea as the major route between Europe and India, the British extended their influence inland from Aden and finally declared Aden a British colony and South Yemen a British protectorate. The British position was consolidated further in the 1930 s by the incorporation of the Hadramawt valley into the Protectorate. Meanwhile, in the mid-nineteenth century, the Ottomans were extending their influence southwards from the Hijāz and inland from the Red Sea coast, until by the beginning of the twentieth century a demarcation agreement between Britain and the Ottoman Empire was required to avoid conflict. The result was the 1904 joint border commission and the frontier the commission mapped between North Yemen and South Yemen was to last until the reunification of 1990 .

The end of the First World War saw the final departure of the Ottomans from the North, which became a formally independent kingdom under the then Zaydī imām, Yabyā bn Mubammad Hamīd al-Dīn, a descendent of the Imām al-Manşūr al-Qāsim (reg. 1598-1620, the founder of the line of the Qāsimīimāms). Although he was never to achieve his desire to annexe either South Yemen or cAsīr and Najrān, the Imām Yabyā did manage to consolidate his control over the whole of the North, including the Shäfic $\bar{i}$ areas. By the end of the Second World War, protest against his autocratic rule, and calls for reform of what remained an essentially medieval government and state, had grown ever stronger within the country. This dissent culminated in Yahyā's assassination in 1948. The reform government which attempted to replace him was however very short lived, and his son Abmad succeeded in taking power as king and imām, with the help of the tribal elements of Upper Yemen. An attempt on Abmad's life in 1955 resulted in his suppression, of ten brutal, of reform-minded Yemenis, and it was not until his death in 1962 that a group of 
military and political reformers was able to strike with a coup d'état. With Egyptian military help, the new Yemeni republican government was able to force Abmad's son Mubammad al-Badr, who had declared himself imām on the death of his father, into the northeast of the country. Despite material assistance from Saudi Arabia, Jordan and Iran in a civil war which lasted most of the rest of the 1960s, Mubammad al-Badr was finally forced into exile and political obscurity in Britain in 1970 when a compromise solution establishing a broadly based republican government was achieved. Muhammad al-Badr died in 1996, so bringing to an end the long (though not unbroken) line of Zaydī imāms which had been founded by al-Hādī in the late third/ninth century. Despite political difficulties in the 1970s (two successive presidents were assassinated in $1977^{\circ}$ and 1978), the Yemen Arab Republic achieved a large degree of stability

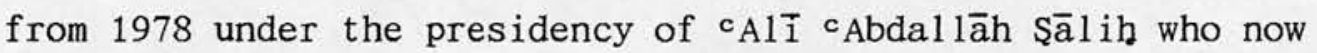
remains as president of the unified Republic of Yemen.

Meanwhile in South Yemen Britain had announced in 1965 its intention to depart within three years. The announcement provoked a bitter feud between rival factions in Aden for control of what would become an independent country. The party which eventually gained the upper hand, the National Liberation Front, moved rapidly to the Marxist left soon after assuming power and renamed the country the People's Democratic Republic of Yemen. Friction followed with North Yemen, which remained committed to a capitalist economy and good relations with the West, culminating in open war in both 1972 and 1979, and any hope that the two Yemens would eventually unite seemed to recede into improbability. However, the 1980 s saw severe personal and ideological conflict emerge within the PDRY which erupted into a brief civil war in 1986. When however Mikhail Gorbachev decided that the Soviet Union would no longer subsidise Communist régimes throughout the world, the PDRY leaders had to accept union with the YAR as the only alternative to national bankruptcy. Negotiations were started in 1989 and the two countries merged officially in May 1990 as the Republic of Yemen. 
So profound have been the events of the last thirty years that no sector of Yemeni life has been left unaffected by them. The agriculture of the country has been influenced as much as other sectors. The fall of the Zaydī imām and the civil war in the North, and the two wars between the North and the South, in the 1970s, the internal political and economic problems in the South in the 1980s, the unification of the North and the South in 1990, and the expulsion of Yemeni workers from the Gulf States and Saudi Arabia in the aftermath of the Iraqi invasion of Kuwait - all these events have produced, in varying degrees, disruption and population movement, and their echoes will be sensed, albeit faintly, in the current sharecropping situation.

\subsection{Administrative Divisions}

Since mention will be made at various points in Part II of this thesis to geographical terms for the various administrative divisions of the country, a brief word must be said about them here.

The system of administrative divisions is not consistent over the whole country. This is not surprising, given the very different recent histories of the former North Yemen and South Yemen. Even in the North, there is no overall uniformity. A complete hierarchy of the traditional administrative divisions and subdivisions might appear as follows, in descending order of size, though some levels in the hierarchy are lacking in some areas. The suggested English terms are of course only approximate.

\begin{tabular}{|c|c|c|}
\hline - & liwä' & "province" or "governorate" \\
\hline- & qada', & "governorate" \\
\hline- & nābiyah & "district" \\
\hline - & cuzlah & "parish" \\
\hline- & mamsa $\bar{a}^{33}$ & "hamlet" \\
\hline
\end{tabular}

33 Cf. mamsiyah in Piamenta 1990-91:466b. 
PART I

SHARECROPPING AND ITS ISLAMIC DIMENSION

$-24-$ 


\section{CHAPTER 2 : SHARECROPPING IN CONTEXT}

\subsection{Introductory Remarks}

2.2 The Origins and Rationale of Sharecropping

2.21 Sharecropping as a System of Agricultural Exploitation

2.22 A Brief World View of Sharecropping

2.23 The Division of the Crop between Landowner and Sharecropper

2.24 Does Sharecropping work to the Benefit or Detriment of the Sharecropper?

2.3 Islamic Aspects of Sharecropping

2.31 Sharecropping as viewed in Islamic Law

2.32 The Islamic Terminology of Sharecropping

2.4 Concluding Remarks 


\section{CHAPTER 2 : SHARECROPPING IN CONTEXT}

"The sharecropper has a sort of partnership and shares both profit and loss with his landlord."

Gaius (2nd Century AD) $\mathbf{1}$

\subsection{Introductory Re-arks}

The purpose of this chapter is twofold. First, in Section 2.2, it will give a brief global survey of sharecropping, including an outline of the features which distinguish it from other forms of agricultural tenure and an indication of its rationale. Since the literature on the subject is so great in volume and so wide-ranging both geographically and temporally the works referred to here must be selective. Deserving special note are perhaps the studies of $\mathrm{J}$. Pratt in Tuscany in the period 1850 to 1950 and A.K.S. Lambton in mid-twentieth century Iran ${ }^{2}$. In addition, T.J. Byres' collection of papers which cover a wide global spectrum has also been referred to $^{3}$. Other references are noted as appropriate throughout the chapter.

The second purpose of this chapter is to show in general terms how Islamic law views sharecropping in order to provide a basis for more detailed discussion in subsequent chapters. Section 2.3 therefore introduces certain fundamental conceptual problems that arise in the Islamic context and the reasons for them, together with an overview of the Arabic terminology concerned in sharecropping

1 Quoted by Ste. Croix $1981: 217$.

2 Pratt 1994; Lambton 1969. Lambton's study is of course not specifically of Iranian sharecropping but rather the agricultural situation on a much broader front. However, because of the great importance of sharecropping in mid-twentieth century Iran, her study is much concerned with the system.

3 Byres (ed.) 1983. 
which, because of its multiplicity, is also listed for reference in Appendix 1.

\subsection{The Origins and Rationale of Sharecropping}

\subsection{Sharecropping as a System of Agricultural Exploitation}

In terms of land tenure (that is to say, how land is held and worked) there are several combinations of choices that may be made to tap the agricultural potential. These are shown diagrammatically as a decision chart in Figure 2.1. First, the owner of the land must decide whether to work the land himself, in which case he will be an owner-occupier; or to allow someone else to work it for him. If the landowner selects the latter possibility, then he has a further decision to make. In the modern world (excluding the use of slaves, serfs or other forms of bonded labour) he is likely to have two choices here: (1) hiring a free labourer to work the land for him and paying the labourer a wage for his service; or (2) leasing the land to a tenant in exchange for the payment of a rent. In either case, the result may be viewed as belonging to one of two basic types, depending on the nature of the wage paid by the landowner or the rent paid by the tenant: fixed wages or rents on the one hand, and sharecropping wages or rents on the other.

In a fixed wage or rent situation the wage or rent is a stipulated value which will be quotable in absolute terms at the time the contract is drawn up (a fixed amount of cash or a fixed weight or volume of crops) and its size will not vary according to the size of the harvest.

In sharecropping on the other hand, the wage or rent is set as a proportion of the as yet unharvested crop (one-half, one-third, etc.). The absolute value of the rent cannot therefore be fixed at the time the contract is drawn up but only after the harvest has been gathered and measured.

Not only is this distinction between fixed wages or rents and sharecropping important in economic and social terms wherever in the world agricultural land is tenanted, but it is also crucially significant in Islamic law as will be shown later (in Section 2.3 below and in Chapter 3). Further, the difference is more important 
FIGURE 2.1 : SCHEMATIC REPRESENTATION OF TYPES OF LAND TENURE as viewed from the landowner's standpoint

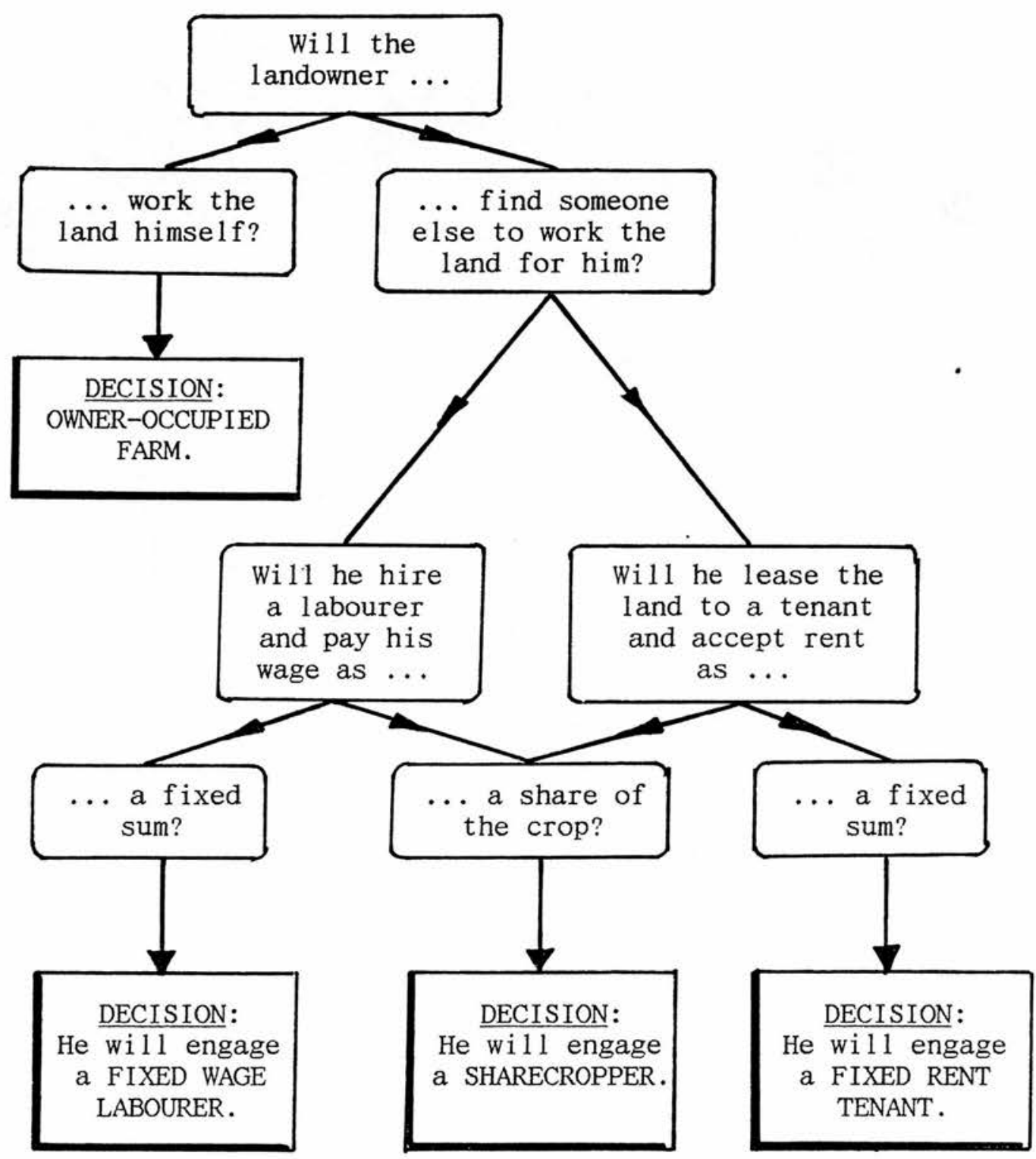


than another distinction of ten made - that between a wage or rent in kind (that is, paid in the crop itself) and a wage or rent in cash (either in advance, or else after the sale of the crop). The fixed wage or rent and the sharecropping wage or rent may both conceivably be paid in either cash or kind, depending on local customs and conditions (for example, how close the nearest market is, or whether there are itinerant merchants), and in any given situation much may depend in fact on the personal preferences of the parties involved.

Sharecropping is undoubtedly an extremely ancient method of agricultural exploitation in its origin and one which continues in many areas of the world down to the present day. The share taken by the landowner is typically one-half of the harvested crop, though in practice his share varies considerably with local conditions as will be shown later in this chapter. In addition, it would seem usual for the landowner to receive from the sharecropper dues and services over and above his stipulated share of the.crop, and this is another aspect which will be taken up below.

The system has attracted a very large literature since Adam Smith, the founder of modern economics, first analysed it critically in the second half of the eighteenth century 4 . As will be seen, many of the studies of the system as it currently operates or has historically operated have shown that the sharecropper is disadvantaged relative to the landlord, and it has attracted criticism from some economists, historians, anthropologists, sociologists and others for this reason. Nevertheless, it has never been conclusively proved that disadvantage to the sharecropper is a result inherent in the system itself, and indeed under certain conditions it can be shown to have theoretical and practical advantages over fixed rent tenure for both the tenant and the landowner.

$4 \quad$ Smith $1776: 391$ et passim. 


\subsection{A Brief World View of Sharecropping}

Sharecropping is known to be of very ancient origin and has been found in widely separated parts of the world. From the historical evidence it is known that forms of sharecropping existed in both Greece and India as early as the fourth century BC and in parts of China it may already have been established as early as the eighth century $\mathrm{BC}^{5}$. Sharecropping certainly existed in the Roman Empire in the second century $\mathrm{AD}$ as colonia partiaria ${ }^{6}$. The system had emerged (or perhaps rather had re-emerged) in France and Italy by the ninth century, while by the thirteenth century it had become the dominant form of agricultural tenancy over much of these two countries as respectively the metayage and mezzadria systems ${ }^{7}$. In the Middle East, the system seems to have been already established in Egypt by the third century $\mathrm{BC}^{\mathbf{s}}$ and in Persia at least by the time of the Sasanid dynasty (226-651 AD $)^{9}$. For the Yemen there appears to be enough evidence to indicate that sharecropping existed well back into the pre-Islamic period when, moreover, much of the local terminology in use today may well have originated $\mathbf{1 0}$.

In more recent periods, sharecropping remained the dominant system in parts of China until the advent of communism in 1947 and in Italy and Turkey until the land reforms of the 1950s in these countries. In large areas of India and elsewhere in Asia and also in much of southern Europe it persists until the present day1. Perhaps most infamously, the system became widespread in the southern states of the USA after the Civil War (1861-65) and lasted

s Byres $1983: 9$ and 11.

6 Ste. Croix $1981: 214$ and 216-17.

$7 \quad$ Pratt 1994 :1 and 31; Duby 1968.

$8 \quad$ Rostovtzeff $1922: 77-79$.

9 Lambton $1969: 206$.

10 al-Sharjabī $1990: 150-51$ and 154-57.

11 Byres $1983: 25-30$. 
until President F.D. Roosevelt's New Deal of the 1930s put an end to its worst injustices $\mathbf{2}$.

Several theories have been put forward by economists and others to explain the reasons why and the courses by which sharecropping emerges and is perpetuated in some regions but is absent or is abandoned in others. For example, the suggestion has been made by some researchers that sharecropping appears as a transitional phase between two other economic systems - for instance, transitional between a slave system and a serf system, or between a slave system and a wage labour system $\mathbf{1 3}$. Another suggestion is that the appearance and disappearance of sharecropping is to be associated with cycles of economic activity. For example, in a persuasive consideration of sharecropping in Turkey during the last seven decades of the ottoman Empire and the first three decades of the Republic, C.. Keyder shows how its cyclic appearance and disappearance can be related to world economic booms and slumps in agricultural commodity prices 14 .

Interesting though these and other theories are, discussion of them 1 ies beyond the scope of this present work. What may be observed here from the large literature on the subject is that there would appear to be a strong tendency for sharecropping to be found in areas or during periods in which there exist either or both of two conditions, and to be absent or to disappear when neither condition is found. These general conditions are: first, the presence of a certain degree of risk to crop yields caused by economic or physical constraints (for example, falling agricultural prices, or land which is agriculturally marginal due to unreliable rainfall or poor soils); and second, a high labour to land ratio (that is, situations where labour is plentiful but agricultural land less so) 15 .

\footnotetext{
12 Conrad 1965; Agee 1965.

13 See for example Byres 1983 :12-13; and Cooper $1985: 146$.

14 Keyder 1983.
} 
Whatever the global applicability of these summary conditions and their analytical utility, it may certainly be noted that the regions in which the system can currently be found or has recently been found are of ten characterised by thin soils and dry-farming techniques in which agricultural yields are particularly sensitive to climatic vagaries. Falling into this category are for example parts of southern France and much of central and southern Italy, and indeed both shores of the Mediterrean area more generally, and additionally the drier grain and cotton lands of the southern states of the USA, the high veld of southern Africa, and much of Iran, Turkey and several other countries in the Middle East, including the Yemen ${ }^{\mathbf{1 6}}$. In contrast, in regions with wetter climate and more predictable crop yields, sharecropping tends not to exist, or has existed only ephemerally: in northwestern Europe for example it seems never to have been found except in isolated areas (Artois, Hainault, and some locations in western Prussia) and then only brief $1 y^{17}$.

15 Both these conditions are consistent with, for example, Keyder's analysis of sharecropping cycles in late Ottoman and early Republican Turkey (see Keyder 1983 especially 132 and 137). Further, both also apply in the case of the Yemen, the subject specifically of Part II of this thesis.

16 There have been a great many detailed studies of sharecropping carried out by modern researchers specialised in a variety of fields. The following is a very small sample: Pratt 1994 (central Italy); Gill 1983 (Tuscany); Conrad 1965, Reid 1973 and Mandle 1983 (all concerning the southern states of the USA); Keegan 1983 (the South African high veld); Lambton 1969 (the agricultural situation, including sharecropping, in Iran in the mid-twentieth century);

Keyder 1983 (late Ottoman and early Republican Turkey).; Halim 1983 (western Malaysia); Cooper 1983 and, in greater detail, Cooper 1988 (both dealing with Bengal in the period 1930-1950); and Sharma and Drèze 1990 (Palanpur, Northern Gujerat, India). Several other studies deal specifically with former French colonial North Africa, including Milliot 1911, Rectenwald 1930, Abribat 1934,

Roussier-Théaux 1935, and Noël 1938, and discussion of some aspects of their works will be taken up later. Some facets of the case of the Yemen are the subject of especially Part II of this thesis.

17 Byres $1983: 17-18$. 
Nevertheless, the above statements are by no means intended as deterministic, and it can perhaps be misleading to generalise about the reasons for the presence or absence of sharecropping as a system of agricultural tenancy over such a vast temporal and geographical range. Further, it must be noted that there exist several different forms of sharecropping, depending on the amount of investment contributed by the sharecropper (a subject which will be taken up below in Sections 2.23 and 2.24), or on the type of crop involved (whether it is, for example, an annual arable crop, or a perennial tree crop, a point which will also be shown to be of significance later in this thesis). In short, it may well be that no explanatory model to fit all occurrences can be devised and that beyond a few broad generalities each incidence is the result of unique economic and physical circumstances. In any case, such questions, though fascinating, are not the concern of this study. Discussion here will instead centre rather on two issues regarding the characteristics of the system which are commonly remarked on by researchers. Both have to do essentially with the relationship between the landowner and the sharecropper, and both are of importance in the case of the Yemen as will be shown in Part II of this thesis. The first concerns the proportions of the crop accruing to the landowner on the one hand and the sharecropper on the other. The second concerns the extent to which the sharecropping system may be beneficial or detrimental to the sharecropper.

\subsection{The Division of the Crop between Landowner and Sharecropper}

In sharecropping systems the most common division of the crop between landowner and sharecropper is theoretically on.a 50:50 basis, as is suggested by the terms for the system in French and Italian métayage and mezzadria, and also the terms in other European languages in areas where the system has been historically found (Halbpacht and helftwinning in medieval western Prussia and the Netherlands respectively)18. This equal division is by no means universally applied however, even in the areas where such terms implying a half-share are used. In certain areas at certain times 
the landlord's share of the crop may be only one-quarter or less, or as high as three-quarters or even more. In point of fact, a large variety of proportions have been reported throughout the world and over the centuries according to differences in local environmental and economic conditions. Thus, for example, Georges Duby, speaking of the situation in southern France in the twelfth and thirteenth centuries, says that the metayage contract

gave the master a widely differing share in the produce according to the quality of the soil and the condition of the 'farmer': sometimes it gave him two-thirds of the crop, more often a half or a third, but occasionally much less, especially when the soil was not very fertile. In 1338 the Provençal Hospitallers were unable to find a peasant willing to take [and] farm certain land on their demesne, even when he was offered nineteen-twentieths of the produce to keep for himself.19

So - here was a landlord offering the sharecropping peasant practically the whole crop, and yet the peasant was free to reject the offer! This point should be borne in mind in later discussion (Section 2.24 below) when the fairness or otherwise of the system to the sharecropper is examined.

In practice, the division of the harvest between landowner and sharecropper may be achieved in one of several ways. The allocation of the landowner's share may be made after the crop has been gathered and measured by dividing appropriately the total volume or weight of the harvest. If the crop is a cash crop grown for sale in a local market or to itinerant merchants, the landlord's share may be allocated by dividing the cash value received from the sale. Alternatively, the division may be made during the gathering process itself, by allocating every $n$th unit (every $n$th sheaf of corn or every $n$th basket of fruit, and so on) to the landowner. So for example in a 50:50 arrangement every second unit gathered would be

18 In the French and Italian terms the meta- and the mezza- are ultimately from the Latin medietas, "half". Similarly, Halb and helft mean "half" in respectively German and Dutch.

19 Duby $1968: 275$. 
assigned to the landowner, while if the landowner's share is one-third of the crop, then he would be allocated every third unit. Another method is for the landlord and sharecropper to take their respective shares from different parts of the land, a method apparently practised in the Hijāz at the birth of Islam and one which will be referred to later when the Islamic Traditions which deal with sharecropping are examined (Chapter 3, Section 3.3, below).

One factor which undoubtedly affects the proportions of the two parties' shares is the nature of the physical environment of climate and, as Duby indicates in the quotation cited above, the fertility of the soils. Generally speaking, the more marginal the area is for crop production the larger will be the share allotted to the sharecropper. The rationale behind this is presumably that in areas where soils are poor or where water resources are either small or highly variable from year to year, agricultural yields will be low either every year or in a large proportion of the years. A sharecropper in such an area will not survive very long if year after year too large a part of each harvest is given up to the landlord. Although the landlord will profit in the short term by taking an unsustainably large a share for himself, in the long run the failure of his sharecroppers will harm him too.

Another important influence which can affect the amount of the crop the sharecropper actually receives is the way in which any government tax due on the crop is deducted. In some systems of sharecropping the tax due is deducted from the total harvest before division into shares. This is equivalent to each party contributing to the tax payment a share proportional to his share of the harvest. In other systems, either the landowner or the sharecropper will be liable to pay the tax on the total harvest from his respective share. Clearly, the method by which the tax is deducted can affect the real shares received by the two parties as opposed to their theoretical shares.

A more fundamental influence on the size of the shares received by the landlord on the one hand and the sharecropper on the other concerns the provision of the agricultural inputs. The size of each 
share of the harvest can sometimes be seen to reflect the respective contributions supplied by the two parties. In the case of grain land these inputs may include the seed, the water, and the animals, tools and machinery needed for ploughing the soil and harvesting the crop and then transporting it and threshing it, and so on. In the case of perennial plantings, such as orchard trees or grape-vines, the ownership of the trees or shrubs can be considered an input: they may belong either to the landowner or sometimes to the sharecropper. The landowner may provide, in addition to the land itself, any or none of these other inputs, while the sharecropper, in addition to his labour and possibly also the labour of his family, may similarly provide any or none. Generally speaking, the more of these inputs either party contributes the larger will be his share of the harvest, though there is rarely any exact or regular relationship in practice.

An extremely systematised application of this principle has been recorded by A.K.S. Lambton in her study of agricultural tenure in mid-twentieth century Iran. In Lambton's words,

Traditionally, five elements are taken into account in dividing the crop: land, water, draught animals, seed, labour: theoretically one share [of the crop] is allotted to each element and goes to whoever provides that element.20

So, for example, a landlord who provides only the land and the water (that is, two of the five inputs) would theoretically receive two-fifths of the crop, leaving the remaining three-fifths for the sharecropper who will have supplied the other three inputs of draught animals, seed and labour. Conversely, a sharecropper who supplies nothing but his labour would receive only one-fifth of the crop, leaving four-fifths for the landlord.

As Lambton indicates however this neat pattern is hardly more than a theoretical abstraction, and she found in her fieldwork that in practice a huge variety of different systems of crop division existed in Persia, including 50:50 division and instances where the 
landlord's share is as much as two-thirds or four-fifths, even when he supplied no more than the land and the seed $\mathbf{2 1}$. Moreover, she points out that the sharecropper must typically provide a number of extra dues and services for the landlord over and above the latter's contracted share of the crop. These extra dues and services might include transporting the landlord's share to the granary, labour service in building roads and irrigation works, "gifts" of various produce (clarified butter, hens, eggs, and so forth), and a number of other unremunerated services or goods 22 .

Both in the variety of crop division systems and in the sharecropper's provision of a range of additional services and goods to his landlord, Lambton's Persia is by no means exceptional. In fact, it would seem to be something of a rule that a sharecropper is bound to render the landlord various extra obligations, whether these are stipulated in the contract or not. Such for example was the case with the sharecroppers of central. Italy before 1950, as reported by $\mathrm{J}$. Pratt in his detailed study of them. In addition to handing over half of the agricultural product of their labour, there existed "a range of other possible obligations: to provide accommodation or hospitality when [the landlord] visited, or to supply some days' labour each year on road building and estate maintenance, a practice similar to corvée labour"23. Such "supplementary" services are also found in Yemeni sharecropping, though, it would appear, they are not particularly onerous, as will be seen (Chapter 7, Section 7.42, and Chapter 8, Section 8.2). In any case, as will also be shown, it is surprisingly difficult to determine in the Yemen what, in practice, are the contractual obligations properly speaking, in contrast to such "supplementary" burdens.

21 Lambton $1969: 308-09$.

22 Ibid. $: 330$.

23 Pratt $1994: 41$ 


\subsection{Does Sharecropping work to the Benefit or Detriment of the}

\section{Sharecropper?}

Among modern researchers views on the economic and social benefits of exploiting agricultural resources by the sharecropping system have tended to polarise between those who, like the eighteenth century founder of modern economics Adam Smith, hold that the system benefits the landowners as the dominant class to the detriment of the sharecroppers' interests $\mathbf{2 4}$, and those who, like the nineteenth century philosopher John Stuart Mill, maintain that, under certain historical, economic and geographical circumstances, the system is the best geared to benefit all parties involved 25 .

Those observers and analysts of sharecropping who are generally supportive of the system have viewed sharecropping agreements as partnerships arrived at by bargaining and as such the system is claimed to benefit both parties ${ }^{\mathbf{2 6}}$. In the idealised system the landlord supplies the land and the sharecropper the labour, and both are equally recompensed with a half share of the harvest. If the harvest is large, the rent will be large. If the harvest is small or non-existent, then the sharecropper will have to hand over only a small rent or no rent at all. As Gaius put it in the second century $\mathrm{AD}$, "the sharecropper [colonus partiarius] has a sort of partnership and shares both profit and loss with his landlord"27.

Such is the theory, at any rate - though as has been shown above this model situation of reward proportional to input by no means always applies. Many critics of sharecropping have indeed pointed out that even if the system is viewed as a partnership it is

\section{Smith $1776: 391$.}

25 Mill $1848: 185$. Pratt (1994:49) makes the interesting point that this polarisation of views of sharecropping as on the one hand the bane of the peasantry and on the other their beneficiary was neatly reflected in the context of Italy during the Fascist period.

26 See for example, Mandle (1993:123) who summarises this view (though rejecting it).

27 Quoted by Ste. Croix $1981: 217$. 
rare for it to be other than a partnership between grossly unequal partners $\mathbf{2 8}$.

There is no doubt that many studies of sharecropping show that landlords do hold the dominant position in the relationship and their dominance is frequently to the detriment of the economic and social interests of the sharecropper, sometimes to the extent of total dependence. G.E.M. de Ste. Croix points out that although in a poor harvest a sharecropper would have to give his landlord only a small rent, he would also himself go short of food, and if poor harvests continued over several years, he would eventually become as much at the mercy of his landlord as would a fixed-rent tenant who defaults ${ }^{29}$. Ste. Croix is speaking here in the context of the Roman Empire of the second century AD - but his observation might be applied much more generally. In medieval France, for example, Duby describes sharecroppers' hardship very similarly: because of lack of security of tenure, he says, sharecropping.contracts "seem to have held the defenceless peasantry ... tightly in a net of economic dependence"30. Lambton, in the context of mid-twentieth century Persia, has equally observed that "in general the scales are weighted in favour of the [landlord], and little or no protection is afforded to the tenant"31. Adrienne Cooper's studies of sharecroppers in Bengal between 1930 and 1950 likewise explain their problems as a fault of the system ${ }^{32}$. Many other similar examples of what some writers have referred to as the "web of dependence" suffered by sharecroppers might be quoted for many regions in many periods. Perhaps most vividly of all, at least in the consciousness of the English-speaking world, largely as a result of the highly graphic fictional writings of American authors of the interwar

\footnotetext{
28 Cf. Byres $1983: 13$.

29 Ste. Croix $1981: 217$.

30 Duby $1968: 327$.

31 Lambton $1969: 306$.

32 Cooper 1983 and 1988.
} 
years, such as John Steinbeck and Erskine Caldwe11, and also the powerful photo-documentary work of James Agee and Walker Evans, is the plight of the sharecroppers of the southern states of the USA in the $1920 \mathrm{~s}$ and $1930 \mathrm{~s}^{\mathbf{3 3}}$.

The argument of the critics of sharecropping, then, would seem to be that because there are many examples of sharecroppers in situations of great hardship and dependence on their landlords, the reason must be the sharecropping system itself. It is surely easy to see the flaw in this assertion. While it is undeniable that some sharecroppers in certain areas and at certain times have been exploited by ruthless landlords, it is by no means proved that this is the result of the sharecropping system per se. There are at least four reasons for supposing this. First, many examples could be quoted of dependent and indebted agricultural workers under agricultural systems other than sharecropping. Second, the vagaries of climate and of economic cycles must be held responsible in many cases of sharecropper misery. Third, under a sharecropping system the interests of the landlord and of the sharecropper are to a large extent interdependent. Fourth, examples exist where the relationship between the landowner and the sharecropper is truly a mutually beneficial partnership in practice as well as in theory.

That sharecropping as a system does not necessarily work wholly to the detriment of the sharecropper is brought out clearly by $\mathrm{J}$. Pratt in his detailed study already cited of the mezzadria of central Italy before the land reforms of $1950^{34}$. Although agricultural life under the system was physically hard for the sharecropper and his family, the sharecropper existed materially on a much better level than certain other societal strata, notably the

33 See, for example, John Steinbeck's novel The Grapes of Wrath, in which the Joad family, reduced to sharecroppers on land they once owned, are finally driven from Oklahoma by mechanisation; and several of the novels, stories and plays of Erskine Caldwe11, such as Tobacco Road, set among sharecroppers in Georgia. Also: Agee (with Evans) 1965 passim.; and Conrad 1965 passim.

34 Pratt 1994. 
day-labourer. It is true that the landlord took half of almost all the produce of the farm and might exact also a range of other obligations from the sharecroppers, such as labour for estate maintenance, but the produce of the kitchen garden and the farmyard at least were exempt from the 50:50 division and belonged wholly to the farmer's family3s. The day-labourer, on the other hand, had no such exempt reserve.

Further, again according to Pratt, although the Tuscan landlords as a whole attempted deliberately to exclude sharecroppers from the market and the money economy, and although, moreover, they could and sometimes did evict their sharecropping tenants, nevertheless sharecroppers equally had the power to seek out better landlords and better farms. Given that much of the work on farms consisted of investments such as terracing, planting olives and vines, "work which would generate no product for five or ten years, ... the long term productivity of the farm.therefore depended on the investment of labour by the share-croppers, and this was of ten stipulated in the contract, but it was unlikely to be performed satisfactorily if there was constant uncertainty about the tenancy"36. To avoid evicting his sharecroppers if at all possible was therefore in the landlord's own interests.

Additionally, one may note instances of sharecroppers with a certain autonomy of choice, which could not exist if dependency and indebtedness were inherent in the system. An historical instance has already been quoted above of landowners in thirteenth and early fourteenth century Provence receiving a much smaller share of the crop on infertile land and the ability of peasants to refuse to take on sharecropping tenancies when it did not suit them, even when they could keep all but one-twentieth of the crop ${ }^{37}$. Similarly, Pratt

\footnotetext{
35 Ibid. : 41 .

36 Ibid. :39.

37 Duby $1968: 275$.
} 
observes in the context of central Italy that "share-croppers could and did seek out other landlords to find better farms"38.

In short, Pratt's picture of the condition of sharecroppers in central Italy in the late nineteenth and early twentieth century resembles far more that of the Provençal sharecroppers of around $1300 \mathrm{AD}$ than it does, for example, Agee's portrayal of the sharecroppers of the southern states of the USA during the same period ${ }^{39}$. In other words, there would seem to be no reason to suppose that the sharecropping system is inherently disadvantageous to agricultural tenants' interests. Indeed, given fair landlords, the system conceivably has considerable advantages for tenant farmers in areas where for climatic, pedological, economic or other reasons the level of risk in farming is high. This is because a sharecropping rent, unlike a fixed rent, is by definition directly related to the size of the harvest. A small harvest will mean that the tenant pays only a small rent. A complete failure of the harvest will mean that he pays no rent at all. The system is therefore potentially fairer to the tenant's interests in areas of fluctuating harvests.

In fact, this is a very idealised picture, and in practice other factors come into play. Ste. Croix, for example, observes that the size of a tenant's holding would be important in whether he survived or not during difficult years of poor or non-existant harvests, and he rightly points out that this is of ten overlooked 40. Further, as will seen in due course (in Section 2.3 below, and in Chapter 4), if the sharecropping contract is viewed not as one in which the sharecropper is leasing the land as a tenant, but rather as one in which the landowner is hiring the sharecropper as a

38 Pratt $1994: 35$.

39 In any case, the primary causes of the plight of American sharecroppers in the interwar period can be more satisfactorily explained as the result of a fatal combination of drought, soil exhaustion and world economic slump, rather than wicked landlords and merchants.

40 Ste. Croix $1981: 217$. 
labourer (as the Shäfici jurists regard $i t$ ), then in a year when the harvest fails the sharecropper will be placed in the invidious position of having worked for no wage. In any case, even the ideal situation depends on landlords acting fairly towards their sharecropping tenants. Although of course fair-minded landlords can never be guaranteed, proscribing practices which are potentially unfair to sharecroppers would seem to be a central concern of how Islamic law regulates sharecropping contracts, and it is this matter which will now be considered.

\subsection{Islanic Aspects of Sharecropping}

\subsection{Sharecropping as viewed in Is lamic LaW}

Sharecropping in the Islamic context has been the subject of a large literature over the centuries. From a random glance over the multitude of works of figh it would seem that practically every Islamic authority has pronounced on the matter. This has been largely because the system has always been problematic in Islam since it involves gharar (risk) and can lead to ribā (unjustified profit), both of which are forbidden in Islamic contract law. Examples of what the writers of figh have to say about sharecropping of particular relevance to the Yemen are studied in Chapters 4 and 5. This Section is, however, only an introductory overview of some of the relevant concerns.

A major instance of gharar in a contract is the failure to specify certain essential elements, and as a result of such omission the contract would be annulled by being declared fasid (defective) or batil (invalid), depending on the precise nature of the omission. The elements requiring specification vary with the type of contract. Bayc contracts (contracts of sale) for example that do.not specify the date on which payment for goods will be made are theoretically invalid, since such contracts could lead to speculation and rib $\bar{a}^{\mathbf{1}}$. So too are bayc contracts and ijärah contracts (contracts of renting, hiring or leasing) which involve goods that are not present at the time the contract is concluded, since this is another of the requirements to make a sale or leasing contract valid: the object of the sale or lease must be present and therefore visible and open for 
inspection. Examples of such invalid contracts are the sale of $\mathrm{fish}$ or other animals which have not yet been caught, and the contract called babl al-bablah, the sale of an animal while it is still in the womb42.

As will be mentioned below, sharecropping contracts are frequently regarded as ijärah contracts and ostensibly they may be construed as invalid on both the above counts according to the strict interpretation of the rules for ijarah contracts: the date of payment cannot be precisely specified in the contract since the date of the harvest will not be exactly known; and the exact value of the rent cannot be specified since the harvested crop is not present at the time the contract is made.

Sharecropping is indeed most frequently considered a form of ijarah in Islamic law and is often defined in the following terms: Renting land for a part of its produce, or hiring a labourer for part of the produce of the land43. That is to say, if a sharecropping contract is considered as a type of ijārah it can be viewed in two different ways, depending on what it is that is being rented or hired. If the contract is seen as the sharecropper leasing the land as a tenant, then the landowner's share of the crop

41 There are, it is true, a few exceptions where jurists allow a limited degree of indetermination in bayc contracts, but in general, in Rayner's words, "Any degree whatsoever of uncertainty in the payment of the price renders the contract null and void" (Rayner $1991: 357)$.

\section{Rayner 1991 :153; Khan 1976 :III, 199 n.1.}

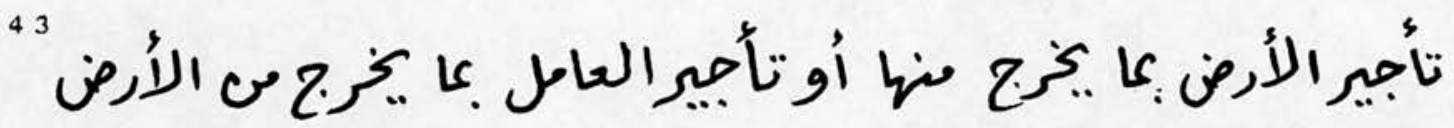

ta'j̄ir al-ard bi-mā yakhruj min-hā aw ta'j̄ir al-cāmil bi-mā yakhruj min al-ard ("The leasing of land against its produce, or the hiring of a labourer against the produce of the land"). This is the Shāfic $\bar{i}$ formulation as given by al-Jaz $\bar{i} \mathbf{i}$ (1969:17), though in fact as will be discussed later (Chapter 4, Section 4.2, below) al-Shäficī's Kitäb al-Umm regards as valid only the second possibility: that is, the hiring of a labourer. However, the Yemeni Civil Code (a 7 -Qanūn a 1-Yaman̄i) makes a more subtle three-part distinction, as will be shown in Chapter 3 (Section 3.5). 
will be the ujrah (rent). If on the other hand the contract is viewed as the landowner hiring the sharecropper as a labourer, then the latter's share of the crop will be his ajr (wages). In both cases however the rent or wage is defined in terms of a share of what is produced from the land at the time of the harvest - which, by definition, cannot be known at the time the contract is drawn up, and hence the problematic gharar.

Alternatively, some jurists (notably those of the Māliki School) have viewed sharecropping as a sharikah or shirk (partnership contract) on the grounds that it resembles mudarabah (a profit-sharing commercial partnership in which one partner supplies the capital and the other the time, skill and effort to invest it), in which, contrary to the rules governing ijarah, there is no alternative but to specify the share of the profit (ribb) taken by each partner as a proportional share since a ribb which is defined as an absolute sum or quantity is not possible in a mudarabah contract44. If sharecropping contracts are so viewed, then the problem of undefined terms and objects not present disappears. However, other difficulties still remain which have prevented even Mālikī jurists from unanimously allowing sharecropping in all circumstances.

These points will be taken up in more detail in Chapter 3 and elsewhere in this thesis. To conclude this brief overview of the Islamic aspects of sharecropping it is appropriate now to introduce the somewhat complex Arabic terminology of the subject and in so doing to explain the distinctions Islamic law makes in regarding different types of sharecropping.

\subsection{The Islamic Terminology of Sharecropping}

There exists a complex profusion of Arabic terms for Islamic sharecropping contracts. Part of the terminological multiplicity results from the fact that early Islamic sources distinguished between sharecropping in different agricultural situations, such as

44 Schacht $1964: 156-57$; Wakin $E I^{2}$, article "Mudaraba". 
sown grain land on the one hand and tree crops which require irrigation on the other, or between different contracts according to which party supplies which of the necessary inputs such as seed corn and agricultural implements. Another part of the reason is regional differences. Regional differences as they concern the Yemen will be considered later (Chapter 6, Section 6.3, and Chapter 7, Section $7.2)$. The purpose of this present section is to give an overview of the terminology found in the Islamic legal sources.

In the literary sources the most commonly found terms for sharecropping contracts are mukhābarah, muzāracah, mughārasah and musāqāh. Mukhäbarah is a general term found in the Had̄iths (Traditions of the Prophet) and in the legal works. Its etymology is not entirely clear. It is of ten assumed that it derives from the place name Khaybar, since it was at this oasis, some 90 miles (145 $\mathrm{km}$ ) north of Medina, that the Prophet entered into a crop-sharing agreement with the resident Jews $\mathbf{4 5}$. Other. suggestions are that it

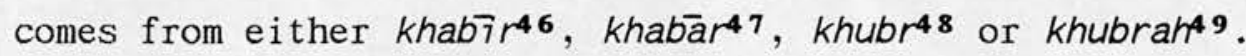

Muzāracah (the Form III verbal noun from the same root as zarc which means either sowing, or grain, or cultivation especially though not necessarily with grain) is also found in the legal texts and although its etymology refers specifically to sharecropping contracts on land sown annually, the term is also used to mean

45 For the historical event see Veccia Vaglieri $E I^{2}$, article "Khaybar". The relevant badīths are: al-Bukhārî Had̄̄ths 521, 522, 524, 531; these are discussed later (Chapter 3, Section 3.3, below).

46 According to several sources khabīr (lit. expert) in this context means akkär, barrāth, zarrāac and fal Tah, that is, ploughman or cultivator, and the derivation of mukhäbarah from it has been suggested by al-Shawkāni (Nayl al-Awtār :VI, 8), and by the author of the Bā Kathīr Ms. $(: 220)$. See also Lane 1863-93:695b, under the Form III verb khābara.

47 Khabār, soft land. The derivation of mukhäbarah from it has been suggested by al-Shawkānī (Nayl al-Awtār :VI, 8), and by al-Jazîrî (1969:III, 3). Cf. Lane 1863-93:696b.

48 Khubr, a share. Al-Shawkānī (Nayl al-Awtār :VI, 8) suggests this as the derivation of mukhäbarah. Cf. Lane 1863-93:696a. 
sharecropping more generally as a synonym for mukhäbarah. A distinction between muzāracah and mukhäbarah is sometimes made, though not universally held: mukhäbarah is where the tenant's share is defined as the crop from a specific plot of the landso. Alternatively, another distinction is of ten made between mukhäbarah and muzäracah on the basis of which party provides the seed: in the former the seed is provided by the cultivator, while in the latter it is supplied by the landowner ${ }^{\mathbf{1}}$. For example, the Shāfic $i_{\overline{1}}$ al-Nawawi makes precisely this distinction in the Minhäj al-Tălibīn, a work to be studied in more detail in Chapter 4 below $5 \mathbf{2}$, and according to the Shäfici author of the Bā Kathīr Ms. Abmad bn Hanbal distinguished the two contracts in the same ways3. Such a distinction is not however held by other authorities, including al-Shāfic $i^{\overline{1}}$ himself $f^{54}$, a fact commented on by al-Shawkāni $\bar{i}^{55}$.

Both mughārasah and musāqāh are also widely found legal terms. Mughärasah (the verbal noun of the Form III verb from the same root as ghars, plants and planting, especially in relation to trees and shrubs $^{56}$ ) is sharecropping in land planted with perennial crops

49 Serjeant (1967:62 n.110) tentatively connects this term khubrah with mukhäbarah. According to him, a khubrah is a basket-cover placed over ripening dates. In the present writer's opinion, it would seem unlikely that the widespread and well-known term mukhäbarah should derive from a local Hadrami word such as this. One or other of the derivations suggested by al-Shawkāni and others, as indicated in the previous notes above, would seem much more likely.

50 For example, the Yemeni Civil Code a1-Qanūn a 7-Madan $\overline{7}$, which will be studied in detail in Chapter 3 (Section 3.5), defines mukhäbarah in this way (a)-Qanün a 7-Madanī, Explanatory Note to Article 739).

51 al-Jazīri 1969 :III, 5; Siddiqi 1976 :III, 815 fn.1998. Cf. Van Den Berg 1896 :93 n.3. See also Young EI , article "Muzäraca".

s2 Al-Nawawī Minhāj al-Tălibīn, :II, 1434-6.

53 Bā Kathīr Ms. : 82-4,

54 Al-Shāficī Kitāb al-Umm (:VII, 101; Bāb al-Muzāracah).

55 Al-Shawkānī Nayl al-Awtār (:VI, 8-9). 
(typically orchards and vineyards), while musāqāh (the verbal noun of the Form III verb from the same root as saqy, irrigation) is sharecropping on land requiring irrigation (typically date-palm plantations). Both therefore involve perennial crops and are thus clearly distinguished from the mukhäbarah and muzāracah proper (though as has been noted above, both these latter terms are sometimes used more generally to include all kinds of sharecropping).

The essential distinction between mughärasah and musāqāh is usually that in the mugharasah contract, the sharecropper is leasing the landowner's land as a tenant, whereas in the musāqāh, the landowner is hiring the services of a sharecropper as a labourer. This may seem an unnecessary theoretical distinction, and in practice it of ten counts for little: so much so, in fact, that the ottoman Land Code combines both these contracts together, ignoring any valid differences there might be between them ${ }^{57}$. One practical distinction is often made however which is of importance. In the musāqāh, the trees almost invariably belong to the landowner and in most cases will already be mature enough to bear fruit when the contract is made. In the mugharasah however, it will of ten be the responsibility of the sharecropping tenant not only to plant the trees he is to tend (hence such a tenant is frequently referred to as the ghäris, the planter), but also to supply them as saplings (ghars, pl. aghräs) or palm-shoots (fas̄ilah, pl. fasä'i7; maqlac, pl. maqālic; $\operatorname{wad} \bar{y} y$ (collective)). The operation of this kind of mughärasah contract will be mentioned again in greater detail in the context of Mālikî North Africa in Chapter 3 (Section 3.4).

\footnotetext{
56 Cf. Lane :2247a-b, entry $g h-r-s$.

s7 Roussier-Théaux (1935:132 n.4) makes this same point. For an annotated English translation of the text of the Ottoman Land Code and related Ottoman land legislation, see Hooper 1933 (especially 369-371 for Articles 1431-1440 on the muzäracah, and Articles 1441-1448 on sharecropping involving trees, with no distinction between mughärasah and musāqāh). Other annotated translations include Fisher 1919, and Ongeley 1892.
} 
Two further terms - mubāqalah and kirā' al-ard-deserve mention since they are also used in the collections of badiths and the early legal works of the jurists in the context of sharecropping.

Mubāqalah (the verbal noun of the Form III verb from the same root as baq7, field) has two different meanings in the bad7 ths and the early legal works. First, the term can mean the sale of grain while it is still growing, a type of transaction which Islam prohibited, and this is the meaning usually attributed to it in modern legal works 58 . Second, it is also used to mean simply a sharecropping contract involving grain growing land, in which case it is the same as muzāracah's . Although the term has therefore two different meanings, they are related in that both involve a commodity which is the object of a contract but which is not present at the time the contract is concluded - that is to say, an example of a gharar (risk) transaction which Islamic law tries to avoid, as has already been mentioned (Section 2.31 above).

Kirä' al-ard (sometimes iktirä' al-ard) is literally the renting or leasing of land and is not therefore specifically sharecropping. Nevertheless, in the context of the earliest Muslims, as narrated in the sharecropping bad7 ths to be discussed later (Chapter 3 Section 3.3), the term can usually be construed as sharecropping since it would seem that this was a common method of renting out land at that time.

There are many other terms for sharecropping which have either a specific meaning or a local usage, and many of them would seem not to appear in the standard published lexical sources. Several more will be encountered in the course of this thesis, especially when

58 Cf. Rayner $1991: 160$. In this sense it is virtually the same as the equally prohibited pre-Islamic contract of muzäbanah, the only difference being that the latter involves dates rather than grain.

s 9 For example, Muslim Had7 ths 3732 and 3756; cf. Siddiqi 1976 :III, 815 n.1998. See also Nayl al-Awtär :VI, 9, where al-Shawkāni quotes the view of al-Shäfici from his Kitāb al-Umm (which is discussed later (Chapter 4, Section 4.2, below)). 
the specifically Yemeni aspects of the subject are examined in Part II. For reference, all terms known from the legal literature and also from specifically Yemeni oral sources have been collected in Appendix 1. These number eighteen for sharecropping land (excluding multiple variants from the same root), and a further four (plus variants) for sharecropping animals.

\subsection{Concluding Remarks}

The concern of this chapter has been first, to place sharecropping in its global context, and second, to point to some specifically Islamic aspects of the system, and in particular the difficulties which arise in Islamic law concerning the prohibition of gharar in contracts. The historical origin of the problem as it concerns sharecropping is to be found largely in the ambiguous character of the badiths (the Traditions which relay the Sunnah, or practice, of the Prophet) which deal with sharecropping, and these bad7 ths will be examined in detail in the next chapter (Chapter 3).

Whatever the theoretical legal positions however, it is often maintained that curf (custom) rather than the Sharj $\overline{7}^{c}$ ah dominates public and private dealings not only in southwest Arabia but also much more widely in the Islamic world60. The importance of curf in this context and its relationship to both the Sharjcah and to modern statutory legislation will therefore be expanded in the next chapter.

60 For example, Serjeant 1955a; Serjeant 1979; Maktari 1971a;

Løkkegaard 1950 :174; Schacht EI Article "Bayc" : $1112 \mathrm{~b}$. 


\section{CHAPTER $3:$ SHARECROPPING IN ISLAMIC LAW}

3.1 Introductory Remarks

3.2 Sharīcah and curf

3.21 Islamic Law and the Ușü al-Fiah

3.22 Relationships between the Shar $\bar{i}^{c}$ ah and Customary Law

(a) curf and cAdah

(b) The Validity of curf in the Shar $\bar{i}^{c}$ ah

3.23 Islamic Theory and Islamic Practice

3.3 The Sharecropping Hadiths

3.31 The Had7ths in Question

3.32 The Had7ths Permitting Sharecropping

3.33 The Hadiths Prohibiting Sharecropping

(a) The Rāfic Hadjiths

(b) The Prohibitory Had7ths without Context

3.4 The Position Taken by the Islamic Legal Schools

3.5 Sharecropping in the Yemeni Civil Code al-Qanūn a 1-Madan̄

3.51 The Articles on the Mughärasah (733 to 736)

3.52 The Articles on the Muzäracah (737 to 741)

3.53 The Articles on the Musāqāh ( 742 to 743 )

3.54 The Article Relevant to Both the Muzäracah and the Musāạāh (744)

3.55 Observations on the Sharecropping Articles in a 7-Qãün a 1-Madan̄

3.6 Concluding Remarks on Sharecropping in Islamic Law

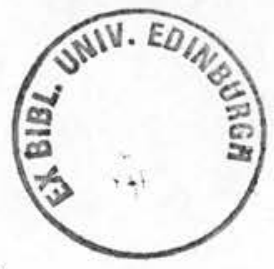


"On peut dire qu'il y a presque autant de doctrines professées que d'auteurs ayant écrit sur la question [de la muzāracah]."

Louis Milliot 1

\subsection{Introductory Renarks}

Although the focus of this thesis is the theory and practice of sharecropping in the Yemen, some basic concepts of Islamic law and their terminology must first be reviewed, since certain legal terms will recur later on. These concern the distinctive nature of that law and particularly the position of custom relative to it. The chapter therefore begins with a brief discussion, in Section 3.2, on Islamic law and the sources from which it derives, and then on its relationship with customary law. The Section concludes with some remarks on theory and practice in the context of Islamic jurisprudence. In this Section the material discussed is derived mainly from modern secondary sources since the discussion is intended only as a necessary background to the main subject of the thesis.

The chapter continues, in Section 3.3, with a detailed examination of the Primary Source in which all Islamic legal discussion on sharecropping is rooted, namely, the dozen or so Traditions ( adiths) which refer to the practice.

Section 3.4 is a brief overview of the positions taken on sharecropping by the various Islamic legal Schools (madhhab, p1. madhāhib) as a preparation in Chapters 4 and 5 for a detailed study of the stances of specifically the Shäfici $\bar{i}$ and Zaydi Madhhabs, these being the Islamic Schools which are of particular importance in the Yemen.

$1 \quad$ Milliot $1911: 17$. 
The chapter ends, in Section 3.5, with a discussion of the relevant Articles in the modern Yemeni Civil Code (a)-Qänūn a)-Madan $\overline{7}$ ) which deal with sharecropping.

\subsection{Shar $\overline{7}^{c}$ ah and $c$ Urf}

\subsection{Islamic law and the Ușü al-Fiah}

Islamic law differs from modern western conceptions of law in several respects, one of the most major of which is the fact that for Muslims the Islamic law, the Shar $\overline{7}^{c} a h$, is based on immutable divine revelation (waby, sharc), the embodiment of which is the Qur'ān. The Qur'ān is the first Primary Source (așl, pl. ușül) of the law for all Muslims. The Sunnah, the practice of the Prophet, is the second Primary Source and has been passed down through the generations in the form of badiths (Traditions) the two most prestigious and reliable collections of which are those of Mubammad bn Ismācīl al-Bukhārī (d. 256/870) and Muslim bn al-Hajjāj (d.

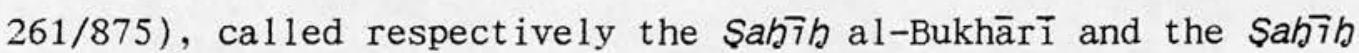
Muslim. These two Primary Sources (the Qur'ān and the Sunnah) are often referred to as the nass (the text or letter) of Islamic law.

The means to interpret these two Primary Sources are ijmāc (the unanimous consensus of qualified Muslim scholars) and qiyas (analogical deduction). Since the work of Muhammad bn Idris al-Shäfici (d. 204/820), the eponym of the Islamic School of Law, Muslims have been generally united in regarding $i j m \bar{a}^{c}$ as the Third Source of the law and qiyas as the Fourth Source 2 .

It must be mentioned that other terms are used by some Schools to mean qiyās, notably by some $\operatorname{Sh}^{c}{ }^{c}$ ah sects and by the Ibādiyah.

2 It should be noted that some contemporary Muslim scholars, for example, M.H. Kamali (1991 :xix) prefer, when writing in English, to reserve the term "source" for the Qur'an and the Sunnah and call ijmāc and qiyās "proofs" in order to mark their secondary and subservient status, since neither $i j \overline{m a}^{c}$ nor qiyas can override explicit instructions of the Qur'ān or the Sunnah. However, Kamali is by no means uniform or consistent in this, and the present writer has considered it adequate for his purposes to refer to these four bases of Islamic law by the term "source" or "principle", both of which may translate the Arabic as 7. 
The term ra'y was freely used in the ancient Islamic Schools to mean individual reasoning of both an arbitrary and a systematic nature without distinction ${ }^{3}$, though for most Muslims nowadays ra'y can mean only arbitrary opinion and has little place in law. The term caq 7 (reason, rationality) is or has been also similarly employed, with the same qualifications. A further term, ijtihād (literally, endeavour, effort, and more technically, striving to produce legal judgments on the basis of the interpretation of the Sources), was held by al-Shāfic $\bar{i}$ to be synonymous with qiyăs ${ }^{4}$, though in the analysis of most Islamic jurists this term tends to be employed with a wider signification, encompassing not only qiyās but also some subsidiary principles (such as istishāb and ististah) which will be discussed briefly below.

These four principles or sources (the Qur'ān, the Sunnah, ijmāc and qiyās), as systematized by al-Shäfici ${ }_{i}$, form then the four basic ușü al-fiah, the sources or principles of the Sharīcah, as accepted by most Muslims. The term uşül al-fiqh however also means the procedures applied to these sources to deduce the fiqh, the rules of the law. In clarifying the difference between figh and uşu 7 al-figh, which are often confused in translation, Kamali helpfully gives the analogy of the relationship of grammar to a language and of logic to philosophys. The ušut al-fiah provide the correct criteria to deduce the rules, and the figh is the corpus of the rules so deduced, that is, the law itself. As such, the two terms refer to two connected though separate disciplines within Islamic law, and for a scholar to be called a faq̄in (pl. fuqahā'), a specialist in fiqh, he must be expert not only in knowing the rules and how to apply them, but also in knowing their origin in the sources, the ušut.

3 See, for example, Doi $1984: 77-78$.

4 Schacht 1950 :99.

$5 \quad$ Kamali $1991: 2$. 
Although in general al-Shāficī's system of four principles or sources has been adopted by the Islamic Schools, some have made certain modifications. Most Islamic jurists add ijtihäd to the usür al-figh, though others, notably al-Shäf $i_{\bar{i}} \bar{i}$ himself, have held that ijtihād and qiyās are synonymous, as has been mentioned above. It would seem to the present writer more helpful to consider ijtihäd as the combination of qiyas and other more subsidiary principles, which is in fact the position adopted by many Muslims 6 .

One of these subsidiary sources of Islamic law, which is accepted to some extent by all the main Schools of figh, is the principle of istişāb, the presumption that a situation known to exist in the past continues to exist until there is evidence to the contrary. A.R.I. Doi provides several examples of this principle, one of which is that innocence of an accused is presumed until guilt is proved. Another of his examples, which has relevance in the field of land ownership, is that valid title deeds are presumed by a judge to be valid until the contrary is proved ${ }^{7}$.

Most of the Schools of Islamic law, though with the notable exception of the Shāfici ${ }^{i}$ School, admit also the principle of istibsān (discretionary preference) as a subsidiary source of the law. A similar principle is called ististah (judging good), or masāil mursalah ([public] welfare set loose [from the texts]), or simply maslabah ([public] welfare), according to the terminology of the different Schools. The idea behind all these terms is that discretion may be applied in judgments to overrule strict qiyas in cases where the public interest would thereby be benefited, with the proviso that such judgment, in order to be valid, does not contradict the explicit instructions of the Qur'ān, the Sunnah or $i j m \bar{a}^{c}$. Doi provides seven examples of cases where istibsān has tempered strict qiyas and been permitted in the interest of public welfare ${ }^{8}$. One of these, bayc bi-al-wafa' (sale subject to a future redemption) is a type of mortgage permitted exceptionally because of

\footnotetext{
$6 \quad$ Cf. Kamali 1991 :xv.

7 Doi 1984 :83-84.
} 
public need, even though it involves gharar (risk), a concept which has already been noted in the previous chapter (Section 2.3) as a major problem in Islamic sharecropping contracts.

A further subsidiary principle, that of curf (custom), is in practice recognised by all the main Schools of figh when it does not contradict the Shar $\overline{1}^{c} a h$, though the extent to which it is an independent source of Islamic law is subject to different opinions. A more detailed examination of $c^{c} u r f$ and how it relates to the rest of the Shar $\bar{i}^{c}$ ah will be taken up below (Section 3.22). Here it need be noted only that where the curf in question is sabih (that is, where it does not conflict with the explicit instructions of the Sharīcah), it can, like istibsān, be used to overrule strict qiyās, and also that curf may be fasid (that is, in conflict with the Shar $\left.\bar{i}^{c} a h\right)$ and yet nevertheless be practised by the people ${ }^{9}$ - in which case theory has become separated from practice.

In summary, then, it is possible to regard Islamic law as comprising three components or types of law: first, divinely ordained law (the Qur'ān and the Sunnah); second, discretionary law ( $i j m \bar{a}$ ', qiyās and for many Muslims the other types of ijtihād); and third, customary law.

\subsection{Relationships between the Shar $\bar{i}^{c}$ ah and Customary Law}

(a) curf and cAdah:

There are two terms in Arabic which are used in the general sense of custom: curf (literally, what is known, from the root verb carafa, to know; pl. $a^{c} \overline{r a ̄ f}$ ), and cādah (pl.cāāat, from the root verb $c^{c} \bar{a} d a$, to return, and therefore some action which is returned to habitually). Some authorities distinguish between them. The $\operatorname{Ta}^{j} j$ al-cArüs records that some say that $c^{-}$adah refers to actions, while curf concerns words'o. According to certain Islamic jurists on the

8 Doi $1984: 82-83$.

$9 \quad$ Kamali $1991: 293$; Schacht $1964: 62$

10 Tajj a7-cArüs (1965-), entry cādah (:VIII, 443b3-6). 
other hand, curf is "the collective practice of a large number of people", while cădah is the habit of only individuals or groups 11 . In the hands of other authorities, curf is of ten translated into English as customary law, while cādah is rendered as habit with no legal implications, an important distinction reminiscent of that made clearly in a much broader context by the great English legal philosopher H.L.A. Hart12. If this distinction is adhered to, then it is curf which concerns the present discussion, rather than cädah. More frequently however, the two terms are not distinguished in Islamic law, since most authorities would seem to use curf and cādah interchangeably 13. Here, curf and its plural $a^{c}$ räf will be used to mean customary law in the Islamic context.

(b) The validity of curf in the Sharicah

The question of the extent to which curf is a valid principle in the Shar $\bar{i}^{c}$ ah requires some discussion. The issue is clouded since some authorities imply that curf stands in opposition to the Sharicah, whereas others include curf among the possible ușül (sources or principles) of the Sharicah. The theoretical position of the Shāfic $\bar{i}$ Madhhab (School of Law) is to reject curf as a valid as 7 . In contrast, the Hanafis and the Mālikis in particular give weight to curf in theory as well as in practice14. The Zaydis too, in line with their generally pragmatic approach to legal questions, tend to accept curf as a valid as 7 .

Attitudes taken by modern writers on Islamic law concerning the extent to which curf is or is not part of the Sharicah also vary. For example, A.R.I. Doi includes curf, albeit briefly, in his list of the sources of Islamic law, though only in cases which are not at

\section{Kamali $1991: 283$.}

12 Hart $1961: 54-56$. In Hart's legal scheme, a habit is an element of convergent social behaviour which attracts no censure if it is breached; a custom in contrast is prescriptive and its breach leads to criticism or sanctions from other members of society.
13 See for example Maktari 1971a:5.
14 Rayner $1991: 33$. 
variance with the Qur'ān and the Sunnah ${ }^{15}$. M.H. Kamali discusses curf in some detail and similarly designates it as a valid and authoritative source of law when it does not contravene the principles of the Shar $\bar{i}^{c} a h^{\mathbf{1 6}}$. In contrast, Joseph Schacht saw a conflict between ${ }^{c}$ urf and Shar $\bar{i}^{c}$ ah in actual practice ${ }^{17}$ and stated explicitly that Islamic law "ignores custom as an official source"18. A.M.A. Maktari, in the introduction to his impressive study of the irrigation of Lahj, reports similarly that in theory Shāfic $\bar{i}$ jurists reject curf as a source of Islamic law, or even as a complement to the Shar $\bar{i}^{c} a h$, but it is clear from his study that irrigation in Shäfici Lahj is governed by the rules of local customary law19. Many of R.B. Serjeant's works concern the. interplay between curf and Shar $\bar{i}^{c} a h$, especially in southern Yemen but also more generally2o. Other researchers have found a conflict between curf and Shar $\bar{i}^{c}$ ah in the modern context, as for example A. Layish and A. Shmueli in their examination of Judaean bedouin legal documents $\mathbf{2 1}$.

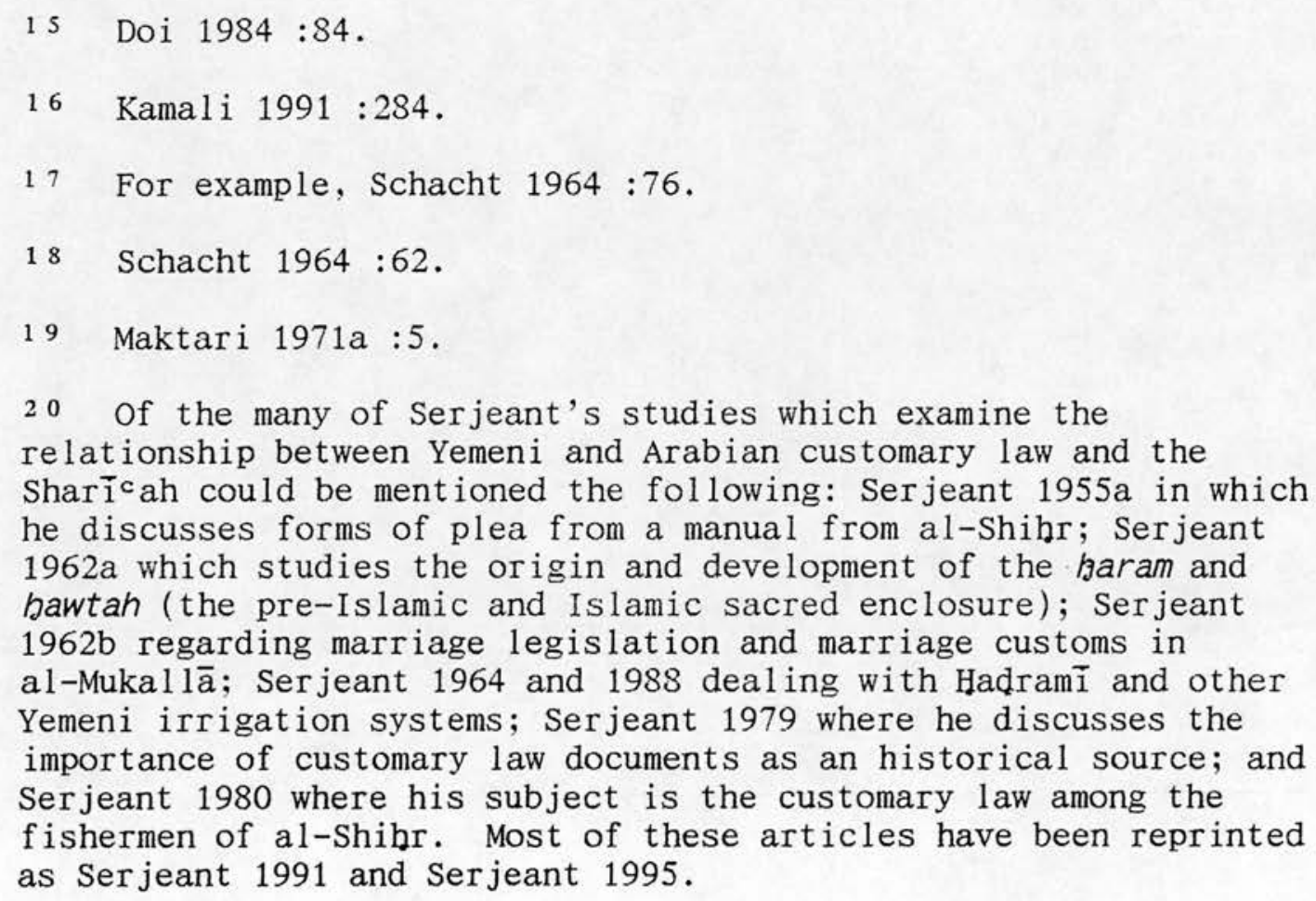


Whatever the theoretical view of a particular School or authority may be, it is indisputable that curf greatly influenced Islamic law in its earliest development and has continued to influence it down to the present day. Whether and to what extent curf should be considered in opposition to the Shar $\bar{i}^{c}$ ah or as one of its legitimate usū 7 are questions best left to the legal theorist, since in the practical world they would seem to be at best unhelpful and at worst misleading.

Some customs are not in conflict with any Shar $\bar{i}^{c}$ ah principles and are said to be sabīh. These are by definition as much part of the Shar $\bar{i}^{c}$ ah as other subsidiary sources for example of istibsān and maslabah inasfar as they are used as bases for judgments by. Islamic judges, though admittedly to a varying extent by different schools. Indeed, Kamali points out that curf and maslabah are closely related concepts in that they seldom conflict and each serves as "a means for the realisation of public welfare and the prevention of hardship to people"22, and further, both, like istibsān, can override strict aiyās even though qiyās is otherwise of a higher level of authority as a source of the Sharicah.

In the case of other customs there is clear evidence that they do conflict with the Shar $\bar{i}^{c} a h$, and are therefore fasid. One example here is the disinheritance of females as practised by certain bedouin tribes. Even curf fasid however can be regarded as law, insofar as it practised and accepted as such by the majority of a population, since to be law neither legislative enactment nor judicial recognition is an essential requirement, though of course such curf fasid would not be part of the Islamic law.

The conditions under which curf may be valid in Islamic law have been summarised by Kamali23. According to him, in order for curf to be used as a basis for legal decisions in Islam, it must meet the following conditions. The basic requirement is that it must be "reasonable and acceptable to people of sound nature" and

\footnotetext{
22 Kamali 1991 :291.

23 Kamali $1991: 286-288$.
} 
that it therefore should be free of prejudice and corruption. Kamali then adds the following four requirements: (1) it must be observably dominant in the society; (2) it must be in existence at the time of a transaction; (3) it must not contravene what is stipulated in a contractual agreement (which generally takes precedence); and (4) it must not violate the nass - that is to say, the definitive principle of the law as embodied in the Qur'ān and the Sunnah. Even when these conditions are met however and a particular curf in question is regarded as curf sabīh (that is, curf in which there is no conflict with the Shar $\left.\bar{i}^{c} a h\right)$, many Islamic jurists do not accept it as an independent proof in its own right, however important it may be as a guiding principle in practice ${ }^{\mathbf{2 4}}$.

Even though curf is not regarded by some as an official source of Islamic law, there is no doubt that judgments based on it can be valid, and indeed as Joseph Schacht and others have made clear, the Shar $\bar{i}^{c}$ ah itself, both in its original formation and in its subsequent development, owes much to customary law 25 . It is undeniable that curf has been extremely influential in the development of the Shar $\bar{i}^{c} a h$, and was indeed a major agency in its original formation. Because of both the divinely revealed nature of Islamic law and the fact that the perspective of historical development was theoretically lacking in Islamic jurisprudence, the debt which the Shar $\bar{i}^{c}$ ah owes to curf was largely ignored until the work of the Western analysts and especially Schacht. Building on the work of Ignaz Goldziher, Schacht concluded that the Shar $\bar{i}^{c}$ ah was the outcome of a complex historical process based in the curf of the pre-Islamic Arabs and of the peoples they conquered26. Although subsequent analysts and commentators have quarrelled with the

\footnotetext{
24 See for example, Maktari 1971a:5.

$2 \mathrm{~s}$ Schacht 1964 :12ff. and passim.; Chelhod 1986, especially 20-23.
}

26 Schacht 1964 :passim., esp. Chh. 2, 3 and 4 . Whatever might be the theoretical position of the classical view, Islamic legal history does exist, as Coulson (1964:4) says. 
details of Schacht's argument it is generally accepted that the roots of Islamic jurisprudence are pre-Islamic Arabian curf. J. Chelhod, for example, believes Schacht overstated his case and gave too little emphasis to the changes that Islam brought, but he nevetheless concludes that "il est indéniable en effet que le substrat antéislamique tient une place importante dans le nouveau système religieux"27.

\subsection{Is lamic theory and Islamic practice}

Several consequences flow from the fact that the Islamic law is a revealed law. In its theoretical classical conception, the Shar $\vec{i}^{c} a h$ has no notion of any historical development, and changing social conditions and requirements have in theory no legitimate role in deciding Islamic law. In practice, however, as has been pointed out above, istibsān, istișâh or maslabah can commute the strict application of qiyas where public interest.would thereby be served. curf similarly can override qiyass where there are already established customs. In either case qiyās can be overturned only where the Shar $\bar{i}^{c}$ ah would not be expressly contradicted - though, of course, since those subsidiary principles together with qiyass have themselves played a leading part in forming the Shar $\vec{i}^{c} a h$ into a comprehensive and consistent body of law, and since moreover the various Schools differ on many points of practical detail within that body of law, it may well be wondered what the phrase "only where the Shar $\bar{i}^{c}$ ah would not be expressly contradicted" actually means.

For this reason it has been frequently claimed, following the analyses of Ignaz Goldziher and then Joseph Schacht, that there is a gulf between the theoretical ideal and actual practice in Islam; or in other words, that there is inherent in Islamic law a distinction between what might be considered the ideal, theoretical doctrine, and the actual practice as found in the real world. Schacht states specifically that there is inherently a conflict between curf on the

27 Chelhod $1986: 20$. 
one hand and Shar $\tilde{i}^{c}$ ah on the other ${ }^{\mathbf{2 8}}$. This gulf is quite apart from the fact that few human beings are capable of living up to the societal ideal. Although to an extent theory and practice may be divorced in any system of law, the gap is alleged to be particularly wide in the case of Islamic law, and the fact that Islamic law is a revealed law, impregnable to changing mores, is cited in support. As N.J. Coulson has put it,

Law, in classical Islamic theory, is the revealed will of God, a divinely ordained system preceding and not preceded by the Muslim state, controlling and not controlled by Mus 1 im society. 29

Many Muslims have criticised this attitude as being part of a condescending orientalist view of Islam. According to them, the question is not one of a gulf or a dichotomy between theory and practice. The real point is, as al-Azmeh has explained, the necessity of maintaining a distinction between shari ${ }^{c}$ ah (the divine law) and figh (the legislation) $\mathbf{3 0}$. For a Muslim, there is no difficulty reconciling the immutable divinely revealed law, the Shar $\bar{i}^{c} a h$, with the changes which occur inevitably with time in any society and which are the province of figh and concern the application of the usūt al-figh including where appropriate changes necessitated by changes in curf.

In any case, although ${ }^{c}$ urf on the one hand and fiqh and the Shar $\vec{i}^{c}$ ah on the other have been frequently set up as opposites, as heresy versus orthodoxy, the opposition is rarely more than rhetorical. Whatever parts of curf do not directly conflict with figh and the Shar $\vec{i}^{c}$ ah can be automatically included in them, and even if an aspect of curf is ostensibly at variance with figh and the Sharicah, a way can often be found, through the application of the principles of maslabah, istibsān and so on, of making it

\footnotetext{
28 Schacht $1964: 76$.

29 Coulson $1964: 1-2$.

30 al-Azmeh 1988.
} 
concordant. Even in the Yemen, where the Shar $\overline{\mathbf{l}}^{\mathrm{c}}$ ah has traditionally been identified with the learned Sadah, the Sayyid descendents of the Prophet, as opposed to the non-learned tribesmen with their curf as identified with the täghüt, and the constant attempts by the former to expand their understanding of the Shar $\bar{i}^{c}$ ah over the latter ${ }^{\mathbf{3 1}}$, the supposed Shar $\bar{i}^{c}$ ah-c urf conflict may be more rhetorical than real. As Paul Dresch concludes on the subject, "The implication of many Zaydi sources that there is a distinct customary code at odds with Islam is scarcely borne out"32.

If a valid distinction is to be made in terms of theory and practice it is not then in terms of Shar $\bar{i}^{c}$ ah versus fiqh, nor Shar $\bar{i}^{c}$ ah versus ${ }^{c} u r f$, but rather between Islamic law with all its attributes and in all its manifestations on the one hand and modern statute law (qānün) on the other. This distinction has been well recognised by Muslim authorities, and many attempts have been made over the centuries to reconcile the two, the 10 th/16th century Ottoman $\overline{q a} \bar{q}_{\bar{\gamma}} \mathrm{Ebu}$ ' $\mathrm{s}-\mathrm{Su}^{\mathrm{c}} \mathrm{ud}$ ( $\mathrm{Abu} \overline{\mathrm{u}} \mathrm{al}-\mathrm{Su}^{\mathrm{c}} \overline{\mathrm{u}} \mathrm{d}$ ) being perhaps the best known and most successful case in point ${ }^{33}$. At the same time, in many legal areas Islamic law as such is however either defunct or irrelevant in modern Muslim states. How slaves are to be treated or war booty shared are in this category. Both subjects are of great historical interest but neither is of any utility in current practice. Further, even in fields where the revealed law is still applicable, there are very few Muslim countries in which it has not been extensively modified and reformed since the mid-nineteenth century on principles the origin of which lies not in the Islamic tradition but in Western statute $1 \mathrm{aw}^{\mathbf{3 4}}$. As will be seen in the case of sharecropping in the Yemen (Section 3.5 below), however, even in

\footnotetext{
31 Cf. Serjeant 1977 :242; Dresch $1993: 183-186$.

32 Dresch $1993: 186$.

33 Ebu 's-Sucud and the integration he constructed between the Shar $\bar{i}^{c}$ ah and Ottoman qänün are the subject of a recent work by Colin Imber (Imber 1997).
} 
modern statute law any discordance between it and Islamic law may also be more apparent than real.

\subsection{The Sharecropping Hadiths}

\subsection{The Hadiths in Question}

Although in practice all four Schools of Islamic Sunn $\bar{i}$ law (the Hanafīs, Mālikīs, Hanbalīs and Shäficīs) and also the Shīcah Zaydī School accept the validity of sharecropping to a greater or lesser extent, they circumscribe the sharecropping contracts of muzāracah, musāqāh, mughārasah and the others with a large number of restrictions and conditions. Between and even within the Schools there is disagreement on what conditions make sharecropping contracts valid. Since there is no mention of sharecropping as such in the Qur'ān, the first of the two Primary Sources, jurists base their views ultimately on a number of badiths (Traditions) which specifically refer to renting out land and.sharecropping. The reasons for the lack of unanimity among the jurists on the validity or otherwise of the practice are largely to be found in the way the Sunnah of the Prophet has been narrated in these badiths.

It is the purpose of this Section (3.3) to examine in some detail these so-called sharecropping bad7ths, as recorded in the Sah̄ībs of al-Bukhärī and Muslim. Although there are four other collections of badiths which are regarded as canonical (eight others for the Mālikīs) those of al-Bukhāri and Muslim are the most prestigious and are considered to be the most authoritative, and discussion here will be limited to the texts of the bad7ths as recorded by them. The details of the editions consulted are given in full in the Bibliographyss.

34 There are many modern studies of the place of statute law in Muslim countries. For example, Anderson (1976) gives an excellent overview of modern Islamic law reform. Ballantyne (1990) studies the present position in the Gulf States. Rayner (1991) provides a comprehensive view of the Islamic law of contracts in theory and practice, again with particular reference to the Gulf States.

35 Under al-Bukhārī Sab̄ị; Khān (transl. and ed.) 1976; and Muslim Sab̄ib. 
Unfortunately, the relevant badiths give reason both to permit and to forbid the practice of renting out land for a share of the harvest. Because of this contradiction the section of the Traditions which deal with leasing land is indeed in the words of cAbdul Hamid Siddiqi "one of the most difficult chapters of Hadith"36. An examination of the relevant bad7ths shows that they fall into two categories: those in which the Prophet is said to have permitted sharecropping contracts and those in which he seemingly prohibited them.

\subsection{The Hadiths permitting sharecropping}

The first group - those which seem to permit sharecropping - tend to be narrated in the context of two historical events (though in fact in only one badith of this group is any of the terms for sharecropping (mukhäbarah) specifically used ${ }^{37}$ ). The first event is the arrival of the Muhājirūn at Medina when they were instructed by the Prophet to work the land of the Ansär for a share of the produce, the share being usually interpreted to mean a share proportional to the work they had exerted $\mathbf{3 8}$. The second event is the agreement the Prophet made with the Jews of the oasis of Khaybar some 90 miles $(145 \mathrm{~km})$ north of Medina, after they had submitted to him in the summer of $7 / 628^{39}$. By the terms of the agreement the Prophet allowed them to remain on their former land on condition that half the produce from it be given to him and the Muslims. Additionally, there are a number of badiths in which it is definitively stated that the Prophet did not forbid sharecropping though the specific historical context is not stated 40 .

36 Siddiqi 1976 :III, 815 fn.1998.

37 The bad7h in question here is al-Bukhārī Hadīth 523 .

38 The main bad7hth here is al-Bukhärī Hadjith 518, though other badiths refer to the same event.

39 For the historical event, see Veccia Vaglieri $E I^{2}$, article "Khaybar"; and Watt $1956: 217-19$. The main bad7ths here are al-Bukhāri Hadīths 521, 522, 524 and 531. 
Concerning first the situation on the arrival of the Muhājirūn at Medina, the relevant bad7th, which is transmitted ultimately from the Companion Abū Hurayrah, narrates that when the Ans̄ār asked the Prophet to divide up the date-palms between them and the Muhājirūn the Prophet refused, and the Anşār instead invited the Muhājirūn to tend the trees and share the fruit with them. Since in this bad7th the Prophet did not prohibit the arrangement this has been interpreted as supporting the validity of sharecropping generally, though others have held that the situation was specific to date-palm plantations and that validation can therefore be applied only to musāqāh (sharecropping involving irrigated perennials) and not to muzāracah (sharecropping on annually sown land)41. Others have gone further and hold that this badith does not validate sharecropping at all but rather refers to the specific historical situation from which no generally applicable giyās (legal analogy) can be drawn, since it was, in the words of S.M. Yusuf, "merely ... a generous attempt to assimilate the newcomers into the pattern of the economy"42.

Concerning the bad7ths which narrate how the Prophet dealt with the Jews of Khaybar, they all are transmitted ultimately from ${ }^{c}$ Abdallāh bn cumar, the son of the second caliph and therefore ostensibly an unimpeachable source. They recount how the Prophet allowed the Jews to continue to work the land on condition that they handed over to him and the Muslims half the produce from it. It is significant that two of these badîths as transmitted by al-Bukhār $\bar{i}$ state specifically that the produce might include either thamr (fruit) or zarc (grain), or presumably both43. Many jurists hold that this event can be extended by qiyass to sharecropping generally, including muzäracah (since zarc is mentioned), and this is their basis for regarding sharecropping legally valid. Others however

\section{0 al-Bukhārī Had̄̄ths 523 and 533.}

41 The terminology has already been explained in greater detail in Chapter 2 (Section 2.32 above).

42 Yusuf $1957: 33$. 
deny any possible qiyas and consider that the share of the crop handed over by the Jews was not a rent or payment for the usufruct but rather was in the nature of kharāj al-muqāsamah - that is to say, a tax on the land expressed as a proportion of the harvest 44.

As for the badiths which specifically deny that the Prophet forbade sharecropping, the first two concern Tāwūs, who reported that Ibn ${ }^{c} A b b a \bar{s}$, the cousin of the Prophet, had affirmed that the Prophet did not forbid sharecropping but rather had said that if a landowner could not cultivate his land himself it would be better for him to give it to a neighbour without charging rent. The critical wording is as follows:

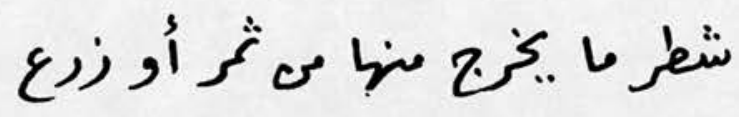

shatr mā yakhruj min-hā min thamr aw zarc ("half of any fruit or grain that is produced from [the land]").

In Hadjth 524 the wording is simply shatr mā yakhruj min-hä ("half of what is produced from [the land]"); and in Had7 th 531 nisf al-thamr ("half the fruit").

44 Cf. Yusuf 1957 :33. Concerning kharāj al-muqāsamah cAbd al-Khāliq al-Nawāwi has recently defined it as

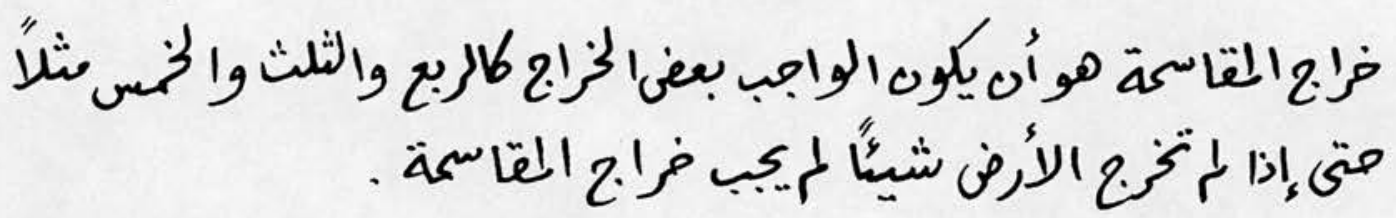

Kharāj a 1-muqāsamah huwa an yakūn a1-wäjib bac d a 1-kharāj ka-al-rubc wa-a 7-thulth wa-a7-khums mathalan battà idhä lam tukhrij a 1-ard shay'an lam yajib kharāj al-muqāsamah (The kharäj al-muqāsamah is [the term used when] the due is to be paid as a proportion of the produce, such as a quarter, a third or a fifth, for example, so that if the land produces nothing then the kharāj a 7-muqāsamah will not have to be paid) (al-Nawāwi $1973: 131$ ). The Ottoman Land Code (Article 2, Section iv) says that it is "proportional tribute" which is "levied to the amount of from one-tenth to one-half of the crop, according to the yield of the soil" (Fisher $1919: 1$ ). Incidently, the similarity of this kind of tax with sharecropping becomes very clear when the landowner is the state, in which case it can be difficult to distinguish between the tax due to the state by virtue of its being the state and the share due to the state by virtue of its being the landlord. 
in al-Bukhārī Had̄ith 523 :

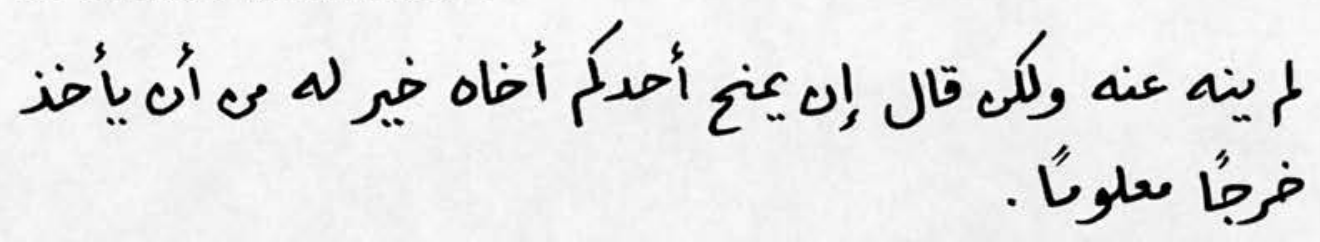

lam yanha [a 1-nabj] can-hu wa-Takin qā7 : in yamnab abadu-kum akhä-hu khayrun 1a-hu min an ya'khudha kharjan $m a^{c}$ Tuman;

and in $\mathrm{Had}_{7}$ th 534 :

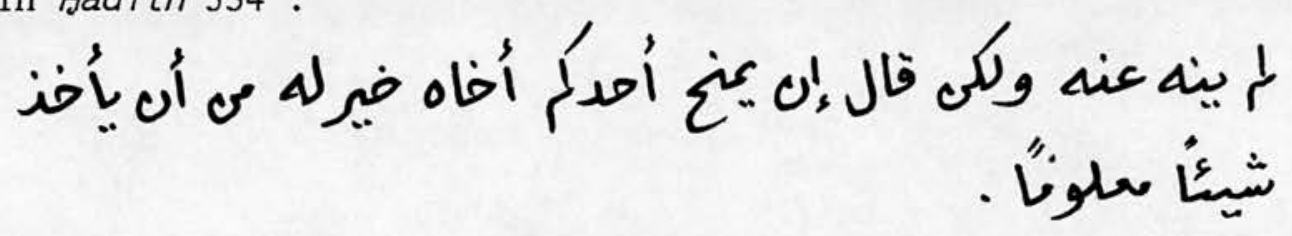

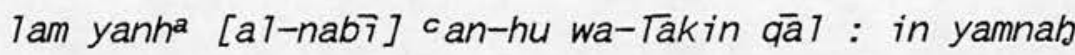
abadu-kum akhä-hu khayrun la-hu min an ya'khudha shay'an $m a^{c} T u m^{2 n}$.

Out of all the badiths which give support to the validity of sharecropping it is only in fact in Had7th 523 that the term mukhäbarah is specifically mentioned. If the term had not been stated, it might well be argued that neither of these had 7 ths refer to sharecropping at all but rather to leasing land for a fixed rent, since the kharjan mac Tuman and the shay'an mac Tuman could be construed to mean "fixed amount"

The third of this set of badiths, which is narrated ultimately from both Jābir and Abū Hurayrah, has no mention of Tāwūs or of the

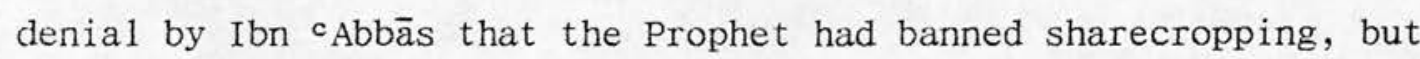
the rest of this badith is essentially the same as the. other two ${ }^{45}$.

All these badiths have been interpreted by many as meaning that it is only a recommendation of the Prophet that land which cannot be cultivated by its owner should be given to someone else free of charge, and not a definitive prohibition of sharecropping46. Others however have interpreted them more severely. S.M. Yusuf, for example, has glossed the Abū Hurayrah version of the badith as meaning that if someone had neither the capacity to till his land 
himself nor the generosity to give it to his brother to till, "then there was no alternative for him but to cling in a tenacious and foolhardy manner to his possession without any benefit to himself or to others"47. It is clear however that if the words of Ibn "Abbās as reported by Tâwūs are to be believed, in which the Prophet is recorded as explicitly not forbidding the practice, then such a strict interpretation as Yusuf's can hardly be adopted.

\subsection{The Had7ths prohibiting sharecropping}

The prohibitory badiths fall into two sets. The first concerns sharecropping as practised by certain of the Companions (Aşbāb) of the Prophet and their Successors (Tabicunn), including Zubayr bn Rāfic and 'Abdallāh bn 'Umar. All but one of these concern, and ultimately derive from, Zubayr's father Rāfic bn Khadīj48, and so for convenience they might be called "The Räfic Hadjths". It is expressly mentioned in these bad7ths that the landowner's share of the produce was the crop from a specified part of the land and that

45 al-Bukhāri Had̄ith 533. From Jäbir the wording is:

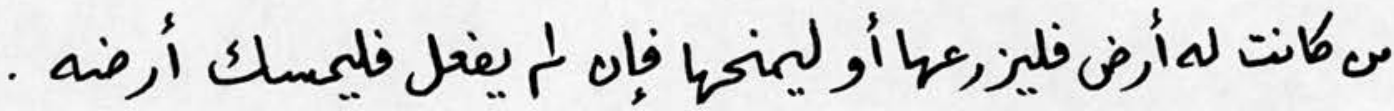

man kānat la-hu aroun fa-1-yazraca-hä aw la-yamnaba-hā fa-in lam yafcal fa-1-yumsik arga-hu;

and from Abū Hurayrah:

\section{منطانت له أرض فليزرعا أو ليمنحها فإن أبى فليحسك أرضه}

man kānat la-hu aroun fa-7-yazraca-hā aw la-yamnab-hä fa-in abā fa-1-yumsik arga-hu. Khan translates both of these versions as "Whoever has land should cultivate it himself or give.it to his (Muslim) brother gratis; otherwise he should keep it uncultivated".

46 For example, Khan 1976 :302 fn.1.

47 Yusuf $1957: 32$.

48 al-Bukhāri Hadiths 520, 525, 532, 535 and 537. Hadj th 535 (corresponding to Had7th 3736 in the Sabjh of Muslim) is narrated by Naffic, the mawTa of ${ }^{c}$ Abdallāh bn ${ }^{c}$ Umar and well-known narrator of bad7 ths. 
this practice was specifically prohibited by the Prophet. The second set are outright prohibitions of sharecropping and other types of pre-Islamic contract but they are narrated without historical context49.

(a) The Räfic Hadiths:

As regards first the Rāfic Hadjiths, all are concerned with a system of sharecropping in which the landowner's share is defined by the part of the crop from a specific part of the land. Three of them mention that the part of the land from which the landowner's share comes was cata $a 7-r a b \overline{7}^{c}$ or caTa $a 7-a r b i c \bar{a}$. M.M. Khan translates this phrase as "on the banks of the water streams", an interpretation which is supported by some of Lane's sourcesso. If

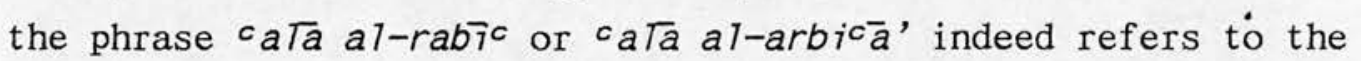
parts of the land alongside the water courses, then the prohibition of sharecropping in these circumstances is perfectly understandable: such land will normally have a higher productivity than land further away since it will be better watered, and the share the landowner takes would therefore be unfair to the sharecropper ${ }^{51}$. Moreover, according to two of these badiths, the landowner also received an absolute quantity of other produce, a situation which can again be interpreted as unfair to the sharecropper. These quantities over and above the landowner's proportional share are measures of dates

49 al-Bukhār $\overline{1}$ Hadīth 567; and Muslim :X, 194-196 in the Cairo (1929) edition (= Had7ths 3707 and $3709-3712$ in the Siddiqi (1976) translation).

so Khan 1976 :III 309, 310, 311; Lane :1019b, under $\mathrm{rab}_{\overline{7}} \mathrm{c}$ (pl. arbic'a').

51 At the present time in the Yemen land nearest a water channel has first call on the water, and the fields furthest away from the channel must wait for their share, a system summarised in the phrase a] $-a^{c} T a ~ f a-a 7-a^{c} T a$ (lit. "the highest [plot], then the [next] highest"; cf. Varisco 1982 :248-255 in al-Ahjur (northern Yemen); Serjeant $1964: 37-41$ in Haḑramawt; Maktari 1971a :56ff. in Labj (southern Yemen); Maktari 1971b:24-26 in Wādī Jīzān (Saudi Tihämah). Cf. also Bruno $1913: 36$, for the more general context.) In circumstances where there is a shortage of water the further fields may sometimes not be watered at all. 
and barley (awsuq min al-tamr wa-al-shacir ) in one case and of figs (shay' min al-tīn) in the other52. In addition, another of this set of badīths from Rāfic, though not mentioning specifically the banks of water channels, does state that if the crop is divided up by area then the part of the crop from one area of the land may not yield as highly as the other. This situation can also be construed as carrying more risk for one party to the contract than for the other. In short, then, the Prophet's prohibition of sharecropping under these conditions can be understood as concern that neither of the two parties to the contract, and in particular the sharecropper, is unfairly recompensed for his contribution to the enterprise.

There is a further point concerning one of these "prohibitory" Rāfic Hadjths ${ }^{53}$. It records that ${ }^{c}$ Abdallāh bn cumar, the son of the second caliph, used to rent farms during the time of the Prophet and throughout the caliphates of $\mathrm{Abu} \mathrm{Bakr}$, cUmar, and ${ }^{\mathrm{c} U t h m a \bar{n}}$ and into that of Mucāwiyah 54 and then heard the narration of $\operatorname{Ra}^{4} i^{c}$ bn Khadijj that the Prophet had forbidden the practice. That is to say,

52 A wasq ( $\mathrm{pl}$. awsuq) is a measure of capacity made up of $60 \overline{s a}^{c}$. According to Hinz (1955:53), it was equivalent to just over 252 litres as it was used in early Islam.

s 3 al-Bukhäri Hadīth 535 (corresponding to Hadith 3736 in the Sabīh of Muslim), narrated by Nāfic.

s4 The al-Bukhār $\bar{i}$ bad̄ith says "the beginning of Mucāwiyah's reign", but the version found in Muslim says "until the end of Mucawiyah's caliphate". The al-Bukhāri text of this section reads:

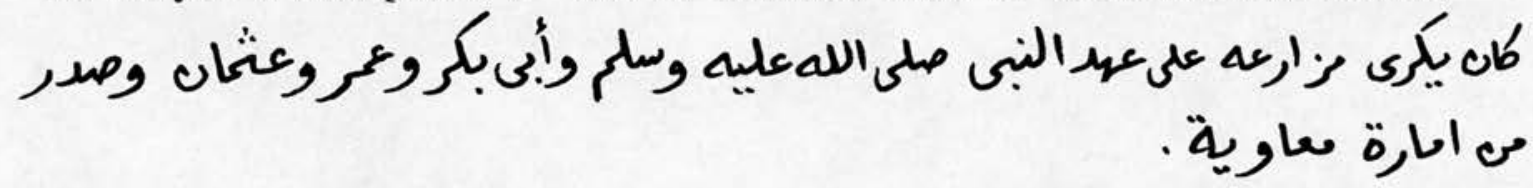

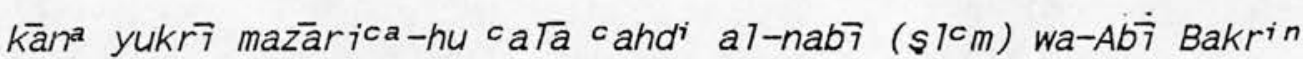
wa-eUmara wa-eUthmāna wa-sadran min imärat ${ }^{i}$ Mucāwiyata .

The Muslim version reads:

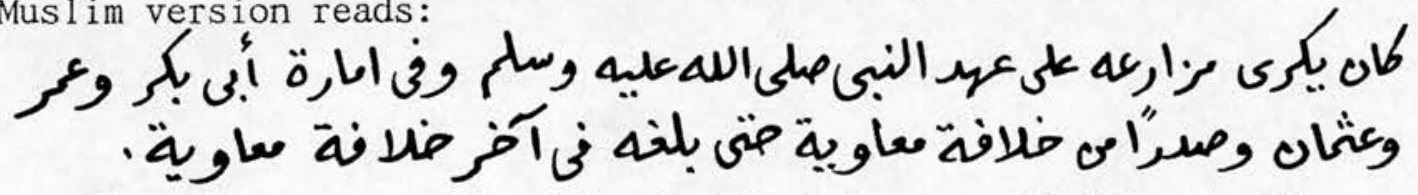

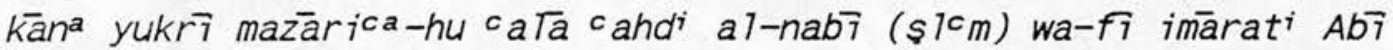
Bakrin wa-cUmara wa-cUthmāna wa-sadran min khi Tafat Mucäwiyata battā balagha-hu fī àkhiri khiTáfati Mucāwiyata. 
'Abdallāh bn cumar continued to lease land after the Prophet's death in $11 / 632$ until at least the $40 \mathrm{~s} / 660 \mathrm{~s}$ (that is, a minimum of thirty years), and possibly even until 60/680 (the end of the caliphate of Mucāwiyah), before he discovered that the practice was prohibited. If leasing land had indeed been formally forbidden outright by the Prophet it is strange (to say the least!) that between thirty and fifty years should have elapsed after the death of the Prophet

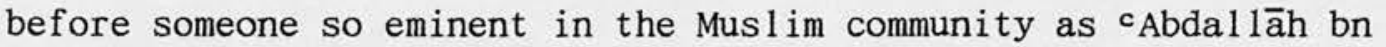
cUmar heard of the prohibition.

(b) The Prohibitory Hadiths without Context:

The second set of prohibitory badiths is more difficult to evaluate since the prohibition of mukhäbarah is stated bluntly and without historical contextss. What can be noticed however is that in each of them the prohibition of mukhäbarah is linked to prohibitions of other kinds of agricultural contract known as mubāqalah and muzäbanah, both of which are to be understood here as exchanges of ripe produce for produce not yet harvested56. Further, the prohibition here should be studied in relation to the two badiths which al-Bukhārī records immediately afterwards and which concern a permitted transaction called caraya $\bar{a}^{57}$. The texts of the relevant badiths in the Saḩ̄h of al-Bukhär $\bar{i}$ can be translated as follows:

\section{5 al-Bukhāri Hadjith 567; and Muslim :X, 193-196 of the Cairo (1929) edition (= Had7ths $3707-3713$ in the Siddiqi translation).}

56 For mubāqalah and muzäbanah, see the discussion on the terminology of sharecropping above (Chapter 2 section 2.3). These terms are explained also in the text of one of Muslim's bad7ths which will be examined below.

57 cArāya (sing. ${ }^{c} a r \bar{y} y a h$ ) is an exceptionally permitted exchange of dates which are still growing on the palm for dried dates up to the amount of 5 wasqs (see footnote 52 above for wasq). The quantity of dried dates can, of course, be measured, but the dates on the palm have to be estimated. This type of exchange was permitted, it is interpreted, to benefit someone who owns fruit growing on date-palms but needs fruit immediately and cannot wait for his fruit to ripen. 
Hadīth 567 (narrated by Jābir bn ${ }^{c}$ Abdallāh):

The Prophet forbade the mukhäbarah and the mubāqalah and also the muzabanah and the sale of fruit until it becomes visibly fit [for eating], and that [the fruit] is not sold other than by dīnār and dirham, except in the case of carāya.

Hadj th 568 (narrated by Abū Hurayrah):

The Prophet allowed carayā sale for which the [quantity of] dates is estimated, up to [a quantity] either less than or equal to 5 wasqs - Dāwüd [one of the isnad (chain of narrators)] is not sure which is correct.

Hadīth 569 (narrated by Rāfic bn Khadīj and Sahl bn Abī Hathmah):

The Prophet forbade the muzäbanah, [that is,] the sale of fruit for fruit, except for people who practise caraya which he allowed them.

The texts of the corresponding badiths in the Sabih of Muslim are essentially the same: prohibition of the contracts called mukhābarah, muhāqalah and muzäbanah, except for the case of carāyass. In addition, one of the bad7ths in Muslim's Sabīb includes also the prohibition of mucawamah ${ }^{59}$. All these types of prohibited contract are explained in Muslim's text according to Jābir bn 'Abdallah's narration. Mukhäbarah is when one man hands over ard bayda', (land without standing crops) to another who invests in it and gets a share of the produce in return. Muzäbanah is the sale of dates which are still on the palm for dried dates by an absolute measure (kaylan), while muhäqalah is the same as muzäbanah except it refers to grain - that is, the sale of grain which is still growing for grain already harvested. As for múāwamah, al-Shawkānī explains it as bayc al-sin̄̄n which may be interpreted as the sale now of a harvest expected years ahead 60 .

58 Muslim :X, 193-196 of the Cairo (1929) edition (= Had7ths 37073713 in the Siddiqi (1976) translation).

59 Muslim :X, 196 of the Cairo (1929) edition (= Hadith 3712 in the Siddiqi (1976) translation). 
Although admittedly there can be no clear-cut interpretation of these bad7ths which could entirely eliminate their prohibitory nature, nevertheless, if they are taken in their own context, and also in the light of the other badiths which would seem to allow sharecropping, it might be seen that what is being prohibited here is not sharecropping per se, but rather transactions which may result in unfairness or lead to speculation, and specifically speculation in agricultural produce.

\subsection{The Position taken by the Islanic Legal Schools}

The Sunnah, one of the two cardinal usüu (origins, principles) of Islamic law, then, provides no unambiguous ruling on whether sharecropping is permissible for Muslims to practise or not: Each of the relevant badiths, whether prohibitory or permitting, is open to a range of different interpretations. This explains why, in the words of S.M. Yusuf, "the issue remained undecided and men of piety always felt uneasy about it"61, and why therefore the early Islamic jurists, if they allowed the practice at all, circumscribed it with restrictions and conditions. It also explains why Louis Milliot, who was probably the first western legal specialist to make a detailed study of Islamic sharecropping in practice, said of it, "On peut dire qu'il y a presque autant de doctrines professées que d'auteurs ayant écrit sur la question"62. Milliot was here referring to the muzäracah but in fact his comment could well be applied to Islamic sharecropping much more generally.

It is in fact practically impossible to summarise succinctly the conditions with which jurists have circumscribed sharecropping for it to be a valid contract63. One reason for this is that the different Schools impose different sets of conditions and there is, moreover, no unanimity even within each School. For example,

\footnotetext{
60 al-Shawkānī Nayl al-Awtār :V, 280; Siddiqi 1976 :III, 810
}

( Hadith 3712).

61 Yusuf 1957 :32.

62 Milliot $1911: 17$. 
although the eponym of the Hanafi Madhhab, Abū Haniffa (d. 150/767), ruled against the validity of muzāracah, his two eminent disciples, Abū Yūsuf (d. between 172/798 and 179/807) and Mubammad al-Shaybāñ̄ (d. 189/804), permitted the practice as long as certain conditions were met64. Another reason for the difficulty in attempting to summarise the various conditions is that different types of sharecropping contract are considered differently, and in particular a basic distinction is made between muzäracah and mukhäbarah on the one hand and mughārasah and musāqāh on the other - that is to say, sharecropping in annual crops (typically grains) and sharecropping in perennial crops (tree crops and vines). The nineteenth century Ottoman Land Code (essentially a Hanaf $\bar{i}$ document) does not distinguish between mughärasah and musāqāh, as was noted in Chapter 2 (Section 2.32 above), though most jurists define them separately, in the manner to be discussed below. Moreover, Shāf $i^{c} \bar{i}$ jurists, following al-Shāficī's lead, have tended to forbid muzāracah as an independent free-standing contract but have allowed it if it is part of a musāqāh contract, a point which will also be taken up below (in Chapter 4).

Comparing the mughärasah and the musāqāh, the essential distinction between them which most jurists tend to make is that in the mugharasah contract, the sharecropper is leasing the landowner's land as a tenant, whereas in the musāqāh, the landowner is hiring the services of a sharecropper as a labourer, as was mentioned in Chapter 2 (Section 2.32). In the musāqāh, the owner of the land will also own the trees which will usually be already mature when the contract is made. In the mughärasah, however, the responsibility of both supplying and planting the trees will frequently lie with the sharecropping tenant. In return, not only will he receive a share of the eventual produce of the trees, but

63 M.J.L. Young (EI², article "Muzāraca") gives eight conditions required for a muzâracah contract to be valid. However, he makes no allowance for the different views of different jurists and the real position is much more complex than he suggests.

64 See, for example, Abū Yūsuf Kitāb a 7-Kharāj :176-177. 
also, often, he will acquire ownership of part of the land. This is justified by the fact that such contracts will inevitably last many years without any return for the tenant-planter since he must wait for the trees to mature. Mughärasah contracts of this type (where the tenant-planter supplies the young trees and acquires part of the land) would seem to have been particularly favoured by the Māliki School, since it is well documented that in Mālikī North Africa large areas of previously uncultivated land were planted with olive trees and other fruit trees between the end of the nineteenth century and the Second World War by means of mughärasah partnerships between the colonial landowners and the Arab farmers, and it was the latter who supplied the young trees and received ownership rights in the land in return $\mathbf{6 5}$. As will be seen in the next section (Section 3.5 below) the Yemeni Civil Code (a 7-Ganūn a7-Madan̄i) too allows for this type of mughärasah.

It will be the task of Chapters 4 and .5 to discuss the views of specifically the Shäfic $\bar{i}$ and Zaydi Schools on sharecropping. Here only a brief appraisal of some basic differences will be given in the approaches of the different Schools to the practice 66 .

Generally speaking, all the four Sunni Schools and the Zaydi and other $\operatorname{ShI}^{\mathrm{c}}$ ah Schools have less difficulty accepting the validity of sharecropping contracts on land planted with perennial crops and requiring irrigation (that is to say, musāqāh contracts) than contracts on annually sown land (that is, muzāracah contracts) 67 . On the theoretical level the justification which the Schools cite is the Khaybar bad7 ths already discussed above. On a more pragmatic level it is tempting to see at least part of the reason in the fact

65 See especially Rectenwald 1930 :75-79; and also Milliot 1911 :34-61 and 100-129; Abribat 1934:121-125; and Roussier-Théaux 1935 $: 129-135$. The French term for such mugharasah contracts is bail à complant.

66 The following summary owes much to the detailed account provided by al-Jazir $\vec{i}(1969$ :III, 1-33) of the position on the muzāracah and musāqāh taken by the four Sunnī Schools.

67 Cf. Løkkegaard $1950: 174$. 
that to estimate a future harvest on irrigated land, especially that planted with perennial tree crops (such as date-palms, vines or cotton), is more certain and therefore has less risk inherent in it than to estimate the harvest on land which has not yet been sown. As will be seen in Chapter 4 (Section 4.2 ), none other than the great al-Shāficī himself cited this pragmatic reason for the acceptability of musāqāh but not of muzāracah.

Concerning muzäracah contracts, there is in fact a notable divergence in approach between the schools on the theoretical level. The majority of both the Hanbalis and the Hanafis allow muzāracah as an ijärah (renting or hiring) contract whether it is renting land for part of the produce or hiring a labourer whose wage will be part of the produce. In both cases such contracts are heavily circumscribed with conditions, including the stipulations that the shares of each party to the contract must come from the whole of the land and not a certain specified part of it and must be stated in terms of a proportion of the total crop and not as an absolute measure. Both of these stipulations are clearly based on the restrictions found in the sharecropping bad7 ths already discussed (Section 3.3 above).

The majority Shäfic $\bar{i}$ view is different in that both renting land for a part of the produce and hiring a labourer for part of the produce are in principle considered forbidden because of the existence of gharar (risk), and in particular any detriment such gharar could cause to the labourer. If, for example, no crop at all is produced, then the labourer will have been placed in the iniquitous position of having worked for no wage. Most Shäficis therefore regard muzärácah contracts invalid - though even here there are exceptions. The main method by which a muzāracah contract can be considered valid, according to most shäficiss, is when it is an integral part of a musāqāh contract. That is to say, if a musāqāh contract is concluded for a piece of land under date-palms or other irrigated perennial crops it can contain within in it a muzāracah contract which will allow the labourer to sow land under, between and beside the trees ${ }^{68}$. 
Most Mālikis on the other hand validate sharecropping not as an ijärah contract but as a form of sharikah (partnership) contract and therefore very similar in its conditions to mudarabah (commercial partnership). Each partner then receives his share as ribh (profit) in proportion to his investment, and the problem of renting the land for an unknown ujrah (rent) or hiring a labourer for an unknown ajr (wage) does not arise. The Māliki conceptualisation of sharecropping as a partnership is fully borne out by the practical example given above concerning the use of mughäasah contracts in establishing olive plantations in North Africa: in these contracts the planter-tenant is far from being a hired labourer. He is in fact a fully operating and fully contributing partner with the landowner and is rewarded commensurately.

As for the Zaydīs, the Shīcah School of most importance in modern Yemen, their view would seem to be the most pragmatic of all. The relevant sections of the Zaydi fiqh works a7-Bahr al-Zakhkhär of Ibn al-Murtad̄a and the Nayl al-Awtār of al-Shawkānī will be examined in detail in Chapter 5. Here it need be said only that the Zaydis permit all three major types of sharecropping contract (that is, muzāracah as well as mughärasah and musāqāh) and the conditions with which they circumscribe the contracts are notably much less onerous than those stipulated by, for example, the Shäficīs.

All the Schools therefore allow sharecropping to some extent. Equally however all stipulate detailed conditions surrounding matters such as whether the contract should be for a fixed period of time; which party to the contract is to supply the seed and the àtat a)-zare (the agricultural implements and any animals necessary for ploughing, harvesting, and so on); whether the tenant or labourer should be required to perform duties additional to the ploughing of the land and the sowing, tending and harvesting of the crop; and how he should be recompensed for any permanent structures (new water channels or cisterns, or terracing, for example) - but inasfar as

68 The Shāfic $\bar{i}$ view, as exemplified by al-Shāfic $\bar{i}$ himself and by al-Nawaw $\overline{1}$, will be examined in detail in Chapter 4. 
they concern the Shäfici and Zaydi Schools these detailed matters will be given further consideration in Chapters 4 and 5 below.

\subsection{Sharecropping in the Yemeni Civil Code al-Qanün al-Madan $\overline{7}$}

It will be shown in Chapter 6 (in particular in Section 6.4) of this thesis that sharecropping is by far the most widespread form of agricultural tenancy in the Yemen. It is not surprising therefore that the Yemeni Civil Code (a 1-Qanūn a 1-Madan $\overline{7})$ should address the practice. The Code was promulgated by the government of the (then) YAR as Laws 10 and 11 of 1399/1979 (comprising Books 1 and 2 of the Code) and Laws 16 and 17 of 1403/1983 (comprising Books 3 and 4), and as such can be considered an example of modern statute law. However, the opening of Book 1 which sets forth the principles on which the Code is based clearly states that its basis is the Islamic Sharicah and the Us̄ut a7-Fiqh69.

The Articles in the Civil Code relevant to sharecropping contracts, eleven in number, are Articles 733 to 744 inclusive and are found in Book 3 (which deals with Contracts), Part II, Chapter 1 (on Leasing), in which they constitute Section 4 entitled a7-Mughärasah wa-a7-Muzäracah wa-a7-Musāqāh (pp.79-81). The Mughärasah forms Subsection 1 (Articles 722-736, :79-80) while the Muzārácah and the Musāqāh are grouped together in Subsection 2 (Articles 737-741 for the Muzäracah and Articles 742-743 for the Musāqāh, with Article 744 applying to both the Muzāracah and the Musāqāh).

Each Article is provided with an "Explanatory Note" (mudhakkirah $\overline{7}$ dabjyah) after the end of Book 4 (pp.317-320), though in many cases these notes do not advance the depth of one's understanding of the Articles, since they often merely restate in identical words what the original Article states.

The text of the Articles together with their Explanatory Notes is given in full for reference in Appendix $2^{70}$. What follows here is a summary of the contents of the Articles and a discussion of them.

69 a 7-Qänün al-Madan̄ī, :I, Articles 1 to $21(: 17-20)$. 


\subsection{The Articles on the Mughärasah (733 to 736)}

The purpose of Article 733 is to outline the situation in which a mughärasah contract would be valid and the main points may be summarised as follows:

- Mughārasah contracts involve a perennial crop ${ }^{71}$. The Explanatory Note gives as examples date-palms and grapevines (a clear recalling of the Khaybar bad7ths).

- The area of land to be covered in the contract is to be specified.

- The type of plants is to be specified.

- The tenant $(a \hat{\jmath} \vec{r} r)$ is to provide the plants and tend them until the fruit is produced. The Explanatory Note refers to the tenant also as ghäris (1iterally planter, especially of trees).

- The rent may be either part of the land or part of the harvested fruit (or, presumably, both, though this is not stated) $\mathbf{7 2}$.

- Neither party may annul the contract without the consent of the other.

The Explanatory Note justifies mughärasah contracts by invoking maslabah (public welfare or benefit) and states that the ijmāc unanimously declares them valid because of the bad 7 th from Ibn cumar concerning Khaybar.

70 A full translation into English has been considered unnecessary here. The language of the Code is modern Arabic and poses no real problem of comprehension when the terminology of sharecropping is known. The two or three misprints in the original printed text have been noted and corrected in Appendix 2 of this thesis.

71 shajar la-hu aş thäbit: literally, trees which have firm or established trunks/roots.

72 The possibility that a share of the land can be made over to the tenant in a mughärasah contract (instead of, or as well as, a share of the produce) is significant and recalls the remarks made in the previous Section (3.4) concerning contracts of this type in North Africa. 
Article 734 states what the position would be if a mughärasah contract is found to be invalid because one of its conditions is defective. In such a case, any trees which have already been planted would belong to the tenant (ghäris) (who supplied them in the first place) and he would pay the landowner a rent commensurate with the period of time his trees had occupied the land. The tenant would then have two choices: he could either uproot the trees, or he could leave them standing and claim their value from the landowner.

The following Article, 735, would seem to be curiously placed here since it concerns the law of trespass or usurpation rather than the regulation of the mughärasah. The Article states that if anyone plants or builds on a plot of someone else's land without the owner's permission, then the plants or buildings must be removed by the person who put them there, and that person must also pay the landowner a commensurate rent and an indemnity.

Article 736, the final Article in the section on the mughärasah, states simply that any aspect of the contract not covered by the previous Articles is to be referred to local custom, the curf al-jihah. The statement is significant in highlighting the relationship between Yemeni statute law, as exemplified by al-Qānun a)-Madan $\overline{7}$, and the curf: where statute law has nothing to say, it is customary law which is applied.

\subsection{The Articles on the Muzäracah (737 to 741$)$}

Article 737 out lines the conditions under which a muzāracah contract is valid, and these can be summarised as follows.

- Muzäracah contracts involve leasing land to a tenant (aj $\overline{7} r$ ) who will cultivate it by sowing (zarc).

- The plot of land, the type of seed and the length of the period of the contract must all be specified.

- The contract may be annulled only in one of the following three situations:

- both parties agree to the annulment;

- the tenant fails to meet the conditions of the contract;

- the tenant refuses to hand over the rent. 
The Explanatory Note adds that muzäracah contracts have been deemed valid by the "council" ( Tajnah, presumably the committee of Yemeni legal experts which drew up a $7-\bar{Q} a n \bar{u} n$ al-Madan $\overline{7})$ even though the rent is expressed as a proportion of the harvest. The justification given by the Explanatory Note is, once again, the bad7 th recounted from Ibn cUmar concerning the Prophet's deal with the Jews of Khaybar, and that contracts of the muzāracah type were practised by Muslims throughout the Prophet's lifetime and the reigns of the Rāshidūn caliphs ${ }^{73}$.

Article 738 is concerned principally with the conditions under which the muzāracah contract may be terminated. Briefly, these are stated as follows, and in each case the landowner would have the right to remove the tenant $(a \bar{\jmath} r$ ) from the land.

- The tenant breaks the rules as set by custom (idhā khälafa a 1-curf).

- The tenant neglects or abandons his duties or infringes the conditions of the contract.

- The tenant is unable to work (presumably, though this is not stated, because of old age or ill health and so on).

In return, the tenant has the right to be recompensed for the labour he has expended.

The Article then states that after the harvest either party has the right to terminate the contract provided the other party is notified in good time. The Explanatory Note adds that if the length of the muzäracah contract has not been specifically declared it would run for a single crop (zarcah), that is to say, normally one year, and would end after the crop had been harvested, unless renewed by both parties. In cases where there are more than one harvest per year, as with vegetables and the like, the. Article indicates that procedures should be governed by custom ( ${ }^{c} u r f$ ).

Article 739 is a straightforward prohibition of leasing land to a tenant $(a \bar{j} r)$ to cultivate for the landowner when the tenant's

73 The relevant bad7ths have been discussed already in Section 3.3 above. 
remuneration is the crop from another piece of land also worked by the tenant. The Explanatory Note calls this type of arrangement the mukhäbarah and quotes as the justification for its prohibition the bad7 th recounted from Ibn ${ }^{c}$ Umar $^{74}$.

Article 740 simply states that the tenant (muzäric) may not desert the land nor sub-let it to someone else without the permission of the landowner.

The final Article dealing specifically with the muzāracah, Article 741 , concerns the situation where the tenant (aj $r$ ) decamps after he has ploughed and tilled the land but before he has sown it. Normally he will have no right to be compensated for the labour he has expended, since, as the Explanatory Note clarifies, he will have failed to have met the conditions which the contract has imposed on him. He will have the right to compensation for his labour however in two situations: in a case where the contract turns out to be invalid through the deficiency of one of its conditions; or in a case where he has good reason to quit early (though what constitutes a good reason is not defined).

\subsection{The Articles on the Musāqāh (742 to 743 )}

Article 742 outlines what constitutes a valid musāqāh contract. In it the owner of trees (gharas) or other crops (zarc) hires a labourer (cámil) to irrigate them and carry out such other duties as are necessary to look after them. The Explanatory Note refers to the labourer as musāq $\overline{7}$ as well as $c \bar{a} m i \overline{7}$, and it adds that the amount of the hire (ujrah) is a proportion of the produce from the land. The contract may be annulled only in the following circumstances:

- with the consent of both parties;

- negligence or infraction on the part of the labourer;

- failure on the part of the owner to fulfil his responsibility to pay the labourer his hire.

74 The various versions of this bad7th have been discussed in Section 3.3 above under the subsection "The Rāfic Hadjths". 
If the contract itself is found to be deficient before the labourer had started work because one of its conditions is invalid, then it is simply annulled. If the labourer has already started work, then he has the right to be recompensed in a measure equivalent to the labour he has expended.

Article 743 states that the labourer (cámi 7 ) is forbidden to abandon his duties to someone else except with the permission of the owner, and it is therefore essentially the same as the prohibition in Article 740 concerning the muzāracah.

\subsection{The Article relevant to both the Muzāracah and the Musāqāh} (744)

Article 744, which applies to both the muzāracah and the muisāqāh, concerns disagreements which may arise between the two parties. The first involves the ujrah, the rent in the case of the muzaracah or the hire or wages in the case of the musāqạh. Where no evidence exists to support either party, then such disagreement is to be resolved in favour of the party who claims the lower amount. The second concerns a dispute over what the tenant or labourer may or may not do. In such a case the landowner will have the decisive say.

\subsection{Observations on the Sharecropping Articles in a 1-Qanūn a $1-\operatorname{Madan} \overline{7}$}

The vocabulary employed in the above Articles for the two parties and their relationship with each other indicates the attitude of a 1-Qänūn a 7-Madan̄ to the nature of each of the types of contract and in particular to the distinction the code makes between the mughärasah, the muzäracah and the musāqāh. In the mughärasah the landowner (mālik al-ard) hires or engages (yasta'jir) a tenant (referred to as aj̄ir or sometimes ghäris). In the muzāracah the landlord (referred to as rabb al-ard, though there is likely to be no significant difference between this term and mālik al-ard) leases or rents out a piece of land (yu'ajjir ardan) to a tenant (here also referred to as $a j \overline{7} r$ or sometimes muzāric). At one point (Article 740) the landlord is referred to as the lessor, mu'ajjir. In the 
musāaāh, the owner is not referred to specifically as the landowner (though he is likely to be that as well) but rather as the owner of the trees or crops (mālik gharas aw zarc), and he hires (yasta'jir) an agent who is effectively a labourer (camil, which the Explanatory Note to Article 742 refers to also as musāq $\overline{7}$, literally irrigator).

In short, then, the Yemeni Civil Code regards all three sharecropping contracts as ijärah (leasing, renting or hiring) contracts (indeed, Chapter 1 of Part II of Book 3 in which the Articles on sharecropping are found deals with ijärah), rather than as sharikah (partnership) contracts on the analogy with mudarabah as discussed in Section 3.4 above. However, there are differences in approach to the three types of contract according to which party is leasing or hiring and what or who is being leased or hired.' The three situations are summarised in Table 3.1 .

\section{TABLE 3.1 : RELATIONSHIPS BETWEEN LESSORS AND LESSEES IN SHARECROPPING CONTRACTS AS VIEWED BY THE YEMENI CIVIL CODE}

Contract

Party

leasing/hiring
Thing/person being leased/hired

\begin{tabular}{|c|c|c|}
\hline mughärasah & $\begin{array}{l}\text { Landowner } \\
\qquad(\text { mâlik a l-ard) }\end{array}$ & $\begin{array}{l}\text { Tenant } \\
\text { (aj)ir or ghäris) }\end{array}$ \\
\hline muzāracah & $\begin{array}{l}\text { Tenant } \\
\qquad(a j \bar{i} r \text { or muzāric) }\end{array}$ & $\begin{array}{l}\text { Land } \\
\qquad(a r d)\end{array}$ \\
\hline musāqāh & $\begin{array}{c}\text { Owner of plants [and land] } \\
\text { (mâlik gharas aw zarc) }\end{array}$ & $\begin{array}{l}\text { Labourer } \\
\qquad\left(c^{c} \bar{a} m i \bar{l} \text { or musāqa }\right)\end{array}$ \\
\hline
\end{tabular}

As the table shows, in the case of the mughärasah, the landowner is hiring or engaging a tenant (to plant the land with trees, and, moreover, to supply the trees, and possibly benefit from ownership of a share of the land at the end of the contract). In the muzāracah, the tenant is renting land from the landowner. In the musāqāh, on the other hand, the owner is hiring a labourer, and the situation is similar therefore to the mughärasah except that the 
musāqāh labourer is contracted to provide nothing but his labour. In the case of both the mughärasah and the muzāracah the engaged person is distinguished by the term aj $\bar{r} r$ (tenant). These distinctions will be met again when Yemeni sharecropping contracts are examined in more detail in Chapter 8 (Section 8.3). Notwithstanding the distinctions, however, the recompense (expressed as a proportion of the harvest, of course) is referred to in all the Articles as ujrah, whether meaning rent or wage.

The way the three kinds of contract are grouped is also undoubtedly significant. Instead of the more usual grouping of muzäracah on the one hand against mughärasah and musāqāh on the other (which, in the case of at least the Ottoman Land Code, is so marked that the latter two have completely coalesced, as has been mentioned above in Section 3.4), the Yemeni Civil Code makes mughärasah stand separately in its own subsection, and groups muzāracah with musāqāh in a separate subsection. This is likely to be because of the special position the tenant in a mughärasah has, as outlined above, when compared with the tenant or labourer in the other contracts. The grouping may also reflect Shāficī influence, in that the only valid form for a muzäracah contract is when it is an integral part of a musāqāh contract, as will be discussed in more detail in Chapter 4 . Since however the Civil code allows muzāracah as a free-standing contract without any stipulation that it must be tied into a musāqāh, as the Shāf $i^{c}{ }^{c}$ is would have it, it can by no means be regarded as a Shäf $i^{c} \bar{i}$ document. Instead, pragmatic Zaydi influence would seem to show quite visibly in these sharecropping Articles.

A subsidiary point of interest can perhaps be made which concerns problems and disputes that may arise during the term of the contract. It would seem clear that the Yemeni Civil code gives more prominence to possible shortcomings on the part of the sharecropper than any on the part of the landowner. Although it is stressed in all three contracts that if the contracts are validly concluded then the contractual conditions are binding on both parties (Articles 733, 737 and 742), nevertheless the Articles dealing with both the mughärasah and the muzāracah place emphasis on infractions which the 
tenant may commit, no mention at all being made of any possible grievances the tenant may have because of the actions of his landlord. Only in the musāqāh (in Article 742) is a possible infringement on the part of the landowner referred to (failure to pay the labourer). This matter will be referred to again in Chapter 8 below when contentions and their solution are discussed in the context of the Yemen.

What is perhaps as interesting as the points which the Articles include is matters which they omit. There is no mention for example of any permitted range of sharing proportions or on what basis they should be calculated. Similarly, with the exception of the stipulation that in the mughärasah the tenant should supply the trees, no mention is made concerning which party should provide the inputs such as the seed and the àtat al-zarc (the necessary equipment and tools), and equally no mention of whether the tenant is responsible for transporting his landlord's share to him or whether the landlord is expected to make his own arrangements to collect his share. Another omission is any specification of whether a contract should be a written document or whether a verbal agreement is sufficient, nor on any procedure for witnessing the contract. Since these and other crucial matters are completely ignored by the Articles in the Code, it must be assumed that they should be decided by local curf, and indeed in the mughärasah and the muzäracah (in Articles 736 and 738) the reader is referred explicitly to the curf where there is no specific ruling in the Code. This also is an important point which will reappear in Chapter 8 (Section 8.3) when Yemeni contracts are discussed.

\subsection{Concluding Remarks on Sharecropping in Islamic Law}

After giving an explanation of some of the basic terminology and concepts of Islamic law, this chapter has sought to show the relationship of curf to the Shar $\bar{i}^{c}$ ah including the means by which and the extent to which the former has contributed to the latter, and it has also analysed in some detail the so-called Sharecropping Hadiths which, in the absence in the Qur'ān of any direct reference, form the starting point for all Islamic legal discussion on the 
practice. As has been indicated, no unambiguous judgment can be framed from the badiths, which are contradictory, on the legal status of sharecropping, though the present writer has tentatively drawn his own conclusion - namely, that the intention of the badiths is not that sharecropping per se is prohibited but rather only those forms of the practice which incorporate gharar and can lead to speculation or which may be considered intrinsically unfair to either of the two parties and especially the sharecropper. This conclusion will be referred to again in Chapter 5 (Section 5.4) when it will be shown that it is also the conclusion arrived at by the (nominally) Zaydī Yemeni jurist al-Shawkānī.

The chapter has concluded with a discussion of the relevant Articles in the modern Yemeni Civil Code which deal with sharecropping, and it was pointed out that it is not surprising that the Civil Code should concern itself with sharecropping since the practice is so widespread in the Yemen, a point which will be amply illustrated in Part II of this thesis. It was shown that the three types of sharecropping contract mughārasah, muzāracah and musāqāh, are all regarded by the Civil Code as leasing or hiring contracts, though each is distinct concerning which party is doing the leasing or hiring and what or whom is being leased or hired. In this it may be contrasted not only with the strict Shäfic interpretation in which only musāqāh and a limited form of muzāracah are allowed (though this point will be elaborated in the next chapter, Chapter 4 ), but also with the ottoman Land Code which admits only two categories, muzāracah and a combined musāqāh/mughärasah. A further point which was made and one which will be commented on again in Part II is the emphasis the Civil code gives to infractions on the part of the tenant or labourer while any offences the landowner may commit are hardly mentioned. A final point was that the sharecropping Articles in the Civil Code would seem to be as equally interesting for what they omit as for what they include.

A very general overview of the positions taken by the main Islamic legal Schools has also been introduced in this chapter. It is now time to focus more specifically on the attitudes to sharecropping of the two Schools which are of principle concern in 
the Yemen: the Shäficis (the subject of Chapter 4) and the Zaydis (Chapter 5). 
CHAPTER 4 : THE SHĀFICI POSITION ON SHARECROPPING

4.1 Introductory Remarks

4.2 Al-Shāfici on Sharecropping in the Kitāb al-Umm

4.21 Al-Shāf $i^{c} \bar{i}$ and his Kitāb al-Umm

4.22 A Synopsis of the Bäb al-Muzāracah with Comments

4.23 Discussion

4.3 Al-Nawawi on Sharecropping in the Minhäj al-โălibīn

4.31 Al-Nawawī and his Minhāj al-Tălibīn

4.32 A Synopsis of the Kitāb al-Musāqāh with Comments

4.33 Discussion

4.4 Concluding Remarks on the Shāf $i^{c} \bar{i}$ Position 


\subsection{Introductory Renarks}

As has been mentioned in Chapter 1 (Section 1.3) and elsewhere in this thesis, the majority of the population in the west and south of the Yemen adhere, in theory at least, to the Shäfic $\bar{i}$ School of Islamic law. The intention of this chapter is to study in some detail the Shāfici position on sharecropping. The sections on sharecropping in two works, both basic to the thinking of the School, have been selected for this: the Kitāb al-Umm of al-Shāfici himself (d. 204/820), from which the Bäb a7-Muzāracah is examined in Section 4.2; and the authoritative Minhäj al-Tăibīn of Muby $\bar{i}$ al-Dīn Yahyā bn Sharaf al-Nawawi (d. 676/1277), which work has come to be one of the most respected textbooks of the mature form of Shāficism and from which the Kitāb al-Musāaāh is studied in Section 4.3.

\subsection{Al-Shäfici on Sharecropping in the Kitäb al-Umm}

\subsection{Al-Shāficī and his Kitāb al-Umm}

The Imām Abū cAbdallāh Muhammad bn Idrîs al-Shāficī, the eponymous founder of the third, chronologically, of the four Sunni legal Schools, is one of the greatest and most influential thinkers and scholars of the period of initial development of Islamic law ${ }^{2}$. He was born in 150/767 into the Hāshimi branch of the Quraysh tribe, and so he was a relative, albeit a distant one, of the Prophet. After his early legal training at Mecca al-Shäfic $\bar{i}$ spent a period in Medina as a disciple of Mālik bn Anas until the latter's death in

1 The main secondary sources on which the following background information on the life, works and thinking of al-Shäfici has been based are: Khadduri 1961; Baker and Edge 1990; Schacht 1950; Schacht 1964; Brockelmann 1937-49 :Geschichte I, 190; Chaumont EI a (article "Al-Shāficī"); and Chaumont EI b (article "Al-Shāficiyya"). Reference has also been made to Yāqūt's Muc jam al-Udabä' (:VI, 394-95). 
179/796. Within a few years an allegation that he was involved in cAlid conspiracies in the Yemen and was a secret supporter of the Zaydī Imām Yabyā bn cAbdallāh who was claiming the caliphate, caused al-Shāfici to be deported to Iraq, and he was put on trial in 187/803 before the cAbbāsid Caliph Hārūn al-Rashīd ( reg.

170/786-193/809). As a result of his impressive self-defence he was befriended by the great Hanaf $\bar{i}$ jurist Muhammad bn al-Hasan al-Shaybānī (d. 189/804), the disciple of both Abū Hanīfah and Abū Yūsuf, who according to some authorities helped secure al-Shāficī's pardon, and by $194 / 810$ he had established himself as a teacher in Baghdad.

Armed now with first hand experience of the thinking of both the Hijāzī-based Mālikī School and the Iraqi jurists represented by the Hanafi School, he decided to leave Baghdad in $198 / 814$. It would seem at least likely that, given his earlier imprisonment, al-Shāfici had resolved to avoid any further involvement in politics and devote himself wholly to the law. After a brief spell of teaching at Mecca where he is reputed to have impressed Abmad bn Hanbal (d. 241/855) who was studying there at this period, al-Shäfici settled in the then political backwater of Egypt.

Al-Shäficī died in Egypt in 204/820, after being physically attacked, according to a story recorded by Yāqūt $\mathbf{2}$, by a band of Mālikis who had been enraged by his skilful rebuttal of Māliki reasoning. His body lies in the Southern Cemetery of Cairo, overlooked by the Muqattam Hills and only a few hundred yards from the tomb of his near contemporary Dhū al-Nūn al-Misri $(A b \bar{u}$ al-Fayd Thawbān, đ. 245/859) who is revered by S̄ūfis. Al-Shāficī's burial place has ever since been a locus of pilgrimage for his disciples and admirers, and over it Saladin (al-Mālik al-Nāşir Salāh al-Dīn Yūsuf al-Ayyūbī, d. 589/1193) and his immediate successor Ayyūbids later built in his honour the great mosque-madrasah which still stands today.

2 Yāqūt Mú jam al-Udabā' :VI, 394-95. 
Al-Shäfici is rightly regarded as the founder of the first comprehensive system of Islamic jurisprudence based on the four principles of the Qur'ān, the Sunnah, the Consensus of Jurists ( $i j \overline{a^{c}}$ ) and Legal Analogy (qiyās), which are collectively called the usūu al-fiah ${ }^{3}$. It was under al-Shäfici that, in the words of Joseph Schacht, "legal reasoning reached its zenith"4. Although after him jurists would argue the particulars of the system he had constructed, few would take issue with the overall formulation.

His position relative to the Mālikis on the one hand and the Hanafis on the other has been summed up by Brockelmann who says of him, "His madhhab attempted to reconcile Mālik's dependency on the Traditions with the principle of ra'y (personal opinion) held by Abu Hanīfah"s. Al-Shāficī certainly saw no place in Islamic law for custom ( ${ }^{c}$ urf $)$, in marked denial of the position adopted by the Mālikis, while in contrast to the Hanafis, al-Shāficī's approach was to deny on principle any place in law to discretionary or arbitrary decisions and opinions (istibsān, ra'y) and to limit analogy (qiyās) to only that which is strict and systematic. For these reasons his rulings and those of the followers of his school tend of ten to be more stringently dependent on a narrow interpretation of the Qur'ān and the Traditions than those of other Schools. As will be shown, this stringency is to be seen in al-Shäfic ${ }^{c}$ 's attitude to sharecropping contracts.

Al-Shäficī's thinking and that of the School he founded is of particular importance in the Yemen since the largest part of the country by area, which is probably the largest part in terms of population also, has traditionally owed loyalty to that School. The

3 The legal terms ijmāc, aiyās, ușül al-fiqh, together with others to follow (curf, istibsān, ra'y, etc., which are again mentioned in the text below), have already been discussed above in Chapter 3 (Section 3.2).

4 Schacht 1964 :45; cf. Brockelmann 1937-49 :Geschichte I, 190.

s Brockelmann 1937-49 : Geschichte I, 190. Brockelmann's original words are: "Sein Madhab suchte zwischen der überlieferungstreue Māliks und dem Ra'yprinzip a. Hanīfas zu vermitteln". 
areas of the Yemen which have been historically Shäfici are largely coincident with what has been called in Chapter 1 (Section 1.3) "Lower Yemen", which forms the larger part of the country (roughly, the west, the centre and the south). Most of the Yemen therefore, in theory at least, is and has been Shäfic $\bar{i}$ in its religious out look for many centuries.

Al-Shāficī's literary output is said to have included over 100 works on 1 law $^{6}$, of which only a few remain extant. Of these, Kitäb al-Umm and al-Risālah are the two best known ${ }^{7}$. The Risālah was the first systematic study of the sources of jurisprudence (the usū 7 al-fiah) ${ }^{\mathbf{8}}$. As such the work was extremely influential among later generations of jurists, not only within what became the Shäfici্i School but also in the other legal Schools. Abmad bn Hanbal, for one, is known to have regarded al-Shāfic ${ }^{\top}$ 's Risālah very highly ${ }^{9}$.

The Kitäb a T-Umm, which is considered by many as al-Shāficī's magnum opus $\mathbf{1 0}^{\mathbf{0}}$, is in fact a collection of most of his later Egyptian writings. They were collected, probably by his disciples, into nine books, most of which are of a polemical nature and concern al-Shäfici' 's disagreements with other eminent jurists of his day. The least polemical of the nine books is Book 7 , entitled Ibtā 7 a)-Istibsān (the Invalidation of Discretionary Opinion), a title which refers to al-Shāficī's rejection of this form of reasoning as a basis of the law, an outlook which has already been mentioned above. It is in this seventh book of the Kitäb al-Umm that is to be found systematic discussion of particular legal questions and subjects. It is therefore the chapter on sharecropping (entitled

6 Baker and Edge $1990: 144$.

7 Khadduri $1961: 40 \mathrm{ff}$.

8 There is also his Tartīb al-Musnad in which he collects together under systematic headings the badiths together with their isnäds (chains of transmitters) that he refers to in the Kitäb al-Umm.

$9 \quad$ Khadduri $1961: 42$.

$10 \quad$ Baker and Edge $1990: 145$. 
Bäb a 7-Muzāracah) in the Kitāb a 7-Umm which has been chosen for study here as the most concise statement of al-Shāficī's own thinking on the subject. The edition used here is the 1321-26[/1901-06] Būlāq edition'11.

\subsection{A Synopsis of the Bäb al-Muzäracah with Comments}

Al-Shāfici begins his chapter on sharecropping with a short statement of two forms it might take: first, muzäracah in which the plot of land alone is handed over to the labourer with a sharing proportion of a half, a third or a quarter of the harvest, and second, what al-Shāficī calls here mưãmalah (deal, dealing) in which it is date-palms or other trees which are being handed over, for a half or more or less of the harvest. This mucamalah clearly refers to musāqāh sharecropping contracts, and although these terms are not used by al-Shäfici at this point it is clear that his use of the muzāracah in the title of the chapter is intended to encompass all forms of sharecropping and not just the muzäracah proper.

He then states that Abu Hanifah'12 declared all such sharecropping contracts invalid $(b \bar{a} t i 7)$ on the grounds that "[the landowner] has hired [the labourer] against something which is unknown (majhü7)" and so if there were no harvest at all the labourer would have laboured without any remuneration. Al-Shāficī then notes that Ibn Abi Laylä13 on the other hand ruled all such dealings permitted $\left(\overline{j a}^{\prime} i z\right)$ on the grounds of certain badiths and including the Khaybar bad7hth 14 and the analogy (qiyas) with the

11 In this Būlāq edition Báb al-Muzäracah is found in Vol. VII, 101-102. As far as can be established, no translation of the Kitäb al-Umm into a western European language has been publișhed.

12 Abu Haniffah: d. 150/767, which incidentally was the year of al-Shäfici্', s birth; eponym of the Islamic School.

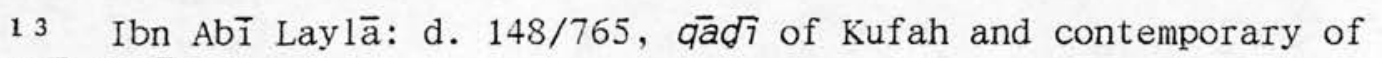
Abū Hanīfah.

14 The relevant badiths which relate that the Prophet reportedly allowed sharecropping have been examined in detail in Chapter 3 (Section 3.32 above). 
commercial profit-sharing partnership called mudarabah (in which one partner provides the capital and the other the time and expertise required to invest the capital in a business deal, the proceeds of which are then shared on an agreed basis between the two parties). Since, Ibn Abì Laylā's argument goes, three of the Companions (cumar bn al-Khațtāb, cAbdallāh bn Mascūd and cuthmān bn ${ }^{c}$ Affān) involved themselves in such contracts, there can be no objection to mudarabah. Since, further, two Companions ( $\mathrm{Sa}^{\mathrm{c}} \mathrm{d}$ bn $\mathrm{Ab} \overline{\mathrm{i}}$ Waqqās and again $\operatorname{Ibn}_{\text {Mas }}{ }^{\mathrm{u}} \mathrm{d}$ ) used to grant their land for a third or a quarter of its produce, the implication is that sharecropping may be lawfully practised, under some circumstances at least, on analogy with mudarabah.

Al-Shāf $i^{c} \bar{i}$ now states his own view in which he distinguishes sharply between land with and land without perennial crops:

If one man hands over to another man date-palms or grape-vines in which he is to work on the understanding that the labourer gets a half or a third of the fruit or some other proportion of [the fruit] which the two [parties] have fixed mutually as a condition, then this musāqāh is the legitimate [contract] by which the Messenger of God (may peace be upon him) dealt with the people of Khaybar.

If [however] a man hands over [a plot of] ard bayda', (land on which there are no perennial crops) to another man on the basis that the latter cultivates it - [that is, ] the plot of land - and one part of anything which God causes to be produced from [the land] belongs to him, then this is the mubāaalah, the mukhäbarah and the muzäracah which the Messenger of God (may peace be upon him and his family) prohibited. 15

That is to say, sharecropping in date-palms and grape-vines on the one hand (the contract called musāaāh) is valid on the grounds of the Prophet's action at Khaybar. Sharecropping on arable land with no perennial crops (ard bayda', literally "white land") on the other hand is what the Prophet prohibited (according to several

is Al-Shāficī Kitāb al-Umm :VII, 10131-32. The sentence which constitutes this last paragraph here is quoted verbatim by al-Shawkānī in his Nayl al-Awtār, :V, 9. 
Traditions) as the mubāqalah, the mukhäbarah and the muzāracah'16. As further justification of his view al-Shäfici points out that we must be clear about whether actions have been permitted or prohibited. He says:

The prohibition of what [the Prophet] has prohibited us is no more obligatory for us than the permissibility of what he has allowed us, and it is not for us to cast away one of his two Traditions for the other, nor should we declare prohibited on the grounds of that which he has declared prohibited anything he has declared permissible, in the same way as we do not declare permissible on the grounds of that which he has declared permissible something he has declared forbidden. 17

That is to say, to paraphrase, permissibility and prohibition are equally binding and neither takes precedence. So if one action is permitted and a related action prohibited, we must accept this as being so, and we have no justification to permit both actions on the grounds that one of them is permitted, nor to prohibit both actions on the grounds that one is prohibited. In other words, a prohibition cannot be used as a qiyās to make an otherwise permitted action prohibited, nor vice versa.

It follows then that, in al-Shäfic $\bar{i}$ 's view, Abū Hanīfah was wrong in judging all sharecropping prohibited simply because one form of it has been prohibited, and Ibn Abi Laylā was equally wrong to judge all forms permissible just because one form is permissible.

For al-Shäfici's argument there remains now only the problem of the badîth about the Companions $\mathrm{Sa}^{\mathrm{c}} \mathrm{d}$ bn $\mathrm{Ab} \bar{i}$ Waqqās and ${ }^{\mathrm{C} A b d a l l a ̄ h}$ bn Mas $^{c} \bar{u} d$ leasing their arable land under a muzäracah contract. Al-Shāficī's solution is to declare the Tradition unreliable despite

16 These terms mubāqalah, mukhäbarah and muzāracah have been explained in Chapter 2 (Section 2.32) of this thesis. Presumably al-Shäficī did not hold that the term mukhäbarah is derived from Khaybar, since the Prophet's action at Khaybar is al-Shäfici's's justification for the validity of musāqāh, and yet he states now that the Prophet forbade the contract of mukhäbarah.

17 Al-Shāficī Kitāb al-Umm :VII, 1022-3. 
the fact that, as he acknowledges, it concerns people so close to the Prophet. His argument here is that it is foolish to try to confirm the Sunnah of the Prophet by referring to a Tradition of some of the Companions. If certain forms of sharecropping are permitted on the grounds that they are similar to mudarabah, it must be remembered that this basis for their permissibility is only an analogy and not a basic principle in its own right.

Further, any analogy with muđarabah must be strictly applied. Al-Shäfici goes on to argue the strict basis for the analogy by introducing it with the rhetorical question, "How does the mudarabah resemble the musāqāh?" He answers it by saying, in effect, that the essential characteristic of the musāqāh is that the thing that is being handed over to the labourer is the date-palms themselves which are visible and extant ( $q \bar{a}$ ' $i m a h)$ and which therefore can be used to derive an estimate of the size and quality of the future harvest. This argument of al-Shäficī's therefore avoids the problem of an unknown quantity in the contract: the date-palms are themselves the measure of the future harvest to be shared out between the two parties to a musāqāh contract in the same way as the proceeds of a mudarabah deal would be shared out.

If then a questioner goes on to ask, "why cannot this also be so on [arable] land?", al-Shäfic $\overline{1}$ 's reply is essentially that arable land which is without perennial crops and is by definition re-sown each year cannot be treated in the same way as land with perennial crops since the land cannot form a basis on which to estimate a future harvest. The only thing visible and extant at the time the contract is made is the land, and it is not the land but an as yet still unsown future crop which is to be shared.

Al-Shäfici concludes the chapter by stating that even if it were to be attempted to make sharecropping on arable land permissible on the basis of analogy (with either the mudarabah or the musāqāh - it is not entirely clear which is intended, though this point would not appear to be crucial for this part of al-Shäficī's argument), this itself would not be permissible, since analogy cannot overturn a prohibition the Prophet himself has made. 


\subsection{Discussion}

In sum, then, al-Shāficī's position on sharecropping can be stated quite simply: he upholds the validity of sharecropping contracts when they involve perennial crops (following the bad7ths he allows dates and grapes in this category), and thus disagrees with $\mathrm{Abu}$ Hanifah; but he denies the validity of sharecropping contracts when they involve annually sown arable land, and so disagrees with Ibn $\mathrm{Ab} \overline{\mathrm{i}}$ Laylā.

The reasoning by which al-Shāf $i^{c} \bar{i}$ arrives at this position can perhaps be viewed on two levels. Ostensibly, his reasons are founded primarily in the badiths, and in particular the Khaybar Traditions, to which he refers, and secondarily on a strictly applied qiyās with muđarabah contracts. It is perhaps not impossible also that his argument can be taken at a deeper level at which one can discern a more pragmatic and humane reasoning. This is suggested by the following interpretation.

It is clear that al-Shäfic $\bar{i}$ regards a sharecropping contract as a contract in which a landowner hires the services of a labourer rather than as a contract in which one man leases land as a tenant from a landowner. There are three points indicating this. The first concerns the terms al-Shäficī uses to indicate the sharecropper. Apart from calling him rajul, al-Shāficīi refers specifically to the sharecropper only twice in the Báb al-Muzäracah - once by the term cámil (worker, labourer, the one who does the work) and once by the term musāqā (irrigator under a musāqāh contract), and never by a term which means tenant or lessee ( $a \hat{j} \bar{r} r$, musta'jir, mustakrī, etc.) such as are found in discussions on sharecropping in other legal works. Second, the expressions used throughout to indicate the initial situation in such contracts (idha actā al-rajulu al-rajula ardan ... ; idhā dafaca al-rajulu i Ta al-rajuli al-nakhla wa-al-cinaba ... ; in which the verbs mean respectively to give $\left(a^{c} t \bar{a}\right)$ and to hand over (dafaca)) nowhere include verbs meaning to let or to lease (akrā, ajjara, etc.) which again are common in other works by other jurists. Third, although al-Shäficī rejects Abū Hanīfah's conclusion that all forms of sharecropping are invalid, he does not reject specifically the 
reason $A b \bar{u}$ Hanifah gives for this conclusion: that is, that a complete failure of the harvest would mean that the labourer would not receive any recompense for his labour.

It would indeed seem to be the case that only if al-Shāficī's words are viewed in this light can the basis for the distinction he makes between sharecropping in perennial crops and sharecropping in arable land be understood in practical terms, whatever the basis in the Traditions. In the former case of perennial crops it is possible, according to al-Shāfici $\bar{i}$, to make at least an estimate of the future harvest (from the number, size and general appearance of the trees or vines), and so it can be inferred that any labourer who took on the job of irrigating and tending the crop would have some degree of certainty about how much he would receive for his work at the end of the season. In the case of arable land however there is nothing initially but the land itself bare of any plants, and therefore nothing for the labourer to base any estimate of the reward he could expect for the labour he would expend. If al-Shäfic $\bar{i}$ 's argument is regarded in this light, then, his major concern would seem to be for the welfare of the sharecropper - or in his terms, the labourer.

On the other hand, al-Shäficī's reasoning would break down in the case of the mughärasah type of contract, which, however, he does not mention. As with the date-palms and grape-vines of al-Shäficī's musāqāh, which he permits, the mughärasah also involves perennial tree-crops, and by al-Shāfic $\bar{i}$ 's own argument the future crop might be estimated well before it is harvested - at least, after the trees have become established. It is not clear why al-Shäfici omitted all mention of the mughärasah - unless, of course, the term had not emerged as referring to a specific kind of sharecropping contract in al-Shäficī's time in the late second/eighth century, even though for later lawyers it was to become one of the three principal permitted types, alongside musāqāh and (with restrictions) muzāracah.

It must be said that other jurists since al-Shäfic $\vec{i}$ have viewed the relationship between the two parties in a sharecropping agreement in different terms and have come to different conclusions about the validity or otherwise of such types of contract in Islamic 
law. An examination of the attitudes of various subsequent jurists to sharecropping is one of the themes of this thesis. The two extreme positions have in fact been introduced by al-Shāfici himself in the Băb al-Muzāracah of the Kitāb al-Umm, as has been shown above: in the views of $A b \bar{u}$ Hanifah who denied the validity of any such contract, and of Ibn Abi Laylā who allowed all such contracts. The Yemeni Civil Code too takes a line divergent from that of al-Shāficī, by allowing the mughärasah and the muzäracah as well as the musāqāh, as was seen in Chapter 3 (Section 3.5 above). The next Section (4.3) studies the views on sharecropping of the seventh/thirteenth century Muby $\vec{i}$ al-Din al-Nawawi, probably the single most influential thinker of the Shäfici School in its mature form.

\subsection{Al-Nawawi on Sharecropping in the Minhäj al-Talibinn}

\subsection{Al-Nawawi and his Minhäi al-Tälibīn}

The Imām Mubyī al-Dīn Abū Zakarīyā' Yahyā bn Sharaf al-Hizāmī al-Dimashq $\bar{i}$ al-Nawaw $\overline{1}$ was born in $631 / 1233^{18}$. His birthplace was the town of Nawā, in eastern Jawlān, some 45 miles $(70 \mathrm{~km})$ south of Damascus, hence the nisbah by which he is generally known (and which is sometimes written al-Nawāwi). From $649 / 1251$ he studied in Damascus and his subsequent writings attracted the attention of the Damascus Där al-Had7th, the Ashrafiyah, in which he became a teacher in $665 / 1267$ at the age of 34 . He remained there until he dared to disobey the Mamlūk sultan al-Malik al-Zāhir Baybars (al-Bunduqdārī; reg. 658/1260-676/1277) by refusing to sign a fatwā declaring legal the war taxes and other exactions imposed by the Mamlūks on Syria. He eventually returned to his birthplace of Nawā and died there in $676 / 1277$.

While still at the Ashrafiyah in Damascus, his reputation as a religious scholar of the Shäfici School grew rapidly, especially

is The main secondary sources on which the following background information on the life, works and thinking of al-Nawaw $\bar{i}$ has been based are: Heffening EI (article "Al-Nawawi"); Brockelmann 1937-49 :Geschichte I, 496-501; and Chaumont EI ${ }^{1} \mathrm{~b}$ (article "Al-Shäficiyya"). 
after the completion in $669 / 1270$ of his greatest work in the field of figh, the Minhāj al-Tălibin (literally, the Path of the Searchers), which has ever since been regarded among the shäficis as one of the two or three most authoritative figh works of their School. The two later commentaries on it (the Tubfat al-Mubtāj of Ibn Hajar al-Haythamī (d. 975/1567), and the Nihāyat a 1-Muhtāj of Shams al-Din al-Ramlii (d. 1006/1596)) have since served as textbooks for the teaching of the Shäfici Madhhab ${ }^{\mathbf{1 9}}$. It is because of its standing in Shäfici thinking that it has been selected here to represent the developed Shäfici view of sharecropping.

A translation, commissioned by the Dutch colonial government in Batavia (now Jakarta, Indonesia), was published in 1883 in French by L.W.C. Van Den Berg together with his edition of the Arabic text for which he evidently used at least four separate Mss. The chapter in the Minhäj al-Tăibīn which deals with sharecropping is entitled Kitāb a 7-Musāqāh and is to be found in Volume II of the Van Den Berg edition $\mathbf{2 0}$. It is this edition of the Arabic text which has been used for study here. It would appear to be clear and sound, and there are apparently only three small corrections which have to be made. These are:

1) yufsal in place of bufsal (:1443);

2) $a 7-a b \bar{a} j \overline{7} n$ in place of $a 7-a j a ̄ j 7 n(: 1481)$;

3) jadhādhu-hu in place of jadâdu-hu (:1483);

As for Van Den Berg's translation, it is called "much criticised" by E. Chaumont $\mathbf{2 1}$, and indeed it is easy enough to find fault. The English translation of excerpts in Section 4.32 below are the present author's own and keep much closer to the original text than does Van Den Berg's original.

19 Brockelmann cites over thirty Arabic commentaries on the Minhäj a7-Täibinn (Geschichte: I, 496-98) and he identifies numerous Mss. of it (Geschichte :I, 496 and Supplement :I, 680).

20 Al-Nawawī Minhāj al-Tăibīn :II, 143-149.

21 Chaumont $E I^{1} \mathrm{~b}$, article "Al-Shaficiyya" :188b. 


\subsection{A Synops is of the Kitäb al-Musāaāh with Comments}

Al-Nawawi's first statement concerns defining the type of situation in which a musāqāh contract could legally apply. First, each party must be "jâ'iz al-tasarruf", that is to say, legally able to dispose of his property, and if he is either too young or else insane, then his guardian would have to act for him. Such restrictions concerning minors and the insane apply throughout Islamic contract law22. Second, the musāqāh applies to date-palms and grape-vines, though al-Nawawi notes that in his early writings al-Shāficī included also the possibility of other types of fruit trees $\mathbf{2}^{3}$. As has been seen in Section 4.22 however, al-Shāfic $\bar{i}$ made no such supplementary possibility in the Kitāb al-Umm, which was a late composition of his, and preferred to restrict the contract to date-palms and grape-vines, which indeed reflects the wording of the relevant Khaybar badiths, as studied in Chapter 3 (section 3.3 above).

Although al-Nawaw $\vec{i}$ is here concerned principally with the musäqāh, since, as has been shown above (Section 4.2), al-Shāfic $\bar{i}$ considered this type of contract the only type which could be valid when standing alone, he then goes on to define the difference between mukhäbarah and muzäracah, the former being where the labourer supplies the seedcorn and the latter where the landowner supplies it, and to state that both are invalid, with one exception.

22 See, for example, Rayner $1991: 122-125$. In her discussion Rayner is dealing specifically with the contract of bayc (sale), but the two primary restrictions to legal capacity (minority and insanity) apply equally in other contracts, since bayc is the Islamic contract par excellence on which the others have been formally modelled. See also, for example, Schacht 1964 :124-125 for the various levels of legal capacity and responsibility in Islamic law.

23 The Arabic text reads:

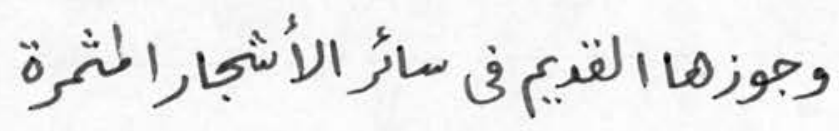

wa-jawwaza-hā a 7-qadīmu fị sä'ir a 7-ashjār al-muthammirah (:1432-3), in which the term a7-qadjm refers to al-Shäficī's early writings. 
That exception is, in short, a muzāracah contract which is subordinate to a musāqāh contract and effectively an integral part of it. That is to say, as al-Nawawi puts it,

If there is some bayad (unplanted land) in among the date-palms, then the muzäracah is valid as part of a musāqāh contract over the date-palms, on condition that the same camil (labourer) is involved [in both contracts] and that it would be difficult to irrigate the date-palms separately from cultivating [the ground round about them]. The valid position is that it should be a condition that the two contracts are not separated, and that the muzäracah does not form the largest [part of the combined contracts]. [Otherwise it is not important whether] there is a large amount of bare land or a small amount. ${ }^{24}$

The conditions then for a muzāracah to be valid according to al-Nawaw $\vec{i}$ may be summarised as follows:

1) the muzāracah must be an integral and inseparable part of a musāqāh contract;

2) the camil (labourer) for each must be the same man;

3) it would not be practicable to irrigate the part of the land under the muzäracah separately from the date-palms subject to the musāqāh;

4) the muzāracah does not dominate the combined contracts.

As al-Nawawi goes on to say, however, it is not a requirement that the fruit be shared in the same way as the grain. That is to say, the two parties may agree to divide the fruit from the musāqāh and the grain from the muzärac ah between them at harvest in different proportions (for example, a one-third to two-thirds sharing of the dates but a fifty-fifty sharing of the grain, though al-Nawawi does not give any specific example, or indeed any indication at all of how large or small shares may legitimately be).

In contrast to the muzäracah, which in this restricted situation is valid, al-Nawaw $\overline{1}$ then states that the mukhäbarah (where

24 Al-Nawawĩ Minhāj al-Tălibīn : II, 1436-1444. 
the tenant, not the landowner, supplies the seedcorn) can never be legally valid.

Al-Nawawi's next concern is to determine what should be done if a muzāracah contract happens to be concluded separately from a musāqäh contract, and therefore illegally. In such a case, he says, the harvest will belong to the landowner and he will be responsible for paying the cämil a wage for his labour and any animals and equipment he has supplied, though how the harvest is gathered will be up to the two parties to decide. In other words, the same agricultural work could continue as usual, but with the camit now as a fixed-wage labourer and not as a sharecropper.

Al-Nawawi then adds two further situations in which a musāqāh contract would be invalid. The significance of each case is somewhat difficult to see at first sight, even when nouns are interpolated for the pronouns. The Arabic translates as follows. The musäqäh will not be valid if either of the following is true:

(1) if [the tenant] hires out [his services to the landowner] for half the seedcorn so that he can sow the other half [of the seedcorn] for [the landowner] while [the latter] lends him half the land;

(2) if [the tenant] hires out [his services to the landowner] for both half the seedcorn and the use of half the land so that he can sow the other half [of the seedcorn] on the other half of the land.25

What al-Nawaw is referring to here is the kind of sharecropping arrangement which partitions the crop between the landowner and the sharecropper not by proportions measured from the total crop harvested from the whole land, but rather on the basis of the parts of the crop grown on different plots of the land by assigning the produce from one plot to one of the parties and that from another plot to the other party. As was seen when the so-called Rāfic badiths were discussed in Chapter 3 (Section 3.33 above), sharecropping on such a basis was forbidden specifically and unambiguously by the Prophet, and it was suggested there that the

25 Ibid. :II, 1448-1454. 
reason for the prohibition was that different parts of the land might not be equally productive. The matter is taken up by many authorities in addition to al-Nawawi: the subject is discussed at some length for example by al-Shawkānī, as will be shown in Chapter 5 (Section 5.3) when his comments on sharecropping in his Nayl a)-Awtär are examined.

There then follow statements of several further conditions which are necessary for a musāqāh contract to be valid. The first concerns the initial ownership of the crop: it should be owned in common by the two parties jointly. That is to say, it is not the landowner's for him then to hand over the tenant's share, nor is it the tenant's for him to hand over the landowner's share.

The second condition in this section is more complicated and has to do with the relationship between the length of contract, the period necessary for trees to produce fruit, and whether it is valid for the tenant to be asked to plant the trees himself (in which case, of course, the length of the contract would have to be several years). Although al-Nawawi does not use the term, this last possibility is clearly the kind of contract called by other authorities mughārasah, as discussed in Chapter 3 (Section 3.4 above). The Arabic of this passage translates as follows:

A musāqāh can be validly concluded after the fruit has begun to appear as long as it is before there are signs of maturity. [However,] if [the landowner] hires [the tenant] under a musāqāh contract, [giving the tenant] date-palm shoots ${ }^{26}$ for him to plant and the [mature] palms would become the property of both parties, then [such a contract] is not valid. Only if [the date-palms] are already planted [before the contract] [would it be valid] to make it a condition for [the tenant] to receive a share of the fruit as recompense for his labour, and then only if the period in which the fruit is normally produced has been specified. If this not so, then [the contract] is not valid. 27

26 Wad7y, as listed by Lane (1863-93:3051c).

27 Al-Nawawī Minhāj al-Tălibīn :II, 1456-1463. 
Here, then, al-Nawawi accepts the validity of a musāqāh contract shorter than one year, as long as the fruit has not already begun to mature. On the other hand, in his view a musāqāh contract can cover only trees which are already planted and may not involve the tenant in planting them - that is to say, the mughärasah for al-Nawaw $\overline{1}$ is invalid, even though he does not use the term. Nevertheless, he does add that some (unnamed) authorities do allow such contracts of the mughärasah type.

Al-Nawawi then states in a straightforward manner his three last conditions for a valid musāqāh contract:

[To be valid a contract] has the following [further] conditions:

(1) Obligations must not be placed on the $c^{-a} m i l$ to carry out anything that is not to do with his work [of cultivating];

(2) [The camil] should alone be the one who is in charge of the work in the plantation;

(3) The period of work [of the contract] must be known, in terms of, for example, "one year", or more. It would not be valid [to specify] the length of time [of the contract] by saying "[until the time] the fruit matures".28

His next concern is to quote the form of words to be used to make a valid musāqāh contract:

The correct form [of words to make a musāqāh contract] is [for the landowner to say]: "Saqqaytu-ka cata hädhä a 7-nakh] bi-ka-dhā" (I engage you in a musāqāh contract over these date-palms in such-and-such a way); or else: "Sallamtu-hu ilay-ka 7i-tatacahhada-hu" (I hand [the date-palms] over to you so that you might take care of them). Then [the camil] has to show his acceptance, without all the details of the work involved [having necessarily been named]. What is not specified in any respect is to be referred to a -c $^{-}$urf a 7 -ghälib (the dominant custom).29

It will be noted from this passage that in making a musāqāh contract the emphasis is on the words actually spoken. That is to

\footnotetext{
28 Ibid. : II, 146s-1472.

29 Ibid. : II, $1472-5$.
} 
say, it is essentially a verbal process. The significance of this will be made clearer in Chapter $S$ (Section 8.3 below) when Yemeni contracts are examined in some detail. The acceptance (qubū 7 ) by the tenant is also verbal and seals the contract.

A further significant point from this passage, and one which will also emerge again when Yemeni contracts are discussed, is that the precise duties of the tenant need not be spelt out as part of the contract-making process, and that "the dominant custom" of the district is to be the arbiter of what is required of him. Nevertheless, al-Nawawi then proceeds to 1 ist what a tenant's duties are.

It will be the responsibility of the ${ }^{-a m i} 7$ to do whatever he has to do to make the fruit ripen, and in addition to carry out those things which recur each year such as irrigating, cleaning out the water channels, keeping in good repair the abäjin [the depressions around the bases of the date-palm trunks] in which the irrigation water is kept from flowing away30, pollinating, clearing away grass and weeds, pruning damaged parts [of the trees], and setting up trellises [for grape-vines], according to custom (cādah). Similarly, [it will be the oâmil's responsibility] to protect the fruit, to harvest $\mathbf{3 1}$ it and to dry it. 32

Al-Nawawi then states what should be specifically excluded from a tenant's duties and should be carried out instead by the landowner:

30 In Van Den Berg's Arabic text of the Minhäj al-Talibinn the word ahājīn has been wrongly printed ajājin (:II, 1481), and it is translated into French somewhat misleadingly as "réservoirs" (: II, 147). The term will be met again in Chapter 8 (Sections $8.21,8.32$, 8.52 and 8.53 ).

31 In Van Den Berg's Arabic text of the Minhäj a7-Tälibinn the word jadhädh has been misprinted jadăd (:II, 1483).

32 Al-Nawawi Minhāj al-Tä7ibīn :II, 1476-1484. 
Anything which involves maintaining the $\operatorname{trees}^{\mathbf{3} 3}$ but does not recur each year, such as building walls and digging new water channels, is the responsiblity of the landowner. ${ }^{34}$

To conclude his chapter on sharecropping al-Nawaw $\vec{i}$ explains what the procedure should be in the event of any of four untoward situations occurring during the term of the contract. These situations are: a tenant who decamps; a tenant who dies; some breach of the contract on the part of the tenant; and the removal of the fruit before the tenant has received his proper share.

In the case of the decamping tenant, the landowner may voluntarily complete the work himself, but the tenant would still be held liable to pay him damages or indemnities. Otherwise, the băkim, literally (in the field of disputes) the arbitrator, which here may be interpreted as the local governor or his legal appointee, can hire someone else to finish the work, and charge the cost to the now absent tenant. If the landowner is not able (for some unspecified reason) to take the case before the bākim, then he should at least get witnesses to testify to the sums he is having to

33 The Arabic here is bifz a 7-as7, where as 7 would mean either roots or trunks or both and thus "trees".

34 Al-Nawawi Minhäj al-Täibīn :II, 1484-s. Van Den Berg's translation of the first part of this passage is unsatisfactory. The Arabic reads:

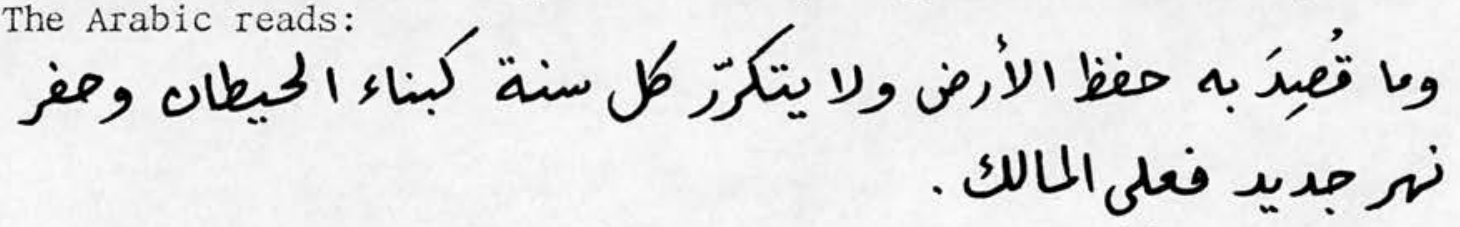

To make sense of the expression mä qusida bifz al-aş, the mä surely has to be interpreted as being the subject of the verb Ta yatakarrir as well as that of qusida, whereas Van Den Berg treats each half of the sentence as, effectively, a separate sentence: "tout ce qui sert à conserver les arbres eux-mêmes, et tout travail qui ne se répète pas chaque année ...". What, one feels like asking, can possibly constitute "everything which serves to maintain the trees themselves", if not those very things which are not repeated annually and of which al-Nawawi gives two examples? The present writer's translation eliminates this difficulty. 
pay another person to complete the work, if, that is, he ever wants to be recompensed by the original tenant.

If the tenant dies during the period of the contract, the procedure is simple: his heirs must complete his part in the contract, either personally themselves or else by hiring someone to do it for them.

If the tenant in some way breaches the contract, then someone can be appointed to keep a watch on him, and if this produces no improvement, then the tenant can be replaced.

Finally, if the fruit is removed for some reason before the tenant has received his proper share, then he has a right to be compensated by being given an equivalent wage in lieu.

\subsection{Discussion}

Unlike al-Shäficî, al-Nawaw $\overline{1}$ gives no initial definition for the musaqāh, and it must be presumed that any reader of the work will know that the term refers to sharecropping for a share of what the land produces. Further, al-Nawawi provides no indication at all of how large or small shares may legitimately be, whereas al-Shäfic $\bar{i}$ does at least give examples of one-third and one-half. Such knowledge may also be assumed on the part of al-Nawawi's readers, as a result of what must have been extensive discussion among Islamic lawyers of the subject in the four and a half centuries between al-Shäficī's time and that of al-Nawawì.

Also resulting from these intervening centuries is a notable development in the Shäfici theory of what is valid and what invalid in sharecropping, and al-Nawaw' 's formulation of this is much more detailed and specific than that of al-Shäfici. In particular, the distinction has been made by al-Nawawi's time between a stand-alone muzāracah contract, which, like the mukhäbarah, is always invalid, and the valid muzāracah which must be dependent on a musāqāh contract. No hint of such a distinction is to be found in the Kitäb al-Umm, as has been seen. Indeed, it has been asserted more generally that the real founders of the developed Shäfici School owed very little to the writings of al-Shäfici himself. For example, E. Chaumont says that the figh work a7-Mukhtasar of Abu 
Ibrāhīm Ismācīl bn Yahyā al-Muzanī (175/791-264/878), a disciple of al-Shäfici, "has definitely greater importance than the Kitāb al-Umm of al-Shāficī himself in the development of Shäfici doctrine", and it is surely significant that even al-Nawawi does not mention any of the works of al-Shäfic $\bar{i}$ in a list he drew up of works of fiqh which had exerted in his view the greatest influence in the development of the Shāficī Schooliss.

Al-Nawawi's chapter on sharecropping includes several other detailed statements on what conditions are required for a valid sharecropping contract, together with types of contract which are not valid. The invalid contracts include, notably, those which specify that the crop sharing is to be based on partition of the land, and also those in which the sharecropper has to plant the trees himself in the first place (that is, a mughärasah contract, though al-Nawawi does not mention the term). Further, there are specific injunctions on what procedure should be adopted when a particular situation arises during the term of the contract such as the death or absconding of the sharecropper. In all cases, the statements and injunctions are much more detailed and specific than are found in the Kitäb al-Umm and may be seen as the result of the discussion which must have taken place as the nascent shäfici School of the late second/eighth century was transformed into the mature Shäfici School of the mid-seventh/mid-thirteenth century.

Al-Nawawi also gives the wording to be used to make a valid musāqāh contract, and, as has been remarked, the fact that it is essentially a verbal process will be shown to be significant when Yemeni contracts are considered in Chapter 8 (Section 8.3 below). It is interesting that al-Nawaw $\vec{i}$ states here that the details of the duties the sharecropper must perform do not have to be.declared at the time the contract is made, since they should be in accordance with local custom. He does however add his own list of these duties and moreover provides a practical criterion by which the duties of the sharecropper (those which recur annually) may be distinguished

is Chaumont EI²b, article "Al-Shāficiyya" :188b. 
from those of the landowner (those which do not recur annually). The duties mentioned in al-Nawawi 's list, and perhaps more significantly duties which one could suppose must exist but which are not mentioned (such as the duty of transporting the landowner's share of the harvest), will appear again in Chapter 8 when contractual duties in Yemeni sharecropping are examined in detail.

\subsection{Concluding Remarks on the Shäfic $\bar{i}$ Position}

The purpose of this chapter has been to put forward the view of the Shäfici School, the madhhab of the majority of Yemenis in the west, centre and south of the country, as it is found in the writings first of its founder and then of one of the most influential authorities of its developed phase. An indication of how the viewpoint was elaborated in the period of over four centuries between the two authorities has been suggested in the discussion in Section 4.33 above. Nevertheless, the basic tenet on sharecropping held by the School, which al-Shäficī himself held, can be put simply enough: the musāaah contract is the only type which is valid. The later development of the principle, which shows in al-Nawawi's chapter, is that a muzāracah contract can also be valid if, but only if, it is made as an integral but subordinate part of a musāqāh contract. All other forms, including the mukhābarah, the mughärasah and the free-standing muzäracah, are theoretically invalid for Shäficiss. As will be shown however in Part II of this thesis, all forms of sharecropping are found in practice all over the Yemen, even in predominantly Shäfici areas, and, moreover, an otherwise unimpeachable Shäfici source to be quoted in Chapter 8 (Section 8.32 below) will be seen to aid and abet the "un-Shāficī" practices by providing models on the basis of which muzāracah and mughärasah contracts can be drawn up.

The theoretical Shäfici stance to the contractual relationship of the parties in sharecropping is clearly demonstrated in the choice of terminology both al-Shäfic $\overline{1}$ and al-Nawaw $\bar{i}$ use, and in particular the term employed for the sharecropper, which, with the single exception of one use by al-Shäfic $\bar{i}$ of the term musāq $\overline{7}$, is always câmit. In most cases, the cámil is hired by the landowner - 
that is to say, the landowner does the hiring. Occasionally, the camil hires himself out to the landowner. But the sharecropper is never called an aj $\overline{7} r$ or some other word meaning tenant and still less is he a sharik a partner with the landowner. This usage of cāmil for the sharecropper is reflected, as was seen in Chapter 3 (Section 3.55) above, in the Yemeni Civil Code al-Qanün al-Madan̄̄ in the case of musāqāh, though in the shāfic $\overline{1}$ works discussed in this current chapter the same term $c \bar{a} m i l$ is retained even when muzāracah and what is evidently mughärasah are being discussed.

Such then are some important aspects of the Shäfici theory of sharecropping. It is now time to examine in similar detail how the other major School of the Yemen, the Zaydis, views the subject, and this is the aim of the next chapter, Chapter 5. As will be seen, although the Zaydi authorities frequently quote Shäfici scholars, their legal view of sharecropping differs fundamentally in several ways. 


\section{CHAPTER 5 : THE ZAYDI POSITION ON SHARECROPPING}

5.1 Introductory Remarks

5.2 Ibn al-Murtadā on Sharecropping in a7-Babr a 7-Zakhkhār 5.21 Ibn al-Murtadā

5.22 Observations on the Text of a7-Babr a7-Zakhkhär

5.23 A Synopsis of the Kitāb al-Muzāracah with Comments 5.24 Discussion

5.3 Al-Shawkānī on Sharecropping in the Nayl al-Awtär

5.31 Al-Shawkānī and his Nayl al-Awtār

5.32 A Synopsis of the Kitāb a7-Musāqāh wa-a7-Muzāracah with Comments

5.33 Discussion

5.4 Concluding Remarks on the Zaydi Position 


\subsection{Introductory Re-arks}

In contrast to the viewpoint of the Shäfic $\bar{i}$ School which has adherents across the Islamic world from Egypt to south-east Asia, the Zaydi School is restricted geographically nowadays to only the northern parts of the Yemen ${ }^{1}$. Partly as a result of this, Zaydi opinions are perhaps less well known than those of the Shäficiss. It is the purpose of this chapter to examine in some detail the Zaydi approach to sharecropping by focusing on the writings of two of the School's principal proponents: in Section 5.2, al-Mahdī li-Dīn Allāh Ahmad bn Yahyā al-Murtadā (d. 840/1437) and his a1-Bahr a 1-Zakhkhār; and in Section 5.3, Muhammad bn ${ }^{c} A 1 \bar{i}$ al-Shawkāni (d. 1250/1834) and his Nayl al-Awtär. As will be seen, the two texts are different in nature and purpose.

\subsection{Ibn al-Murtadā on Sharecropping in al-Bahr al-Zakhkhār}

\subsection{The Imām Ibn al-Murtadā}

The Yemeni Imām al-Mahdī li-Dīn Allāh Abmad bn Yahyā bn al-Murtad̄ā, usually referred to simply as either al-Mahdi or Ibn al-Murtadā, is without doubt one of the most respected and we11-known authorities on the Zaydi School of Islamic Law2. His genealogy, which includes some of the most eminent Zaydi Imāms of the Yemen, can be traced back through some twenty-four generations to ${ }^{c} \mathrm{Al} \bar{i}$ bn $\mathrm{Ab} \bar{i} \mathrm{Ta} l i b$ and is given in full by the editor of al-Babr al-Zakhkhär in his Preface to the $1394 / 1975$ published edition ${ }^{3}$.

1 The only other Zaydi "state" (if it can be called such) ever to have existed was the small Zaydi Imāmate of Tabaristān, south of the Caspian Sea. It lasted in some form or other from the second half of the third/ninth century until it finally collapsed early in the sixth/twelfth century. 
Ibn al-Murtadā was born near the town of Dhamār, some 60 miles $(100 \mathrm{~km})$ south of $\mathrm{San}^{\mathrm{c}} \overline{\mathrm{a}}$, on the high plateaux of northern Yemen. The most commonly accepted year of his birth is $764 / 1362^{4}$, when the Rasūlid state had been flourishing in Lower Yemen for well over a century. Orphaned in his early childhood, he was instructed in religious studies under the guidance first of his educated elder sister at Thulā, some 25 miles $(40 \mathrm{~km})$ north-west of Sanc'a', and then of several male members of his family including his maternal uncle the Imām al-Mahdī li-Dīn Allāh ${ }^{c} A 1 \bar{i}$ bn Mubammad bn ${ }^{c} A 1 \bar{i}$ (d. 773/1369). During this time he came under the influence of some of the most distinguished and learned Zaydi thinkers of the day 5 .

On the death of the Zaydi ruler the Imām al-Nāsir Salāh al-Dīn Mubammad bn al-Mahdi ${ }^{c} A 1 \bar{i}$ in $793 / 1390$, when Ibn al-Murtadā had reached the age of 28 , many of the Zaydi culamā' nominated him to succeed as Imām with the regnal title al-Mahdi 1i-Dīn Allāh, in preference to al-Naşir Salāh al-Dīn Muhammad's son 'Alī. cAlī however declared himself Imām with the title al-Manşūr. A battle ensued between the supporters of the two rival imäms which resulted in the victory of al-Manşūr and the imprisonment in $\operatorname{San}^{c} \bar{a}$, of al-Mahdī Ibn al-Murtad̄a together with several of the 'ulamā' who had backed him. Ibn al-Murtadā remained in prison for seven years from $794 / 1391$ until 801/1398 during which he wrote several religious and

2 Because in Yemeni history several imāms took the title al-Mahdi li-Dīn Allāh, Abmad bn Yahyā al-Murtadā will be referred to here as Ibn al-Murtadā. The main secondary sources on which the following background information on the life and works of Ibn al-Murtadā has been based are: the Editor's Preface from the 1394/1975 Beirut edition of Ibn al-Murtad̄a al-Babr al-Zakhkhār (:I, 15 ff.); al-cAmrì 1992a; Eagle 1994; Brockelmann 1937-49, Geschichte :I, 187 and Supplement :II, 244-245; and Strothmann EI (Article "Al-Zaidiyya").

3 Ibn al-Murtad̄a al-Babr al-Zakhkhār :I, 15.

4 According to the editor of the 1394/1975 Beirut edition of al-Bahr a7-Zakhkhär (:I, 15), al-Shawkāni estimated the date of Ibn al-Murtadā's birth as approximately $775 / 1373$ and others have followed al-Shawkānī's reckoning. However, both that editor and Husayn al-cAmri (1992a :I, 66a) give the date as 764/1362.

5 Ibn a1-Murtadā a7-Babr al-Zakhkhār, Editor's Preface :I, 16-18. 
other works, including the Matn al-Azhär fi Fiqh al-A'immah al-Athār referred to below.

Soon after his release from prison he took refuge first at Thulā and then at $\mathrm{Sa}^{\mathrm{c}}$ dah (some 125 miles $\left(200 \mathrm{~km}\right.$ ) north of $\operatorname{San}^{\mathrm{c}} \overline{\mathrm{a}}$ ') . There, in $816 / 1413$, he finally renounced his claims to the Zaydi imamate and devoted his efforts for the remainder of his life to a jihād, not now against the Imām al-Manşūr, but against "al-jahl wa-al-bide wa-a7-daTaTat" (ignorance, innovation and error) ${ }^{6}$. He died in a plague epidemic in $840 / 1437$, an epidemic which only two months later also caused the death of the Imām al-Manşūr.

Ibn al-Murtadā left behind him a large corpus of works not only on religious matters (ușül, fiqh, tafsīr, badith, zuhd) but also on the science of language, logic and history ('uTum al-lughah, mantiq, ta'rikh). The editor of the $1394 / 1975$ Beirut edition of al-Babr a7-Zakhkhär lists 33 titles of works by him, six of which have been published and several others of which are incorporated in al-Babr al-Zakhkhār itself ${ }^{7}$.

Probably his two best known works of figh (Islamic jurisprudence) are the Matn al-Azhär fi Figh al-A'immah al-Athär and the Kitāb al-Abkām min al-Babr al-Zakhkhār al-Jäic 1i-Madhāhib cUlamā' al-Amsār fị Sá'ir cUTum al-Ijtihād, which are generally referred to by their abbreviated titles al-Azhär and a7-Babr al-Zakhkhär respectively. Both have appeared in published form. The former, a7-Azhār, which Ibn al-Murtad̄a wrote while imprisoned in Sanc $\bar{a}$, , is a wide-ranging overview of Zaydi fiqh based on the work a)-Intişar of Ibn al-Murtadā's great predecessor the Imām al-Mu'ayyad bi-Allāh Yahyā bn Hamzah bn 'cAlī (669-749/1270-1349) . Because of its importance as a fundamental text of the Zaydi School, many commentaries on al-Azhär appeared in subsequent centuries ${ }^{8}$.

$6 \quad$ Ibid., Editor's Preface : I, 20.

7 Ibid., Editor's Preface : I, 21-23.

8 R. Strothmann ( $E I^{1}$, Article "Al-Zaidiyya") has called it "the official textbook of the present day Zaidi state". Al-cAmri 1992a (:I, 96a-b) lists several of the extant commentaries on a7-Azhär. 
His other great figh work, al-Babr al-Zakhkhär, has also been influential in shaping Zaydi jurisprudence and is of ten cited. The work is in two parts: the Muqaddimah (Introduction), and the Fas 7 al-Abkäm (the section dealing with the regulations of the law). Several Mss. of the work exist' ${ }^{9}$ and a published edition appeared in 1368 [/1948], though the text in this edition was incomplete since it lacked the Muqaddimah'10. An edition of the complete text and incorporating a commentary on it called Jawähir al-Akhbār wa-a1-Athār a1-Mustakhrajah min Lujjat a1-Babr a1-Zakhkhār by Muhammad bn Yahyā Bahrām al-Sacdī (d. 957/1549) was published in 1394/197511. It is this edition which has been used for the present study. As far as is known, no translation of the text into a European language has ever been published.

\subsection{Observations on the Text of a1-Bahr a7-Zakhkhär}

That the text of al-Babr al-Zakhkhär should present difficulties for anyone but a Zaydī legal scholar to understand fully, and still more for a translator to render into English, is not surprising. It is true that it is written in grammatically correct (if somewhat abbreviated) fushā (Standard Literary Arabic) with few if any dialectal usages. However, as the editor of the 1394/1975 Beirut edition remarks in his Preface, Ibn al-Murtadā was writing "basically for experienced 'ulamā' and not for beginners just learning"12. The difficulties presented by the text are partly

9 Brockelmann 1937-49 :Supplement II, 245.

10 Ibn al-Murtad̄̄ a7-Babr al-Zakhkhär, Editor's Preface :I, 8.

11 Ibn a1-Murtadā al-Babr al-Zakhkhār. A1-Sacdī's Commentary consists (at least in the Kitāb al-Muzāracah) only of the expansion of the badiths.

12

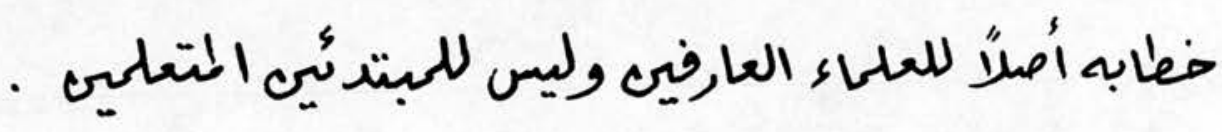

"khitāb-hu aşan 1i-al-culamā' al-cārifin wa-laysa 1i-al-mubtadi 7 in a1-mutacallimīn" (Ibn al-Murtad̄a al-Babr al-Zakhkhār, Editor's Preface : I, 9). 
grammatical, partly terminological and partly stylistic.

Grammatically, a major problem is (as often in Arabic) the

assignment of pronouns to their antecedents, though the meaning will no doubt be obvious to the Zaydi legal authority. Terminologically, the interpretation of certain expressions can sometimes lead to different readings. For example, a simple word such as al-zarc can mean "(the act of) sowing" or "the grain" or "the standing crop" and the choice of the word in the translation will affect the meaning (as for example in lines 2-4 on p.65 of the Arabic text). A more critical difficulty however is the stylistic one. The text is written in what might be called a "legal shorthand": the author is confident that the $\overline{q a} \bar{d} \overline{7}$ or faqīh reader will easily supply whatever is not explicitly stated.

Throughout the published text of the 1394/1975 Beirut edition of al-Babr al-Zakhkhār, quoted authorities are almost invariably referred to by a set of abbreviations enclosed in parentheses. These abbreviations are apparently found in Ibn a1-Murtadā's original text13. The key to the abbreviations is given by the editor at the end of the final volume14. In the seven pages devoted to the Kitāb al-Muzāracah some thirty-two different abbreviations are used representing as many different authorities. Several of the abbreviations represent Companions of the Prophet and the Successors, as transmitters of badiths, including:

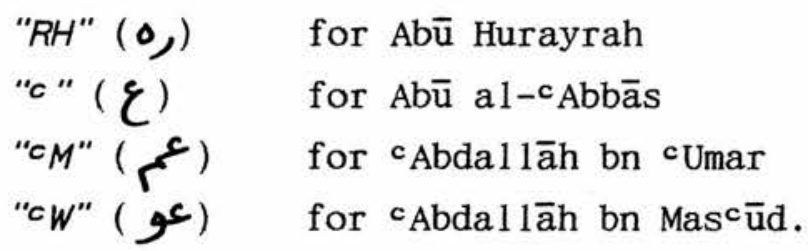

Others, as might be expected for the Zaydis, are direct descendents of ${ }^{c} \mathrm{Ali}$ bn $\mathrm{Abi}$ Tàlib. Of these the most frequently mentioned are:

13 Ibn al-Murtad̄a al-Babr al-Zakhkhār, Editor's Preface :I, 9.

14 Ibid. :VI, 571-573. 


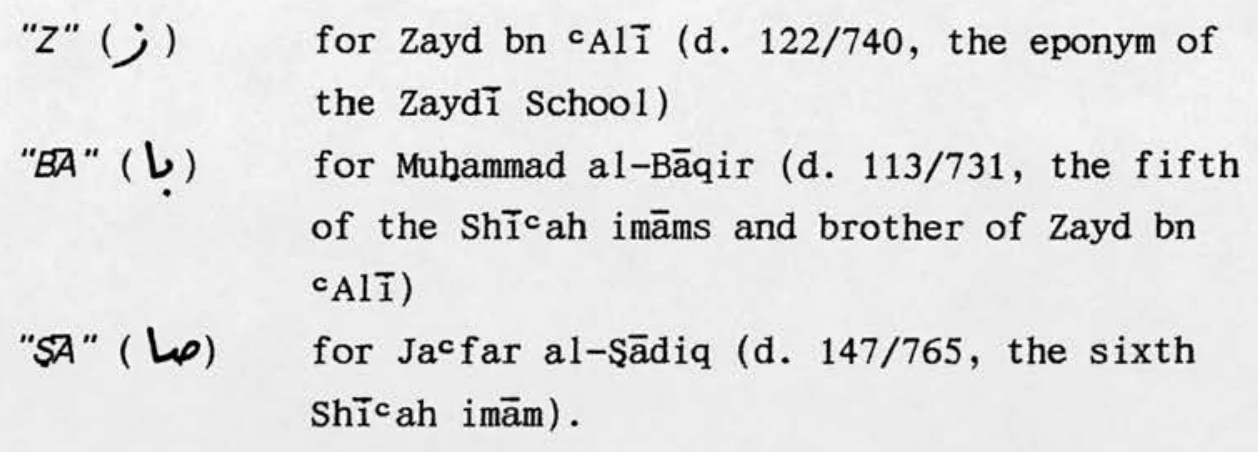

Also mentioned frequently are several of the Zaydī imāms who ruled in the Yemen. Of these latter the following are by the most commonly quoted by Ibn al-Murtadā:

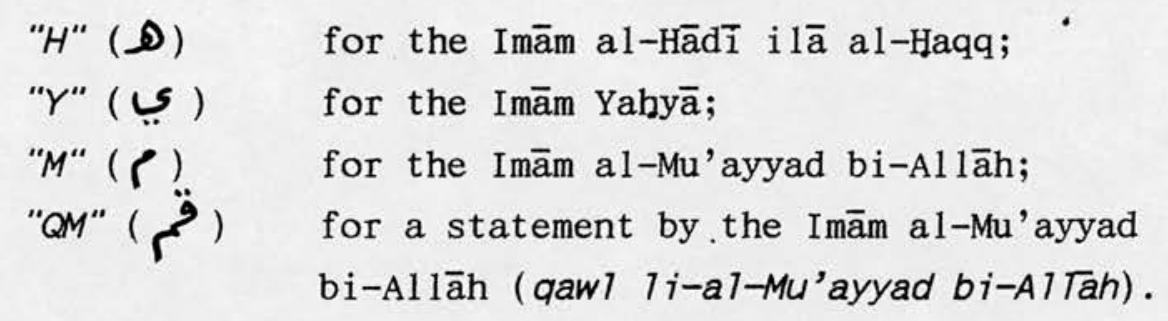

Unfortunately, the precise identification of these three Zaydi imāms is difficult. Before Ibn al-Murtad̄a's time there were at least three ruling imāms who had the name Yahyā, and as if to increase the difficulty, two of these Yahyās took the regnal title al-Hādi ilā al-Haqq, while the other Yahyā adopted the title al-Mu'ayyad bi-Allāh. Among the most likely contenders are:

al-Imām al-Hādī ilā al-Haqq Yahyā bn al-Husayn bn al-Qāsim, d. 298/910, the founder of the Yemeni Zaydi state, whom al-Shawkānī also quotes ${ }^{15}$;

al-Imām al-Mu'ayyad bi-Allāh Yahyā bn Hamzah bn 'Alī, d. 749/1349, already mentioned in Section 5.21 above as author of a work on which Ibn a1-Murtadā based his own al-Azhār, and a near contemporary with Ibn al-Murtadāi ${ }^{16}$.

15 See Eagle 1994; and al-cAmrī 1992b:II, $1018 \mathrm{~b}$. 
Ibn al-Murtadā also uses the abbreviation "HB" ( ) to mean "al-Madhhab" (that is to say, the Zaydi School) when he is detailing the view of his own School more generally. In addition, however, he is notable for quoting extensively the opinions of the four Sunni Schools, the authorities of which he abbreviates as follows:

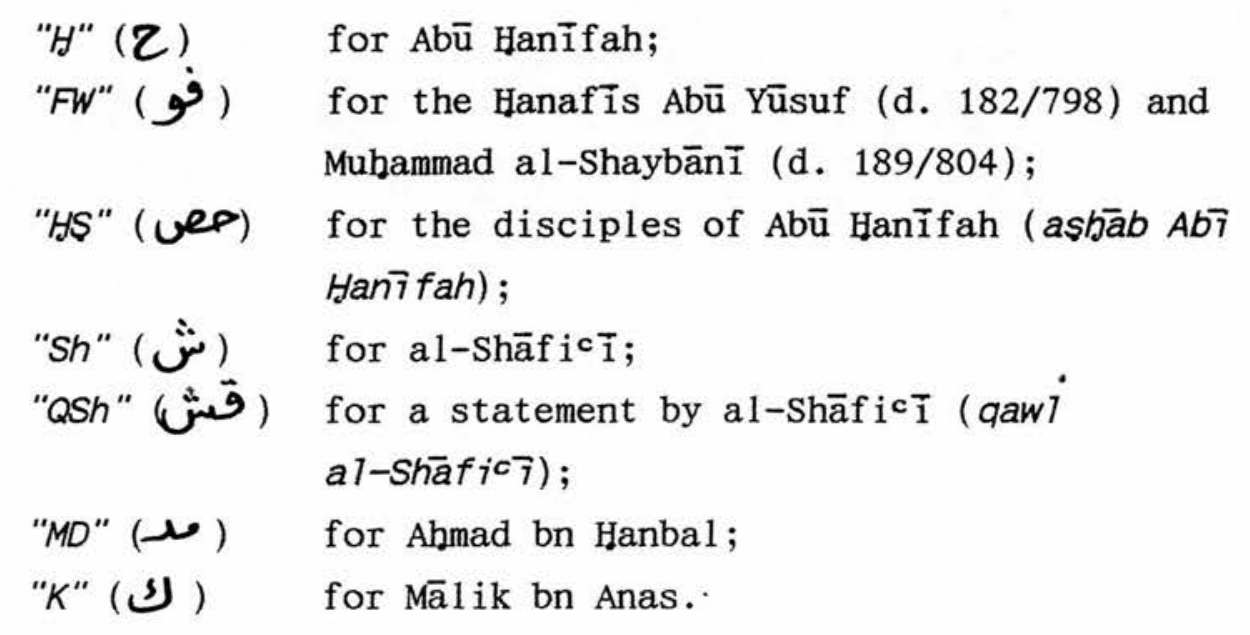

The Kitāb al-Muzāracah of a1-Bahr al-Zakhkhār is divided into three main parts. The first concerns sharecropping contracts on sown land (that is to say, muzāracah contracts proper); the second covers contracts on land with perennial crops and is entitled Báb al-Mughärasah; and the third deals with contracts in irrigated perennial crops with the title Bäb al-Musāqāh. Within each of these parts, the word fasl divides major sections and could be translated "Section". The sections are sometimes split into subsections by the word farc in parentheses.

As is usual in works such as this, each new question or topic is introduced by the word mas'alah (in double parentheses) which occurs 25 times in the Kitāb al-Muzāracah and could be. translated "Issue".

As we 11 as the use of parentheses in the cases mentioned above, quotations from the Qur'ān and the badiths are enclosed in double

16 See al-cAmri 1992c :II, 1019. 
parentheses, but these, like the occasional use of commas, colons and full-stops, are likely to be editorial.

\subsection{A Synopsis of the Kitäb al-Muzäracah with Comments}

(a) The Muzāracah Proper $(: 64-65)$

i) General conditions for the validity of muzäracah (:641-12): Ibn al-Murtad̄a opens the Kitāb al-Muzāracah with a statement of the general conditions under which a muzäracah contract is valid, muzāracah being not only a general term for a sharecropping contract but more specifically a sharecropping contract which involves annually sown crops, typically grain crops. As has been seen above (Chapter 4, Section 4.22), al-Shāf $i^{c} \bar{i}$ also employed the term with both its general meaning and its specific meaning.

Ibn al-Murtadā states that for the muzāracah to be valid it must be regarded as a contract in which the land is held in common (shiyāc) as a joint holding (mushāa) by both parties who then share the harvest as joint owners, and it cannot be considered as a contract in which the tenant's share of the harvest is the wage for the labour he has expended. Ibn al-Murtadā's terminology reflects this view: the tenant is a muktari or a musta'jir or an ajpr, while the leasing is indicated by the verbs akrā, ajjara and ista'jara ${ }^{\mathbf{7}}$. The following translates his opinion:

I would say: The correct judgement is that leasing land held in common ( $t a^{\prime} j \overline{7} r$ al-mushäc) is valid when both [parties] divide [the harvest] among themselves as two owners would; but leasing is not valid [when the rent is calculated] on the basis of the labour [involved] in producing [the harvest], since [in this case] the tenant ( $a j \overline{7} r$ ) would be obliged to labour as a consequence of the contract - which is impossible when land is held in common. It would be as if he were being hired against something he were unable [to deliver] in the circumstance. 18

17 This is, of course, a radically different approach from that held by al-Shäfici $\overline{1}$ and al-Nawawi where the "tenant" is a mere cämi 7 and there is no question of the land being held in common as a joint partnership, as was seen in Chapter 4 above. This will be commented on below. 
Ibn al-Murtad̄a then adds that according to the Zaydī Imām Yabyā, a muzāracah contract would also be valid if half a piece of land is lent to a tenant in return for the latter's labour on the other half, or else half his labour on the whole land, and he supports this view by saying that a contract in which the supply of the seed to be used over the whole land is shared by both parties would also be valid. A situation in which a muzäracah contract would not be valid, however, is where the rent would be a share of the crop harvested from some other piece of land not included in the contract. 19

He then points out that certain named ${ }^{c} \mathrm{Alid}$ authorities, together with the Hanafís Abū Yūsuf and Mubammad al-Hasan al-Shaybānī, have allowed the muzāracah on the basis of a share of the harvest paid as wage or rent, their justification being the deal the Prophet allowed the Jews at Khaybar - and here al-Sacdi's commentary expands the Khaybar bad 7 th in ful120. Ibn al-Murtadā at this stage reserves judgement on this view, saying only quinā

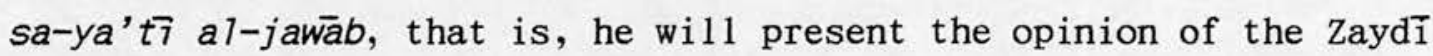
madhhab later.

ii) Relations with dhimmis in land contracts (:6413-17):

Ibn al-Murtada's next concern is the status of Dhimmis (Jews and Christians) in muzäracah contracts and in contracts involving land more generally. He states first of all that engaging a dhimm $\overline{7}$ as a tenant in a muzäracah contract is valid, because of the Prophet's deal with the Jews at Khaybar. However, according to several authorities whom Ibn al-Murtadā names and who include the

\section{Ibn al-Murtađ̄ā a 7-Babr a 7-Zakhkhār :V, 644-6.}

19 What is being put forward here is the legitimacy of a contract in which the land is partitioned into plots and the share of the harvest for the two parties is gathered from a different plot, with the sole proviso that all the plots be included in the contract. It will be remembered from the previous chapter (Chapter 4, Section 4.32) that al-Nawaw $\overline{1}$ specifically prohibited this kind of sharecropping contract.

20 The relevant bad7 ths were discussed above in Chapter 3 (Section 3.32). 
Zaydī Imāms Yahyā and al-Hādī, it is invalid for a Muslim to sell agricultural land to dhimmis because, he states, the cushr (tithe $\operatorname{tax}$ ) would thereby be reduced $\mathbf{2 1}$. Although he then quotes also the opposite view held by other authorities (that land, like chattels, can be sold to dhimmis), he declares that the Zaydi opinion is that land sales to dhimmis are not permitted, adding that according to the Imām Yahyā, if any such sales take place then they must be annulled and the money returned to the dhimm $\overrightarrow{7}$ buyer, and that if the Muslim seller refuses to return the money recourse must be to the imām.

A question of interest emerging from this section is why Ibn al-Murtadā should mention dhimmīs at all. That he should devote a passage to the status of dhimmis in agricultural contracts suggests one of three possibilities, all of which are probably to some extent correct: either dhimmis were sufficiently numerous in the Yemen around $800 / 1400$ to warrant such a discussion; or that he included the discussion only for historical and academic reasons, following the texts of the earliest phases of Islam; or else that he was writing for a wider Muslim audience than the Zaydis of Yemen.

iii) Defaulting tenants (:6417-652):

The question which Ibn al-Murtadā deals with next concerns a defaulting tenant, and he states the position briefly. Following the view of the Imām al-Hādī, Ibn al-Murtad̄a asserts that a tenant must carry out the work he is contracted to do and if he defaults he is not entitled to any return.

21 Concerning the sale of land by non-Muslims to Muslims, Yahyā bn Adam in his Kitäb a7-Kharaj gives this same reason for their prohibition - that is, the reduction in the khara $j$ land tax which results from such sales. However, he states also that to overcome the problem, the land itself can be declared subject to kharäj, irrespective of the status of the person owning it. See Ben Shemesh 1958 (:I, 15), and also Haque 1977 (especially 196-97, 217, 267, 291-92, 294) for the cushr tax; and Løkkegaard 1950 for the difficulties of terminology of the various taxes in the early Is lamic empire. 
iv) The supplier of the seed and the owner of the crop (:652-4):

The next issue, which concerns the relationship between the party who supplies the seed and the party who does the sowing and which of them should be the owner of the harvest, is similarly dealt with briefly, though the point being made by Ibn al-Murtadā, again following al-Hādi, is not entirely clear. It would seem to be that the party who does the sowing should be the owner of the harvest and then that he would give the landlord a share of it as rent.

v) Cultivating land belonging to orphans and waqf (:654-17):

There then follow several points concerning inalienable land belonging to orphans or a waqf (religious endowment). Concerning first the question whether it is valid for someone to cultivate such land under a sharecropping arrangement, Ibn al-Murtadā presents two views. According to the Zaydī Imāms al-Hādī and al-Mu'ayyad, such cultivation would be valid if it is in the interests of public benefit and not solely in the interests of the cultivator himself. According to other authorities, however, the cultivator would be a usurper unless he is acknowledged to have legal trusteeship. Ibn al-Murtad̄a sides with the latter view.

The second point here concerns whether a formal contract is necessary in such cases, and again Ibn al-Murtadā cites two points of view. According to the Imām al-Hādī, if the cultivator observes the true owner's rights in the ownership of the harvest, then no formal contract is necessary. According to the Imām al-Mu'ayyad, however, a formal contract is essential, and draws an analogy with contracts of sale, a point of view with which Ibn al-Murtadā concurs.

The third point in this section concerns who should preside over the drawing up of such a contract if no imām is available. Here Ibn al-Murtadā states that according most authorities, including the Imāms Yahyā and al-Hādi, the contract should simply be drawn up before the most fitted person.

Ibn al-Murtadā's fourth point on this subject is to do with the case where a cultivator of land belonging to an orphan or a waqf knows that a legal trusteeship would be desirable but nevertheless 
goes ahead without one. Again, Ibn al-Murtadā gives two opposing views. According to three Zaydī imāms (Yahyā, al-Hādī and al-Mu'ayyad), knowledge about the most desirable procedure does not affect the validity of what the cultivator does. According to other authorities however, if the party concerned believes that a legally acknowledged trusteeship is advised, then the arrangement would be invalid without one. Ibn al-Murtadā sides with the latter view.

To this last point Ibn al-Murtadā adds a view of the Imām Yahyā: if all parties agree, then even if they are acting in ignorance of the proper form the arrangement will remain valid, as it would in the same circumstances with a commercial transaction. Ibn al-Murtadā however has reservations about this view on the grounds that ignorance cannot deflect responsibility.

This concludes Ibn al-Murtad̄à's discussion of the muzāracah, and he now passes on to consider the mughärasah, the sharecropping contract in which perennial crops are involved.

(b) The Bäb al-Mughärasah: (:66-68)

i) General considerations for the validity of the mughärasah $(: 661-2):$

Ibn al-Murtadā begins his section on the mughärasah by saying that it is made valid in the same way as the muzaracah is made valid, and that the controversy about it lies in the fact that it is based on a share of fruit from a future harvest in the same way that the muzāracah is based on a share of grain from a future crop.

He then defines more closely the conditions under which the mughärasah contract is valid. These conditions concern the permitted types of crop and the specification of the plantation in question, the period of tenancy, the conditions under which the tenant will work, and the stipulation of the rent.

ii) Valid and invalid crops $(: 662-7)$ :

Ibn al-Murtad̄a states that, according to the Imām Yahyā, the mughärasah is valid only in the case of "trees with established trunks like date-palms and grape-vines", but not with annually-sown crops such as grain and vegetables $\mathbf{2 2}$, nor even with trees which are grown for their leaves rather than their fruit ${ }^{23}$. The justification 
he gives for this is a badith relating that "the people of the Hijāz work in date-palms", as so by analogy other plants which like datepalms have established trunks and are grown for their fruit can be included.

Ibn a1-Murtada then notes that there are two different opinions concerning whether trees which are not grown for their fruit can be the object of a mughārasah contract ${ }^{24}$. Following the Imām Yabyā, he says that the more correct of the two views is that the mugharasah is not valid with such trees since the badith on which the analogy is based (the deal the Prophet allowed the Jews at Khaybar) concerned only fruit-producing trees. Other authorities however (which he does not name) hold that it is valid to include such trees, since an analogy can be drawn between yielding timber and yielding fruit.

22 The crops he specifically excludes from the mughärasah are:

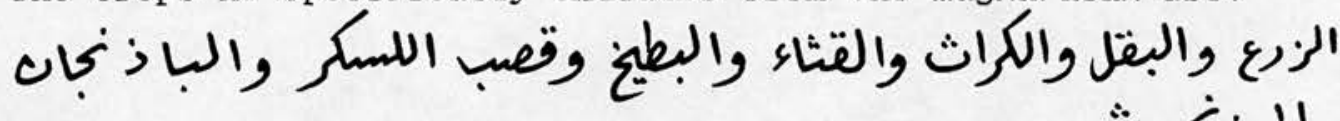

a7-zarc wa-a7-baql wa-al-kurrāth wa-al-qithä' wa-al-battīkh wa-qasab a7-sukkar wa-al-bādhinjān wa-al-marzanjush (grain, vegetables, leeks, cucumbers, melons, sugar-cane, aubergines and marjoram).

23 He cites here the example of a7-tūt a7-ahmar, "red" (i.e., black) mulberries. Presumably black mulberries were grown for their leaves, as food for silk-worms, although this is not mentioned. He goes on to say however that [a]-tüt] al-abyad, white mulberries, are allowed since it is their fruit rather than their leaves which are harvested. It must be inferred that silk-worms were not fed on white mulberry leaves, or at least that white mulberries, as opposed to the black variety, were not grown primarily for that purpose.

24 He gives here three examples of such trees: sayāl (species of acacia or mimosa, including Acacia seyal), tanab/tannub (Cordia abyssinica), and dharab (Ficus salicifolius). All of these are used for their timber. (See Jabali 1993:18 (for sayāl) and :49 (for tanab). Also: Piamenta 1990-91:167a, root $d h-r-b$, and $308 b$, root $t-n-b$; also Lane 1863-93 :959c, entry "dharah"; and Varisco 1982 :500.) 


\section{iii) Specification of the trees and the length of the lease}

$(: 669-14)$ :

Ibn al-Murtadā declares that the plantation which is to be subject to a mughārasah contract must be available for viewing, or else the trees in it must be described in detail in terms of their height and kind. Further, the period of the lease must be defined and that the shortest possible period is one year. Concerning the longest possible period, there are different views. According to some authorities (which he does not name) the maximum period is half the lifetime of a human being, which, because of a badith he cites here in abbreviated form and of which al-\$acdi provides fuller forms in his commentary, can be taken to be 30 years. According to other authorities (similarly unnamed), the lease period for property depends on the nature of the property concerned since different objects have different lifetimes: so, in the same way that a slave can be leased for sixty years, a beast of burden for up to twenty and a house for a hundred, a piece of land can be leased for 150 years, though some authorities add here that this period depends on the kind of tree growing on the land, date-palms having, it is asserted, the longest life.

iv) Conditions of labour $(: 6614-674)$ :

Ibn al-Murtada states that it must be made clear - presumably at the time the contract is agreed - what the tenant would be expected to contribute as far as digging, ploughing, irrigating and weeding are concerned. This would appear to be directly opposed to the view of al-Nawawi , mentioned in Chapter 4 (Section 4.32 above), that the work involved does not have to be detailed at the time the contract is made and that "what is not specified in any respect is to be referred to al-curf al-ghālib (the dominant custom)"25.

Ibn al-Murtad̄a then adds that, according to the Imām Yahyā, the tenant must be allowed to get on with his work without interference from the landowner who is entitled to enter the plot only to look round. The landowner has no right to insist that the tenant hire

25 Al-Nawawī Minhāj al-Tălibīn :II, $147 \mathrm{~s}$. 
extra labour to help him nor that he perform any service, such as working with a draught animal, which would be additional to his work in cultivating. If such conditions are placed on the tenant, then the contract is invalidated. Since the obligations of the tenant will be discussed later in this thesis (especially Chapter 8), a translation of the Arabic of this passage is given here in full:

It is necessary to announce [the conditions] of labour concerning digging, ploughing, irrigating and weeding. Because the labour on [the land] is the main concern, it is a condition that the plantation be handed over to the labourer without any sharing [of joint labour] so that he can get on with [his] work night and day, while the landowner has the [right of] entry only to look around, and that the tenant be left alone to do the work,. since it is not a condition that anyone else [must work] with him, nor is he obliged by any condition other than [to work] with the planted trees, such as [performing] a service [for the landowner] with a draught animal, as the effect on the contract would [in such cases] be to make it invalid. If a condition were to be placed upon [the tenant] that he hire someone to work with him, [the mughärasah contract] would be defective, since forcing him [to do this] would be invalid.26

\section{v) Stipulation of the rent $\left(: 67_{4-7}\right)$ :}

For his next condition for validity, Ibn al-Murtadā cites not only the view of his own Zaydi madhhab but also that of the followers of $A b \bar{u}$ Hanīfah and a statement by al-Shāficī. The point concerns the avoidance of an unknown quantity in the contract. Not only must there be information about the extent of the land under the contract and the trees on it, but the value of the rent must also be known. If the mughärasah is considered in terms of leasing for a rent to be paid as a share of an as yet unknown harvest then it would be invalid. Ibn al-Murtadā then adds it would be considered valid "only by those who maintain that the mukhäbarah is valid" (:676).

Concerning the matter of whether the plot of land must be viewed beforehand, he states further that some (unnamed) authorities

26 Ibn al-Murtad̄ā al-Babr al-Zakhkhār :V, 6614-674. 
allow a contract even when the land involved is not open to view, but that people prefer a situation when they can view it.

This then concludes Ibn al-Murtadā's discussion of the conditions under which a mughärasah contract can be valid.

vi) The wording to make a mughärasah contract $(: 677-8)$ :

He then indicates what wording a landowner may use to engage a mughārasah tenant. Like al-Nawawī's formulation for the musāqāh examined in Chapter 4 (Section 4.32 above), it is essentially a verbal process, with the emphasis on the words spoken.

The form [of words to make a mughärasah contract is for the landowner to say:] "Ghärastu-ka" ( I engage you as a mughärasah tenant); or: "cAmaltu-ka" (I make a deal with you [under a mughärasah contract]); or "Ighris hädhihi" (Tend this [piece of land] under the terms of the mugharasah). It is on this [basis] with the agreement [of the engaged party] [that a mughärasah contract would be valid], or some [wording] to the same effect.27

There then follows a section which covers a number of points concerning the duties of a mughärasah tenant, what happens in a case of trespass, what happens if either the tenant or the landowner dies during the period of the tenancy, and a number of other matters, some of which have already been touched on by Ibn al-Murtadā earlier.

vii) Duties of tenant $(: 679-10)$ :

Ibn al-Murtad̄a states that the mughārasah tenant has the duty to keep everything in good order basab a 7-muctād (according to what is customary), but tasks not directly to do with growing, tending and harvesting the crop are specifically excluded. The Arabic translates as follows:

It is the responsibility of the tenant under a mughärasah contract to keep things in good order according to what is customary, to repair the wells and channels and to clean the $j a \vec{r} \overline{7} n^{28}$, but not to build walls or purchase cows and similar jobs, [since these are] the responsibility of the landowner. 29 


\section{viii) Desertion of tenant (:6710-12):}

If a tenant deserts, the landowner is entitled to annul the contract and also to get an arbitrator (bākim) to assess any damages due to him as a result of the desertion. If there is no arbitrator available, then, Ibn al-Murtadā would seem to say, it is up to the landowner to do the assessment - though this last point is not completely clear.

ix) Trees alrteady bearing fruit (:6712-13):

Since a mughärasah contract must involve fruit which will ripen during the course of the contract in the future, there can be no mugharasah contract if the trees already bear fruit when the contract is agreed.

x) Death of tenant $(: 6714)$ :

A mughärasah contract is annulled if the tenant dies, since he will have been specified by name as the tenant. Ibn al-Murtad̄a here draws a parallel with renting a draught animal: if the animal dies, then the contract is annulled.

xi) Change of landownership (?) $\left(: 67_{14-15}\right)$ :

The next point is not entirely clear from the Arabic text. Perhaps the most likely meaning is that if the ownership of the land changes hands, then the mughärasah tenant has the right to annul the contract if he wishes to do so.

xii) Trespass $(: 6716-22)$ :

If someone plants or builds on a piece of land without the owner's permission, then Ibn al-Murtadā indicates that there are two points of view: either that any problems arising from the act are the responsibility of the trespasser and not the landowner, which is

28 The jarinn can be either the place where grain is threshed or the place where dates and grapes are dried (Lane 1863-93:414b-c). Comparable is mijran for a threshing floor in the southern Yemeni dialect (Landberg 1920-42 : I, 280 (entry j-r-n), and Serjeant 1974 :59). In Ibn al-Murtada's text however jarinn is more likely to mean the drying floor for drying dates, grapes and conceivably other fruit such as apricots, rather than a threshing floor, since this is a mughärasah contract in which grain does not figure.

29 Ibn al-Murtađ̄ā a7-Babr a7-Zakhkhār :679-10. 
the view he himself supports; or else that they become the responsibility of the landowner, which is the view upheld by the Imām al-Mahdī.

Ibn al-Murtad̄a continues that according to the Imām Yahyā, the landowner has the right to remove anything that has been planted or built on his land by a trespasser, even if by doing so he damages it. This may be done however only with the permission of an official arbitrator if one is available. Ibn al-Murtad̄a then gives his own opinion which is that it is certainly not wrong for the landowner to remove such articles, but that he should do it without damaging them if he can.

Ibn al-Murtadā adds that if the landowner consents to the trespass, the situation changes, since then there would be no trespass.

xiii) Death of landowner $(: 6722-684)$ :

As in the case of renting, a mughärasah contract will continue to be valid even if the landowner dies, and his heirs have no right to insist that the tenant uproots the trees he has planted under the contract or remove anything that he has built on the land. In such a case the tenant may choose between either pulling out his trees or demanding the value of them.

Ibn al-Murtad̄a then gives two conflicting points of view on the rights of heirs if a landowner who has leased land has fraudulently taken more than is legally his due and then has died before the mughärasah contract has expired. According to the Imām Yabyā and some of the Zaydi madhhab, and to Abū Hanīfah and his followers, the heirs in such a situation can cancel the remainder of the contract. According to al-Shäfici, however, the heirs have no such right, and it is this latter view with which Ibn al-Murtadā agrees. The reason he gives would seem to be as follows, though this passage is not entirely clear. It is the tenant who is the owner of the usufruct. If fraud is being claimed then the contract can be annulled only if the landowner is still alive.

xiv) Disputes over size of rent (:68s):

According to the Imām Yahyā, if the two parties to a mughārasah contract disagree on the amount of the rent to be paid, and there is 
no indisputable evidence to support one side over the other, they are both still bound by the contract. Ibn al-Murtadā adds that the situation is the same as it would be if the contract were a contract of sale.

xv) Provision of the tenant's materials and tools of trade $(: 686-8)$ :

Ibn al-Murtađā presents two opinions on whether a mughārasah contract is valid if it specifies that the tenant must provide his own materials, giving as examples here the plants and any stones necessary for building on the land. According to certain authorities, including $A b \bar{u}$ Hanīfah and his followers, and al-Shäfici, such a stipulation in the contract would not be valid, the reason given being that of gharar - the inclusion of something which has risk attached to it. But according to Mālik on the other hand it would be valid. Ibn al-Murtadā himself sides with the Hanafis and al-Shāfici for the same reason. of gharar, though he points out that there are some exceptions to the general rule which are allowed by $i j m \bar{a}^{c}$ (the consensus of jurists), such as the thread of the tailor, the paint of the painter and the ink of the copyist.

This concludes Ibn al-Murtadā's discussion of the mughārasah, and he now turns his attention to the musāqāh, the sharecropping contract involving irrigation, which forms the final section of the Kitāb al-Muzāracah.

(c) The Bäb al-Musāqāh $(: 68-70)$

i) General conditions for the validity of musāaāh $(: 689-10)$ :

As with the muzāracah and the mughärasah, Ibn al-Murtadā first gives the conditions for the validity of the musāqāh. The crucial point he makes here is that, as in the case of the mugharasah, information about the land and the trees must be available at the time the contract is drawn up.

ii) The validity of expressing rent in terms of future fruit $(: 6810-695)$ :

Ibn al-Murtadā gives the different views on whether the principle of expressing rent in terms of a part of a harvest which is to be produced in the future. According to some scholars, 
including $A b \bar{u}$ Haniffah and the Imām Yabyā, the practice is not legitimate. According to most authorities however (Ibn al-Murtadā quotes the names of seventeen scholars here) it is valid, adding that al-Shāficī restricted the practice to date-palms and grapevines. Ibn al-Murtadā then gives the view of his own Zaydi madhhab on this point. This is that a musāaanh contract is distinct from ijarah (leasing contracts), and so the question of quoting a rent or wage in terms of a future crop does not arise. His reasoning for this view relies on the interpretation of the Prophet's action at Khaybar. Rather than leasing the land to the Jews for a rent of half the produce, his action may be interpreted as either allowing them to keep half the produce for their sustenance, or else imposing on them the payment of half the produce as a jizyah tax (the capitation tax on non-Muslims). At each point during this discussion Ibn al-Murtad̄a refers to the appropriate bad7hths, which al-Sacdi expands in his commentary.

iii) Duties of tenant $(: 69 s)$ :

Ibn al-Murtad̄a disposes of this subject in one short sentence: the tenant $(a \overline{7} r)$ is responsible for keeping the irrigation channels (majāri a7-nahr wa-al-sayl) in good repair.

iv) The wording to make a musāaāh contract $(: 695-6)$ :

He then gives the proper form of words which may be used by a landowner to engage a musāqāh tenant, as he earlier did for the mughärasah, and again, as was seen with al-Nawawī in Chapter 4 (section 4.32), the emphasis is on the words actually used.

[The correct form to make] a verbal musāqāh contract is [for the landowner] to say: "Saqaytu-ka caTa hädhā al-nakhī 7 muddata ka-dhä" ( I engage you in a musāqāh contract over these datepalms for such-and-such a period), or words to the same effect such as "Tacahhad $\sqrt{7}$ hädhihi al-ashjär bi-al-saqy wa-al-is Tahb muddat ${ }^{2}$ ka-dhä" (Tend these trees for me by watering and maintaining them for such-and-such a period). ${ }^{30}$

30 Ibn a1-Murtad̄a, a1-Bahr a1-Zakhkhār, :69s-6. 
v) Supplementary labourers (696-8):

He indicates that the expense of supporting extra labour can lie on either party, according to the conditions stipulated in the contract. If the parties withdraw from the contract, then the question of whose responsibility it is to support the labourers is open to two different opinions. According to some (unnamed) authorities, it lies with the tenant, since he has the overall responsibility for providing the labour for the contract. According however to other authoritites (also unnamed), it is the responsibility of the landowner, on the grounds that the labourers are ultimately his servants. Ibn al-Murtada sides with the latter view.

vi) Rights in specifying the plot of land and the type of seed $(699-702)$ :

Quoting the Imām Yahyā, Ibn al-Murtadā says that the right to decide how much land to include under the musāqāh contract lies with the landowner, though the detail of the rest of Ibn al-Murtadā's meaning here and his reasoning behind it are not entirely clear $(: 6910-11)$.

What is much clearer however is Ibn al-Murtadā's next point $\left(: 69_{11}-70_{2}\right)$ which concerns the choice of the type of plant to be grown: according to the Imām al-Mu'ayyad, the right to choose lies "with the one who has his hand on the land" (that is, the tenant, since he does the farming), though according to the Imām Yahyā, the landowner may decide. Ibn al-Murtadā then gives his own view in a somewhat cryptic form: to paraphrase, "If there is a disagreement about whether an article is a garment (thawb) or a stocking (jirāb), those who say it is a garment must concede to the opinion of the one who has the stocking in his hand". This presumably means that the one who does the planting is best placed to decide what plants should be grown.

\section{vii) Disputes over size of rent:}

Ibn al-Murtad̄a gives two opinions about what should happen if a dispute about the size of the rent occurs. One view is that both parties should testify under oath to the amount, but others hold 
that the party who maintains the higher value should be taken to be correct. Ibn al-Murtadā sides with the latter view.

With this Ibn al-Murtadā concludes his discussion of sharecropping in its several forms.

\subsection{Discussion}

of the four figh texts chosen for detailed study in this chapter and the previous chapter of this thesis, that of the Kitāb al-Muzāracah from al-Babr al-Zakhkhär of Ibn a1-Murtad̄a is by far the most difficult. As was pointed out in Section 5.22 above, the work was written with Zaydi legal scholars in mind and makes no concessions to those who are not well-read in early figh. Although for the present writer several lacunae in comprehension remain, it has been possible to attempt to give, in the above Section, a detailed synopsis of most of the points Ibn al-Murtadā makes.

One feature of what Ibn al-Murtadā has to say on sharecropping is immediately apparent from the synops is given above: it is much longer and more detailed than the passages on the subject by either al-Shäfici or al-Nawawi $\bar{i}^{31}$. The greater length is partly accounted for by the range of questions taken up by Ibn al-Murtad̄a (sharecropping by dhimmīs on Muslim land, sharecropping on waqf land, provision of the tenant's tools of trade, and so on) which are not mentioned by either al-Shāfic $\bar{i}$ or al-Nawaw $\bar{i}$, and moreover, in contrast to the two Shāficī authorities, Ibn al-Murtad̄a covers all three Islamic forms of sharecropping contract; that is to say, not only musāqāh and muzāracah, but also mughārasah, a term not actually

31 Although admittedly a very imperfect measure, the number of lines of printed Arabic gives at least an idea of the length of the sharecropping passages in the various works. These are (excluding headings and subheadings which stand alone on their own lines): al-Shāf $i^{c} \bar{i}, 31$ lines; al-Nawawi , 49 lines; Ibn al-Murtad̄a, 97 lines. Al-Shawkānī's chapter on sharecropping in the Nayl al-Awtär, the subject of the next Section of this thesis (Section 5.3 below), is by far the longest of any of the four works under consideration, running to 284 lines, but, as will be seen, it is of a rather different nature from the others. 
used by either of the two Shäf $i^{c} \bar{i}$ s but used by Ibn al-Murtad̄a , only a century or so after al-Nawawi.

The greater length of Ibn al-Murtada's chapter is also however the result of the much greater number of authorities he quotes. It is notable that these authorities are by no means restricted to Zaydīs, even though the Imāms Yahyā, al-Hādī and al-Mu'ayyad are his most often quoted references. Also frequently cited are adherents of the four Sunnī legal Schools, including al-Shāfic $\bar{i}$ himself, and as has been noted in the synopsis given in Section 5.23 above, Ibn al-Murtadā of ten agrees with a Sunnī authority.

A number of points of disagreement between the Shāficis and Ibn al-Murtadā can be identified, and this is so despite the fact that all the authorities base their rulings ultimately on the same badiths, and especially the bad7ths relating the action of the Prophet at Khaybar. The most important difference is that, for Ibn al-Murtad̄a , not only are musāqāh contracts.valid, but also freestanding muzāracah contracts and mughärasah contracts - given, that is, certain stated conditions. Further, Ibn al-Murtadā's general attitude to sharecropping shows in the terminology he uses. Whereas with al-Nawaw $\bar{i}$ the engaged party is a mere $c \bar{a} m i$, a labourer, Ibn al-Murtadā refers to him as muktarī or aj̄̄r or musta'jir (all of which may be translated as tenant), and he employs the term $c \bar{m} i 7$ only in connection with the musāqāh contract. This same usage has already been seen in the Yemeni Civil Code, al-Qanūn a 1-Madan̄̄, discussed in Chapter 3 (Section 3.5 above).

Other differences exist between al-Nawaw $\bar{i}$ 's interpretation and that of Ibn al-Murtadā, but they are more minor, such as what should happen if a tenant dies during the period of the contract: for al-Nawaw $\vec{i}$ the death of a tenant means that his heirs become responsible for the completion of the contract; for Ibn al-Murtadā, however, the death of the tenant (in a mughärasah contract, at least) will mean that the contract must be annulled.

What is perhaps more surprising than the differences between the two Shäfic $\bar{i}$ authorities and the Zaydi Ibn al-Murtad̄a are the points they have in common. The words to be used to make a musāqāh contract, for example, are almost identical in the forms given by 
both al-Nawawi and Ibn al-Murtadā. Again, the lists given by both al-Nawawī and Ibn al-Murtad̄a of the duties expected of the tenant are very similar, even though the criterion each uses to define legitimate work is different: for Ibn al-Murtadā, the test is whether the work is integral to tending the trees, while for al-Nawawi, as was seen in Chapter 4 (Section 4.32 ), the criterion was whether the work recurred each year.

The point was made in Section 5.21 above that a7-Babr al-Zakhkhār is a fundamental work for Zaydī thinking. To what extent Ibn al-Murtadā's views on sharecropping are reflected in the writings of another, more recent, Zaydi authority, Mubammad bn ${ }^{c} \mathrm{Al} \bar{i}$ al-Shawkānī, is the subject of the next section.

\subsection{Al-Shawkāni on Sharecropping in the Nayl al-Awtar}

\subsection{Al-Shawkānī and his Nayl al-Awtār}

Muhammad bn ${ }^{c} A 1 \bar{i}$ bn Muhammad bn ${ }^{c}$ Abdallāh al-Shawkānī was born in $1173 / 1760$ in Sanc $\bar{a}$, hence his subordinate nisbahs al-Sancāni and al-Yamānī (also al-Yamanīi) ${ }^{\mathbf{3 2}}$. His father came from Shawkān in the province of Khawlān to the northeast of Sanc $\bar{a}$, where he was a Zaydi $\overline{q a} \bar{q}_{\overline{7}}$, an occupation he continued after moving to the capital Sanc $\bar{a}$ '. Al-Shawkānī showed his intellectual brilliance early in his studies of Islamic law in Sanc $\bar{a}$, and after he became a $\overline{q a} \bar{d} \overline{7}$ his fatwas came to be in demand not only in Sanc $\bar{a}$, but throughout northern Yemen. His life coincided with the rule of the three Zaydi Yemeni Imāms al-Mansūr cAlī bn al-Mahdī cAbbās (1189/1775-1224/1809), al-Mutawakkil Abmad bn al-Mansūr cAli (1224/1809-1231/1816), and al-Mahdī cAbdallāh bn al-Mutawakkil Abmad (1231/1816-1251/1835) ${ }^{33}$. It was the Imām al-Manşur ${ }^{c} A l i$ who appointed him to the office of Grand $\operatorname{Qad}_{7}{ }^{34}$, and in 1209/1794 at the young age of 34 he was given the title Shaykh al-Is Tam.

Before his death in $1250 / 1834^{35}$, al-Shawkānī had written more than two dozen books and essays on fiqh, tafsīr and other religious

32 The main secondary sources on which the following background information on the life and works of al-Shawkānī has been based are: al-cAmri 1992d; and Brockelmann 1937-49, Supplement :II, 818-19. 
subjects, several of which have been published, and also a diwant of poetry. Brockelmann lists 24 works by him and in addition a collection of his fatwas recorded by his son Abmad with the title

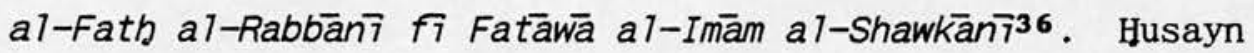
${ }^{c}$ Abdallāh al-cAmrīin mentions a few other titles by al-Shawkānī not cited by Brockelmann.

Probably the best known of his figh works is the Nayl al-Awtär min Abādj̄th Sayyid al-Akhyār [f]] sharb Muntaqā a7-Akhbār, of which there are at least two published editions: the 1297 (1878) Būlāq edition, and the 1973 Beirut edition ${ }^{38}$. The text consulted here is that of the Beirut edition of 1973. The chapter which concerns sharecropping in this edition is found in Volume VI, pp. 7-18, and is entitled Kitāb al-Musāqāh wa-al-Muzāracah. In this section there is as far as can be seen only one probable error (a7-mushmatilah for al-mushtamilah on p. 13 of the published text).

33 Some of the regnal dates of the Zaydi imāms in the late $12 \mathrm{th} / 18 \mathrm{th}$ to early $13 \mathrm{th} / 19 \mathrm{th}$ centuries are unavoidably open to differences of opinion, owing largely to the frequent periods when two or more claimants exercised control in different regions. (The regnal periods given by Bosworth (1967:72), for example, differ considerably from those given here.) For present purposes, al-Shamāhi (1985:169-170) has been relied on for the Hijri dates, which happen to coincide with the Christian dates given by Dresch (1993:201).

\section{Qãđi al-Qudāh wa-RaTis a1-Quđāh.}

35 Al-cAmri (1992d:828b) in the al-Mawsīcah al-Yamaniyah gives the year of his death as 1250/1834. Brockelmann (1937-49, Supplement :II, 818) also gives the Hijri year as 1250 (though this has been incorrectly converted to AD 1832 - see Spuler 1961). The title page of the 1973 Beirut edition of Nayl al-Awtär however gives the Hijri year of his death as 1255 (which would be $\mathrm{AD} \cdot 1839-40$ ).

36 Brockelmann 1937-49, Supplement :II, 818-19.

37 Al-cAmrī 1992d:829a.

38 Al-Shawkānī, Muhammad bn ${ }^{c} \mathrm{Al} \overline{\mathrm{i}}$ bn Muhammad, Nayl al-Awtār min Abādīth Sayyid al-Akhyār, (6 vols.) 1973, Dār al-Jī1, Beirut. Brockelmann (1937-49, Supplement : II, 818-19) gives a slightly modified title for the 1297 (1878) Būlāq edition: Nayl al-Awtär min Asrār [f̄̄ sharb] Muntaqā al-Akhbār. 
As is usual in a work of this period, punctuation is sparse. The quotation marks surrounding bad7ths, and the occasional full stops and colons are possibly editorial. Occasional stars and the letter hā' ه (standing for intahā, it has ended), which are devices of ten found in Mss. to mark the end of a quotation or a section, may however be original.

Apart from a few somewhat puzzling passages, al-Shawkānī's text is lucid and his material and arguments are logically presented and clearly explained, making the work considerably more approachable than al-Babr al-Zakhkhār of Ibn al-Murtadā. In the course of his discussion on sharecropping al-Shawkān $\bar{i}$ mentions by name some seventy persons. Most of these are readily identifiable as Aşāb (Companions of the Prophet), Tabicun (their Successors), the early collectors of badjiths (especially al-Bukhārīi, Muslim and Dāwūd), and the founders and early adherents of all four Sunni legal Schools. In addition, he cites at one point the views of the less well-known Zāhirī School. Al-Shawkānī refers also to five works in his sharecropping chapter. Of these, al-Qäüs and al-Umm are easily identifiable as al-Fīrūzābādī's lexicon al-Qämūs al-Muh̄̄ $t$ and al-Shāficī's Kitāb al-Umm respectively. A third, al-Musannaf, is likely to be the famous work by the traditionist Abu Bakr ${ }^{c} \mathrm{Abd}$ al-Razzāq bn Hammām al-Sancānī $(126 / 744-211 / 827)^{39}$, the teacher of Abmad Ibn Hanbal, since al-Shawkānī elsewhere cites cAbd al-Razzāq by name. The other two (al-IqTid and al-Fath) have not been identified.

As if to show his Zaydi credentials, al-Shawkān $\bar{i}$ always inserts wa-āli-hi (and his family) in the honorific formula following a mention of the Prophet used particularly by the Zaydis and other Shïcah sects: salTa AlTahu calay-hi wa-äli-hi wa-sallam (May God bless him and his family and grant him salvation). Despite this, he, like Ibn al-Murtad̄a, draws extensively on the views of the four Sunni schools of law (even though he does not always agree with them), and both of these Zaydi authorities could be seen perhaps as

39 See al-cAmrī 1992e :II, 633. 
specific validations of N.J. Coulson's assertion that Zaydi law is "a fusion of Sunnite and Shïcite principles"40. More than this, though, even to regard al-Shawkānī as a Zaydi may be misleading, since, as Brockelmann has declared, he did not restrict himself to any acknowledged madhhab $b^{\mathbf{1}}$, and it is certainly notable that, in at least the Kitāb al-Musāqāh wa-al-Muzāracah of the Nayl al-Awtār, al-Shawkānī does not cite a single Zaydī imām. While this omission may be because he is sure his readership will already be well-versed in the writings of previous Zaydi authorities, it should be noted that such an assumption was not made by Ibn al-Murtad̄a, who, as been seen above (in Section 5.23), quotes the views of previous Zaydi imāms very frequently indeed.

Al-Shawkānī's Kitāb al-Musāqāh wa-al-Muzāracah in the Nayl a7-Awtär falls broadly into two sections. In the first (pp. 7-11) his concern is to show that in his opinion the sharecropping contracts of both muzāracah and musāqāh are legally valid. In support of this view he quotes several badiths and the opinions of many eminent jurists from the different legal schools. The substance of the badiths he quotes have already been discussed in Chapter 3 (Section 3.3 above). His second and longer section (pp. 11-18) deals with situations in which such contracts can be legally invalid, and here again he underpins his argument with the relevant badiths and cites the views of other jurists. The circumstance with which he is principally concerned where a contract would be invalid is when a landowner stipulates that his share of the harvest is to be cropped from a specific plot of ground and particularly where that plot is close to irrigation channels and is therefore better watered.

\footnotetext{
40 Coulson $1964: 119$.

41 Brockelmann 1937-49, Supplement :II, 818. Al-Shawkānī's intellectual "emanicipation" from sectarian restraints, especially regarding his poetry, is the subject on an article by Mubammad Muștafā Balbajj (1990). See also al-Ahdal (1990) and Rafīdah (1990).
} 
Although much longer than the section devoted to sharecropping by Ibn al-Murtadā, al-Shawkānī's treatment of the subject can be summarised rather more succinctly.

\subsection{A Synopsis of the Kitāb al-Musāqāh wa-a 7-Muzäracah with Comments}

As is common in such figh works as Nayl al-Awtār, al-Shawkānī opens this chapter on sharecropping with the recitation of the bad7ths relevant to the subject. Here, as throughout the work, his sources of badiths are not only the two most highly regarded collections the Sab̄īăn of al-Bukhārī (d. 256/870) and Muslim (d. 261/875) - but also the four other well-known "canonical" collections of Abū Dāwūd (d. 275/889), al-Nasā' $\bar{i}$ (d. 303/915), Ibn Hanbal (d. 241/855) and Ibn Mājih (d. 273/887).

The first two badīths al-Shawkāni quotes originate from cAbdallāh bn cumar, the son of the second caliph, and concern the Prophet's dealings with the Jews of Khaybar. The substance of these bad7ths has already been discussed in Chapter 3 (Section 3.32), and as was seen there the deal that the Prophet granted the Khaybar Jews was that they could continue to work the land in return for handing over half of the dates and grain they harvested. Al-Shawkāni then quotes the introductory remarks to these Khaybar badiths made by al-Bukhārī, Muslim, Abū Dāwūd and al-Nasā' $\bar{i}$, before drawing a conclusion of his own: that the bad7ths indicate that the seed-corn would be provided by those working the land (that is, the Jews) and that the shares of the two parties to the arrangement would be equal.

The next two badîths quoted by al-Shawkāni which originate respectively from cUmar, the second caliph, and cAbdallāh bn cAbbās, a cousin of the Prophet, also concern the deal with the Jews at Khaybar.

Al-Shawkānī's fifth hadj̄th, from Abū Hurayrah, a Companion we11-known for the large number of badiths he narrated, deals with the event at Medina when the Anşār allowed the newly arrived Muhājirūn to work the land in return for a share of the harvest, while the sixth badith is the narration from Tāwus that a certain 
Companion called Mucādh bn Jabal leased land in return for a third or a quarter of the harvest during the Prophet's lifetime and continued to do so throughout the caliphates of the first three Rāshidūn Caliphs Abū Bakr, cUmar and cuthmān, spanning the years $11 / 632$ to $35 / 656$. Al-Shawkāni follows this with a further narration from al-Bukhärī which states that several well-known and eminent

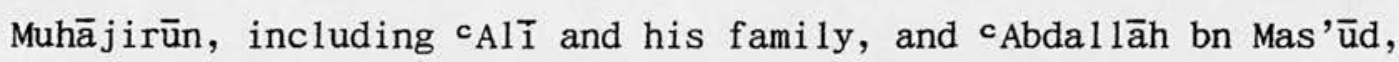
cUmar bn ${ }^{c} A b d$ al-cAzizz and the family of $A b \bar{u}$ Bakr, all made sharecropping contracts in exchange for a half or a quarter of the harvest. Al-Shawkānī then comments on the reliability of the isnads of these badiths. The only error he notes is in the bad7th which concerns Mucādh bn Jabal since the latter had already died during the caliphate of cumar and that Tâwūs could not therefore have heard the narration from Mucādh.

In presenting these wel1-known had̄iths a1-Shawkānī's intention is quite clear. He is establishing, first, that the Prophet himself made a sharecropping contract, and second, that eminent Muslims practised the system with the tacit approval of the Prophet and continued the practice for at least twenty years after his death. These are points which al-Shawkān̄̄ takes up later as evidence that sharecropping contracts are valid.

Al-Shawkāni then briefly discusses the nature of the musāqāh contract. According to him, the majority view is that it is a sharecropping contract on land growing date-palms, grape-vines, and any other trees which bear fruit, though others have restricted its application. He says:

The musāqāh is [a contract] in date-palms, grape-vines and all fruiting trees in which a known part of the fruit goes to the aj $\overline{7} r$ (tenant); this opinion is held by. everyone. In his later writings $\mathbf{4 2}$ al-Shäf $i^{c} \bar{i}$ applied [the term] only to date-palms and grape-vines. Dāwüd43 restricted it to date-palms. Mālik said [the contract] is valid in sown crops and trees but is invalid in vegetables according to most authorities, but it has been narrated from Ibn Dīnār

42 The Arabic reads here: wa-f7 qawli-hi al-jadid. Cf.

al-Nawawī's use of al-qadīm (in Nayl a 1-Awtār :II, 1432-3) to refer to al-Shäficī's earlier writings (Chapter 4, Section 4.32). 
that he [Mālik] considered it valid [even] in [vegetables].44

Al-Shawkāni now embarks on a short discussion of the etymology of the terms muzāracah and mukhäbarah. Muzāracah is easily disposed of since the root at least is clear $(z-r-c$, sowing). Mukhäbarah is more of a problem since, he says, different authorities have different views of its provenance. He himself, it would appear, prefers the derivation of the term from khabīr, meaning farmer, but he quotes three other possibilities favoured by other authorities: khabär (soft land), khubr (a portion or share), and Khaybar.

Al-Shawkānī's next concern is to give the Shäficī view of the practice, and in so doing he quotes directly from the Kitāb a l-Umm. Al-Shawkānī's words read as follows:

The Shäficis have explained mukhäbarah by saying that it is working on the land in return for part of what is produced from it, the seed-corn being supplied by the labourer. Some people have held that the terms musāqāh, muzäracah and mukhäbarah all have the same meaning. Al-Shāf $i^{c} \bar{i}$ himself stated this. In the [Kitāb] al-Umm under the chapter on the muzaracah he says:

"If a man hands over [a plot of] ard bayda', (land on which there are no perennial crops) to another man on the basis that the latter cultivates it and one part of anything which is produced from [the land] belongs to him, then this is the mubäqalah, mukhäbarah and muzäracah which the Messenger of God (may peace be upon him and his family) prohibited."

Al-Bukhāri made a similar statement, he being of the [same] viewpoint as the Shäficis. ${ }^{45}$

43 The Dāwūd meant here is probably Dāwūd bn Khalaf (d. 884), the imām of the (now extinct) Zähirī School which was characterised by its literal approach to interpreting the Qur'an and the bad7ths, since al-Shawkāni later quotes a view of that madhhab $\left(: 9_{13}\right.$ in the cited published edition).

44 Al-Shawkānī Nayl a 7-Awtār :V, 815-19.

45 Al-Shawkānī Nay7 a7-Awtār :V, 826-96. Al-Shawkānī's quotation from al-Shäficī is to be found in the Kitāb al-Umm :VII, 101. 
Al-Shawkānī follows this with a quotation from al-Fīrūzābādī's a)-Qämus al-Mub̄it which defines the muzäracah in substantially the same terms as the definition by al-Shāfic $\bar{i}$, though al-Fīrūzābādî's definition of mukhäbarah makes by no means any clear distinction. Al-Shawkānì's words in translation are:

[Al-Fīrūzābādī, the author of] the Qämus, says:

"The muzäracah is the mutual deal on land for part of what is produced from it, the seed-corn being supplied by the landowner", and:

"The mukhäbarah is when he sows on the basis of half or a similar proportion". 46

Al-Shawkāni now considers the question of time limits to sharecropping contracts, and specifically whether or not the agreement made between the Prophet and the Jews of Khaybar had a fixed time period. He notes that some (unnamed) authorities hold the view that there should be a time limit, quoting in support of this view a bad7th about the Prophet's order for the Jews' final expulsion from Arabia. He also mentions the opposing view, however, and it is not clear from the text which opinion he himself adheres to on this matter.

He then gives the details of the authorities from whom the badîth about the deal struck between the Anşār and the Muhājirūn in Medina originated.

On the way he observes that there exist other bad7ths which mention sharecropping contracts but that al-Bukhär $\bar{i}$ includes them not in his chapter on sharecropping but rather under salaf, a type of transaction involving advance payment for goods which will be delivered at a later date. Al-Shawkānī deduces that al-Bukhārī did this to show that there is no difference of opinion among the authorities about the legality of sharecropping. The point is that these other badjiths which al-Bukhärī categorises as dealing with salaf would seem ostensibly to prohibit sharecropping contracts

46 Al-Shawkāni Nayl al-Awtār :V, 96-7. The quotations he makes

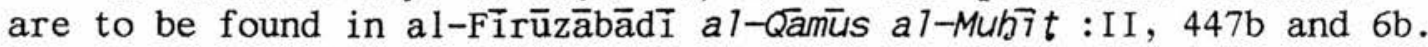


outright. Al-Shawkān $\bar{i}$ does not mention this here though he takes up later the question of conflicting evidence from the hadiths ${ }^{47}$.

Al-Shawkāni then summarises the validity of muzäracah and musāqāh contracts according to the authorities who support the view that these contracts are legal, including several Companions of the Prophet and jurists including the Hanafîs Abū Yūsuf (d. 182/798) and Mubammad bn al-Hasan al-Shaybānī (d. 189/804). Al-Shawkānī's summary is, in essence, that both contracts are valid whether as free-standing contracts the one involving sown crops and the other irrigation of perennial crops, or as a combined contract involving both types of crop. Although al-Shawkānī does not mention the fact, the significance of this can be understood when it is remembered that the developed Shäfici doctrine allows muzāracah only if it is an integral part of a musāqāh contract, as was discussed in Chapter 4 (Section 4.3 above) when al-Nawaw's 's view was being considered. That is to say, al-Shawkānī is arguing here that the Shāfici $\bar{i}$ restriction on sharecropping with annually sown crops is not required.

It is at this point that al-Shawkān $\overline{1}$ introduces what is to become the main thrust of his argument against authorities who deny the validity of sharecropping. His thesis is that they have misinterpreted the nature of the prohibitions contained in the so-called prohibition badiths in either of two ways. First, these prohibitions in al-Shawkānī's view are of the nahy a 1-tanzīh category rather than nahy al-tabrim: that is to say, injunctions to avoid if possible certain actions, and not outright prohibitions. Second, the bad7ths which prohibit sharecropping apply only to cases where the shares of the crop for each of the parties come from different plots of land. A translation of al-Shawkānī's words is as follows.

47 In an earlier chapter of Nayl al-Awtär (:V, $278 \mathrm{ff}$.) al-Shawkāni himself discusses the salaf hadiths recorded by al-Bukhäri and the other traditionists. 
Concerning the badiths that prohibit the muzäracah [the authorities who uphold the legality of sharecropping] respond by saying that they relate to a $\tan z \overline{7} h$ prohibition. Some say that they relate to cases where the landlord stipulates [that his share of the crop is to come from] a specific plot [of the land].

Before discussing this further al-Shawkānī establishes that even those authorities who deny the legality of sharecropping as such accept that leasing land for a rent on which a cash value can be placed is permitted. He goes on to say that sharecropping however is different from ordinary leasing in that the cash value of the rent cannot be known at the time the contract is made, and that in the view of the authorities who reject sharecropping the Khaybar bad7 ths cannot be used as evidence to support the practice since the Jews at Khaybar were conquered canwatan (that is to say, by force $)^{49}$. They therefore became slaves, so the argument goes, and could not act as equal partners in a sharecropping contract.

Al-Shawkānī's discussion of this and allied matters leads into the second section of the chapter. In it he is principally concerned with situations in which sharecropping contracts are indeed invalid and how the opponents of sharecropping have wrongly generalised such circumstances to sharecropping per se. He begins by quoting five bad 7 ths at least three of which originate from the Companion Rāfic bn Khadīj. The gist of all these five badjiths has already been discussed in Chapter 3 (Section 3.33 above). It is that during the Prophet's lifetime Muslims used to practise sharecropping in which the shares of the two parties would come from different parts of the land and that the Prophet prohibited this practice. In three of these badiths the plot which produced the landowner's share is stated specifically to be the part of the land

\footnotetext{
48 Al-Shawkānī Nayl al-Awtār :V, 10s-6.

$49{ }^{c}$ Anwatan, by force, as opposed to sulban, by treaty. In theory, the way in which lands were conquered by the Muslim decided the manner by which they were to be dealt with from the points of view of ownership, taxation and so on, though as F. Løkkegaard, D.C. Dennett and others have shown the theory did not always apply in practice (Løkkegaard $1950: 45 \mathrm{ff}$. et passim; Dennett 1950 passim).
} 
alongside water-channels (which could be expected to be better irrigated). In the other two the narrator states that different plots would often produce differential yields (and would therefore also be unfair to one or other of the parties to the contract).

So that these five bad7 ths may be fully understood by his readers al-Shawkāni then embarks on a detailed explanation of the key phrases in them. First, he explains the term baql, which occurs in one of the badîths, by quoting from al-Fīrūzābādī's al-Qämus a7-Mubit. Al-Fīrūzābādì gives four meanings, one of which is muzāracah and the other three are transactions involving gharar (risk).

Al-Shawkāni then argues that what the Prophet had prohibited here is not sharecropping itself but a form of sharecropping in which the shares of the parties come from different plots of land, a practice which leads to gharar. Gharar must of course be strenuously avoided since, as al-Shawkānī later states, it "leads to disputes and to a futile waste of people's resources"50.

The next point which al-Shawkān $\bar{i}$ sets out to explain is subsidiary to the main thrust of his argument. It concerns whether the narrator Rāfic bn Khadīj (whose sharecropping badîths were examined in Chapter 3 , Section 3.33 above) had correctly reported in this context that leasing land for cash was permitted or whether he had interpolated this from another frame of reference. The question of leasing land for cash is a subject that al-Shawkān $\bar{i}$ returns to later.

Among the significant phrases in the badj ths which al-Shawkān $\bar{i}$ quotes are three terms meaning the banks of water-channels (al-mādhiyānāt, aqbāl al-jadāwil and al-arbicā'). After clarifying these he restates at greater length his argument againșt those who claim the badiths prohibit sharecropping: what has been prohibited,

50 Al-Shawkānī Nayl al-Awtär :V, 1225-26. The Arabic here reads:

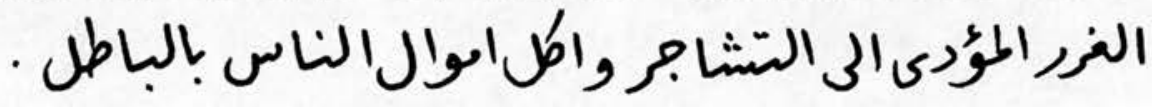

a1-gharar a1-mu'add̄̄ i Ta al-tashājur wa-akl amwāl al-nās bi-al-bätil. 
he says, is not sharecropping itself but rather sharecropping contracts which include stipulations that the crop is to be divided according to where it grows on the land or to other conditions which can lead to gharar. To support his argument further he notes again the fact that both the Prophet and the Companions practised such dealings and he quotes from another bad7th related by Rāfic bn Khadi $j$ which relays the words of the Prophet:

"Whoever has land, let him cultivate it himself or let him get someone else to cultivate it for him, and the two parties should not find it reprehensible to practise this arrangement in return for a third or a quarter of the crop nor for stated foodstuffs."s1

Turning now to narrations which relate that the Prophet seemingly prohibited sharecropping al-Shawkāni quotes two badi ths from the collection of the Traditionist Abū Dāwūd, one of which contains the Prophet's rebuke to a sharecropper: "Arbaytum" (You have practised ribā (unjustified profit)). But al-Shawkān̄ argues that such bad7 ths cannot invalidate the many authoritative bad7 ths which indicate that the Prophet did institute sharecropping at Khaybar, that the Companions continued the practice after his death, and that therefore the practice per se cannot be ribā. Nor can the badiths which permit sharecropping be taken as specifically valid only for the Prophet and not valid for any of his followers since his most eminent Companions continued to practice it. If it had been forbidden, al-Shawkānī says, it would be extremely unlikely that the Companions would be unaware of the fact.

Al-Shawkānī then moves on to quote three further badjiths, this time from the Companion Asīd bn Zuhayr but again involving Rāfic bn Khadij. The sharecropping system in question here involved not only a share for the landlord from the part of the land irrigated by water-channels as in the previous badiths, but also in addition the qusarah (the grain which is not expelled from the husk after the first threshing). After stating this, Asīd is then told by Rāfic

51 Had̄̄th quoted by al-Shawkānī Nayl al-Awtār :V, 1313-14. 
that this practice was forbidden by the Prophet. A1-Shawkānī notes that this full version of the badith is found in the collections of Ibn Hanbal and Ibn Mājih, but also that two other collections those of $A b \bar{u}$ Dāwūd and al-Nasā' $\bar{i}$ - significantly omit the beginning of the narration in which Asīd describes the kind of sharecropping involved. After a brief aside in which al-Shawkāni explains the meaning of qusărah and that baq 7 here means land fit to be cultivated, he cites a further badīth, again from Rāfic, in which the share of the landlord is a quarter of the harvest and in addition some absolute measures of fruit and barley, and the Prophet forbade this.

As al-Shawkāni perceptively observes, the first part of Asid's words are crucial to understanding the true nature of the prohibition. That is to say, sharecropping is not itself forbidden, but rather sharecropping which involves extra stipulations which favour unequally one of the parties, and especially the landlord. In any case, according to al-Shawkānī, the prohibition is a $\tan \overline{\mathbf{i}} \mathbf{h}$ prohibition, not an absolute prohibition binding in all circumstances.

This is followed by two further bad7hths and al-Shawkānī's comments on them. Both relate substantially the same kind of situations as that narrated by Asīd bn Zuhayr. The first of these originates from Jābir and the second from $\mathrm{Sa}^{c} \mathrm{~d}$ bn $\mathrm{Ab} \bar{i}$ Waqqās. Al-Shawkāni concludes as before that the Prophet's prohibition as narrated in the badith must refer to the extra stipulations by which the landlord profited unduly, either by having his share of the harvest come from a favoured part of the land, or else by having extra produce added to his share, or by both.

The remainder of what al-Shawkāni has to say in this chapter is largely a reiteration of this argument. He quotes several more bad7ths in support of his interpretation, analysing after each narration the critical phrases and drawing parallels with the bad7ths he has already quoted. A subsidiary argument, emerging from certain of the badiths, concerns the permissibility or otherwise of allowing land to lie fallow if neither the owner nor a tenant can cultivate it. Al-Shawkānī points out that certain (unnamed) 
authorities disapprove of leaving land uncultivated because to waste assests is prohibited and merit is attached to sowing and planting, though he himself finds this reasoning unconvincing. As he rightly indicates, land even if it is not under cultivation can be beneficially used to produce timber and as pasturage for livestock, and leaving it fallow, he adds, might well improve its fertility so that one lost harvest would be made up for in subsequent years.

Al-Shawkānī then comes to his conclusion. If a landowner wishes he may cultivate his land himself or lend it gratis to someone else to cultivate for him or leave it fallow, though he is compelled to do none of these. He then adds a fourth option which is allowed by the consensus of jurists, namely, to lease the land, and the implication is that the lease can be of the sharecropping type.

\section{33 Discussion}

Although he touches on other aspects of sharecropping along the way, such as the etymology of the terms muzāracah and mukhäbarah, and the explanation of certain uncommon terms in the bad7ths meaning waterchannels, it is clear that the dominant concern of al-Shawkānī in the Kitāb al-Musāqāh wa-a7-Muzāracah of his Nayl al-Awtär is to prove the legitimacy of sharecropping contracts in Islam. There are two thrusts to his argument and both are founded on a detailed examination of the relevant badiths.

His first thrust relies on the fact that there are many authoritative bad7ths which relate that not only the Prophet himself but also a number of the Companions and the Successors engaged in sharecropping. His second thrust is that the bad7ths which ostensibly prohibit sharecropping can be shown in fact.not to prohibit it absolutely. Either they forbid it only in certain cases, notably where supplementary conditions are attached to a contract which benefit one party unfairly, such as the stipulation that the landowner's share should come from the land alongside the water-channels, or else they are of the nature of $\operatorname{tanz} \overline{7} h$ injunctions (that is, injunctions to avoid certain actions if it is possible to do so) and not absolute prohibitions of the nahy al-tabrīm kind. 
The lines of his argument then are clear enough. What is perhaps not so clear is why al-Shawkāni should have devoted his evidently considerable intellect to showing at such length and in such detail why all three forms of sharecropping should be considered valid. During al-Shawkānī's lifetime sharecropping in the Yemen is likely to have been as commonplace and as acceptable a means of leasing land as it will be shown to be, in Chapter 6 below, in the present-day Yemen, and as it no doubt was at the time of Ibn a1-Murtadā. Yet neither the authors of the modern Yemeni Civil Code a1-Qanūn a 1-Madan̄̄ nor Ibn al-Murtad̄a make any more than a passing reference to the bad7ths by which sharecropping in its three main forms can be justified before they move on to the detailed practical regulations. For al-Shawkānī, on the other hand, to justify sharecropping was his central purpose.

\subsection{Concluding Remarks on the Zaydi Position}

Like his Zaydī predecessor Ibn al-Murtad̄a, al-Shawkānī accepts all three main forms of sharecropping as legally valid in principle, given certain basic qualifications. This marks both authorities off from the Shäficīs who, as has been seen, accept only musāqāh and a very limited form of muzäracah. Indeed, the Zaydi stance would seem very much more relaxed, and could perhaps be called more pragmatic, about sharecropping than many Sunn $\vec{i}$ authorities. This was true too of the sharecropping Articles of the Yemeni Civil Code al-Qanūn a)-Madan̄ which was discussed in Chapter 3 (Section 3.5 above) and which might therefore be seen as encapsulating the Zaydi view rather more than the Shäficī view. How far the Zaydī School can be viewed, as N.J. Coulson has asserted, as "a fusion of Sunnite and Shīcite principles" cannot of course be decided on the short and specific passages under study in this chapter. However, it is surely notable that both Ibn al-Murtad̄a and al-Shawkānī do indeed draw extensively on the views of the four Sunni schools of law, including the Shāficis, even though not always agreeing with them.

To that extent therefore Ibn al-Murtad̄a and al-Shawkānī are similar, despite the four hundred years that separates them. However, al-Shawkānī's approach to the subject is very different 
from that of Ibn al-Murtadā, as has been mentioned at the end of the previous section ( 5.33 above), and the reason is that their intentions are different. In fact, in the passages of these two authorities which have been examined in this chapter we are dealing with different kinds of fiqh text. Ibn al-Murtadā is concerned with putting forward in a detailed though abbreviated form to the Zaydi 'ulamā' of his day the practical regulations affecting the different types of sharecropping, such as what the duties of the tenant are, or what happens if the landowner dies during the term of the contract, and he spends hardly any time arguing the legal theory of the validity of the practice. For him, its validity is axiomatic and the briefest of mentions of supporting badiths is all that is required. With al-Shawkāni the position is reversed. He presents detailed arguments for and against different kinds of sharecropping contract, all founded on a close examination of the badiths, but he does not concern himself with the day-to-day regulations of how sharecropping contracts should be arranged and governed in practice. Further, given this, it is by no means surprising that al-Shawkānī makes no mention of custom (neither curf nor cādah) at any point, whereas Ibn al-Murtada specifically appeals to custom when he is discussing the conditions of labour and the duties of the tenant. In a sense therefore Ibn al-Murtada's work, despite its linguistic and stylistic difficulties, is much more of a practical guide or handbook to sharecropping than that of al-Shawkānī. It is to sharecropping as it is practically organised in the Yemen today that the focus of this thesis now turns in Chapters 6, 7 and 8 , which constitute Part II. 
PART II

YEMENI SHARECROPPING IN PRACTICE 
CHAPTER 6 : THE CURRENT YEMENI SITUATION AND ARRANGEMENTS

6.1 Introductory Remarks

6.2 The Field Data

6.21 Methodology

6.22 Coverage

6.3 The Yemeni Terminology of Sharecropping and Related Matters

6.31 Landholdings in General

6.32 Sharecropping Land

6.4 The Dominance of Sharecropping in the Yemen

6.41 Owner-Occupied Land versus Tenanted Land

6.42 The 1987 UN Report on Land Tenancy in the Northern Yemen

6.43 Sharecropping versus Fixed Rent Tenancies, according to the Present Survey

6.44 Fixed Rent Tenancies

6.5 Sharing Systems

6.51 General Considerations

6.52 Crop-sharing Systems by Source of Water

(a) Land Irrigated by ghay 7 and say 7

(b) Rain-fed Land

(c) Land Irrigated by Wells

6.53 Crop-sharing Systems by Region

6.54 Crop-sharing Systems by Types of Crop

6.55 Crop-sharing Systems by Landowner

6.6 Concluding Remarks on the Current Yemeni Situation 


\subsection{Introductory Re-arks}

The theoretical issues involved in sharecropping in Islam have been examined in Part I of this thesis. This chapter, Chapter 6, together with much of the rest of Part II, is concerned with sharecropping in the Yemen as it appears in practice. The source of the information on which this chapter is based is mainly the fieldwork which the present writer conducted in the Yemen in 1992 and 1993 and which will be referred to here as the present field survey or the present field information. It is supported by and contrasted with information derived from the published material of other field researchers where such is available and comparable.

The chapter begins, in Section 6.2, with an explanatory overview of the methodology and coverage of the present field survey. In Section 6.3 there follows a discussion of the land tenancy and sharecropping terminology as it is currently used in the northern part of the country. Appendix 1 includes all the known terms. Section 6.4 then shows the dominance of sharecropping in land tenancy in the northern Yemen and Section 6.5 analyses the many different systems of crop-sharing found there.

\subsection{The Field Data}

\subsection{Methodology}

Field information was collected in the northern part of the Yemen during two periods of field study totalling almost four months in 1992 and 1993. The aim of the first field visit of five weeks in September and October 1992 was primarily to gain an acquaintanceship with the northern Yemen at first hand and in particular its agricultural geographyl. Journeys were made to several regions including the high plateaux around Sanc $\bar{a}$, the mountains to the west of Sancā', the Zabīd area on the coastal plain of Tihāmah and the mountains around Ibb. In each region an overview of agricultural 
practices and particularly land tenancy and sharecropping systems was gained from conversations with landowners, tenants, qā $\overline{7} \bar{s}$, officials of the Ministry of Agriculture and others with specialist knowledge. The field information so gained provided the basis for a longer and more intensive field visit a year later during which a more systematic survey could be conducted.

This second field visit of over two months was undertaken during August, September and October 1993. A list of topics, based on questions that had arisen during the first field trip and from the study of certain Arabic texts 2 and secondary literature was drawn up as the basis for a more systematic survey of farming practices, especially crop sharing, and the part played in them by curf (customary law).

In each location visited information was sought from local farmers and other knowledgeable sources on the following topics:

- Background information on the location, the landholdings, and the marketing or disposal of the produce;

- Information on the crops, and the ownership of trees and other perennials;

- The source of the agricultural water (rain, we11, ghay7, $\operatorname{say}^{3}$ ), and the ownership of the water rights and, where present, the water pump;

- Whether the land is owner-farmed, farmed by a tenant paying a fixed rent, or sharecropped;

- If tenanted for a fixed rent or sharecropped,

- the details of the contract, including the local terminology involved;

- whether the contract is written or verbal;

1 The author is grateful for the grant of $\$ 250$ from the Carnegie Institute towards the costs of this first field visit.

2 In particular, the passages on sharecropping in Ibn al-Murtadā's a7-Babr a7-Zakhkhär discussed above in Chapter 5 (Section 5.2) and the sharecropping fatwas of $\mathrm{Ibn} \mathrm{Ja}^{c}$ mān which will be discussed in Chapter 8 (Section 8.5).

3 The terms ghayl and sayl were introduced in Chapter 1 (Section 1.3) and will be further examined later in this present chapter. 
- which party is responsible for supplying the seed and other agricultural inputs;

- the amount paid in rent, either as a fixed sum or a proportion of the crop, and if a proportion, how much is due to the landowner, the sharecropper, the water pump owner (if present), and whether these proportions are paid in cash or in kind;

- the length of contract, and whether there is any special renewal procedure;

- whether by custom any services or special gifts are expected of the tenant which are not specified in the contract;

- Details of sharecropping contracts which involve animals, including the local terminology involved, and details of any customary presents generally to the owner of the animals;

- The main causes of disputes between landowners and their tenants and neighbours, and the methods of settlement of such disputes.

Sixty-six interviews were conducted with approximately 100 tenants, landowners and others involved in agricultural matters, sometimes in groups of two, three or four, but more of ten individually. Sixty of these interviews were recorded on audio cassettes, covering about 13 hours of recording time. The other six were taken down in note form only, in most cases because conditions were not suitable for audio recording (of ten because a water pump was working close by). In addition, conversations of a more casual kind were engaged in with market traders, motor pickup owners and other Yemenis about agricultural matters whenever the opportunity arose.

The interviews, though loosely structured, were of a free-flowing nature as far as possible, and although most respondents were asked most questions, there was no meticulously applied format 4 . Where a line of questioning seemed to be producing no useful information, or no additional information, it was

4 It should be mentioned that the 66 interviews did not form a formal questionnaire survey. It was considered that such an approach would have been inappropriate, given both the nature of the material being enquired into and also the lack of a team of skilled interviewers. 
abandoned. On the other hand, where a question provoked an unexpected or interesting response, the subject was pursued and of ten produced a new line of questioning which was followed in later conversations.

Objections to the recording of the interviews on the grounds that respondents would be inhibited from speaking the truth are judged to be unfounded. In the first place, no information of a particularly sensitive economic, political or personal kind was being demanded, and names of respondents were deliberately not asked for (though in fact many respondents volunteered theirs). In any case, most Yemenis have already become accustomed to hearing Yemeni farmers and others being interviewed on radio and of ten on. television too. In the event, practically all the respondents talked willingly.

Recording the interviews also had positive advantages. It allowed the extraction of much more information from the responses than manual note-making would have permitted, and moreover a greater certainty than would otherwise might have been possible about the exact meaning of what respondents said, particularly in cases where unfamiliar terminology and dialectal usages were involved, since doubtful passages in the recordings could later be studied at leisure and if necessary played back in the presence of other respondents from the same area. This was particularly valuable in the case of older farmers whose diction was not always fully comprehensible to the present writer on first listening but among whom were found some of the most informative respondents concerning traditional practices.

\subsection{Coverage}

Table 6.1 shows the regions into which the locations at which the interviews were conducted have been classified. The criteria on which the classification is based are climate, topography and dominant sources of water. Figure 6.1 maps the locations of the interviews in relation to these regions.

As can be seen from the table and figure, all the study regions are represented by at least five settlements each and at least 13 
Region: Northern Nountains:

No.of interviews:

Characteristics: cool climate on upper slopes, warm in valleys; ghay 7 irrigation and rain-fed agriculture, with wells in piedmont areas

- al-Tawīlah

- al-Ahjur

- Qābil Wādī Zahr

- Shibām

- Sanāc (SW of $\operatorname{San}^{c} \bar{a}$ ')

- Madinat al-Shirq

1

3

2

1

2

Regional total:

Region: Northern Plateaux:

Characteristics: cool climate; rain-fed agriculture and pump wells

- cAmrān

- Najr

- al-Hāwir $\bar{i}$

- Hamdān

$\begin{array}{ll} & 2 \\ & 3 \\ & 1 \\ & 1 \\ \text { Regional total: } & 7\end{array}$

Region: Central Plateaux:

Characteristics: cool climate; rain-fed agriculture and pump wells

- Dhamār

- Afq

- al-Mayfacah

- Ribāt c Imrān

- al-Kahaylah (south of Radāc)

Regional total:

2

1

7

.




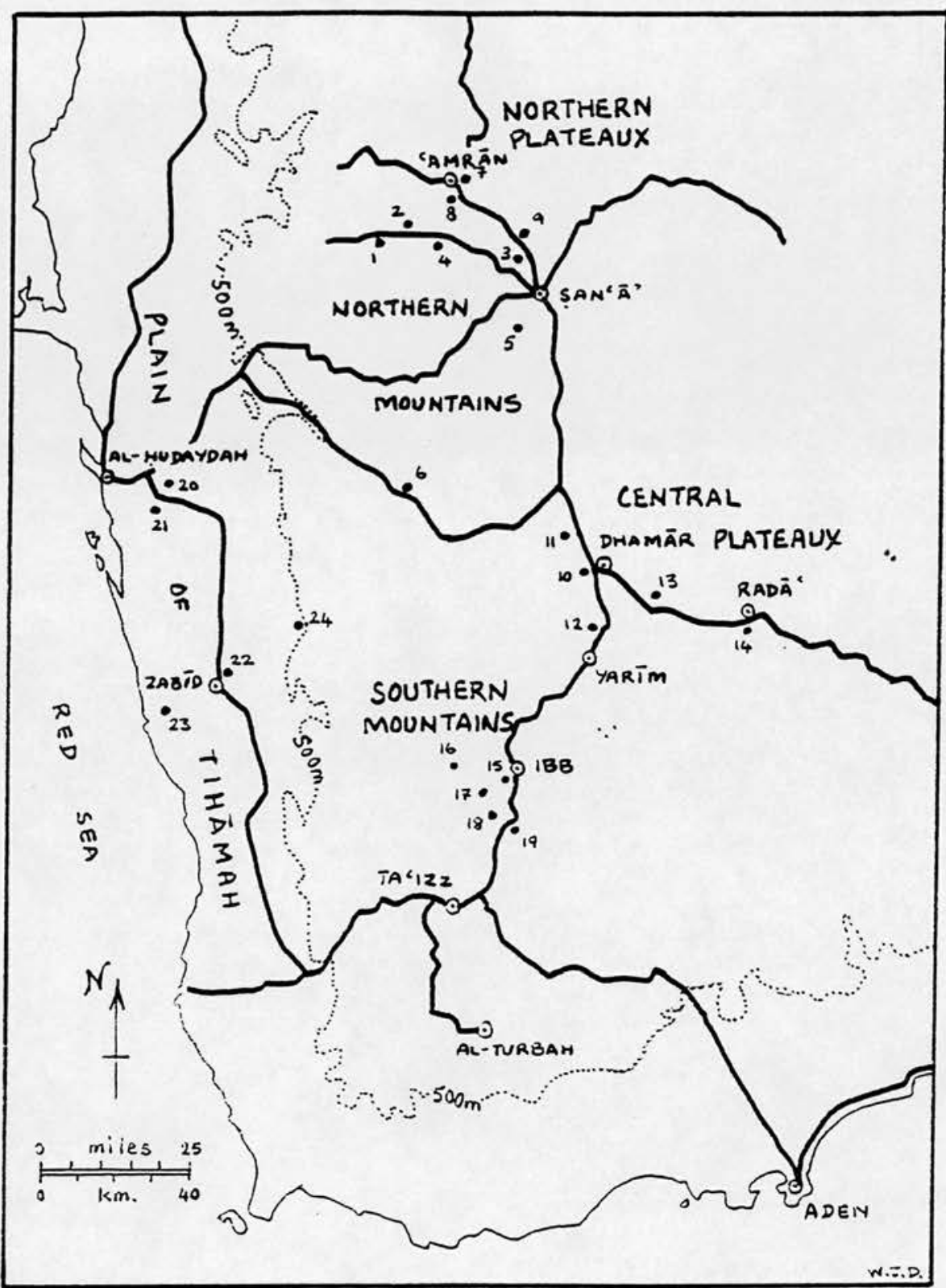

$\sim$ tarred roads

- sample locations

$\odot$ other settlements

Key to Sample Locations:

1 al-Tawillah

2 al-Ahjur

3 Qābil Wādī Zahr

4 Shibām

5 Sanāc

6 Madinnat al-Shirq

7 cAmrān

$8 \mathrm{Najr}$
9 al-Hāwirī \& Hamdān

10 Dhamār

11 Afq

12 Ribāt cImrān

13 al-Mayfacah

14 al-Kahaylah

$15 \mathrm{Ibb}$

16 al-cudayn
17 al-Waqash

18 Dhī al-Sufāl

19 al-Q $\bar{a} \mathrm{c}$ idah

20 al-Kimbāh̨iyah

21 al-Mukaymanīyah

22 Zabid

23 al-Suwayq

24 Mishrāfah 
interviews, except the Northern Plateaux in which the available time permitted only seven interviews to be conducted. Further, in the Central Tihāmah region only one settlement (Mishrāfah) was visited in the Tihāmah piedmont zone. This was unfortunate, and particularly so since this zone is an extremely important area of sayl (spate) irrigation and sayl as a water source is not we 11 represented in the field survey data as a whole. But because of both the hostile summer climate and the difficulties of transport away from the few tarred roads in the region, more time could not be devoted to extending the study to other settlements in the Tihämah piedmont. It is considered however that the main part of the Central Tihämah and also the other three regions are reasonably well represented by the sample settlements and interviews.

Nevertheless, the number of farmers covered in the interviews is of course a negligible proportion of the total population involved in agriculture, and given the large differences in conditions both between and within regions, and therefore the number of subsamples necessary for full analysis, this sample cannot be considered a reliably representative sample in terms of strict statistical analysis. The representation of lands irrigated by say 7 in particular, as already noted above, was less than desirable.

The aim of the field survey was not however to collect data of an essentially statistical kind, such as the economic conditions of the farmers or the relative productivity of different crops, and it does not claim to be representative statistically of even the northern part of the Yemen. In view of the practical and logistic difficulties of field surveys in areas such as the Yemen (including particularly transport and accommodation in rural areas), representative coverage of the whole country and the use of statistically sound sampling methods are hardly a practical possibility for individual researcherss. In the present survey a particular settlement was of ten chosen to be visited not for any sound scientific reason but simply because a pickup vehicle was chanced upon that happened to be going there and had a space vacant among the sacks of grain and the couple of goats, and returning to 
base from remote settlements so selected sometimes proved to be difficult and time consuming.

Even so, an effort was made to collect information of a qualitative nature over as wide an area and in as many settlements of the northern part of the country as was practically feasible, so that as much detail as possible could be examined of the variability of terminology, procedures and practices in the field of Yemeni agricultural tenancies and in particular sharecropping. In each settlement visited as many farmers as possible were engaged in conversation, though it was found in fact that replies to the same questions in the same settlement very soon began to produce repetitive answers after a few knowledgeable respondents had been interviewed. In addition visits were paid in each area to local officials, such as $\overline{q a} \bar{d} \bar{s}$ and village registrars, and to the regional and local representatives of the Ministry of Agriculture, and these were also interviewed; such respondents constitute seven of the total of 66 interviews. It is on the information derived from the 66 interviews that the rest of this chapter is largely based.

\subsection{The Yemeni Terninology of Sharecropping and Related Matters}

\subsection{Landholdings in General}

A common term among Yemeni farmers for landholdings in a general sense is iqtāciyat (rather than iqtâa $\bar{a} t$ ) and landowners are sometimes referred to especially by tenants as iqtāc $\overline{7} y \overline{7} n^{6}$. More of ten a landowner is called, as in the literary works, mālik al-ard, or simply mālik, or sometimes rabb al-ard. Sabib al-ard is also frequently heard, possibly most frequently on the plain of Tihämah.

5 Even international organisations and consultancies backed by far greater means than individual researchers have reported similar problems, as, for example, in the socio-economic survey associated with the building of the road from $\mathrm{Ta}^{\mathrm{c}} \mathrm{izz}$ to al-Turbah funded by the World Bank (Mitchel1 $1978: 17$ ). Similarly, the UN report on Yemeni sharecropping, which will be referred to in more detail later in the text, listed a number of problems which the field survey team encountered, some of which were of a practical or logistic nature and included transport difficulties (UN $1987: 4$ ). 
When a distinction has to be made in local terminology between land owned by private individuals and land held by a waqf or by the government, private land is often called hurr ("free" land), as opposed to ard mawqūfah or arāọj al-awqāf (waqf land) and sawāf $\overline{7}$ or the singular sāfiyah (government land).

The features of the different irrigation systems of ghayl ( $\mathrm{pl}$. ghuy $\overline{7} 7$ ) and say7 (p1. suyū 7 ) have already been outlined above in Chapter 1 (Section 1.3). Generally speaking, ghayl irrigation is from permanently flowing underground springs, whereas sayl irrigation depends on occasional spate flow of wädjs. There are however some instances where these terms are either replaced by or used instead of other terms, and to an outsider this can be confusing. On the plain of Tihāmah (and possibly elsewhere) land watered by sayl is called simply wäd $\overline{7}$, wäd $\overline{7}$ in this context meaning the land watered by the spate flow of a wadj. At al-cudayn in the Southern Mountains west of Ibb (and possibly elsewhere) sayl can mean a permanent or quasi-permanent water flow, rather than an occasional spate flow, and so would be closer to the meaning of ghay7. On the high Central Plateaux in areas where there are no true ghayls, the term ghayl is of ten used to mean the water channelled from wells.

Land relying solely on rainfall is termed caqar (for caqr, barrenness) in at least all the mountain and plateau locations which were visited $\mathbf{7}^{\text {. }}$

A final point to note here is that the plural of $b \overline{7} r$ (for $b i$ 'r, we11) is frequently heard as abyar rather than the classical and more usual $\bar{a} b \bar{a} r .8$

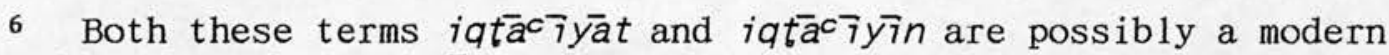
reflection of the iqtác system of land apportionment under cumar and his successor caliphs in the early centuries of the Islamic empire (Løkkegaard $1950: 14-20$ ), though to what extent historical continuity could be proved in the case of the Yemen lies beyond the present discussion. See also al-Sharjabī (1990:92).

7 The effect on rain-fed land of the drought which spanned most of the 1980s was sometimes referred to as al-tacaqqur and the land was said to have dried up ( tacaqqarat al-ard, the land became barren). 


\subsection{Sharecropping Land}

The terms designating a sharecropping contract found in literary sources which were discussed in Chapter 2 (Section 2.3) (primarily muzāracah, mughārasah and musāqāh) were discovered during the field surveys specifically not to exist in the modern, colloquial terminology of any of the areas visited. The corresponding terms for the tenant, such as mughäris or musāa $\overline{7}$, were similarly never encountered in the field. Instead, the sharecropping contract and the sharecropping system were spoken of most usually as sharäkah, sometimes shirk, and of ten as simply ijarah (leasing, renting). The sharecropping tenant is correspondingly either a sharik or else an ajir or a musta'jir. The landowner, as already mentioned above, is usually mälik al-ard, or simply mälik, or else rabb al-ard or sābib al-ard. Sometimes when he is being contrasted with aj $7 \mathrm{r}$ or musta'jir (lit., lessee), he is called the mu'ajjir (lit., lessor), while mälik of ten becomes maTik when coupled with the term sharik (a)-maT7k wa-al-shari $k$, the landowner and the sharecropper). The term $t a b \overline{7} n$, recorded for the owner in Hadramawt by R.B. Serjeant in the context of date-palm cultivation and said to be found on preIslamic inscriptions ${ }^{9}$, was not heard as a term for landowner even in the areas of Tihāmah where date palms are important.

The widespread use in the Yemen at the present day of terms from both the root ' $-j-r$ and the root $s h-r-k$ in the context of sharecropping is interesting. As was pointed out in Chapter 2 (Section 2.3), most of the Schools of Islamic law regard sharecropping as a special form of ijärah (even though such a view can lead to the problem of gharar ( $r i s k$ ) since the rent cannot be specified in absolute terms at the time the contract is made), though there is also the alternative view that the contract is rather a type of sharikah, a partnership on the analogy of the

8 Extensive collections of other Yemeni agricultural terms, and especially those connected with irrigation, are to be found Rossi 1953, Maktari 1971a, and Varisco 1982 :404-60.

9 Serjeant $1955: 11 ; 1981 \mathrm{a}: 308$; and $1988: 149-150$. 
mudarabah commercial partnership. The distinction between the two roots is not however reflected in practical usage today. In the field it was noted that the terms sharik and musta'jir, for example, are used interchangeably to mean sharecropper both by the farmers themselves and by $\overline{q a} \bar{q} \bar{s}$, agricultural extension officers and others knowledgeable about farming. It would seem therefore that insofar as the matter is consciously considered by present-day Yemenis (which may well be not very much) the dual attitude to sharecropping of the Islamic Schools of law is reflected in the modern terminology.

At one settlement in the present survey the terms sharākah and sharik were found not to be used for sharecropping and sharecropper. The settlement was Mishrāfah, located just upstream of the point where the Wădi Rimac debouches onto the plain of Tihāmah and where the crop (on the wad flood plain) is predominantly bananas. Here the term for what is essentially a sharecropping system is sharäbah (or perhaps shirähah) and the sharecropper is a sharīh or shärib (pl. shurrāh). These terms were not heard in any other area visited and they may be restricted to the Tihämah piedmont area or else to areas where bananas are the chief produce. Unfortunately, Mishrāfah was the only settlement visited where the terms were found and moreover the only place where bananas were the dominant crop, and the terms may well be more widely used in northern Yemen than the field information indicates. Certainly the same terms, in the forms shirähah and shäribs (pl. sharah and shurrāh), have been recorded by R.B. Serjeant in Hadramawt as meaning respectively palm-protection and the one who protects the palms and other crops from the depredations of birds and raiders, though presumably not necessarily in the context of sharecropping ${ }^{\mathbf{0}}$.

10 Serjeant 1981a :307 ff; cf. Landberg 1920-42 :III, 2036, root sh-r-b: "Shärib pl. shurrāh, gardien des champs, lorsque le blé est déjà grand, ou gardien de bestiaux en général". The protective element in the duties of a sharecropper in northern Yemen will be referred to below in Chapter 8 . 
The distinction between owner-farmed land and sharecropped land is made in local terminology of ten by the use of the pair of terms ma $T a k \bar{\gamma}$ for the former and sharāk for the latter. In place of sharāk $\overline{7}$ the term arā $\overline{7}$ mushrakah was also recorded in the field survey.

As has been said above, ijärah and other derivatives from the same root are used as much in the context of sharecropping as that of fixed rent tenancies. If a distinction has to be made, the usual term used to differentiate a fixed rent tenancy from a crop-sharing agreement is qatc (literally, cut, and presumably implying clear-cut and hence fixed), and the fixed rent tenant is a qatic. The fixed rent itself is described as shay' mac Tum or shay' macrūf (something known or fixed [beforehand]). This implies that a rental under a sharecropping system is recognised and accepted as ghayr mac Tum (not known) beforehand.

\subsection{The Do inance of Sharecropping in the Yenen}

\subsection{Owner-Occupied Land versus Tenanted Land}

It was found impossible in any of the sample areas to estimate even approximately how much of the land is matakj (owner-farmed), how much is tenanted for shay' mac Tum (a fixed rent), and how much sharāk $\overline{7}$ (sharecropped). There were three reasons for this.

First, to collect such data for even the sample areas of the present field study would have meant a substantial survey of a scope far greater than could be attempted by an individual researcher within a reasonable time framel1. Some official statistics and other studies do exist which purport to give the breakdown between owner-occupied land and leased land, but their results are difficult to compare with each other, possibly partly because of different definitions of the categories $\mathbf{1 2}$.

11 Cf. M.W. Mundy (1981:64), who found it impossible to estimate even in general terms the proportion of land under sharecropping arrangements in her study area of wädi Zahr (to the north of $\left.\operatorname{San}^{c^{a}} \bar{a}^{\prime}\right)$. 
Second, even reliable statistics would be reliable only for a very short time. In the 1990 s in particular, the land tenure situation has been in a state of flux, especially perhaps in the capital area, as both landowners and tenants decide to move to Sanc $\bar{a}$ ' or towns elsewhere, or, after having built up sufficient capital through working in the towns, move eventually back home to agriculture. This population movement between country and town and vice versa seems to have been particularly marked since 1990 , largely as a result of the combined effects of, first, the unification of North Yemen with the former PDRY in that year and the resultant free movement of "cAdanis" northwards, and second, the Gulf War of 1991 when most emigrant Yemenis working in the Gulf emirates and Saudi Arabia were forced to return home13.

Third, and most saliently, the distinction between landowners and tenants, whether those on a fixed rent basis or as sharecroppers, is not clear cut. Some tenants are also landowners and either add to the land they cultivate as their own by renting someone else's, or else are tenants in one area and owners in another. This was found particularly at al-Hājir $\bar{i}$ and in Wâd $\bar{i}$ Zahr (both to the north of Sancia'), and also more generally throughout all the areas visited. It is not surprising therefore that almost everyone who was approached for interview in the survey was involved in sharecropping in one way or another, either as landowner or as tenant or of ten as both.

12 For example, a landowner may choose to work his land jointly in association with a tenant, so that the distinction between owneroccupied and tenanted is blurred. Again, it is never clear to what extent should be included land which is cropped perhaps only once in several years (and which will almost certainly have a different tenurial pattern associated with it as a result). Such relevant statistics as are available from other sources, including the UN study of Yemeni sharecropping (UN 1987), and the difficulties of interpreting them, will be enlarged on below.

13 As was mentioned in Chapter 1 (Section 1.33 above), the Yemen government was understood by other Arab governments of the peninsula to support Iraq and as a result the Yemeni workers in Saudi Arabia and the Gulf emirates were expelled. 


\subsection{The 1987 UN Report on Land Tenancy in the Northern Yemen}

There has been one study which gives some information on the proportion of farms which are owner-occupied as opposed to those which are sharecropped, albeit for only a few sample areas. The study of sharecropping and tenancy practices in the northern Yemen (then the Yemen Arab Republic) carried out by a specialist team from the United Nations Joint Economic and Social Commission for Western Asia and the Food and and Agriculture Organisation in the mid 1980s provides such tenancy information for 263 farms spread between eighteen sample districts in Tihämah, the Southern Uplands (TacizzIbb-Yarīm) and the $S^{c} \bar{a}^{\prime}$ area14. The UN project team classified farms into three tenure categories: "Owned Farms" (that is, those worked by their resident owner and often referred to in other studies as owner-farmed or owner-occupied farms); "Rented Farms" (that is to say, those worked by a tenant, whether on a sharecropping basis or a fixed rent basis); and "Mixed Farms" (presumably those on which part of the land is worked by the owner and part by a tenant, though this is not explained in the report).

Briefly, the findings of the UN team on the frequency of owneroccupancy versus tenancy were as follows 15 . The frequencies of the three tenure categories were $61 \%$ Owned, 19\% Rented and 20\% Mixed for the total sample of 263 farms $^{16}$. The farms in the UN sample that

14 UN $1987: 3-4$. The Southern Uplands region of the UN report covers the area around $\mathrm{Ta}^{\mathrm{c}} \mathrm{izz}$, Ibb and Yarim and therefore coincides with the region called in this present thesis the Southern Mountains, though (by including Yarim) with the addition of the southern part of the Central Plateaux.

15 The following information has been extracted mainly from Tables 1-4 of the UN report (UN $1987: 5-7$ ).

16 These figures contrast with the officially published figures for approximately the same year. In terms of the area of agricultural land: $77.4 \%$ was owner-occupied (mi $7 k), 3.8 \%$ was rented for a fixed rent ( $\bar{\jmath} \bar{\jmath} r$ ), and $18.8 \%$ was sharecropped (sharäkah), as quoted from the official statistics for 1983 by Abū Ghānim 1990 :304-05, though because the official statistics have no category called "mixed", and yet distinguish between rented for a fixed rent and sharecropped, they are not directly comparable with the UN figures. 
were tenanted or partly tenanted (that is, in the terms of the report, the Rented Farms and the Mixed Farms taken together) amounted to $39 \%$ of the total sample (103 farms out of 263), though there was a large variation with region and district. Thus although in Tihämah $43 \%$ of the farms were tenanted or partly tenanted overall, the actual proportion varied between $68 \%$ in Wâdi Rimac (19 farms out of a sample of 28) and only $26 \%$ in Wādi Mawr (9 farms out of 35). Again, the average for the Southern Uplands was $39 \%$ tenanted or partly tenanted, though at Ibb it was 53\% ( 9 farms out of 17) and at $\mathrm{Ta}^{\mathrm{c}} \mathrm{izz}$ only $30 \%$ (12 farms out of 40 ).

Regarding the frequency of sharecropping tenancies versus fixed rent tenancies, the UN report found that sharecropping tenancies were overwhelmingly more common $\mathbf{1 7}^{\mathbf{7}}$. In Tihāmah they accounted for $92 \%$ of the sample tenanted farms ( 54 farms), fixed rent existing on only the remaining $8 \%$ ( 5 farms), while in the Southern Uplands and the Sanc $\bar{a}$, area the preponderance of sharecropping was even greater, with $96 \%$ of the tenanted farms ( 44 farms) under sharecropping and only 4\% (2 farms) with fixed rent. Further, according to the UN field data, sharecropping was particularly common on land dependent entirely on rain and rather less common on land watered by a pump well. Conversely, the UN team recorded no cases of fixed rent on rain-dependent land and only one case on sayl-watered land. The authors of the report rightly explain this distribution as a result of the fluctuation in rainfall from season to season and the preference therefore for sharecropping on such lands, an explanation which has already been mentioned in this thesis when the rationale of sharecropping was discussed (Chapter 2, Section 2.2).

17 The terminology the UN report uses can be criticised: in it, by "rent in kind" the authors evidently mean sharecropping, and by "rent in cash" they mean fixed rent. That this must be so is clear from the last sentence on p. 5 of the report (UN 1987). As was pointed out above in Chapter 2 (Section 2.21) and as will be shown again later in this chapter (Section 6.44) the categorisation of tenancies into sharecropping and fixed rent is quite distinct from the categorisation into rent paid in cash and rent paid in kind: both sharecropping rents and fixed rents may be paid either in cash or in kind. 
How all the figures in the UN report relate to the present field survey data is virtually impossible to say. First, as has been mentioned above, the figures vary considerably from district to district, and none of the sample districts chosen by the UN team coincides exactly with the sample areas of the present survey. Second, the UN data refers to the position in the mid 1980s (specifically, late 1985 and early 1986, the period when UN team carried out their field work), whereas the present survey material was gathered mostly in mid-1993, as has been mentioned (Section 6:21 above). In the seven and a half years between the two surveys the Yemen had undergone much social and economic change, including especially the effects of the unification between the Yemen Arab Republic and the People's Democratic Republic of Yemen and the forced return of expatriate Yemeni workers from Saudi Arabia and the Gulf states in the aftermath of the war against Iraq. Clearly therefore the results of the UN survey are not directly comparable with those of the present survey. Nevertheless, in at least one general finding, namely, the great preference for sharecropping tenancies over fixed rent tenancies, the situation as recorded by the UN survey reflects that encountered in the present survey as will now be shown.

\subsection{Sharecropping versus Fixed Rent Tenancies, according to the} present survey

From the 66 interviews 136 cases of rental systems were extracted. These "cases" are not cases of individual farmers, but rather instances the farmers, landowners and others gave of types of rental systems. An individual landowner may have different systems in operation on different parts of his land - for different crops, for example, or for different sources of water. Equally, a tenant might well pay a fixed rent on part of the land he farms, and different percentages of the crop under different sharecropping systems on other parts, according to different crops or water sources or to different landowners. Again, a farmer may be a landowner who lets his own land to a tenant under one rental system while at the same time farming another landowner's land as a tenant in another 
district under a different system. The same kind of complexity in land tenure has also been noted by other researchers in the Yemen $\mathbf{1 8}$. Asking a farmer "What rental system do you use?" therefore frequently produces several answers. It is these answers then which are the basis of the cases considered here. Table 6.2 summarises the overall situation as reflected in the 66 interviews.

Table 6.2 : LAND ANI WATER RENTAL : OVERALL VIEW

\begin{tabular}{|c|c|c|c|c|}
\hline System & $\begin{array}{l}\text { Land and water } \\
\text { or land only } \\
\text { rented }\end{array}$ & $\begin{array}{l}\text { Water } \\
\text { only } \\
\text { rented }\end{array}$ & Total & $\begin{array}{l}\text { cases } \\
.(\%)\end{array}$ \\
\hline Fixed Rent & 14 & 1 & 15 & $(11.0 \%)$ \\
\hline Sharecropping & 118 & 3 & 121 & $(89.0 \%)$ \\
\hline Totals: & 132 & 4 & 136 & (100.0\%) \\
\hline
\end{tabular}

Source: Field Survey.

As can be seen from this table, of the 132 cases of land rental the tenant paid a fixed rent to the landowner in only fourteen. In the remaining 118 the land rental was expressed and paid in terms of a proportion of the harvest under one or other of the many sharecropping systems to be identified below in Section 6.5. In the four cases recorded where a landowner rented water only and not land from a third party and then used it on his own land, the amount of the rental was a proportion of the harvest in three of them. Overall, therefore, sharecropping accounts for $89 \%$ of the cases in

18 For example, by Escher (1976:83-85) in Wādī Mawr; by Makin ((ed.) $1977: 56)$ in lower Wādī Rimac; and by Mitchell (1978:22 and 56-58) in lower Wâdi Mawr and in the area between $\mathrm{Ta}^{c} \mathrm{izz}$ and al-Turbah. As has already been mentioned, the 1987 UN report had to include a category of "Mixed Farms" which were partly leased and partly owner-occupied and this category accounted for a substantial proportion of the total sample. 
the present survey and fixed rent only $11 \%$, a situation broadly similar to that found in the UN report as discussed above. This finding also agrees with observations and conclusions from other researchers and agricultural consultants who have worked in the Yemen, though the fact tends to be passed over by them without more than a brief comment ${ }^{19}$. It is likely therefore that the finding of the present survey that sharecropping as a rental system is overwhelmingly more important than fixed rent payment reflects the situation in northern Yemen as a whole.

\subsection{Fixed rent tenancies}

Table 6.2 above shows that only 14 cases of fixed rent tenancy for land and one case of fixed rent tenancy for water only emerged from the 136 cases found in the interview survey. These are broken down by source of water in Table 6.3. Because of the small numbers of cases involved, no generalized conclusions.can be drawn from this distribution by water source beyond the comment that instances of fixed rents were found in land watered by all sources of water except sayl (which were in any case few in number in the survey) but that they formed only a small proportion of the total cases of land tenancy.

19 The predominance of crop-sharing has also been remarked in passing by Escher $1976: 82 \mathrm{ff}$. and Mitchell et al. $1978: 43$ (both in lower Wādi Mawr); and Mundy $1981: 62$ (in Wādi Zahr); and the finding is in line also with the 1983 figures quoted by Abü Ghänim (1990 :304-05) and given in Note 16 above. 
Table 6.3 : LAND AND WATTR RENTAL :

FIXED RENT SYSTEUS BY SOURCE OF WATER

$\mathrm{N} \mathrm{u} \mathrm{m} \mathrm{b} \mathrm{e} \mathrm{r}$ of $\mathrm{c}$ a s e s
rain ghayl sayl well source not Total
specified

Cases of fixed rental for

land (or land and water): $\begin{array}{lllllll}3 & 4 & - & 4 & 4 & 14\end{array}$

Cases of fixed rental for

water only:

$-$

$1-$

1

$\begin{array}{lllllll}\text { Total fixed rental cases: } & 3 & 4 & - & 5 & 4 & 15\end{array}$

Source: Field Survey.

of the 14 cases of fixed rents for land (or land and water), details were recorded of the rent for ten cases. These ten are shown in Table 6.4. It will be noted from this table that these rents are quoted in terms of a volume of grain (or its value) per area of land per year in all the cases in which rain and ghayl were the source of water, but that in the cases in which the water was from wells the rent is quoted in terms of Yemeni riyāls per unit area. Since the sample is so small no general conclusions can however be safely drawn from this, and further, comparison between the various cases is extremely difficult because of the wide variation in the sizes of both areal units and units of capacity throughout Yemen ${ }^{20}$. Nevertheless, the information does clearly 
Table 6.4 : LAND RPNTAL : DETAILS OF FIXXD RENTS

\begin{tabular}{|c|c|c|c|c|}
\hline $\begin{array}{l}\text { water } \\
\text { source }\end{array}$ & location & crops & $\begin{array}{l}\mathrm{Det} \text { a } \mathrm{i} \mathrm{l} \mathrm{s} \text { of } \\
\text { units as given by } \\
\text { respondents } \\
\text { per year }\end{array}$ & $\begin{array}{l}\frac{\mathrm{f} x \mathrm{e} d \mathrm{~d} \mathrm{e} \mathrm{t}}{\text { approximate }} \\
\text { metric equiv. } \\
\text { per year }\end{array}$ \\
\hline rain: & Shiban & grains & 3 qadabs / 25 libnah & $123 \mathrm{li} . / 1875 a^{2}$ \\
\hline \multirow[t]{5}{*}{ ghayl: } & al-Ahjur & grains & $\begin{array}{l}\frac{1}{2} \text { qadab / libnah } \\
\quad+3 / 4 \text { of the sugarcane crop }\end{array}$ & $20 \frac{1}{2}$ li. $/ 75 \mathbb{1}^{2}$ \\
\hline & al-Ahjur & regetables & $\begin{array}{l}\text { value of } \frac{1}{2} \text { qadab sorghum } \\
\qquad / \text { libnah }\end{array}$ & $20 \frac{1}{2}$ li. / $75 m^{2}$ \\
\hline & al-Ahjur & tree fruits & 1 thumanini / libnah & 5 li. $/$ is \\
\hline & Dhî al-Sufall & grains & 3 thumnats & $15 \frac{1}{2} \mathrm{li}$ \\
\hline & Dhî al-Sufal & vegetables & $\frac{1}{2}$ qadab & $20 \frac{1}{2}$ li. \\
\hline \multirow[t]{3}{*}{ we11: } & cAarān & vegetables & YR 400 / libnah & YR $400 / 75 \mathbb{1}^{2}$ \\
\hline & al-Suwayq & [not specified] & YR $1000 / m a^{\bar{c} a d}$ & YR $1000 / 4000 m^{2}$ \\
\hline & al-Suwayq & [not specified] & YR $1000 / m a^{\bar{c} a d}$ & YR $1000 / 4000 \mathbb{m}^{2}$ \\
\hline unspecified: & al-Suwayq & [not specified] & YR $500-700 / \mathrm{ma} \overline{a^{2} d}$ & YR $500-700 / 4000 \mathbb{a}^{2}$ \\
\hline
\end{tabular}

20 See the notes accompanying Table 6.4. 


\section{Units of Capacity:}

The qadab is a large measure of capacity widely used in Yemen. The unit varies in size according to region but the $\operatorname{San}^{\mathrm{a}} \overline{\mathrm{an}} \overline{\mathrm{i}}$ qadah is extensively known and quoted and is generally equivalent to around 41 litres. The thumān $\overline{7}$ and thumnah are medium-sized units of capacity widely used on the high plateaux and in the mountains of northern Yemen, the former north of Sanc $\bar{a}$, and the latter to the south. Generally, eight of either make a qadah, and although the units vary in size according to region, they tend to be equivalent to about five litres. For a fuller discussion on Yemeni units of capacity, see Donaldson 1996.

\section{Units of Area:}

The libnah or 7ubnah is an areal measure used widely on the high plateaux and in the mountains of the northern part of Yemen north of Yarim. It varies widely in size from $16 \times 16$ dhira $\bar{a}^{c}$ (cubits) in some areas to as little as $10 \times 10$ dhirác in other areas, and the fact that the dhiräc is also variable makes calculating metric equivalents very problematic. An arbitrary standard for the libnah of $75 \mathrm{~m}^{2}$ has been used in calculating the metric equivalencies in the above table. The macād is a large unit of areal measurement used on the plain of Tihämah but not in the mountains or on the plateaux. It varies between about $3,300 \mathrm{~m}^{2}$ and $4,356 \mathrm{~m}^{2}$, according to district. An arbitrary standard of $4,000 \mathrm{~m}^{2}$ has been adopted in calculating the metric equivalencies above. 
underline the point already made (Section 2.21) that fixed rents can perfectly well be quoted and paid in kind (caynan) as well as in cash (naqdan).

\subsection{Sharing Systems}

\subsection{General Considerations}

The systems for dividing the crop between landowner and sharecropper (and where a pump well is involved, the pump owner also) are so various in Yemen that generalisations are very difficult to make 21 . Even within restricted areas there is no simple relationship between the various crop-sharing systems and any of the identifiable factors which might influence them. Within a single valley or village the variation in systems can be great and an individual farmer may be involved in several systems at once. Despite the variety of systems it is however noteworthy that during the field survey in the Yemen no example was ever found of the type of sharecropping system which the Prophetic bad7 ths explicitly forbid and which was discussed at some length in Chapter 3 (Section 3.33) and in Chapter 5 (Section 5.3) above: that is, the system in which the crop is divided by area, with one party taking his share from one plot of the land and the other party taking his share from another plot. It is, of course, practically impossible to decide whether or not the absence of such a system in present day Yemen is the result of farmers consciously obeying the Prophetic injunction.

From the respondents in the field survey 17 separate sharecropping systems were identified, of which two concern cases where water only (and not land) was being rented. These are shown in Table 6.5, labelled A to S (omitting $I$ and $O$ ) and arranged according to the size of the landowner's share. Systems A to $\mathrm{K}$ involve contracts in which there are only two parties (the landowner and the tenant), whereas systems $\mathrm{L}$ to $\mathrm{Q}$ have a water owner as a

21 The picture painted of sharing systems by Abū Ghānim (1990 :304), for example, is very much a simplification of the actual situation. 
Table 6.5 : LAND AND WATER RENTAL : CROP SHARING SYSTENS

Landowner : Sharecropper

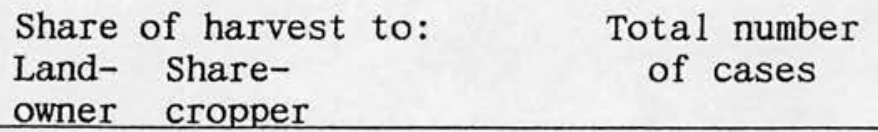

$\begin{array}{lll}\mathrm{A} & 4 / 5 & 1 / 5 \\ \mathrm{~B} & 3 / 4 & 1 / 4 \\ \mathrm{C} & 2 / 3 & 1 / 3 \\ \mathrm{D} & 1 / 2 & 1 / 2 \\ \mathrm{E} & 1 / 3 & 2 / 3 \\ \mathrm{~F} & 1 / 4 & 3 / 4 \\ \mathrm{G} & 1 / 5 & 4 / 5 \\ \mathrm{H} & 1 / 6 & 5 / 6 \\ \mathrm{~J} & 1 / 8 & 7 / 8 \\ \mathrm{~K} & 1 / 10 & 9 / 10\end{array}$

1
4
3
33
26
23
5
3
2
1

$\overline{101}$

Landowner : Sharecropper : Water Owner

\begin{tabular}{ccccc} 
& $\begin{array}{c}\text { Share of harvest to: } \\
\text { Land- } \\
\text { owner }\end{array}$ & $\begin{array}{c}\text { Share- Water } \\
\text { cropper }\end{array}$ & $\begin{array}{c}\text { Total number } \\
\text { of cases }\end{array}$ \\
\hline L & $1 / 3$ & $1 / 3$ & $1 / 3$ & 3 \\
M & $1 / 4$ & $1 / 2$ & $1 / 4$ & 1 \\
N & $1 / 4$ & $1 / 4$ & $1 / 2$ & 6 \\
P & $1 / 6$ & $1 / 3$ & $1 / 2$ & 6 \\
Q & $1 / 8$ & $3 / 8$ & $1 / 2$ & 1 \\
& & & & $\underline{17}$
\end{tabular}

Landowner : Water Owner

Share of harvest to:

Land- Share- Water

Total number

owner cropper owner

of cases

\begin{tabular}{lllr}
$\mathrm{R}$ & $1 / 2$ & $1 / 2$ & 2 \\
$\mathrm{~S}$ & $1 / 3$ & $2 / 3$ & 1 \\
& & & -3 \\
\hline
\end{tabular}

Total sharecropping cases: 
third party. In systems $R$ and $S$ it is not land that is being leased but water, and so there are two parties, landowner and water owner.

As can be seen from the table, the proportion of the harvest paid to the landowner for the use of the land varies from $4 / 5$ in one case to only $1 / 10$ at the other extreme. The proportion retained by the tenant varies conversely: from as high as $9 / 10$ in one case to as low as $1 / 5$ in another. However, by far the most common systems are by halves, thirds or quarters. Of the 101 cases where only two parties are involved (systems $A$ to $K$ ), system $D(1 / 2: 1 / 2)$ accounted for one-third of the total, and system $E(1 / 3: 2 / 3)$ and system $F(1 / 4: 3 / 4)$ for about one-quarter each. Of the 17 cases where a water owner is involved as a third party, two-thirds are accounted for by systems $N$ and $P(1 / 4: 1 / 4: 1 / 2$, and $1 / 6: 1 / 3:$ $1 / 2$ ). In contrast, division by fifths, sixths, eighths or tenths is very much less common, though still significant in some instances. Other researchers and agricultural consultants working in the Yemen have reported a similar wide range of variation. In the 1987 UN report, which has already been referred to above, a total of at least 11 different systems are recorded and most of them similarly involve splitting by halves, quarters and thirds 22 .

There are undoubtedly many factors underlying the variability of these sharecropping systems. Several can be identified in terms of which the data are amenable to analysis, though even in combination they cannot explain the variability wholly. One factor - whether the supplier of agricultural inputs (notably seed and fertiliser) is the landowner or the sharecropper - has already been noted above in Chapter 2 (Section 2.23) and it was shown there that the degree to which the landowner contributes will influence the size of his share, even though often only theoretically. This was found to be generally applicable in the field survey concerning the supply of seed and fertiliser though variation was very marked and not always reflected in practice. The relationship was most evident in the case of the supply of water, as will be shown below.

22 UN $1987: 22-24$. 
Potential factors which can be considered here are: (1) the nature of the source of water; (2) the region in which the cases were recorded; (3) the type of crops grown; (4) the nature of the landowner (whether a private individual, a waqf or the state).

\subsection{Crop-sharing systems by Source of Water}

Table 6.6 shows the position when broken down by the source of water. From this table it can be seen that almost half the 121 sharecropping cases found in the field concerned land watered by wells (58 cases) and that most of the remainder were of tenancies on rain-fed land (35 cases). Only five cases applied to water from a sayl source, though as was pointed out above (Section 6.22), the low showing of sayl cases is to do with the deficiencies of the survey coverage and does not represent the importance of say 7 in the Yemen as a whole.

In the cases which involved ghayl irrigation the landowner received either a half or a third of the harvest and the sharecropping tenant either a half or two-thirds. No other cropsharing system was found with this source of water. Of the five cases of sayl irrigation, all but one gave the landowner similarly at least one-third of the harvest, and in one case (System A) as much as $4 / 5$ of the harvest, leaving only $1 / 5$ for the tenant.

With rain as the water source the share taken by sharecropping tenants was, on the whole, more generous. In over half these cases (18 out of the 35 cases of sharecropping on rain-fed land) the tenant received at least $3 / 4$ of the harvest, and in one case (System $\mathrm{J})$ as much as $7 / 8$. The landowner was therefore left with a proportionately smaller share on the whole than under ghay 7 and say 7 irrigation.

The greatest range of different systems was undoubtedly found in the cases which involved water from wells. In three cases (System B) the landowner took $3 / 4$ of the harvest, leaving the sharecropper with only $1 / 4$, while at the other end of the scale (Systems $\mathrm{J}, \mathrm{K}$ and $\mathrm{Q}$ ), the share of the landowner was only $1 / 8$ or $1 / 10$ of the harvest. Such differences between the water sources require explanation. 
Table 6.6 : LAND RENTAL AND SHARING SYSTTES BY SOURCE OF WATER

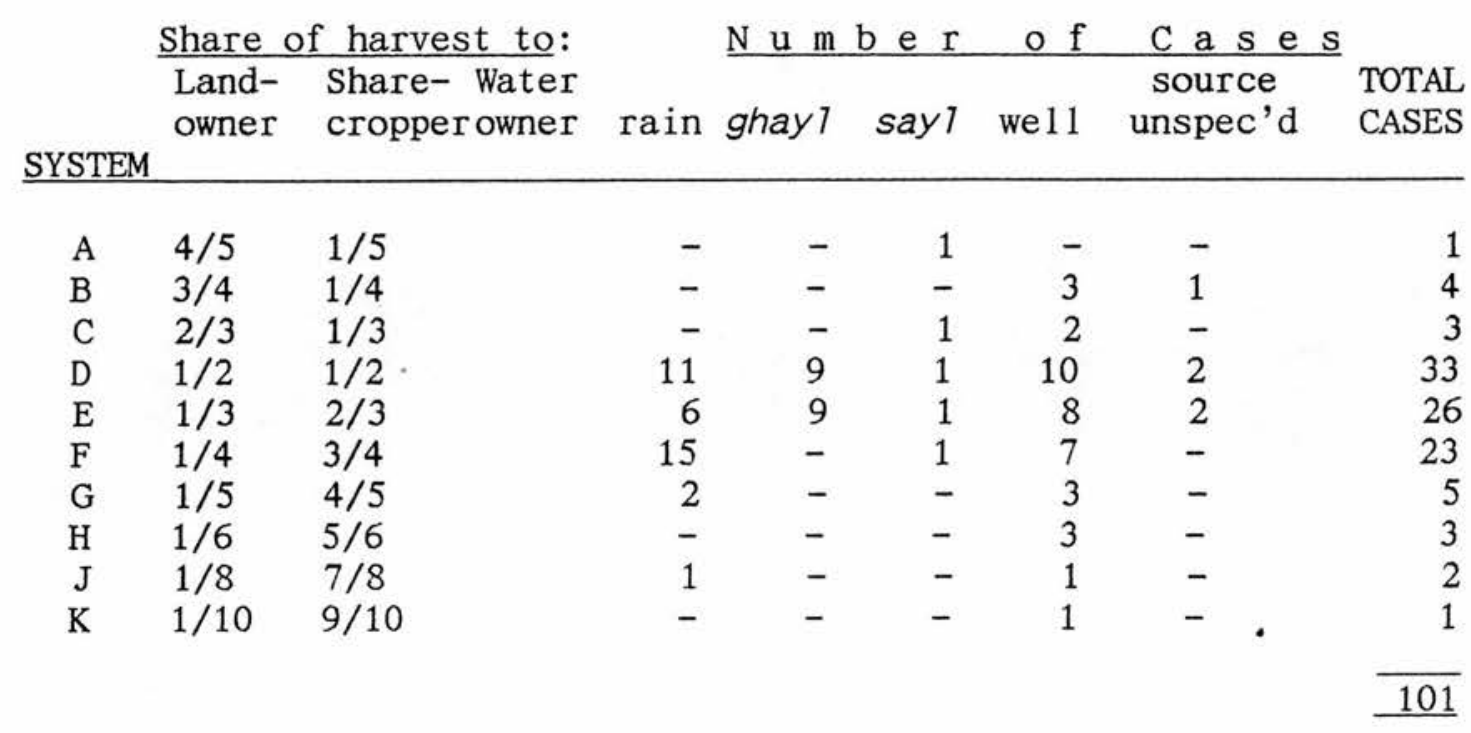

\begin{tabular}{lllllllllll}
$\mathrm{L}$ & $1 / 3$ & $1 / 3$ & $1 / 3$ & - & - & - & 3 & - & 3 \\
$\mathrm{M}$ & $1 / 4$ & $1 / 2$ & $1 / 4$ & - & - & - & 1 & - & 1 \\
$\mathrm{~N}$ & $1 / 4$ & $1 / 4$ & $1 / 2$ & - & - & - & 6 & - & 6 \\
$\mathrm{P}$ & $1 / 6$ & $1 / 3$ & $1 / 2$ & - & - & - & 6 & - & 6 \\
$\mathrm{Q}$ & $1 / 8$ & $3 / 8$ & $1 / 2$ & - & - & - & 1 & - & 1 \\
\hline
\end{tabular}

\begin{tabular}{lllllllll}
$\mathrm{R}$ & $1 / 2$ & $1 / 2$ & - & - & - & 2 & - & 2 \\
$\mathrm{~S}$ & $1 / 3$ & $2 / 3$ & - & - & - & 1 & - & 1 \\
& & & & & & & & \\
\hline
\end{tabular}

$\begin{array}{lllllll}\text { All sharecropping systems: } & 35 & 18 & 5 & 58 & 5 & 121\end{array}$

$\begin{array}{lllllll}\text { Fixed rentals: } & 3 & 4 & - & 4 & 4 & 14\end{array}$

Source: Field Survey. 


\section{(a) Land irrigated by ghayl and sayl}

The relatively large share for the landowner in most of the cases of ghayl and sayl irrigation can be largely explained, and is generally in the Yemen justified, by the fact that the water rights on land capable of being irrigated by these two sources of water is inalienable from the ownership of the land itself. In the case of ghayls, the use of the irrigation water is prescribed in detail according to tradition extending back in most cases probably many centuries in predominantly ghayl areas. According to the present survey informants, land which has ghay 1 rights is rarely if ever bought or sold without those rights. Even though there may be an active local market in selling ghayl water, especially in the rainless winter season, as occurs for example in both Dhi a $\overline{1}-\mathrm{Suf} \overline{1} 1$ and al-Ahjur, the market concerns sales by the hour or the day and not sales of the water rights separately from the land. In the case of sayl irrigation the rights to the spate.flow are riparian and are similarly attached to the land by long tradition. In both ghay 7 and say 7 irrigated lands the tenant is therefore renting not just the land but the water rights attached to it, and the relatively large share of the harvest that a sharecropper on such land delivers to the landowner reflects this fact.

(b) Rain-fed land

Land watered only by rain is of a different nature in two respects. First, rain water falling directly from the sky without any natural or artificial storage or channelling is regarded in Islamic law as mubāh - that is to say, ownerless and free to a1123. In reflection of this, in rural Yemen rain in the context of agriculture is of ten referred to not as matar or amtār (rain/rains) but by the periphrasis khayr AlTah subbān wa-tacāTa (the goodness of God). In contrast to ghayl and sayl, rain is in no sense a right attached to the land and the landowner has therefore no consequent right in either curf or Shar $\bar{i}^{c}$ ah to charge for it. This is

23 The term mubāh has also the wider meaning of $\overline{j a}$ 'iz, legal or permitted (for example, Doi (1984:50, 118)). 
reflected in the generally smaller share taken by the landowner and the more generous share allotted to the sharecropper when the sole source of water is rainfall.

A second difference from ghayl and sayl land which explains the generally higher share taken by the sharecropper on rain-fed land can also be identified and has in fact been already referred to above in the more general context in Chapter 2 (Section 2.24). By and large in many parts of the Yemen as in other arid or semi-arid environments, agriculture reliant solely on rain tends to economic marginality. If too large a share were to be exacted by a landowner then his tenants eventually would cease to survive and he himself would be the poorer in the long run. This 1 ine of reasoning was believed to be reflected in several of the interviews of the present survey by phrases such as caTa asās min macar al-sharīk (because of the poverty of the sharecropper) when the respondents were asked to explain the generally higher share for the tenant on rain-fed land.

\section{(c) Land irrigated by wells}

Land watered by wells contrasts with both rain-fed land and ghayl and sayl land. Unlike rain, well water is owned. Unlike ghayl and sayl, the rights to the water are not so firmly attached to the land.

The principles of water rights concerning wells in Islamic countries constitute a complex subject and have in any case been reviewed by other authors elsewhere ${ }^{24}$. In the present context, it may be stated briefly that the rights to ownership of water from wells stem from the costs (labour, materials, finance) which are expended first in digging the well and second in making the water usable (that is, bringing it to the surface). Water from a well on owned land is therefore not mubāb like rain, nor do the rights to it

24 Henri Bruno's doctoral thesis (Bruno 1913) seems to have been the first detailed study of Islamic water laws by a western lawyer. A more modern survey is FAO 1973 which provides a brief synthes is of the subject. For specifically the Yemen, see also Varisco 1982 :19-35 and Ch.6; and Maktari 1971a, especially Ch.1. 
stem wholly from its being attached to the land by tradition as in the case of ghayl and sayl water. As a result, it is very much more frequently the case than with ghayl and sayl water that a landowner or a tenant will rent water from the well of a neighbour, either for a fixed rent per hour or per day, or else, more commonly, under a sharecropping arrangement. For this reason, the water owner appears as a third party in a sharecropping agreement between a landowner and a sharecropper. Moreover, by far the majority of agricultural wells in the Yemen are nowadays worked by motor pumps (either added to traditional wells to replace animal power, or else, and increasingly, working in association with new tube wells), and consequently there will also be a pump owner. In most cases the owner of the pump will be one and the same with the owner of the we11, though this is not necessarily so. Any analysis of the situation is complicated further by the fact that the water owner may be a third party only notionally rather than a person distinct from the landowner and the sharecropper. Either of the latter two parties may be the notional third party, and in some cases both may actually own a share of the water in that they jointly own the pump.

It is for these reasons that the variety of sharecropping systems involving well water as they were quoted in the present survey appears very much greater than the range of systems for the other sources of water. The 1987 UN report on Yemeni sharecropping and land tenure already cited above similarly found that land irrigated by wells was subject to much greater variety of cropsharing systems than land watered by other means, though that report offered no explanations as to why this should be $\mathbf{s o}^{25}$.

To make the position clearer given the present figures, Table 6.7 has been extracted from the previous table (Table 6.6) and combined with other information from each case concerning water ownership. (Sharing systems $\mathrm{R}$ and $\mathrm{S}$ have been omitted since they concern rental of water only, not land, and there is therefore no ambiguity with these.)

25 UN $1987: 23-24$. 


\section{Table 6.7 : LAND RENTAL AND SHARING SYSTESS : WEIL WATER}

\begin{tabular}{|c|c|c|}
\hline $\begin{array}{l}\text { Share of harvest to: } \\
\text { Land- Share- Water } \\
\text { orner cropper owner }\end{array}$ & $\begin{array}{l}\text { Nunber of cases } \\
\text { involving well } \\
\text { water rental }\end{array}$ & $\begin{array}{l}\text { W a t e r o w n e r : } \\
\text { Land- Share- neigh- } \\
\text { omer cropper bour stated }\end{array}$ \\
\hline
\end{tabular}

$\begin{array}{lll}\text { B } & 3 / 4 & 1 / 4 \\ \text { C } & 2 / 3 & 1 / 3 \\ \text { D } & 1 / 2 & 1 / 2 \\ \text { E } & 1 / 3 & 2 / 3 \\ \mathrm{~F} & 1 / 4 & 3 / 4 \\ \text { G } & 1 / 5 & 4 / 5 \\ \text { H } & 1 / 6 & 5 / 6 \\ \text { J } & 1 / 8 & 7 / 8 \\ \mathrm{~K} & 1 / 10 & 9 / 10\end{array}$

$\begin{array}{rrrrr}3 & 3 & - & - & - \\ 2 & 2 & - & - & - \\ 10 & 7 & 1 & - & 2 \\ 8 & 2 & 5 & 1 & - \\ 7 & - & 6 & - & 1 \\ 3 & - & 3 & - & - \\ 3 & - & 2 & 1 & - \\ 1 & - & 1 & - & - \\ 1 & - & 1 & - & -\end{array}$

$\begin{array}{llll}\mathrm{L} & 1 / 3 & 1 / 3 & 1 / 3 \\ \mathrm{M} & 1 / 4 & 1 / 2 & 1 / 4 \\ \mathrm{~N} & 1 / 4 & 1 / 4 & 1 / 2 \\ \mathrm{P} & 1 / 6 & 1 / 3 & 1 / 2 \\ \mathrm{Q} & 1 / 8 & 3 / 8 & 1 / 2\end{array}$

$\begin{array}{lllll}3 & 2 & - & 1 & - \\ 1 & - & - & 1 & - \\ 6 & - & - & 5 & 1 \\ 6 & 2 & - & 4 & - \\ 1 & - & 1 & - & -\end{array}$

A11 sharecropping systems involving land and we11 water: 
In the systems where a share of the crop is specifically set aside for the water owner (Systems L to Q) the position is relatively straightforward. As can be seen in the table, the water owner may in any individual case be either the landowner (four cases) or the sharecropping tenant (one case) or a neighbour (eleven cases). As can also be seen from the table however, most of the systems ( $\mathrm{B}$ to $\mathrm{K}$ ) do not make any specific provision for the water owner in terms of a share of the crop. In one of these cases (under System E) the water owner was a third party, which requires explanation, though in all the others the water owner was either the landowner or the sharecropper.

In the cases where the share of the harvest to the landowner is $3 / 4$ or $2 / 3$, the water owner was also the landowner. That is to say, the sharecropping tenant was leasing from the landowner not only the land but also the water, and the landowner's share was consequently large relative to his own. Similarly, of the ten cases where the harvest was divided equally between landowner and sharecropper (System D), the landowner was also water owner in seven, and in only one known case of the ten did the sharecropper own the water. In this one known case (from an interview with a farmer in al-Mayfacah, between Dhamār and $\operatorname{Rad} \bar{a}{ }^{c}$ ), the pump and well were owned by a sharikah, a joint association of farmers each of whom had shares in the pump and one of whom was in fact the landowner.

In contrast, in all but four of the cases where the tenant's share was larger than the landowner's and no separate provision was made for the water owner (18 cases, Systems E, F, G, H, J and K), the table shows that the water owner was the tenant, which is what one would anticipate, given his large share. In the four exceptional cases (in Systems E and H), the water owner was either the landowner or a neighbour. In each of these four cases (one in Najr, one in al-Q $\bar{a}^{c} i d a h$, one in Shibām and one in al-Kahaylah) the sharecropper paid separately in cash for his water, or at least for the diesel to run the water pump, and consequently the supply of water in these cases lies outwith the crop sharing system.

With the exception of these very few cases in which water was paid for separately, all the sharecropping systems thus conform to a 
general principle that provision of water guarantees a share of the harvest whether or not this share is explicitly stated as a separate share. This applies as much to water-owning landowners and waterowning sharecroppers as to third party water owners since whichever party provided the water their share was larger in almost all cases.

On the basis of the above discussion as far as sharecropping on land watered by wells is concerned (though not land watered from other sources), it is possible therefore to rearrange the systems as they have been discussed until now and to combine some of them on the principle that a share of the harvest for the water owner is at least implicit in all the systems. This rearrangement is done in Table 6.8, with the new seven systems labelled I to VII. In Systems IV and VII the share of the notional third party water owner (the tenant in all four cases under these systems) has been assumed to be $1 / 2$ of the harvest since this is the most common proportion allotted to the water provider in the systems where.it is known and such a division provides a simpler residual for the tenant's share than either a third or a quarter would.

These seven systems form then the classification of sharecropping systems where wells are the water source and they will be used in future discussion. As can be seen, the number of sharing systems which involve wells has been reduced by this means from fourteen to seven, and of the 55 cases the large majority ( 31 cases) come under only two systems (Systems II and III) in both of which the water owner is more likely to be either the landowner or the tenant than a third party neighbour. This being the case, it is probably significant that these two systems are the only systems under which less than one-half the crop is assigned to him as notional third party water owner. In nearly all the remaining cases one of two other systems are used (18 cases, Systems I and V), and in these the water owner is most likely to be a third party neighbour rather than the landowner or the tenant and his share as third party water owner under both systems is one-half the crop. The tendency for third party water owners to take one-half the crop has also been found by the UN survey referred to above and also a 
Table 6.8 : LAND RFNTAL AND SHARING SYSTENS : WEIL WATER

\begin{tabular}{|c|c|c|c|c|c|c|c|c|}
\hline SYSTEM & $\begin{array}{l}\text { Share o } \\
\text { Land- } \\
\text { orner }\end{array}$ & $\begin{array}{l}\text { of harvest } \\
\text { Share- } \\
\text { cropper }\end{array}$ & $\begin{array}{l}\text { to: } \\
\text { Pater } \\
\text { owner }\end{array}$ & $\begin{array}{l}\text { Nuaber of cases } \\
\text { involving well } \\
\text { water rental }\end{array}$ & $\begin{array}{l}\text { W a } \\
\text { Land- } \\
\text { owner }\end{array}$ & $\begin{array}{l}\text { e I } \\
\text { are- } \\
\text { apper }\end{array}$ & $\begin{array}{l}\text { o w } \\
\text { Neigh- } \\
\text { bour }\end{array}$ & $\begin{array}{l}\text { e } r: \\
\text { not } \\
\text { stated }\end{array}$ \\
\hline I $(B \& N)$ & $1 / 4$ & $1 / 4$ & $1 / 2$ & 9 & 3 & - & 5 & 1 \\
\hline I I $(C, E \& L)$ & $1 / 3$ & $1 / 3$ & $1 / 3$ & 13 & 6 & 5 & 2 & - \\
\hline III $(D, F \& M)$ & $1 / 4$ & $1 / 2$ & $1 / 4$ & 18 & 7 & 7 & 1 & 3 \\
\hline IV (G) & $1 / 5$ & $3 / 10$ & $1 / 2$ & 3 & - & 3 & - & - \\
\hline 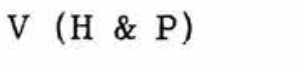 & $1 / 6$ & $1 / 3$ & $1 / 2$ & 9 & 2 & 2 & 5 & - \\
\hline VI $\left(\begin{array}{lll}J & \& & Q\end{array}\right)$ & $1 / 8$ & $3 / 8$ & $1 / 2$ & 2 & - & 2 & - & - \\
\hline VII (K) & $1 / 10$ & $2 / 5$ & $1 / 2$ & 1 & - & 1 & - & - \\
\hline
\end{tabular}

Al1 sharecropping systems

involving land and

well water:

$18 \quad 20 \quad 13$

4

Source: Field Survey. 
1977 UK Overseas Development Administration survey of lower Wādi Rimac in Central Tihāmah $^{26}$.

\subsection{Crop-sharing systems by Region}

The regions which have been used to classify the field locations on the basis of climate, water source and topography were given in Table 6.1 and Figure 6.1 above. Table 6.9 shows the 113 cases of sharecropping systems which involve land and for which the water source is recorded, as gathered from the 66 interviews and broken down by source of water and by region.

As may be observed from this table, the Central plateaux region has a wider variety of systems than the other regions in both rainfed land and well-irrigated land, but generally speaking one or two systems stand out as dominant in all the regions for a given source of water. These dominant systems, which are picked out in bold figures in Table 6.9, are shown together in Table 6.1027.

From these two tables, 6.9 and 6.10 , it can be seen that, according to the field information, a sharing system in which the landowner takes $1 / 4$ of the crop, leaving the sharecropper with $3 / 4$, is dominant on rain-fed land in all the regions in which rain figured as an important water source except the Northern Plateaux where all four cases involved a $1 / 2: 1 / 2$ system, while in the Southern Mountains $1 / 3$ of the harvest to the landowner and $2 / 3$ to the sharecropper was as common as the $1 / 4: 3 / 4$ system.

In the two regions in which ghayls are important, a $1 / 2: 1 / 2$ system was dominant in the Southern Mountains but in the Northern Mountains a system in which the landowner takes $1 / 3$ and the sharecropper $2 / 3$ was more common.

\footnotetext{
26 UN $1987: 23$; Makin (ed.) $1977: 57$.

27 The sayl-irrigated cases have been combined with the ghayl cases in this table since so few sharing systems involving say 7 were included in the field survey and yet in terms of water ownership both are similar in that water rights are attached to the land, as has been discussed above (Section 6.52).
} 


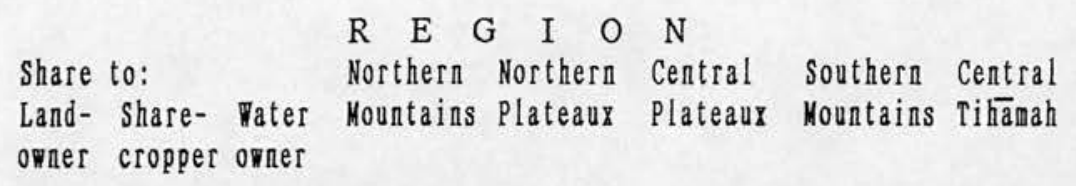

Al1 Regions

RAIN:

$\begin{array}{lll}\mathrm{D} & 1 / 2 & 1 / 2 \\ \mathrm{E} & 1 / 3 & 2 / 3 \\ \mathrm{~F} & 1 / 4 & 3 / 4 \\ \mathrm{G} & 1 / 5 & 4 / 5 \\ \mathrm{~J} & 1 / 8 & 7 / 8\end{array}$

1
$\overline{6}$
-
-

Total rain cases:

$7 \quad 4$

43

$-\quad 2$

2

211

$4 \quad-\quad 6$

- 2

2
1

2

$-$

$-$

GHAYL:

$\begin{array}{lll}\mathrm{D} & 1 / 2 & 1 / 2 \\ \mathrm{E} & 1 / 3 & 2 / 3\end{array}$

5
8

13

10

35

Total ghay 7 cases:

13

SAYL:

$\begin{array}{lll}\mathrm{A} & 4 / 5 & 1 / 5 \\ \mathrm{C} & 2 / 3 & 1 / 3 \\ \mathrm{D} & 1 / 2 & 1 / 2 \\ \mathrm{E} & 1 / 3 & 2 / 3 \\ \mathrm{~F} & 1 / 4 & 3 / 4\end{array}$

Total sayl cases:

$\begin{array}{ll}- & - \\ - & - \\ 1 & -\end{array}$

WELL:

\begin{tabular}{rlll}
\hline I & $1 / 4$ & $1 / 4$ & $1 / 2$ \\
II & $1 / 3$ & $1 / 3$ & $1 / 3$ \\
II I & $1 / 4$ & $1 / 2$ & $1 / 4$ \\
IV & $1 / 5$ & $3 / 10$ & $1 / 2$ \\
V & $1 / 6$ & $1 / 3$ & $1 / 2$ \\
VI & $1 / 8$ & $3 / 8$ & $1 / 2$ \\
VII & $1 / 10$ & $2 / 5$ & $1 / 2$
\end{tabular}

Total well cases:

$\begin{array}{ll}2 & 1 \\ 2 & 5 \\ 3 & - \\ - & 1 \\ - & - \\ - & - \\ - & -\end{array}$

7

7

19

1
1
$\mathbf{1 0}$
1
3
2
1

$\begin{array}{rrr}- & 5 & 9 \\ \mathbf{3} & 2 & 13 \\ \mathbf{4} & 1 & 18 \\ - & 1 & 3 \\ - & 6 & 9 \\ - & - & 2 \\ - & - & 1\end{array}$

Total cases

all water sources:

$27 \quad 13$

32

24

17

113

Source: Field Survey. 
Table 6.10 : DOMINANT SHARING SYSTENS BY REGION

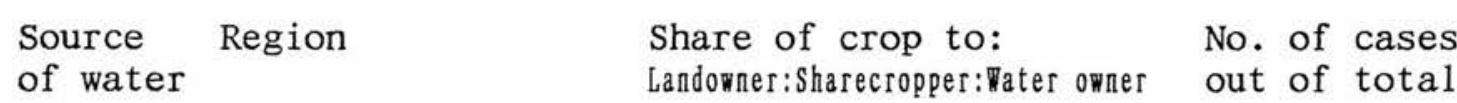

\begin{tabular}{|c|c|c|c|}
\hline \multirow[t]{4}{*}{ RAIN: } & Northern Mountains & $1 / 4: 3 / 4$ & 6 out of 7 \\
\hline & Northern Plateaux & $1 / 2: 1 / 2$ & 4 out of 4 \\
\hline & Central Plateaux & $1 / 4: 3 / 4$ & 5 out of 13 \\
\hline & Southern Mountains & $\begin{array}{l}1 / 4: 3 / 4 \\
1 / 3: 2 / 3\end{array}$ & $\begin{array}{l}4 \text { out of } 10 \\
4 \text { out of } 10\end{array}$ \\
\hline
\end{tabular}

GHAYL and SAYL:

$\begin{array}{lll}\text { Northern Mountains } & 1 / 3: 2 / 3 & 9 \text { out of } 15 \\ \text { Southern Mountains } & 1 / 2: 1 / 2 & 5 \text { out of } 7\end{array}$

\begin{tabular}{|c|c|c|c|}
\hline \multirow[t]{5}{*}{ WELL: } & Northern Mountains & $1 / 4: 1 / 2: 1 / 4$ & 3 out of 7 \\
\hline & Northern Plateaux & $1 / 3: 1 / 3: 1 / 3$ & 5 out of 7 \\
\hline & Central Plateaux & $1 / 4: 1 / 2: 1 / 4$ & 10 out of 19 \\
\hline & Southern Mountains & $\left\{\begin{array}{l}1 / 4: 1 / 2: 1 / 4 \\
1 / 3: 1 / 3: 1 / 3\end{array}\right.$ & $\begin{array}{l}4 \text { out of } 7 \\
3 \text { out of } 7\end{array}$ \\
\hline & Central Tihāmah & $\left\{\begin{array}{l}1 / 6: 1 / 3: 1 / 2 \\
1 / 4: 1 / 4: 1 / 2\end{array}\right.$ & $\begin{array}{l}6 \text { out of } 15 \\
5 \text { out of } 15\end{array}$ \\
\hline
\end{tabular}

Source: Field Survey. 
On land irrigated by wells in the Northern Mountains, the Central Plateaux and the Southern Mountains the crop was most usually split $1 / 4$ to the landowner, $1 / 2$ to the sharecropper and $1 / 4$ to the well and pump owner, though in the Northern Plateaux the most common system was $1 / 3$ to each of the three parties, while in Central Tihāmah two systems were almost equally common, in both of which half the crop goes to the water owner with either $1 / 3$ or $1 / 4$ taken by the sharecropper.

\subsection{Crop-sharing systems by Types of Crop}

As was mentioned above in Chapter 1 (Section 1.3), the crops which cover most of the agricultural land in the Yemen are grains, and of these the various varieties of sorghum are the most common."This preponderance of grains is reflected in the field survey material. Most other crops are cash crops, or may be treated as such. For this analysis the crops can be considered under the following main categories:
1) grains;
2) tree fruits (deciduous fruit, dates, coffee and bananas);
3) qāt;
4) vegetables (including potatoes);
5) other cash crops (cotton and tobacco).

Using the information derived from the 66 interviews, it is possible to break the sharecropping systems down on the basis of these categories of crops. This is done in Table 6.11.28 The table shows that on rain-fed land by far the most common sharing system

28 Many responses from the interview survey indicated that more than one crop in any given case was subject to the same sharing system. For example, one farmer might say that he had grain and vegetables under one system on rain-fed land and $q \bar{a} t$, tree fruit and other vegetables under another system on land watered by a well. Such an example would be included on the table as two cases on rainfed land and three cases on well-watered land. For this reason the numbers of cases in each water source category are larger than the numbers given in Table 6.6 and subsequent tables. 
Table 6.11 : SHARING SYSTIES BY CROP

Water share of crop to: grains tree gat vegetables other Total source Land- Share- Water- fruit cash cases for which owner: cropper: owner crops crop specified

\section{RAIN:}

$\begin{array}{ll:l}\text { D } & 1 / 2: 1 / 2 \\ \text { E } & 1 / 3: 2 / 3 \\ \text { F } & 1 / 4: 3 / 4 \\ \text { G } & 1 / 5: 4 / 5 \\ \text { J } & 1 / 8: 7 / 8\end{array}$

Total cases watered by rain:

$\begin{array}{rrrrrr}6 & - & 4 & - & - & 10 \\ 6 & 1 & 1 & 2 & - & 10 \\ 13 & 1 & 2 & 2 & - & 18 \\ 2 & - & - & - & - & \\ 1 & - & - & - & - & \end{array}$

$\begin{array}{lllllll}28 & 2 & 7 & 4 & - & 41\end{array}$

GHAYL:

$$
\begin{array}{cl}
\mathrm{D} & 1 / 2: 1 / 2 \\
\mathrm{E} & 1 / 3: 2 / 3 \\
\text { Total } & \text { ghay } 7-\mathrm{irrigated} \\
\text { cases: }
\end{array}
$$

$\begin{array}{llllll}7 & 4 & 3 & 3 & - & 17\end{array}$

E $1 / 3: 2 / 3$

$\begin{array}{llll}8 & 9 & 6 & 3\end{array}$

26

SAYL:

$\begin{array}{ll:l}\text { A } & 4 / 5: 1 / 5 \\ \text { C } & 2 / 3: 1 / 3 \\ \text { D } & 1 / 5: 1 / 2 \\ \text { E } & 1 / 3: 2 / 3 \\ \text { F } & 1 / 4: 3 / 4\end{array}$

Total say7-irrigated cases:

WELL:

\begin{tabular}{lrrrrrrrr} 
I & $1 / 4: 1 / 4: 1 / 2$ & 4 & 1 & - & 4 & 2 & 11 \\
II & $1 / 3: 1 / 3: 1 / 3$ & 8 & 1 & 4 & 5 & 1 & 19 \\
III & $1 / 4: 1 / 2: 1 / 4$ & 11 & 6 & 4 & 10 & 1 & 32 \\
IV & $1 / 5: 3 / 10: 1 / 2$ & 2 & 2 & - & 2 & 1 & 7 \\
V & $1 / 6: 1 / 3: 1 / 2$ & 7 & 3 & - & 7 & 1 & 18 \\
VI & $1 / 8: 3 / 8: 1 / 2$ & 2 & 1 & - & 1 & 1 & 5 \\
VII & $1 / 10: 2 / 5: 1 / 2$ & 1 & - & - & - & - & 1 \\
\cline { 2 - 7 } & & & & & & & &
\end{tabular}

Source: Field survey 
for grains is $1 / 4$ of the crop to the landowner and $3 / 4$ to the sharecropper (System F, 13 cases out of 28), whereas for qāt the crop is more frequently divided equally between the two parties (System D, four cases out of seven). The other categories of crops on rain-fed land have unfortunately too few cases for any generalisations to be made.

On ghayl-irrigated land, both grains and vegetables are most frequently shared on an equal basis between landowner and sharecropper (System D, seven cases out of eight for grain, and all three cases for vegetables), whereas for both tree fruit and qāt the cases are almost equally divided between a $1 / 2: 1 / 2$ system (System D) and a system under which $1 / 3$ goes to the landowner and $2 / 3$ to the sharecropper (System E). On sayl land the numbers are too small for any generalisations to be made.

On land irrigated by wells the position is more complex, largely because of the larger number of sharing systems involved. However, it may be remarked that the commonest system (System III, which gives $1 / 4$ of the crop to the landowner, $1 / 2$ to the sharecropper and $1 / 4$ to the water owner) is applicable irrespectively to grains, tree fruit and vegetables and also to half the cases involving qāt.

Tables 6.12 and 6.13 show the same information broken down by region, though, as was mentioned earlier (Section 6.22 above), these figures are simply what was found in the present survey and cannot be used as a basis to derive generally applicable conclusions. For such fine analysis a considerably larger initial field sample would have been required.

\subsection{Crop-sharing systems by Landowner}

The large majority of the land tenancy cases derived from the field survey concerned burr land (land owned by private individuals - 118 cases out of 132) as opposed to waqf land (13 cases) and säfiyah (government) land (only two cases). The waqf cases were found in all regions of the survey except the Northern Plateaux, though most were recorded in the Northern Mountains and the Central Plateaux, and both of the two săfiyah cases were noted in Central Tihāmah. 
Table 6.12 : DOMINANT SHARING SYSTFUS BY REGION BY CROP

\begin{tabular}{|c|c|c|c|c|c|c|}
\hline Region & Crop & $\begin{array}{l}\text { Water } \\
\text { source }\end{array}$ & $\begin{array}{l}\text { Shares } \\
\text { Land- } \\
\text { owner }\end{array}$ & $\begin{array}{l}\text { of cro } \\
\text { share- } \\
\text { cropper }\end{array}$ & $\begin{array}{l}\text { p to: } \\
\text { water } \\
\text { owner }\end{array}$ & $\begin{array}{l}\text { No. of cases } \\
\text { out of total }\end{array}$ \\
\hline
\end{tabular}

\section{NORTHERN MOUNTAINS:}

\begin{tabular}{|c|c|c|c|}
\hline grains: & $\begin{array}{l}\text { rain } \\
\text { ghayl } \\
\text { well }\end{array}$ & $\begin{array}{l}1 / 4: 3 / 4 \\
1 / 2: 1 / 2 \\
1 / 4: 1 / 2: 1 / 4\end{array}$ & $\begin{array}{l}6 \text { out of } 7 \\
2 \text { out of } 2 \\
2 \text { out of } 2\end{array}$ \\
\hline tree fruit: & $\begin{array}{l}\text { ghayl } \\
\text { well }\end{array}$ & $\begin{array}{l}1 / 3: 2 / 3 \\
1 / 4: 1 / 2: 1 / 4\end{array}$ & $\begin{array}{l}4 \text { out of } \\
2 \text { out of }\end{array}$ \\
\hline qāt: & ghay 7 & $1 / 3: 2 / 3$ & 3 out \\
\hline
\end{tabular}

\section{NORTHIERN PLATEAUX:}

$\begin{array}{llll}\text { grains: } & \text { rain } & 1 / 2: 1 / 2: & 2 \text { out of } 2 \\ & \text { well } & 1 / 3: 1 / 3: 1 / 3 & 5 \text { out of } 5 \\ \text { qät: } & \text { rain } & 1 / 2: 1 / 2: & 2 \text { out of } 2 \\ & \text { well } & 1 / 3: 1 / 3: 1 / 3 & 2 \text { out of } 2 \\ \text { vegetables: } & \text { wel1 } & 1 / 3: 1 / 3: 1 / 3 & 3 \text { out of } 3\end{array}$

\section{Central Plateaux:}

$\begin{array}{lllll}\text { grains: } & \text { rain } & 1 / 4: 3 / 4: & 4 \text { out of } 9 \\ & \text { well } & 1 / 4: 1 / 2: 1 / 4 & 5 \text { out of } 13 \\ \text { tree fruit: } & \text { well } & 1 / 4: 1 / 2: 1 / 4 & 3 \text { out of } 7 \\ \text { qät: } & \text { rain } & 1 / 2: 1 / 2: & 2 \text { out of } 2 \\ & \text { well } & 1 / 4: 1 / 2: 1 / 4 & 3 \text { out of } 3 \\ \text { vegetables: } & \text { well } & 1 / 4: 1 / 2: 1 / 4 & 5 \text { out of } 10\end{array}$

\section{SOUTHERN MOUNTAINS:}

\begin{tabular}{|c|c|c|c|}
\hline grains: & $\begin{array}{l}\text { rain } \\
\text { ghay } 7 \\
\text { wel1 }\end{array}$ & $\begin{array}{l}1 / 3: 2 / 3 \\
1 / 2: 1 / 2 \\
1 / 4: 1 / 2: 1 / 4\end{array}$ & $\begin{array}{lll}4 & \text { out of } \\
5 & \text { out of } 6 \\
4 & \text { out of } 5\end{array}$ \\
\hline tree fruit: & ghay 7 & $1 / 2: 1 / 2$ & 2 out of 3 \\
\hline vegeta & $\begin{array}{l}\text { ghayl } \\
\text { well }\end{array}$ & $\begin{array}{l}1 / 2: 1 / 2 \\
1 / 4: 1 / 2: 1 / 4\end{array}$ & $\begin{array}{l}3 \text { out of } \\
4 \text { out of }\end{array}$ \\
\hline
\end{tabular}

CENTRAL TIHĀMAH:

$\begin{array}{lcc:c:cl}\text { grains: } & \text { we11 } & 1 / 4: 1 / 4: 1 / 2 & 4 \text { out of } 10 \\ & n & 1 / 6: 1 / 3: 1 / 2 & 4 \text { out of } 10 \\ \text { vegetables: } & \text { we11 } & 1 / 4: 1 / 4: 1 / 2 & 4 \text { out of } 10 \\ & " & 1 / 6: 1 / 3: 1 / 2 & 4 \text { out of } 10 \\ \text { cotton: } & \text { we11 } & 1 / 4: 1 / 4: 1 / 2 & 2 \text { out of } 4\end{array}$




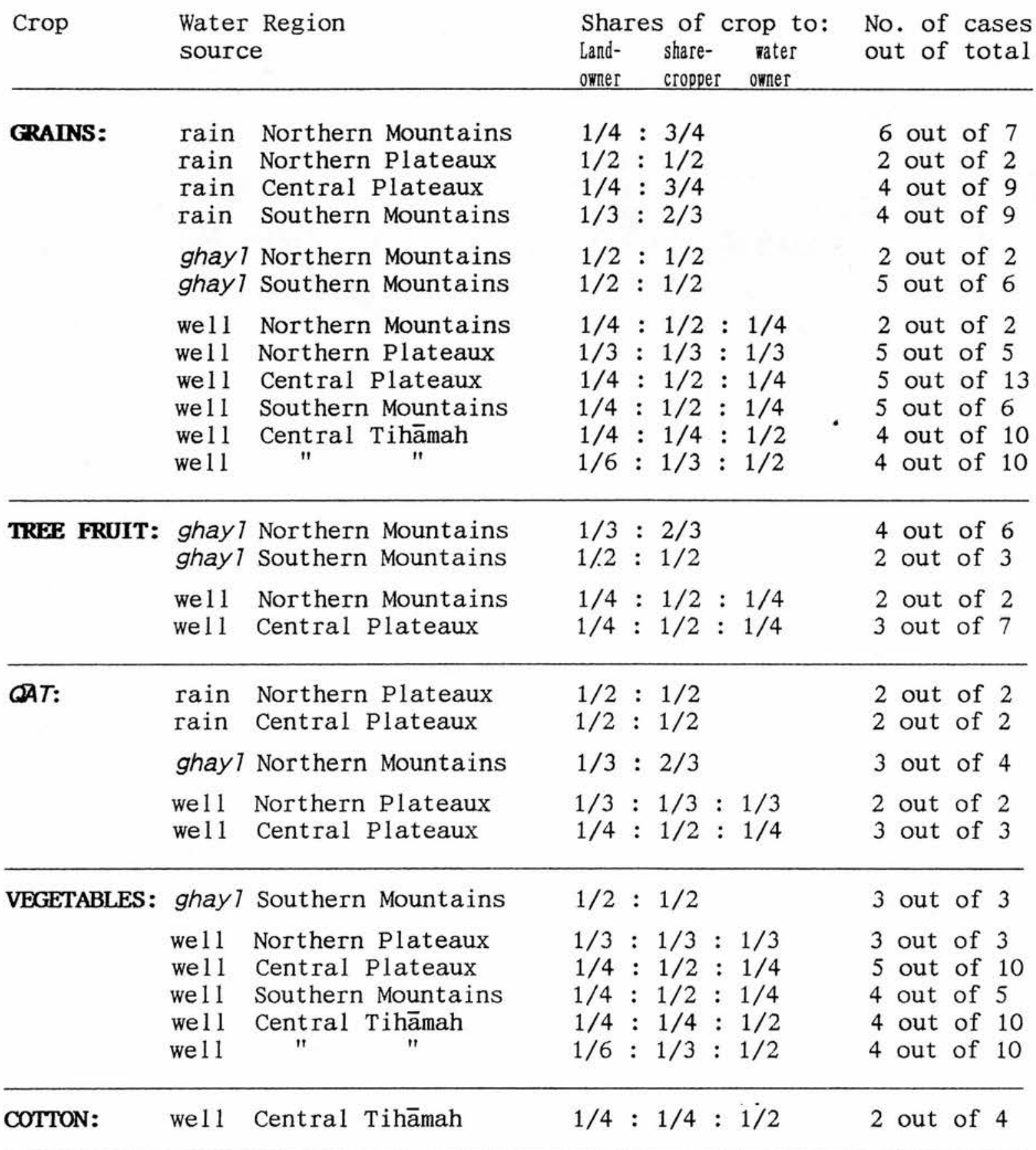


Because of the very small total numbers of cases however no general deduction can be drawn from this sample distribution, though from other field information it is probably the case that safiyah land is particularly common in Tihämah compared with other regions.

The cases are broken down by sharecropping system and source of water in Table 6.14. As can be seen from this table, one of the two säfiyah cases concerned fixed rent tenancy and the other a case of we11-irrigated land in which the crop was shared $1 / 6$ to the landowner, $1 / 3$ to the sharecropper and $1 / 2$ to the pump owner. In the instance of waqf land two cases involved fixed rents, the remaining 11 cases being cases of sharecropping. Of these 11 waqf cases only three gave the landowner as much as $1 / 3$ or $1 / 2$ of the harvest, and two of these concerned ghay 7 irrigation, while in five waqf cases the landowner's share was $1 / 5$ or less.

This distribution contrasts markedly with the sharing situation where the landowner was a private individual. Table 6.15, which summarises the position from the point of view of the landowner's share, makes this clearer. Although a landowner's share of $1 / 4$ of the crop is the most common system on both waqf land and privately owned land, a smaller share than $1 / 4$ is taken by the landowner in $50 \%$ of the cases of waqf (and safiyah) land but in only $12 \%$ of the cases on privately owned land. That is to say, a waqf landowner tends to take a smaller share of the harvest than a private landowner according to the cases from the field survey, and this conclusion agrees with more general statements of farmers in all areas visited which have waqf land: that waqf trustees are more generous landlords than are private individuals.

\subsection{Concluding Re-arks on the Current Yeneni Situation}

In the analysis of the crop-sharing systems in the sections above, all the results are strictly valid only for the specific settlements covered by the present field survey and only for the specific period of the survey (the summers of 1992 and 1993), and because of the small sizes of some of the subsamples no conclusions applicable to the northern Yemen as a whole can be made with certainty without corroborative evidence from other sources. On the other hand, there 
Table 6.14 : SHARING SYSTENS BY LANDOWNER

$\begin{array}{cllll}\text { Share of crop to: } & \text { waqf } & \text { säfiyah } & \text { privately } & \text { Total } \\ \text { Land- Share- Water } & \text { land } & \text { land } & \begin{array}{l}\text { owned } \\ \text { land }\end{array} & \text { cases } \\ \text { owner cropper owner } & & & \end{array}$

\begin{tabular}{ccc} 
RAIN: & & \\
\hline $\mathrm{D}$ & $1 / 2$ & $1 / 2$ \\
$\mathrm{E}$ & $1 / 3$ & $2 / 3$ \\
$\mathrm{~F}$ & $1 / 4$ & $3 / 4$ \\
$\mathrm{G}$ & $1 / 5$ & $4 / 5$ \\
$\mathrm{~J}$ & $1 / 8$ & $7 / 8$
\end{tabular}

$\begin{array}{rlr}- & - & 11 \\ 1 & - & 5 \\ 2 & - & 13 \\ 1 & - & 1 \\ 1 & - & -\end{array}$

Total rain cases:

5

30

35

$\frac{G H A Y L}{D}:$

D $\quad 1 / 2 \quad 1 / 2$

1 -

$\begin{array}{ll}8 & 9 \\ 8 & 9\end{array}$

Total ghayl cases:

2

16

18

SAYL:

$\begin{array}{lll}\mathrm{A} & 4 / 5 & 1 / 5 \\ \mathrm{C} & 2 / 3 & 1 / 3 \\ \mathrm{D} & 1 / 2 & 1 / 2 \\ \mathrm{E} & 1 / 3 & 2 / 3 \\ \mathrm{~F} & 1 / 4 & 3 / 4\end{array}$

Total sayl cases:

$\begin{array}{lll}- & - & 1 \\ - & - & 1 \\ - & - & 1 \\ - & - & 1 \\ - & - & 1\end{array}$

1

1

1

1

\section{Total sayl cases:}

WELL:

$\begin{array}{rlll}\text { I } & 1 / 4 & 1 / 4 & 1 / 2 \\ \text { II } & 1 / 3 & 1 / 3 & 1 / 3 \\ \text { III } & 1 / 4 & 1 / 2 & 1 / 4 \\ \text { IV } & 1 / 5 & 3 / 10 & 1 / 2 \\ \text { V } & 1 / 6 & 1 / 3 & 1 / 2 \\ \text { VI } & 1 / 8 & 3 / 8 & 1 / 2 \\ \text { VII } & 1 / 10 & 2 / 5 & 1 / 2\end{array}$

1
-
-
1
1
1

-
-
-
-
-

8

13

18

3

7

1

5

Total well cases:

4

1

50

9
13
18
3
9
2
1

55

Total cases for which water source known: 11

Cases for which

water source unknown:

$1 \quad 101$

113

Total sharecropping cases: 11

-

5

5

1106

118

Fixed rent cases:

2

1

11

14

Source: Field survey. 
Table 6.15 : SHARING SYSTFES BY LANDOWNER - SUMARY

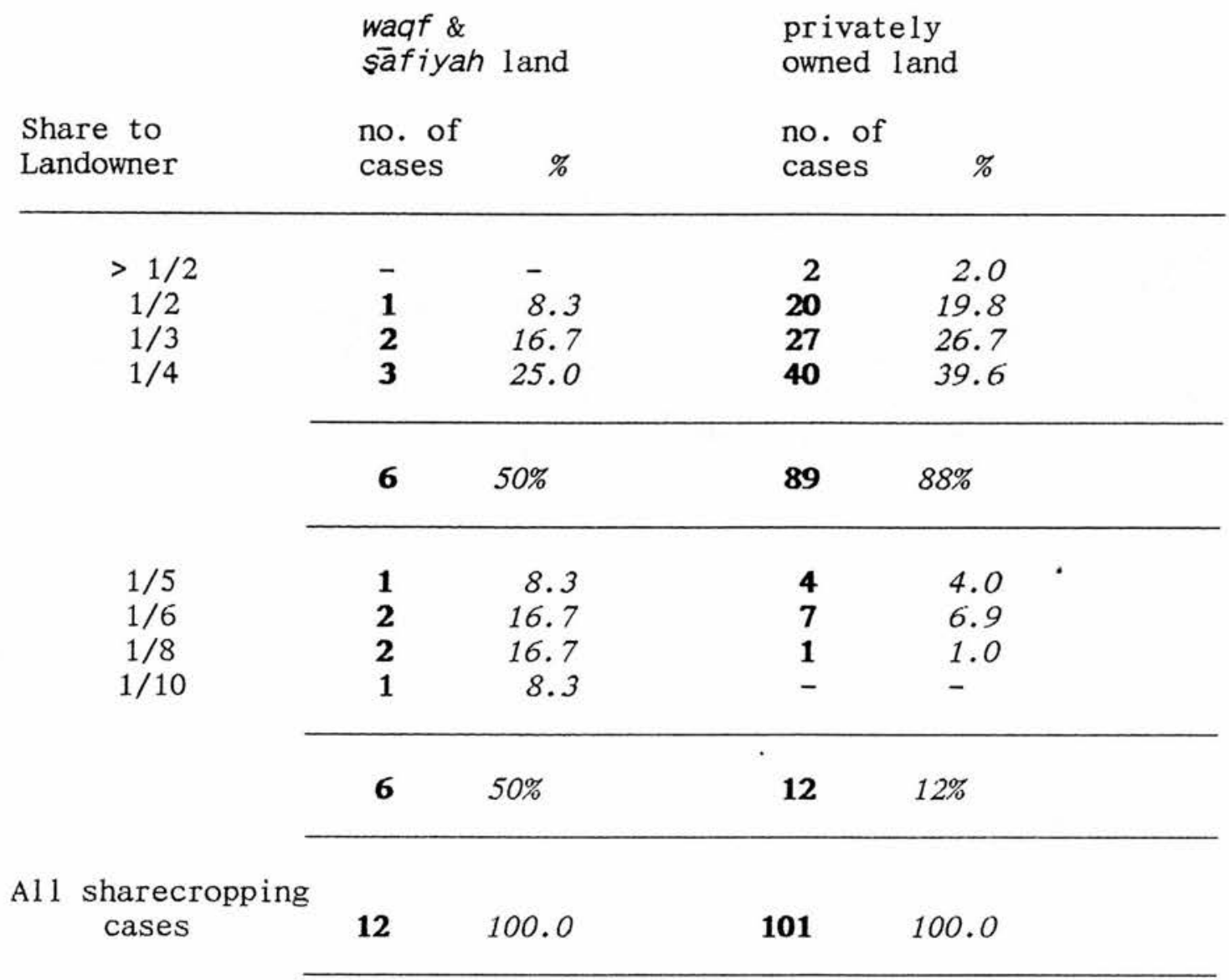

Source: Field Survey.

is great difficulty in finding such evidence. As D.M. Varisco has complained, the information on sharecropping in the Yemen as a whole is "often confusing and difficult to interpret, due to lack of specific information on the total context of application"29. What he had in mind was not only the considerable variability of the sharing systems from location to location and from one farmer to another, but also that that variability can be interpreted only in relation to crops, soil fertility, method of irrigation, and so on, which is generally the kind of detail that is not given by most of the available field studies. Despite an extensive search in the

29 Varisco $1982: 257$. 
literature the present writer has indeed found that other field surveys yield little comparative information since very few of them record sufficient detail about the conditions surrounding different sharecropping systems to allow a comparative analysis to be made with his own findings. In particular, the literature would seem to be entirely silent on the subject of sharecropping animals, a practice which, though of less importance nowadays than formerly, still exists in the Yemen and a study of which is the subject of the next chapter, Chapter 7 .

Nevertheless, such field studies as do provide some information against which the present $\mathrm{f}$ indings can be assessed indicate the likelihood that the results detailed in the above analysis do reflect more generally applicable patterns to a large extent. For example, as was noted in the course of the analysis, the $1987 \mathrm{UN}$ report already referred to above found that most pump owners in Tihāmah take one-half the crop, leaving the remainder to be shared in different proportions by the landowner and the sharecropper ${ }^{\mathbf{3 0}}$, and a 1977 UK Overseas Development Administration report on Wādi Rimac in Central Tihämah arrived at the same finding $^{31}$. Again, in the Ibb and $\mathrm{Ta}^{\mathrm{c}} \mathrm{izz}$ area (the Southern Mountains region of the present survey), the UN report discovered that the share of the tenant on ghayl-irrigated land is one-half the crop, while on well-irrigated land in the same area his share is most usually also one-half the crop unless he owns the water pump in which case his share rises to two-thirds or three-quarters ${ }^{32}$. All these findings concord in general terms with the results of the present survey and validate its accuracy at least to a limited degree and in general terms.

Certain generally applicable observations can therefore perhaps be drawn. First, within any given region the share of a

\footnotetext{
30 UN $1987: 23$.

31 Makin (ed.) $1977: 57$.

32 UN $1987: 24$.
} 
sharecropper dependent on rain is likely to be higher than his neighbour who has access to a less risky source of water from a well or a ghayl. Second, a landowner who rents to a tenant only land and not water (the water being provided by the tenant from his own well or from rain, or else bought separately) will on the whole receive a smaller proportion of the crop than one who supplies water as we 11 as 1 and.

The question of why the dominant or preferred systems of cropsharing for the same crop and same water source vary between regions is however practically impossible to explain, given the present limited data. According to these data, it is, for example, specifically not the case, as might be postulated a priori, that sharecroppers dependent solely on rain on the Northern Plateaux and Central Plateaux, where rainfall is relatively low on average and is also highly variable from year to year, tend to receive a larger share of the crop than do sharecroppers in.the Southern Mountains where rainfall is relatively high and harvests therefore less risky than on the plateaux. Similarly, a sharecropper dependent on rain in one region does not necessarily take a larger share of the crop than a sharecropper using a less risky source of water in another region. To explain such inter-regional differences the researcher has no choice but fall back on the explanation the farmers themselves give: systems differ from place to place sālif al-balad and basab al-curf - that is, they are accounted for by differences in the established customs from one place to another. 


\section{CHAPTER 7 : SHARECROPPING ANIMALS IN THE YEMEN}

7.1 Introductory Remarks

7.2 The Yemeni Terminology of Sharecropping Animals

7.3 The Incidence of Sharecropping Animals in the Yemen 7.31 The Present Incidence and Rationale

7.32 Reasons for Recent Decline

7.4 Analysis of the Systems of Sharecropping Animals in the Yemen

7.41 Division of the Sale Price of the Original Animal

7.42 Division of the Produce

7.43 Division of the offspring

7.5 Comparison with Analogous Systems

7.51 Northwest Africa before the First World War, according to Milliot (1911)

7.52 Northern Tunisia in the $1930 \mathrm{~s}$, according to Noë 1 (1938)

Brief Excursus: "Transport Sharecropping"

7.6 Concluding Remarks on Sharecropping Animals 


\subsection{Introductory Re-arks}

The system of sharecropping domestic animals is the same in principle as sharecropping land: the owner makes over his property (in this case an animal rather than a plot of land) to another party to tend for a limited or unlimited period in return for part of the produce $^{1}$. As with sharecropping land, sharecropping animals may be viewed in either of two ways: (1) the owner hires the services of the second party, in which case the latter receives his wage as a proportion of the yield; or (2) the owner leases the usufruct to the second party, in which case the owner receives rent as a proportion of the yield. The system is quite distinct from the employment of paid shepherds or cattle-herdsmen on a fixed wage, in the same way that sharecropping land is distinct from the employment of paid agricultural labourers on a fixed wage.

The practice of sharecropping domestic animals, which are usually in the Yemen cows, sheep or goats, would seem to be one of the least studied aspects of Yemeni agriculture. Economically the practice is much less important today than it once was for reasons that will be given, but it is still significant especially in rural areas far from the main urban centres, as will be discussed in Section 7.3 below. The practice is known to exist or to have existed elsewhere in the Arab world, but with the exception of two mentions in more general studies of sharecropping by French colonial administrators in North Africa in the first half of the twentieth

1 It is recognised that the term "sharecropping animals" is not ideal, since the meaning of the word "crop" must be stretched somewhat to allow it to include the produce of animals. In French the term is usually métayage de l'élevage (literally, sharecropping for rearing) or société pour 7'élevage (partnership for rearing), both of which are acceptable. However, English seems to lack a proper term and "sharecropping animals" is used here faute de mieux. 
century ${ }^{2}$, it seems to have gone unremarked. Certainly Islamic jurisprudents give it no attention in their works of figh, in contrast to sharecropping land $\mathbf{3}^{\mathbf{3}}$.

In this present chapter the Yemeni terminology of sharecropping animals is first studied (Section 7.2), and then some remarks are made about the present incidence of the practice in the northern Yemen today (Section 7.3). The various sharing systems found are discussed in Section 7.4, and the chapter ends with a comparison with some available evidence on sharecropping animals from North Africa (Section 7.5). As in Chapter 6, most of the information discussed here derives from the field survey conducted by the present writer in 1992 and 1993, the methodology and coverage of which was described in Section 6.2 of the previous chapter.

\subsection{The Yemeni Terninology of Sharecropping Animals}

Several different terms are used in the Yemen to name the practice of sharecropping animals, different regions preferring different terms. All the respondents questioned readily understood the term sharäkah bi-al-mawash $\overline{7}$ (sharecropping with animals) when used by the present writer as a neutral, non-regional description of the practice, but it is clearly not the usual expression employed by the rural Yemenis themselves4. Instead, the terms used vary

2 Louis Milliot, who was to become one of the most prominent lawyers in the French colonial régime in North Africa in the interwar period, devotes a chapter to sharecropping animals in his doctoral thesis of 1911 on sharecropping in Morocco, Algeria and Tunisia (Milliot $1911: 63$ and 130-143). A short paper by Philippe Noël written just before the Second World War on sharecropping in northern Tunisia has a few pages on sharecropping animals (Noël 1938 :13-17). Both these studies will be reviewed below (Section 7.5).

3 Cf. Milliot 1911 :63: "Les auteurs [du droit musulman] ne font jamais de la société pour 1'élevage l'objet d'une étude spéciale".

4 However, it is interesting that Louis Milliot (1911 :130) quite independently referred to the practice in North Africa as "cherka fi-1-mawâch $\hat{\imath}^{\prime \prime}$ (that is, sharikah $f_{\overline{7}}$ al-mawash $\overline{7}$ in the transliteration used in this present thesis) which he translates into French as "société pour 7 'élevage". 
considerably from area to area, though all tend to be derived from one or other of the roots $r-b-w$ (growing up and upbringing), $r-c-y$ (grazing and tending), $r-b-c$ (containing the idea of "four-ness"), and $s h-t-r$ (dividing in half). Although links with the meanings of all these roots can clearly be perceived to some extent in the conditions of the system as it is practised in different areas (rearing and tending the animal and sharing by quarters or halves the produce, offspring and profit on sale), none of the usual lexical works, nor as far as can be seen any specialist Yemeni vocabulary list, records the terms with the same specific reference to sharecropping animals as they are employed in the Yemen at the present-days. As is the case with sharecropping land the terms for sharecropping animals are predominantly on the Form III verbal noun pattern mufácalah or sometimes $f j^{c} \bar{a} l / f j^{c} \bar{a} l a h$ or $f a^{c} \bar{a} l / f a^{c} \bar{a} l a h^{7}$, though derivations of the verbal patterns tafaccala and tafácala (verbal Forms V and VI) are also found.

In the Central Plateaux around Dhamār and Radāc at least, the most common and widely used names for the agreement are ribāc and murābacah. Either or both of these terms were found in Dhamār itself, at Afq (to the north of Dhamār), at al-Mayfacah (between Dhamār and Radāc), and around Radāc. A variant ribāc $\overline{7}$ was heard at al-Kahaylah (near $\operatorname{Rad}^{\mathrm{c}}$ ). In this region the sharecropper was once referred to as the mutaräbic.

In the Southern Mountains ribāc was heard also at al-cudayn, but more common by far in this region (including at Dhī al-Sufāl,

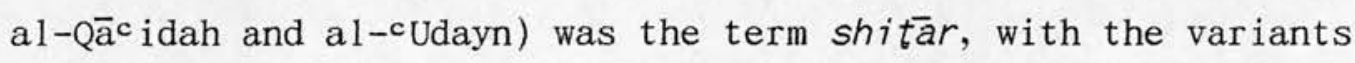
shatar and mushātarah also widespread. The sharecropper here was called shat̄ir and very occasionally (at al-cUdayn) mutarābic.

5 Wehr does give muräbic as a partner in an agricultural enterprise who shares one quarter of the gains or losses, though sharecropping animals is not specified.

6 Cf. muzāracah, etc.

7 Cf. sharākah. 
In the central part of the plain of Tihämah around al-Zacfarān and al-Abyāt (southeast of al-Hudaydah) the system was universally referred to as murābāh and the sharecropper is called murabbī. However, a hundred kilometres to the south of al-Hudaydah at al-Suwayq ( $12 \mathrm{miles}(20 \mathrm{~km})$ west of $\mathrm{Zabid})$ the only term recorded was mutaräbic for the sharecropper, as heard sometimes also on the Central Plateaux.

In the Sanc $\bar{a}$, area no general pattern of usage was found during the field survey, no doubt partly because the practice of sharecropping animals in the vicinity of the capital is now more or less extinct and partly because of the linguistic influence of incomers from other areas. In the village of Sanāc (some 6 miles $(10 \mathrm{~km})$ to the south-west of $\operatorname{san}^{c} \bar{a}$ ') the agreement was referred to as rabā' (presumably for riba') and the sharecropper as rabī, but at Shibām (some 25 miles $(40 \mathrm{~km}$ ) to the north-west of the capital) the preferred term was tiraccā (for $\operatorname{taracc}^{c} \overline{\text { ) }}$ and the sharecropper was mutaracc $\overline{7}$.

In addition to the above terms the terms shari $k, a \bar{j} r$ and musta'jir for the sharecropper in animals were also widely found, and the animal owner was everywhere referred to as mälik or sabjib al-mäshiyah or mälik / sābib al-mawāshī.

\subsection{The Incidence of Sharecropping Animals in the Yemen}

\subsection{The Present Incidence and Rationale}

During the present field survey some details of the practice of sharecropping animals were collected in all the areas visited. Respondents were generally agreed that its occurrence was more common $f_{7}$ ayyām al-Imām (in the time of the Imam) or qabl al-thawrah (before the republican revolution of 1962), or more generally $f_{7}$ a)-mā $\overline{7}$ (in the past), than it is now. In some areas indeed, and in particular in settlements close to Sanc $\bar{a}$ ' and other urban centres, the practice would seem to be virtually extinct, though even in these areas older respondents were able to provide particulars of how the system used to operate. Nevertheless, on the Central Plateaux (at al-Mayfacah, between Dhamār and Radāc), in the Southern Mountains (at al-cUdayn and Dhī al-Sufāl) and in Central Tihāmah (at 
al-Kimbāhiyah to the south-east of al-Hudaydah, and al-Suwayq west of $\mathrm{Zabid}$ ) the present survey included respondents who were actively involved in animal sharecropping, either as owners or as sharecroppers, and there can be no doubt that the practice is still alive in the Yemen, even if to a lesser extent than formerly.

The animals involved in the instances encountered during the field survey were always either cows or sheep/goats, though according to some respondents other domestic animals (donkeys, mules and camels) were said to be treated in the same way on occasions ${ }^{8}$. In one instance at al-Kimbāhiyah (Central Tihāmah) the respondent at the time of the field survey was sharecropping five cows and seven sheep/goats, and in another case in the same locality another respondent had four cows and 15 sheep. In all other field cases the number of animals involved was generally only one or two, and it may well be that the plain of Tihämah is exceptional in the extent to which animal sharecropping is still practised.

The system was generally described by respondents in the field survey on the following lines. One individual (called here the owner) decides to buy a young bull or bullock, a female calf, or a lamb or kid, and gives it to another individual (the sharecropper) to rear for him. The sharecropper provides fodder and shelter for the animal until it is fully grown and when it is sold he receives either a proportion of the sale price or else a proportion of the profit (that is, the difference between the buying price and the sale price). If the animal is female the sharecropper takes also a proportion of the offspring and benefits from the milk and milk products, either wholly or in part, after each birth. The owner receives similarly a proportion of the sale price and, in the case

8 Although it was not mentioned by any respondent, there would seem to be no reason why hens and other domestic fowl could not be sharecropped also. One possible case of bees being sharecropped was recorded at al-cUdayn (in the Southern Mountains), though the case is unfortunately unclear in its details since the conversation in which it occurred was prematurely broken off. Interestingly, as will be seen in Section 7.51 below, both bees and domestic fowl are (or at least were once) sharecropped in northwest Africa (Milliot $1911: 131)$. 
of a female animal, a share of the offspring and often also of the produce.

From the point of view of the owner, the advantage of the system is that he receives a return on the capital he originally invested in buying the animal in the first place (by receiving a share of its sale price and also, if it is a female, a share of the progeny and usually some of the milk products), but he remains free of the expense and inconvenience of rearing it. The sharecropper who bears the expense of rearing the animal also benefits from the sale of the animal and, if the animal is female, a share of the progeny and the milk products, without having usually to outlay an initial capital lump sum.

However, instances were noted at Mishrāfah in Wādī Rimàc (Central Tihāmah piedmont) of sharecroppers having the choice of providing one-quarter of the buying price, in which case their share of the selling price was also one-quarter, though if they contributed nothing to the buying price they received no share of the price on sale. This system found at Mishrāfah in which the sharecropper may contribute to buying the animal may be more widespread in the Yemen than the field information indicates, though generally speaking the most usual sharecropper of animals is one who has little capital, either in money or in land, as one might expect. This impression was somewhat substantiated by a relatively rich respondent in al-cUdayn (Southern Mountains) who, when he was asked whether he was a sharecropper in animals, said rather dismissively a7-shitār 7i-al-muwātinīn bidūn mazracah (sharecropping animals is for people who don't have a farm).

\subsection{Reasons for Recent Decline}

Several respondents in the field survey were asked why the system of sharecropping animals was now less common than in the past. One reason given by two respondents in al-Ahjur (Northern Mountains) was izdiyäd al-multak (the increase in owners), meaning that nowadays more people have greater wealth and can, if desired, afford their own animals, so that fewer people need to rely on tending other people's animals. Another respondent, at Shibām (Northern 
Mountains), said: $a \bar{l}-\not \bar{i} \bar{n}$ kill shakhs mālik (nowadays everyone is an owner). Such answers tend also to support the common sense impression mentioned in the previous paragraph that sharecropping animals is and was carried out mainly by the poorer sections of the population without capital.

Another reason, given by the head of the government agricultural office for the governorate of Dhamār, was kathrat a1-cadad a1-muhtarib min a7-qurā (the large number of people leaving the villages). Even though migration from rural to urban areas is undoubtedly a feature of the Yemen as other developing countries, the extent to which this is a valid reason for the decline in sharecropping animals is perhaps arguable since the country still has a very high rural population'. The real effect here may be indirect, since migration to towns of ten increases rural wealth through remittances when the links between urban workers and their home villages are maintained, as is generally the case in the Yemen.

But by far the most common explanation for the decline in animal sharecropping given by respondents in the present survey in all areas was that both fertiliser (samäd) and dairy products - samn (butter) and laban (buttermilk) - are now freely available in local markets without the need to raise animals and to prepare the products domestically. As one respondent at al-Ahjur (Northern Mountains) put it, al-b̄̄in mish Tazim yicallif, yiqaddib, wa-kidhā kill shì mutawaffir fi al-sūq (nowadays it's not necessary to provide fodder and cut it and so on; everything's freely available in the market).

9 As was mentioned in Chapter 1 (Section 1.3 above), the latest population census for the northern part of the Yemen (the former YAR) which has been obtainable was that taken in 1986. Although another census was planned for the united Yemen in January 1994 (as announced in The Yemen Times, 8 January 1993, p.2), the published results have not become available to the present writer. However, the 1986 census projected that by 1990 some $79 \%$ of the population of the northern part of the country ( 8.86 million out of 11.28 million) would still be rural (Yemen Republic 1991 :Table 2). 


\subsection{Analysis of the Systers of Sharecropping Animals in the Yenen}

The proportions of the sale price and of the offspring and milk products which form the sharecropper's share, and also other details of the sharecropping agreement, vary not only from area to area but also from one contract to another within the same area. The most common systems however are by halves and quarters, a fact reflected in the widespread use of derivations from the roots $r-b-c$ ("four-ness") and sh-t-r (halving) to specify the system and the parties to it, as was pointed out above (Section 7.2).

\subsection{Division of the Sale Price of the Original Animal}

In the large majority of cases found in the field survey, when the animal came to be sold the sharecropper and the owner would share the profit (the difference between the purchase price and the sale price) between them equally, the owner recovering in addition the purchase price he had originally paid. Thus, to use the figures of a hypothetical example quoted by one respondent who tended several sharecropped animals, if a young bull were bought for YR 4,000 and sold several years later for YR 16,000, the profit of YR 12,000 would be shared equally between the owner and the sharecropper so that each party got YR 6,000, and the owner would take also the YR 4,000 he originally invested 10 .

However, many agreements differed from this general pattern. In the area of al-Suwayq (Central Tihāmah) one instance was recorded of the sharecropper taking as much as two-thirds of the profit (YR 8,000 to use the figures of the above example). On the Central Plateaux instances were noted in which the sharecropper received by contrast only one-quarter of the profit (YR 3,000), while at al-Ahjur (Northern Mountains) it seems to be usual for him to take none of the selling price at a11. At Mishrāfah (Central Tihāmah

10 The figures in this example realistically reflected local prices in the middle of 1993 (when there were approximately YR 75 to the pound sterling on the free market), though at the time of writing (1998) prices would of course be considerably more as a result of the large inflation which the Yemen has undergone in the interim. 
piedmont) whether the sharecropper received a share of the profit depended on whether he contributed to the buying price, as has already been mentioned above (Section 7.3).

Other variations, which tend to raise the share due to the sharecropper, were also noted. In the case of female animals which were pregnant at the time of sale the sharecropper's share would be higher, the justification being that he has lost one of the offspring which would otherwise have been due to him had the pregnant animal not been sold. Similarly, his share would also be higher if a female animal is sold before it has given birth for the first time, since the sharecropper will not have benefitted at all from either offspring or milk or milk products. Such cases were recorded especially in Central Tihāmah. In one instance at al-Suwayq a quarter of the profit on sale would normally go to the sharecropper, though if the animal had never given birth he would take a quarter of the sale price, and so to use the figures in the above example, his share, normally YR 3,000 (i.e., one-quarter of the profit of YR 12,000), would rise to YR 4,000 (i.e., one-quarter of the sale price of YR 16,000).

In other cases, either the profit on sale or the total selling price would be divided not into halves or quarters but rather into a one-third share and a two-thirds share, and either of these shares could go to the owner or the sharecropper. This was so even in areas where the name of the practice is derived from the roots which imply halves and quarters $(s h-t-r$ and $r-b-c)$. In short, as many respondents in all areas replied, the proportion due to the sharecropper of the profit or of the sale price was basab al-ittifaq, that is, it depended entirely on the details of the agreement, and these could vary considerably.

\subsection{Division of the Produce}

The general rule in most areas would seem to be that when a female animal (whether a cow or a sheep or goat) gives birth, all the laban (buttermilk) and either three-quarters or one-half of the samn (butter) are the sharecropper's, though in one case (at Ribāt cImrān, Central Plateaux) his share of the samn was recorded as 
two-thirds. In these cases, the usual method of sharing the samn is for the owner to take it all every second, third or fourth week (depending on whether his share is respectively a half, a third or a quarter). However, in all cases noted in Central Tihāmah the sharecropper was able to take not only all the laban but all the samn also.

In addition, it is customary in some areas for the sharecropper to present the owner with a preparation made from the beest or beestings (that is, the first milk of a cow which has just given birth). This gift is called libá'11 and was noted on the Central Plateaux around Dhamār, in the Southern Mountains at Dhī al-Sufāl and elsewhere, and on the Central Tihāmah around al-Suwayq. The libā' is specially prepared and the method of preparation was described as follows by a respondent at Dhi al-Sufāl. The beestings are mixed with an egg and babb sawdā' (a kind of spice, perhaps that called "black sesame") and cooked until the mixture has thickened to form a cake. Another respondent, at al-Suwayq, said that in his area neither the egg nor the babb sawda' were added, but instead salt and pepper ( $f i l f i l$ ), and the milk was cooked in an abar (a kind of pot) until it had become thickened (mujammad) and formed a round flat cake (qurs). No doubt there are other regional variations in the libā' recipe. The giving of the libá' is not regarded apparently as part of the sharecropping contract strictly speaking but is said rather to depend on the goodwill of the sharecropper.

In addition to the laban and at least a share of the samn, the sharecropper is also entitled to all the manure from the animals he sharecrops. If the number of animals is large this can be a potentially very useful additional resource for him. Even if he has no land of his own and does not tenant someone else's, he can sell the manure to neighbours who do cultivate.

As far as other produce from the sharecropped animals is concerned, such as wool, hair and hides, little if any can be

11 Cf. Tibyah and 7ibāy, breast milk, quoted by Piamenta 1990-91 (entry root $7-b-y$ ), though Piamenta does not mention libä' itself. 
exploited by the sharecropper. Sheep and goats in the Yemen are raised primarily for their meat rather than the quality of their wool or hair, while the hides from them or from cows and bulls become the property of the butcher when they are sold for slaughter.

\subsection{Division of the offspring}

As with the division of the samn, the offspring of female animals are most usually shared by halves or quarters, though several variations were noted in the field survey.

Probably the most common and most straightforward system, which is found to some extent in all areas, is for the owner and the sharecropper to halve the offspring between them. This is generally done by each party taking ownership of alternate animals at birth, the sharecropper most usually taking the first newborn. Sometimes however it is the value of each animal which is divided equally between the two parties rather than sole ownership of alternate animals, while in two recorded cases (one on the Central Plateaux and the other in Central Tihāmah) the system was that the value of the first born would be divided equally but that subsequent births would be shared alternately.

On the other hand, at al-Ahjur (Northern Mountains), around Dhamār (Central Plateaux) and at al-Kimbābiyah (Central Tihāmah) cases were recorded in which the sharecropper received only a quarter of the offspring or a quarter of their value, and in one instance on the Central Plateaux (at Ribāt̨ c Imrān), a sharecropper took every third birth in the case of sheep and goats but only every fourth birth in the case of cows.

Clearly therefore generalisations on how the offspring are shared for even the selected field settlements are practically impossible to make, given the limited extent of the field survey material and the way in which the findings vary from contract to contract. Certainly no overall conclusions can be deduced which are applicable to the northern Yemen as a whole. On the other hand, sufficient evidence has been collected to show that sharecropping animals is still practised in the 1990s in the Yemen, and given the 
large literature on sharecropping land it is strange that the custom of sharecropping animals seems to have gone practically unremarked.

\subsection{Comparison with Analogous Systens}

Because of the silence of the Islamic jurists on the matter it is impossible to say what the official Islamic view of the practice of animal sharecropping might be. Presumably, if a question of its legality ever arose, then sharecropping land would be used as the qiyas (analogy). Further, it would seem that modern field studies of the practice are very rare, at least in Islamic countries, and comparisons of the Yemeni forms of the practice with those encountered elsewhere are consequently almost impossible to make. The sole references discovered which mention the practice are the studies referred to above in Section 7.1 by the French colonial administrators in northwest Africa in the first half of the twentieth century: Louis Milliot in 1911 whose work covers all three of the Maghrib countries (Morocco, Algeria and Tunisia); and Philippe Noël in 1938 who is concerned specifically with only northern Tunisia12.

\subsection{Northwest Africa before the First World War, according to} Milliot (1911)

Milliot's study of what he calls la société pour l'élevage as a translation for cherka fi-1-mawâchî (that is, sharikah fi al-mawāsh $\overline{7}$ in the transliteration of this thesis) forms one chapter of his analysis of sharecropping contracts in the Maghrib countries, which, as has been remarked, seems to have been the first detailed study of sharecropping in the Islamic context carried out by a western lawyer. He notes that Islamic authorities are silent on sharecropping animals and he speculates that it may never have been an important enough practice to warrant their attention. Nevertheless, he says, the system does meet very real economic needs.13 The strong impression is given indeed that the practice,

12 Milliot $1911: 63$ and 130-143; Noë1 $1938: 13-17$. 
at least in the early twentieth century, was not only widespread but thoroughly institutionalised in northwest Africa, and that, in the case of sheep, goats and cows at least, the numbers of animals subject to a contract would be much greater than is the situation in the Yemen at the present day ${ }^{\mathbf{4}}$.

According to Milliot, any kind of domestic animal (except of course pigs), and in addition fow 1 and bees, can be the subject of sharecropping contracts in northwest Africa, and whether the contract is written down or not depends largely on the custom of the district15. Unless the animals are camels or horses, the sharecropper would not normally be allowed to use them as draught animals (Milliot presumably has cows or bulls in mind here rather than sheep or goats) without the permission of the owner, in which case the sharecropper would have to pay the owner a fixed rent for the use of their services $\mathbf{1 6}$.

Milliot identifies two basic forms that the contract may take, depending on whether or not the sharecropper contributes to the capital outlay. Although a capital contribution from the sharecropper will alter the situation somewhat, and although, further, there are some regional variations, of which Milliot gives some details, the sharecropper would normally be entitled to the following share of the animal products:

- all the whey;

- all the cows' milk, though he must supply the animal owner with a quantity of butter proportional to the number of cows (the proportion being determined by custom);

\section{Milliot $1911: 130-131$.}

14 Although Milliot nowhere gives any indication of typical numbers of animals involved in a contract he does mention constantly troupeau.

15 Ibid. :131-132. As will be discussed in the next chapter of this thesis (Chapter 8, Section 8.31), whether contracts in the Yemen are recorded in written form or are merely verbal is also largely geographically determined.

16 Ibid. : $135-136$. 
- all the goats' milk;

- half the sheep's milk;

- $\quad$ all the manure.17

In addition, the sharecropper will benefit from a share of the offspring and of the profit on sale, though the size of these shares is variable18. However, normally a sharecropper can expect gradually to build up a herd or flock of his own ${ }^{\mathbf{1 9}}$.

\subsection{Northern Tunisia in the $1930 \mathrm{~s}$, according to Noë1 (1938)}

Noël's account of sharecropping animals in northern Tunisia is much shorter than Milliot's, but in the details of how the produce is shared between the two parties and other practical aspects it is at least as revealing. As with Milliot's account, the strong ' impression is given that the practice of sharecropping animals was much more standardised, and perhaps more institutionalised even, in northern Tunisia just before the Second World War than it is in the Yemen today.

Noël provides no Arabic term for the practice, which he calls simply métayage d'élevage (literally, the sharecropping of rearing). From the information that he does give however, it would seem that there existed professional herdsmen in northern Tunisia who earned their livelihood from tending flocks and herds on a sharecropping basis: Noël calls them "une caste de spécialistes respectés"20. Such a situation is different from that recorded in the present field survey in the Yemen where, as has been shown earlier in this current chapter, sharecropping animals is carried out on a smaller scale by individuals who will probably also be farmers rather than specialist herdsmen'21. A further difference from the situation in the Yemen is that in northern Tunisia there was in the herdsman's

\footnotetext{
17 Ibid. : 134.

18 Ibid. : 137.

19 Ibid. :140.

20 Noë1 $1938: 14$.
} 
wage both a fixed monetary element and a fixed quantity of produce per head of the flock or herd, and this could be said to dilute, so to speak, the sharecropping nature of the contract22.

Concerning the details of the sharing systems, Noël

distinguishes between the system for cattle and that for sheep and goats. For tending herds of cattle, the sharecropping herdsman would receive the following:

- 10 Francs per head per year;

- 1 waybah of "merlout" per head per year ${ }^{\mathbf{2 3}}$;

- half a cow hide per herd per year;

- the milk from the herd;

- "a large share" from the sales of the butter.

The first three elements are thus fixed elements of the wage, while only the last two elements belong to a truly sharecropping system. The size of the share of the proceeds from the butter sales is not specified: Noël simply says "une participation importante". It will be noted that, in contrast to the Yemeni situation, the northern Tunisian sharecropping cattle-herdsman had no right to any part of the sale price when the cattle are sold nor to the ownership of any of the offspring.

21 If there exists in the Yemen what could be called a class of professional herdsmen who earn their living by tending flocks and herds on a specifically sharecropping basis, as opposed to a fixed wage, they were not met with during the present field survey.

22 Ibid. :14. Milliot in contrast does not mention such an arrangement which includes a fixed element.

23 A waybah (recorded by Noël as "ouiba") is a well documented Islamic unit of capacity. W. Hinz (1955:52) gives its size in mediaeval Tunis as approximately 12.6 litres, though the present writer does not know whether this still applied in 1938. is presumably some sort of commodity, the term possibly deriving from an Arabic word (Noël encloses the word in quotation marks), though the present writer has not been able to identify it. Because it is measured by capacity it may well be some kind of grain (possibly wheat or cracked wheat?). 
For sheep and goats the wage accruing to the sharecropping shepherd or goatherd was larger, and this was justified, so Noël says, by the greater attention that a flock of sheep or a herd of goats requires compared with a herd of cattle. It would also include a share of the offspring. The shepherd of a flock or the goatherd of a herd would earn the following:

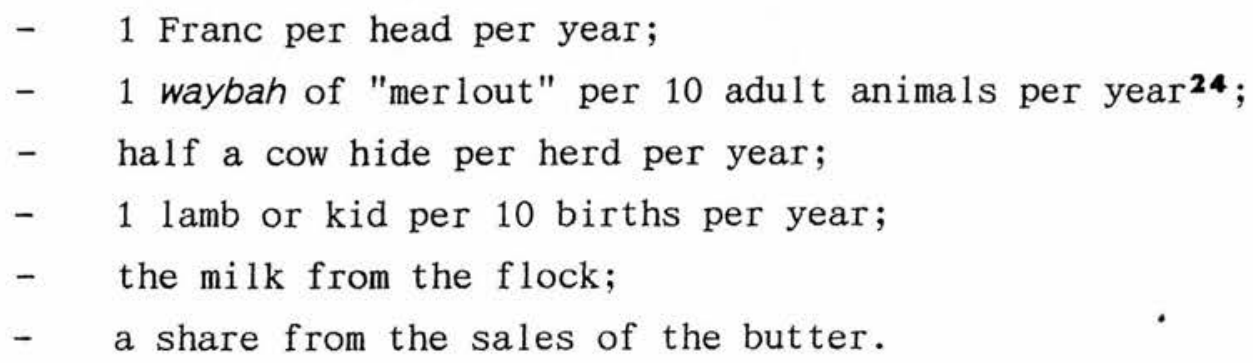

So here, the first three elements are fixed elements, while the last three are sharecropping proper. The inclusion of a share of the offspring in the herdsman's wage is significant, though at one-tenth of the births it is very much smaller proportion than the kind of share in the offspring taken by animal sharecroppers in the Yemen (usually one-half, sometimes one-quarter). On the other hand, because of the larger number of animals tended at one time in the Tunisian system, one-tenth of the offspring would no doubt produce a sizeable absolute number very rapidly, and indeed Noël says that by such appropriation sharecropping herdsmen can of ten quickly become owners of flocks in their own right 25 . Concerning the butter sales, Noël again does not specify the size of the herdsman's share.

Somewhat amusingly, Noël ends his account of the practice in northern Tunisia with a few paragraphs of practical advice on how to choose a good herdsman-sharecropper: he will be shod in esparto grass sandals (which will be a sign of frugality); he will have yellow teeth (since chewing tobacco will enable him to withstand the

24 For waybah and "merlout", see previous note.

25 Ibid. : 15 . 
worst gale); and his crook will be well polished (a sign of constant use).

\section{Brief Excursus: "Transport Sharecropping"}

There is one additional point of interest in Noël's article. He describes, albeit briefly, a further kind of sharecropping in northern Tunisia to which the present author has never found any reference elsewhere. It is what Noël calls métayage de charrois, which might be translated, albeit somewhat inelegantly, as "carting sharecropping" or "transport sharecropping"26. There are three "inputs" which are considered: first, the labour; second, the mule and its fodder; and third, the cart, the harness and their maintenance. The provision of one of these elements entitles the provider to one-third of whatever is produced from the transport of the goods. Thus, someone who owns a mule and a cart with its accoutrements (that is to say, two of the inputs) could hire a labourer to transport some goods. Whatever profit results from the exercise is then shared, the mule and cart owner receiving two-thirds and the labourer one-third. Noël points out that it is possible for three parties to be involved, each providing one of the three inputs and benefiting from one-third of the proceeds.

\subsection{Concluding Remarks on Sharecropping Animals}

The point has been made in this chapter that the rationale behind sharecropping animals is the same in principle as that behind sharecropping land: both involve the transfer of a piece of property from its owner to a sharecropper, with each party benefiting from shares in the product. It has also been demonstrated that sharecropping animals in the Yemen shows great variation in the way in which contracts are set up and how large is each party's share of the product, just as contracts for sharecropping land vary in the same respect, and these variations are parallelled by a large range of regional terms used to name the practice.

26 Noë1 1938 :13. 
It is unfortunate that little can be said about how general are the features of the practice as found in the Yemen or how specific they might be to the Yemen. The reason, remarked on more than once in the chapter, is the apparent rarity of comparative studies on sharecropping animals from other countries. The two available to the present writer, which are both from formerly French colonial North Africa, have be discussed in Section 7.5 above, and points of apparent contrast with the Yemeni situation have been made. These are, notably, that, according to Noël's account at least, the North African systems were only partly sharecropping properly speaking (in that fixed wage elements were also present), and that they would appear to have been more standardised and institutionalised, and also to involve larger numbers of animals at a time, than is currently the case in the Yemen.

Even more reticent on the subject are the Islamic lawyers. Accordingly, it is difficult to make any statement on the conditions required by a contract to sharecrop animals to make it valid under Islamic law. Presumably, any legal problem or dispute would in practice be resolved on the basis of qiyas (analogy) with sharecropping land.

Why Islamic figh is so silent on the subject can also only be guessed at. As was mentioned in Section 7.51 above, Milliot speculated that it may never have been an important enough practice to warrant the attention of Islamic lawyers. This may well be true, at least in part. But might it also be that Islamic lawyers have never recognised the practice as significant just because it is not mentioned by any bad7th? Whether this is so or not, the lack of bad7 ths on sharecropping animals does certainly suggest either that the practice was unknown in the Hijāz at the time of the Prophet (though this would seem unlikely to be the case), or else that it never caused any serious offence to religious sensibilities of the early Muslims, despite its similarity to sharecropping land, which of course was legally problematic, as was discussed in Part I of this thesis. At any event, the practice produced no disputes which the Prophet was asked to resolve, according to the badiths as they have come down to us. 
The subject of incidence of disputes between the parties in sharecropping contracts, together with the contractual context of duties and responsibilities, is the subject of the next chapter, and it will be indicated there, inter alia, that disputes in land sharecropping at least are probably less frequent in practice than the writers of figh might lead one to expect. 
CHAPTER $8:$ SHARECROPPING CONTRACTS AND CONTENTIONS

IN THE YEMENI CONTEXT

8.1 Introductory Remarks

8.2 Landlord and Sharecropper: the View from the Field

8.21 Duties and Services Required of the Tenant

8.22 Supply of Seed, Fertiliser and Other Agricultural Inputs

8.3 Sharecropping Contracts

8.31 Written and Oral Contracts

8.32 Three Contract Formats from Hadramawt

8.33 Three Written Contracts from al-cudayn

8.4 Sharecropping Contentions and Pleas

8.41 The Field Evidence

8.42 Three Plea Formats from Hadramawt

8.5 The Sharecropping Fatwās of Ibn $\mathrm{Ja}^{c}$ mān

8.51 The Manuscript and its Author

8.52 Observations on the Manuscript

8.53 The Structure and Content of the Fatwas

8.6 Concluding Remarks on Contracts and Contentions 
CHAPTER 8 : SHARECROPPING CONTRACTS AND CONTENTIONS

IN THE YEMENI CONTEXT

"The owner doesn't do anything at all; he just reclines content on his couch and takes his share at the end of the year."

Words of a Yemeni sharecropper at al-Waqash, above Jiblah (translated from colloquial Arabic).

"The services [the tenant] does in cultivating the land and. repairing - well, it's because it benefits both the landowner and the sharecropper."

$$
\begin{array}{r}
\text { Words of a Yemeni sharecropper at Sanāc, SW of Sanc̄ă, } \\
\text { (translated from colloquial Arabic). }
\end{array}
$$

\subsection{Introductory Renarks}

This chapter will bring together some at present rather widely dispersed information, both published and unpublished, to provide a picture of some aspects of the contractual relationship between the Yemeni landowner and sharecropper and to examine the problems and contentions (by which term disputes is meant) that may arise from this relationship. In Section 8.2 some preliminary reflections are made on the landlord-sharecropper relationship in the Yemen, with emphasis on the tenant's duties and how the seed and other agricultural inputs are to be supplied. Section 8.3 then examines some examples of Yemeni sharecropping contracts. In Section 8.4 the available evidence on sharecropping contentions and pleas is analysed, and then finally Section 8.5 discusses the six examples of sharecropping fatwās found in an unpublished collection of Yemeni fatwās dating from around 1000/1600. 


\subsection{Landlord and Sharecropper: the View froe the Field}

\subsection{Duties and services required of the tenant}

From the point of view of the landowner the primary duty of the tenant is to hand over to him at the end of the harvest the agreed share of the harvest. In order to do this the tenant is required in the case of grains and other sown crops to prepare and plough the soil and harvest the crop, and in the case of perennial crops such as fruit trees and $q \bar{a} t$ to keep the orchards weed-free and apply fertiliser to the trees and to gather the harvest. He is also responsible for regular irrigation of the crop unless of course the only water source is rainfall. The labour for these tasks is provided by himself and usually members of his family, and is sometimes supplemented by paid labour which he contracts.

Many respondents in the field survey specified other duties, though all can be construed as specific tasks within the above general responsibilities. In some regions.where fields are large, in particular on the plain of Tihämah and the high plateaux, the tenant will also be responsible for the cost of hiring a plough and one or two animals (bullocks, donkeys, mules, or occasionally a camel) to pull it if he does not own them himself, or else a tractor (barräthah) in areas where such is available. Elsewhere, in mountain areas where terraced plots are too small for ploughing, tilling and also other earth-moving work such as embanking water channels is done by spade (kurayk ${ }^{\mathbf{1}}$ ), shove1-scoop (magrafah ${ }^{2}$ ) and a kind of hooked digging pick (bignah in the Ibb area ${ }^{3}$ ).

1 From the Turkish körek, shovel.

2 For mijrafah; cf. Varisco (1982 :333) who records it as majrafi (in al-Ahjur).

3 For bijnah; cf. Serjeant (1988:150) who quotes the term as a mattock used to dig wells in the Fadli Sultanate, South Yemen. In the Ibb area (at least!) the use of the hijnah/hignah is by no means confined to digging wells but is used much more generally in agricultural tasks which involve moving soil, such as in forming the abaj $\bar{j} n$ (to be mentioned again below) around the bases of palm-trees. Cf. Piamenta (1990-91 :85a) who gives the Yemeni verb bagan yibgin as meaning to hoe. 
Where payment of the rent is to be in cash (naqdan) rather than in kind (caynan), the tenant will also usually be responsible for the costs of marketing the produce. Sharecroppers who pay in kind are generally expected to bear the cost of delivery to the landowner.

In the case of crops which need pollination, especially date-palms, the tenant will be also responsible for the talaing, the pollinating, which will ordinarily involve mash (stroking the female flowers with the male) and julbufah (the operation of tying the male spadix ( 7 iqāb) of the date-palm into the female florescence for several days $)^{4}$.

Frequently mentioned also among the duties of the tenant is tașTh al-budud and tastib al-judrän (the physical repair of the boundary walls and the terrace walls) and also hifz al-budud (the maintenance of the farm boundaries both in their physical fabric and against encroachment by neighbouring landowners). In irrigated areas the tenant also has the duty to clean out and keep in good repair the water channels ${ }^{5}$ and the cisterns ${ }^{6}$, and also the abāj $\overline{7} n$, the circular banked depressions around the bases of date-palms which retain irrigation water. This last term (abäj $\overline{7} n$ ) was never heard in the field but it exists in certain Arabic legal sources ${ }^{7}$. In addition, and especially in qāt and fruit tree plantations, it is

4 The term julbufah is an etymological mystery. It was heard only in Tihämah and appears not to be recorded in the usual lexical sources. The term tala $\overline{7} h$ on the other hand is the standard Arabic word for pollination ( $\mathrm{cf}$. liqāh, the male spadix), while mash (literally, wiping or stroking) is widely used, at least in the Yemen, for artificial pollination.

$s$ There are several words for water channel or irrigation channel in use in the Yemen. As well as ghayl (p1. ghuyü 7 ) and sayl (p1. suyü7) for specific types of watercourse, the following are all

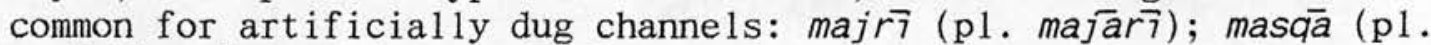
masāq $\overline{7})$; sāqiyah ( $\mathrm{pl}$. sawāq $\overline{7}$ ); or often nahr (lit. river, pl. anhär).

6 Probably the three most common words for cistern or reservoir in

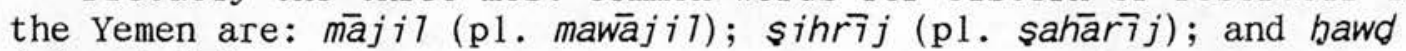
(p1. abwād). 
also the tenant's duty to protect the crop from night robbers, either by acting himself as watchman (bäris) or by employing one, for which purpose are the many two-storey towers which dot the $q \bar{a} t$ plantations of the mountain areas. In some regions, especially where the crop is dates, the tenant will be expected also to protect the fruit from scavenging birds and other animals 8

Al1 these duties were mentioned by respondents in the present field survey. One respondent (in Qābil Wādi Zahr, to the north of Sanca',) summarised them as camal al-zirācah min kull al-jawanib (the work of cultivating in all respects). It is rare for a landowner to extend to the tenant any help in them. As another respondent (at al-Waqash above Jiblah) put it, a l-mälik mā yisawwi ayy shay, yaglis murtāh caTa kursī-h, wa-yäkhudh bissat-uh $\bar{f}$ awakhir a 7-sanah (the owner doesn't do anything at all; he just reclines content on his couch and takes his share at the end of the year), a statement which may illustrate a certain degree of dissatisfaction with contractual arrangements felt by some tenants.

On the other hand, such discontent is probably only a minority feeling. Many Yemenis involved in sharecropping experience the practice from both sides, so to speak, since they are both

7 The term ahājin may well be a specifically Yemeni word since it does not appear in the usual lexical sources. The term is obviously connected with the digging tool bijnah cited in the text above. As was mentioned in Chapter 4 (Section 4.32 above), abāj $\overline{7} n$ is found in al-Nawawi Minhāj al-Tălibīn $(: 148$, where it has been wrongly edited by Van Den Berg as ajaj $\overline{7} n$ and is somewhat misleadingly translated into French as réservoirs). It is also found in two texts to be studied later in this chapter: the Hadrami sharecropping contracts in Section 8.33; and in Section 8.5 the Ibn $\mathrm{Ja}^{c}$ mān Fatäwa $\left(: 179 b_{20-21} \& 180 a s\right.$ where the author of the Ms. adds a clear gloss on the term as a 7-bafr bawl a 1-nakh7, the depression around the base of the date-palm, which must dispel any doubt as to its meaning).

8 In Hadramawt Serjeant has reported that a basket cover called a khubrah is placed over ripening dates to protect them from the depredations of birds, insects and animals (1967:62 n.110). The present writer noted that dates in Tihämah are protected in a similar way by being covered with sacking or other cloth, though unfortunately no further details of the practice, terminological or otherwise, were collected. 
landowners and sharecroppers, as was noted in Chapter 7 (Section 7.41), and they must as a result have a first-hand awareness of the requirements and difficulties of both standpoints. Moreover, as was pointed out in a more general context in Chapter 2 (Section 2.24) many of the contractual conditions, such as keeping the terrace walls and water channels in good repair, and irrigating the crops and protecting them from robbers, are in the interests as much of the tenant as the landowner since the size of the income of both parties depends on the size of the harvest. This was acknowledged by many respondents. As one respondent (in the village of Sanāc, to the southwest of $\mathrm{San}^{\mathrm{c}} \overline{\mathrm{a}}$ ') put it, al-khidmāt an yizrac a1-ard wa-yisallib - yacnī, caTa al-asās an yastafìd al-mālik wa-al-sharīk (the services [the tenant] does in cultivating the land and repairing - well, it's because it benefits both the landowner and the sharecropper).

The extent to which it is usual for the sharecropper to deposit with the landowner a shaq7yah (guaranty) which is necessary before he can begin working land on which there are perennial crops but which is returnable when he vacates the land, was not investigated in detail during the survey. In her study of Wâdi Zahr M.W. Mundy shows that the practice existed in her field study area in the 1970s for certain land but owing to the greater cash income from the increase in qāt growing both the payment of shaq̄yah and indeed the practice of sharecropping itself had become less extensive than previous $1 y^{9}$. Wādi Zahr, because of its proximity to Sancā' (it lies only some $7 \frac{1}{2}$ miles $(12 \mathrm{~km})$ north of the capital), may however be atypical in this, though to what degree it is impossible to estimate.

It is also very difficult to say how widespread or onerous on Yemeni sharecroppers are extra-contractual duties and services such as A.K.S. Lambton found in Iran10, E. Pratt in Italy11 and other researchers elsewhere, as was discussed in Chapter 2 (Section 2.23).

9 Mundy 1981 :62-64.

$10 \quad$ Lambton $1969: 330$. 
The reason for this is that the exact perimeter of the terms of the contract is difficult to determine. As will be seen below in Section 8.32 when three modern contracts from al-cudayn are examined, even a "service" such as giving the landowner "gifts" of the crop over and above his proper share when he visits the farm, which is normally taken to be extra-contractual elsewhere, is specifically mentioned within one of the al-cUdayn contracts as part of the agreement. The difficulty in deciding what is contractual and what is extra-contractual is increased by the appearance in contracts, such as those of al-cudayn, of catch-all requirements such as that the sharecropper is expected to do everything which is required of him sälif al-balad (according to the precedence of the place) or basab a $7-$ curf (according to custom). If it is the custom of the village that sharecroppers provide their landlords with extra gifts or carry out services additional to the work involved in producing a crop, such as building work or. road improvement, then these can presumably be deemed to be part of the contract and a sharecropper would have no grounds for complaint by claiming that having to provide such services lay outwith the contract. This would seem to be so despite the fact that Islamic jurisprudents, including the Zaydi Ibn al-Murtadā as was seen in Chapter 5 (Section 5.2 above $^{12}$ ), have ruled against the sharecropper having to provide services that are not directly part of the crop-producing process.

\subsection{Supply of seed, fertiliser and other agricultural inputs}

In the large majority of instances recorded in the field survey both seed and fertiliser and all costs of tilling and harvesting were supplied by the tenant, though in many cases this can be done at little monetary cost to him since seed is generally kept back from the previous harvest while manure is of ten available from his own animals or those of his neighbours. Chemical fertiliser (samad kimäwi) is used, but to a lesser extent than animal manure (samad

\footnotetext{
$11 \quad$ Pratt $1994: 41$.

12 Ibn al-Murtad̄a a7-Babr al-Zakhkhār :672-4.
} 
balad7), especially in areas distant from towns. In the case of rain-fed land fertiliser of any kind is seldom applied, except from the animals grazing the stubble.

Only in a minority of cases (approximately 20\%) were either the seed or the fertiliser or both supplied by the landowner, though the practice varies from contract to contract and some special and complex arrangements were noted. Consequently generalisations are difficult to make, though it seems clear that whether a landowner contributes depends on the custom of the area, since in many of the areas visited no instance of contribution by landowners was found while in other areas the custom by which the landowner contributed seemed relatively common. In one case (at Najr, south of cAmrān) the landowner supplied one-third of the cost of the fertiliser and one-third of the cost of the harvesting if he took his share of the sorghum before it had ripened to be used as fodder, though otherwise the tenant provided all inputs. In another case (also at Najr) the landowner paid the cost of the seed (but not the fertiliser) in proportion to his share of the harvest (in this case one-half), and a similar arrangement was noted in the Hamdān area to the northwest of Sanca', Other cases in the area of al-Suwayq (to the west of Zabīd in the Central Tihāmah) indicated considerable flexibility in whether the landowner supplied anything but the land: whether he contributed to other expenses or not depended entirely on what was agreed by the parties to the contract. In two cases at al-Suwayq the landowner's share of the crop was the same as his share of the cost of the seeds and fertiliser, and this share varied with the type of crop. In another case at a1-Suwayq the costs of the inputs for vegetables were shared between the sharecropper and the owner of the water pump, and if the landowner decided to help in supplying fertiliser he would take one-quarter of the crop but if not then his share would be only one-sixth.

Generally speaking however, in most areas the response was that kull al-mas̄ärīf min cind al-musta'jir or kull al-takāīf cata al-sharik (all the costs are on the tenant/sharecropper) or else al-mālik mā yadfac shay (the landowner doesn't pay for anything). This was so even if the tenant paid only indirectly. One landowner 
at al-Q $\bar{a}^{c}$ idah (between $\mathrm{Ibb}$ and $\mathrm{Ta}^{\mathrm{c}} \mathrm{izz}$ ), for example, reported that he supplied seed potatoes to his sharecroppers from his own pocket, but further questioning revealed that he recouped the cost min rās a 7-mabșü (from the harvested crop before it was shared out between him and his tenants), an arrangement which was subsequently confirmed in an interview with one of his sharecroppers. In most other instances where the landowner paid initially for the seed and the fertiliser it was found that he was recompensed by a larger share of the harvest than he might otherwise receive. This was the case with a landowner interviewed at al-Mukaymaniyah (south east of al-Hudaydah on the coastal plain of Tihāmah) who provided all agricultural inputs for his sharecropper (seed, fertiliser, and also the hire of ploughs and the costs of harvesting and marketing the produce) but took four-fifths of the harvest, which, as has been seen in Chapter 7 (Section 7.5) above, is a large proportion. The same proportion of the harvest was taken by landowners at Mishräfah (just above the point at which Wâdi Rimac debouches onto the plain of Tihāmah), though here again they supplied all agricultural inputs (including ploughing, harvesting and marketing) to their tenants.

In general therefore it would seem that in most areas in northern Yemen it is the tenants who supply all agricultural inputs but that in certain areas (including the Northern Plateaux and parts of Central Tihāmah) it is customary for the landowner to provide them, either wholly or in part, in which case the landowner's recompense is larger than it would otherwise be.

\subsection{Sharecropping Contracts}

\subsection{Written and oral contracts}

In theory, any contract may be recorded as a written document, though in Islamic law a verbal agreement before two witnesses is sufficient for the contract to be binding and in fact takes precedence over any written evidence ${ }^{13}$. It has already been

13 Cf. Imber (1997:26) who notes the same verbal nature of an example of the form for a marriage contract from a work of around $400 / 1000$. 
observed in Chapter 5 above that Islamic jurisprudents of ten state the proper form of words which will conclude a contract. Thus for example, as was shown in Chapter 5 (Section 5.2 above), Ibn al-Murtad̄a states that to make a mughärasah contract the following forms of words are valid:

The form [of words to make a mughärasah contract is for the landowner to say:] "Ghärastu-ka" (I engage you as a mughärasah tenant); or: "cAmaltu-ka" (I make a deal with you [under a mughärasah contract]); or "Ighris hädhihi" (Tend this [piece of land] under the terms of the mugharasah). It is on this [basis] with the agreement [of the engaged party] [that a mughärasah contract would be valid], or some [wording] to the same effect.14

For the musāqāh, Ibn al-Murtad̄a says the following:

[The correct form to make] a verbal musāqāh contract is [for the landowner] to say: "Saqaytu-ka cata hädhä a 1-nakhīl muddata ka-dhä" (I engage you in a musāqāh contract over these date-palms for such-and-such a period), or words to the same effect such as "Tacahhad $\pi 7$ hädhihi al-ashjār bi-al-saqy wa-à7-ișTah muddata ka-dhä" (Tend these trees for me by watering and maintaining them for such-and-such a period).15

Similarly, it was indicated in Chapter 4 (Section 4.32) that al-Nawawī also included forms of words to make a musāqāh contract.

In fact, they are very similar to those of Ibn al-Murtadā:

The correct form [of words to make a musāqāh contract] is [for the landowner to say]: "Saqaytu-ka caTa hädha al-nakhl bi-ka-dhä" (I engage you in a musāqāh contract over these date-palms in such-and-such a way); or else: "Sallamtu-hu ilay-ka li-tatacahhada-hu" (I hand [the date-palms] over to you so that you might take care of them). Then [the camil] has to show his acceptance, without all the details of the work involved [having necessarily been named]. What is not specified in any respect is to be referred to al-curf al-ghälib (the dominant custom).16

\footnotetext{
14 Ibn al-Murtad̄a, a1-Babr al-Zakhkhār, :677-8.

is Ibid., :69s-6.

16 Al-Nawawī Minhāj al-Tălibīn :II, 1472-5.
} 
All these examples - both the Zaydi and the Shāfic $\bar{i}$ - show that the emphasis is on verbal form: that is to say, the actual words spoken, and these need constitute only a brief sentence. If the correct words are spoken in a valid situation (where there are two witnesses, where both parties are of sound mind, and so on) then the contract will be binding. There is no stipulation that the contract be written down, nor even that all the conditions of the contract be verbally rehearsed.

In the Yemen, whether the contract between landowner and tenant is committed to writing depends very much on the custom of the area. In the Northern and Central Plateaux and in Tihāmah written land tenancy contracts (and indeed any kind of contract) are exceptional. The usual contract in these regions is verbal and bi-al-amänah or bi-a 1-thiqah (on trust) before two witnesses. Contracts were said to be written in these regions only under certain circumstances. One respondent at Ribāt c Imrān (between Yarīm and Dhamār) said that contracts in his area were sometimes written in the case of $q \bar{a} t$ and fruit trees because al-mabsül qawi (1it., the yield is strong, meaning that the harvest from such crops is worth a lot of money) but not in the case of grains. According to another respondent at al-Mayfacah (between Dhamār and Radāc) contracts were only written where the tenant was from outside the village and unknown personally to the landowner. A further respondent at al-Kahaylah (just to the south of $\operatorname{Rada\overline {c}}$ ) said the contract could be written if both parties wanted it written, but that this was rarely done since there were never any disputes between landowner and tenant in his area. If contracts are recorded in writing in these regions, then according to respondents in the present field survey anyone (ayy wahid) who can write can do the recording, and not necessarily a local government official.

In the mountain regions (Northern Mountains and Southern Mountains) on the other hand, all respondents indicated that land tenancy contracts were always written, signed by two witnesses and registered by a local or regional government appointed recorder who would be the amīn al-maball or ma'mūn al-cuzlah (the "secretary" or recorder of the village or 'cuzlah) or the bäkim al-nähiyah or nä'ib 
a7-häkim (the official qāoj of the nāhiyah or his deputy) who would provide it with an official stamp (khätam). One copy of the agreement would be given to each of the contracting parties and generally a copy would be retained by the recorder. Three examples of such contracts (from al-cudayn, in the Southern Mountains west of Ibb) will be considered in Section 8.33 below. First, however, the following subsection will examine an example of what might be called ideal or theoretical "proformas" for the three main kinds of sharecropping contracts against which it will be possible to compare the al-cUdayn examples.

\subsection{Three contract formats from Hadramawt}

In a lengthy paper on irrigation in Hadramawt R.B. Serjeant* quotes the text of three sharecropping contracts from a late nineteenth century Shāfici document from Hadramawt which for convenience may be called the Bā Sawdān Ms.17 The three contracts are respectively for musāqāh, mughārasah (though different terms are used here for mughärasah as will be seen) and muzäracah. They are evidently what might be called models or proformas, with words such as FuTan (So-and-so) and ka-dhā (such-and-such) in places where names and other information would be inserted. The re-edited text has been included in Appendix 3 of this thesis, and the following is the present writer's translation.

\section{(1) Form for the Musāqāh}

[The Shaykh] writes: Praise be to God.

So-and-so has engaged So-and-so in a musāqāh contract over stated date-palms in such-and-such a way, according to the legitimate rules of the musāqāh, for a period of one complete year, starting in such-and-such a month, for a share of half the fruit. [The tenant] will be responsible for tending the stated date-palms and pollinating them, and cleaning out the water channels serving them $\mathbf{1 8}$, maintaining the abajīn (the irrigation hollows round the base of the

17 The title of the document is Tahş $\overline{7}$ al-magșud fi-mä tuliba min tacrif al-cuquid, composed in 1315/1897. The paper of Serjeant's referred to here is Serjeant 1964 and the contracts are quoted on pp. 61-62 of it. The present writer has not examined the original document and is reliant on Serjeant's published extract. 
date-palm trunks)19, removing grass [and weeds], and guarding, harvesting and drying the fruit. [The tenant] may do all this either by himself or by someone he delegates to do it.

(2) Form for the Mukhäbarah and Mufäkhadhah ${ }^{20}$

[Explanatory preamble:] This is also called the munasabah. It occurs when [the landowner] hands over the piece of land to someone who will plant it with trees. The trees may be shared between the two parties equally or unequally.

[The Shaykh] writes: Praise be to God.

So-and-so and So-and-so have agreed that So-and-so 21 should plant a certain area, or the land belonging to So-and-so, and then he should specify the number $\mathbf{2 n}^{2}$ of the kind of date-palms he wishes to plant. The young date-palms and the gear will be the responsibility of the tenant $\mathbf{2 3}$ and also he must irrigate and rear [the palms] until they mature ${ }^{\mathbf{2 4}}$, according to the custom (curf) of the district.

This [constitutes what is known as] fakhdh al-nisf aw cata munassafah (sharecropping by halves according to the mufakhadhah - i.e., the mugharasah) on the basis of which the two [parties] enter into a mukhäbarah and mufakhadhah agreement legitimately drawn up.

[The contract should end:] This is dated such-and-such a day, such-and-such a year.

18 The Arabic reads tanqiyat nahri-hi. Serjeant glosses this as "clean[ing] the trunks", which must be a mistake. Nahr (lit. river) is a common enough term for irrigation channel whether natural or artificial.

19 This term has already been discussed above (Section 8.21 and note 5). In Serjeant's text it has been wrongly written ajājīn.

20 It is clear from what follows that this format concerns the mughärasah contract. The terms mufakhadhah and munassabah are noted also by the author of the Bā Kathïr Ms. who says they both mean mughärasah (Bā Kathīr Ms. :1111-14 \& 1120-121). See also these three entries in Appendix 1 of this thesis.

21 Presumably the same as the second of the names just given.

22 The term bufrah ( $\mathrm{pl}$. bufar) is a Yemeni counting term - cf. the Omani qörah for counting trees and large plants. For Omani counting terms with some reference to the Yemen see Donaldson 1994.

23 The term used here for tenant is fakhīdh, deriving obviously from fakhdh and mufakhadhah. 
(3) Form for the Muzäracah and the Mukhäbarah when the land belongs to the party who sows it 25 [The Shaykh] writes: Praise be to God.

So-and-so has said to So-and-so: "Zaractu-ka (I have engaged you in a muzäracah contract) on such-and-such a plot of land - and [the owner] should here describe it - in order for you to sow it. I shall have the responsibility of supplying the seed-corn, and you will be responsible for [giving me] half the produce [from the land]".

Alternatively, [the landowner could say]: "cAmaltu-ka (I have engaged you in a contract) on such-and-such a plot of land. You will be responsible for providing the seed-corn and you will get half the produce [of the land], under the terms of a mukhäbarah or muzäracah contract clearly and legitimately set up and incorporating the conditions necessary to make it comply with correct legal form".

This is dated such-and-such a day, such-and-such a year.

Superficially these three model contracts may appear vêry similar. In all three the name of each party is to be specified, the plot of land is to be delimited, and a half share of the produce for each party is mentioned (though it may.well be that this proportion is given only as an example and would in practice vary,

24 The wording of this passage in the text is:

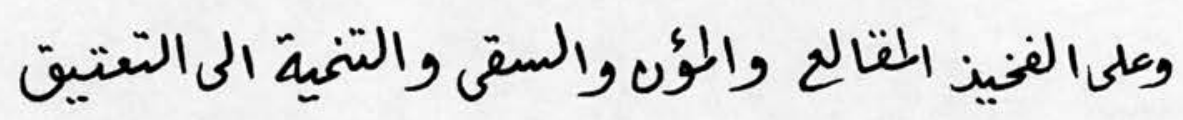

wa-caTa a 7-fakhīdh a 7-maqālic wa-a 7-mu'an wa-al-saqy wa-a 7-tanmiyah iTa al-tactī which Serjeant glosses as "Inter alia the working partner has to deal with the young palms (maqlac), irrigate them, and rear them up to the $\operatorname{tac}^{c} t \bar{i} q^{\prime \prime}$. He says that the term tactīa is unknown to him and he makes no suggestion for its meaning, but it would seem clear to the present author that, given the root and the context, it must mean maturity - that is to say, the date-palms must be looked after until the time they are old enough to bear fruit. The term mu'an Serjeant says means "gear", according to a Hadrami informant (Serjeant $1964: 62$ ). This is no doubt correct, and the gear would presumably include tools for digging, pruning, pollinating and so on, and materials for covering ripening fruit to protect it from pests.

25 It is not entirely clear what this means. As the text of the contract makes clear, the party who supplies the seed may be either the landowner or the tenant. But if the landowner also does the sowing himself then there would be no need for a tenant and therefore no contract! Unfortunately, Serjeant provides no gloss on the wording of this contract. 
if only because of the fact that the provision of the seed or plants can vary widely both between and within the contracts). On closer examination however, and with the benefit of background information such as has been put forward already in this thesis, certain differences between them which may be significant can be identified.

First, there is probably an implied difference in the relationship between the two parties in the different contracts which is reflected in the wording. In the first (musāqāh) and third (muzäracah) contracts the landowner is clearly the party who is taking the initiative while the tenant can perhaps be understood as being in a more subservient role: the wording of the relevant passage is qad sāqā fuTanun fuTanan in the first; qad qāla fuTanun 1i-fuTanin: zäractu-ka in the third. In both cases the landowner is engaging the tenant. However, in the second contract, which concerns the mughärasah, the equivalent wording is qad ittafaqa fuTanun wa-fuTanun: "So-and-so and So-and-so have agreed together". The implication is almost certainly that the landowner and the tenant in the mughärasah hold positions closer to equal partners, since, as will be remembered from Part I of this thesis, the tenant's contribution to the partnership can be more substantial in the mughārasah than in the other two types of sharecropping contract.

Second, there can be clear differences in the matter of which party supplies the seed or plants. In the case of the second (mughärasah) contract, it is explicitly stated that the trees to be planted may be supplied by both parties either equally or unequally (bi-a7-sawiyah aw a7-tafoj7). In the third (muzäracah) contract it is again explicitly declared that either the landowner or the tenant may supply the seed. In the first (musāqāh) contract however, neither party is mentioned as owning the trees, though it may be assumed that they belong to the owner of the land.

Third, in the first two contracts (musāqāh and mughärasah), the duties of the tenant are spelt out in some detail and concern in both cases principally looking after the trees and the irrigation channels on which they depend. In the third (muzāracah) only the sowing of the seed is mentioned. 
In connection with the duties of the tenant, in the case of the mughärasah contract there occurs the phrase bi-curf a 1-jihah (according to the custom of the district), though it is considered unlikely that there is any significance in the absence of a similar reference in the other two contracts, since it may be presumed that, as with the Yemen Civil Code sharecropping Articles discussed in Chapter 3 (Section 3.5 above), where specific conditions are not stated local curf will take precedence. After all, as they stand, these "model contracts" are hardly more than the bare bones of what a legally binding agreement would have to cover. Many - perhaps even most - of the conditions which could conceivably lead to dispute are simply not mentioned at all. Which party, for example, has the responsibility of covering the transport of the landowner's share of the crop? Does the tenant have to do this, or will the landowner collect it himself? Again, which party is responsible for the costs of upkeep of boundary walls, wells, terraces, and other fixed installations? For example, cleaning out the water channels is clearly the tenant's responsibility, and indeed is stated as such in the musāqāh and mughārasah contracts. But where does "cleaning out" stop and "rebuilding" begin? Such questions are not answered by these model contracts and it may be presumed that any dispute involving them would be referred to curf al-jihah, the custom of the district.

In the third of the contract models (that concerning the muzāracah) it is notable that the form it is couched in is explicitly verbal, and even the other two could be construed as being models of verbal contracts since there is no mention of any need to record them in writing. If this is so, then the reference at the end of the second and third contracts to recording the date of the contract could be understood as referring to a written record to be kept merely as a kind of aide mémoire kept by either or both of the two parties and possibly also one or more of the witnesses. This impression of the essentially verbal nature of such contracts (whether or not they are also committed to writing) will be strengthened in the study now of three modern Yemeni sharecropping contracts. 


\subsection{Three written contracts from al-c Udayn}

In the course of his field survey the present writer had the opportunity to examine several documents in the possession of farmers which recorded their sharecropping contracts with

landowners. All these were in the areas where it is the custom to record such contracts in writing (that is, the Northern and Southern Mountains), but with the exception of al-c Udayn in Wādi ${ }^{c}$ Annah (west of $\mathrm{Ibb})$ all were seen in isolated areas without means of photocopying. At al-cUdayn however the aminn a7-mabal7 was able to provide a photocopy of his record of three example contracts of sharecropping. All are dated Muharram 1407 (which began on 6th September 1986). A copy of the original documents is included in Appendix 3 together with a transcription and notes, and a sketch map of at least some of the locations mentioned is given in Figure 8.1. The following is the present writer's own translation ${ }^{\mathbf{2 6}}$. (The term aj $\overline{7} r$ (tenant) has been left untranslated.).

\section{Document No.1}

In the name of God the Merciful, the Compassionate. ${ }^{c}$ Abdallāh Muhammad cAqīl [from the ${ }^{c} u z l a h$ of] Banì Zuhayr, [1iving at] the group of houses [called] al-Sharq $\bar{i}$ and being of sound mind and in complete concurrence with the law, came to us to [become] an ajīr of Shaykh cAbd al-Qawi bn Mulhī and his

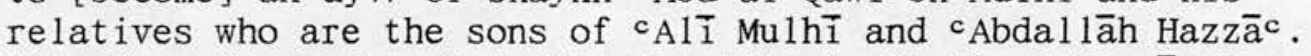
[The farm in question] is the locality [called] al-Rummanah which is bounded on the north by the bed of the Wadi [cAnnah] and on the west by al-Khurayshabah, and above which is the property of the above mentioned people worked by the $a j \overline{7} r$ Murshid Mulayk. [This contract was drawn up] in the presence of witnesses who are ${ }^{c}$ Abduh Muhammad Murshid [from] the town [i.e., al-cUdayn] and Hazzāa Mahdi [from the cuzlah of] Jabal Babri, though God is the best Witness. [This contract] was drawn up in the month of Mubarram in the year 1407 one-thousand

26 I am very grateful to $M r{ }^{c}$ Abdallāh ${ }^{c}$ Abduh ${ }^{c}$ Abdallāh, the $A m \overline{7} n$ of al-cudayn, for allowing me to photocopy these three contracts, and especially to Mr Jābir Muqbil cAbd al-Mālik, the director of the Agricultural office, al-cudayn, for devoting considerable time to help me understand them. A glance at the original Arabic in Appendix 3 of this thesis will show that their short-hand nature requires considerable interpolation to be made which is impossible without an intimate knowledge of the local area. 


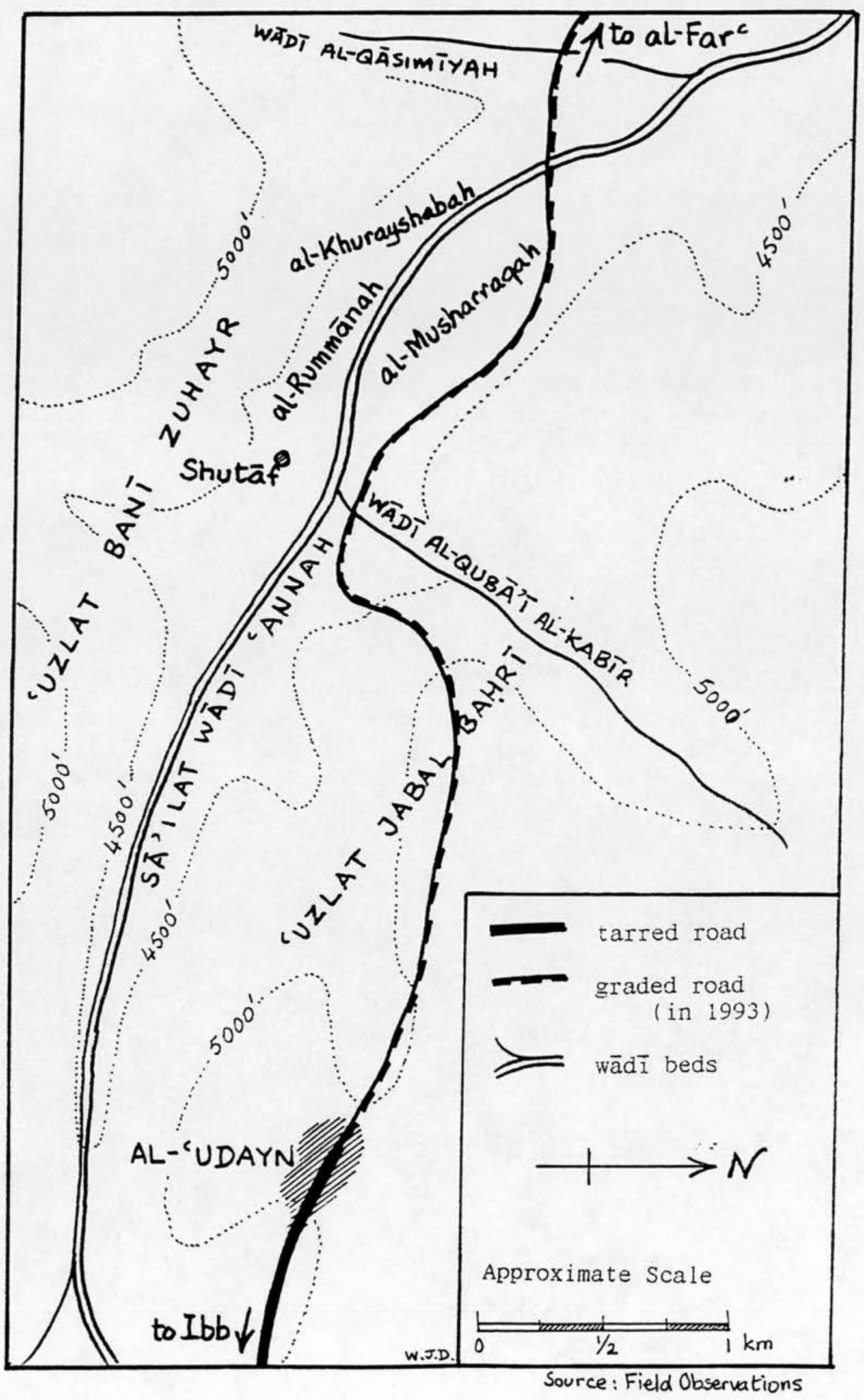


four-hundred and seven after the Hijrah of the Prophet, may the most excellent blessing and peace be upon him. The said aj $\overline{7} r$ is an $a \sqrt{7} r$ who is not a [land]owner. [The responsibility will be] on him to deliver the landowner's share of the harvest to the place [where it is to be] handed over, to maintain the boundaries [of the property] and to give [the landowner] gifts from the crops [when he visits the farm, in accordance with] the precedent of the place. ...

\section{Document No.2}

In the name of God the Merciful, the Compassionate. Hazzāc Mahdī Qāsim [from] the cuzlah of Jabal Babrī, being of sound mind, came to us to [become] an aj $\overline{7} r$ of Shaykh ${ }^{\mathrm{c}} \mathrm{Abd}$ al-Qaw $\bar{i}$ bn Mulhī. [The farm in question] is the locality [called] al-Qubä'i al-Saghīr, [is] totally irrigated, and is bounded on the north by the bed of the Wadi [cAnnah], on the west by the Wadi al-Musharraqah, on the south by [the place called] Shutāf, and on the east by [the Wädī] al-Qubā' $\bar{i}$ al-Kabir. The said person is an aj $r$ who is not a [land]owner. [The responsiblity will be] on him to deliver the landowner's share of the harvest to the place [where it is to be] handed over, to maintain the boundaries with the boundaries [of neighbouring properties], and [to carry out] what aj7rs must do [in accordance with] the precedent of the place. [This contract was drawn up] in the presence of witnesses who are Jābir Muqbil cAbd al-Mālik the head of the al-cudayn agricultural [office], and Musllih Muhammad Nāyif [from] al-Sharācib, though God is the best Witness. [Additional] to this [contracted farm the aj $r$ will also tenant the farm in] the locality [called] Munākh al-Shaykh in its entirety which is bounded on the north and the west by the Wadi [cAnnah], on the east by the terraces owned by ${ }^{c}$ Awad and the road [to al-Farc], and on the south by the road. [This contract] was drawn up in the month of Muharram in the year $1407 \mathrm{AH}$. ...

\section{Document No.3}

In the name of God.

Hamūd ${ }^{c} A l i \bar{i}$ Qäyid, being of sound mind, came to us to [become] an aj7 $r$ of ${ }^{c} \mathrm{Abd}$ al-Wahid ${ }^{\mathrm{C}} \mathrm{Abd}$ al-Qawi bn Mulhi. [The farm in question] is the terraced area of al-Miqtār opposite the house of the tenant (musta'jir) which bounds [the farm] on the east, and on the west it [is bounded] by the Wädi Dābad, on the north by the road leading to the bed of the Wadi [cAnnah], and on the south by the property of Shaykh Sādiq bn Tāhā. The said person is an aj $r$ who is not a [land]owner. [The responsibility will be] on him to cultivate fully, to deliver the landowner's share of the harvest to the place [where it is to be] handed over, and to maintain the boundaries with the boundaries [of neighbouring properties]. [This contract was drawn up] in the presence of witnesses who are ${ }^{c}$ Abduh ${ }^{c}$ Abdallāh Sayf and Amin [son of] our sayyid Ghālib Abmad cAqlān, all of whom are from 
the town [i.e., al-cudayn]. [This contract] was drawn up in the month of Muharram in the year 1407 AH. ...

All three documents end with the pious set phrase kataba $a$ l-rāj $\overline{7} c_{a f w} r a b b^{i}-h$ (literally, he who hopes for his Lord's pardon wrote [this contract] - that is to say, the amin a 7-mabal7 himself), followed by his signature (cAbdallāh cAbduh ${ }^{c}$ Abdallāh) and his official stamp (cAbdallāh cAbduh / Am̄̄n of al-Sharācib and a1-cudayn / Yemen Arab Republic).

Apart from characteristics of style of the recorder these three contracts are very much the same in form and general content as others examined in the field. The names and place of residence of not only the tenant and the landowner but also the two witnesses are recorded and the plot which is to be tenanted is delimited by specifying the surrounding plots and the major bounding features such as main roads and watercourses. What is perhaps more remarkable is what is not specified in the contracts. Apart from the statements that the tenant is to deliver the landowner's share of the harvest to him and to maintain the boundaries of the land, the responsibilities of the tenant are not spelt out beyond giving the landowner samples of the crop if he should come to inspect it (in Document No.1), doing what it is customary for tenants to do (in Document No.2), and cultivating the land fully (in Document No.3). In particular, there is no statement of the proportion of the crop which is due to the landowner at the harvest, and even though all three contracts are sharecropping contracts, there is no indication which type of contract they are, whether muzäracah, mughärasah or musāqāh, as the Hadrami contract proformas discussed in the previous subsection (8.32) might have given cause to expect. Again, there is no statement of the responsibilities of the landowner. .

When questioned about why these details should be lacking both the aminn al-mahall and the head of the agricultural office at al-cUdayn pointed first to the phrase sälif al-balad (the precedent of the place) which occurs in Document Nos.1 and 2. "Everyone knows", they said, what was required by custom of both the tenant and the landowner, and therefore to write it in the contract would be superfluous. This must be so, but it does not explain why the 
responsibilities which are stated, and in particular delivering the landowner's share to him and maintaining the boundaries of the property, both of which figure in all three contracts, should receive special mention, since they too are presumably in accordance with local custom and known to everyone.

On the question of why the proportion of the crop due to the landowner (a half, a third, a quarter, or whatever) was not mentioned in any of these contracts, the head of the agricultural office added that it could not be put in writing in the contract since it was not a specific quantity which could be measured in units of capacity or weight before the total harvest had been measured. This is a curious statement and one which may possibly reflect a degree of uneasiness about the fact that any sharecropping contract by its nature involves an un-Islamic unknown in its conditions, a circumstance already discussed in chapters 2 and 3 above.

One is left with the strong impression then that even in areas where a contract is traditionally written a written contract is more of an aide mémoire than a legal document and that it is the verbal contract which has precedence as indeed is the case with Islamic contracts generally. The details of any sharecropping contract are well-known to all those involved in accordance with local customary law and do not have to be stated in writing.

\subsection{Sharecropping Contentions and Pleas}

8.41 The Field Evidence

The following are the main causes for dispute between the parties to a sharecropping contract as quoted by respondents in the field survey of Yemeni sharecroppers and landowners. For the reasons given below, no statistical frequencies can be coupled to the causes and indeed no significance can be attached even to the order in which they are listed.

- The tenant is guilty of taqs̄irr or ihmāl (both terms meaning negligence). (This was mentioned by several respondents in the field survey, though even so they constituted a small minority of the total respondents.) 
- The tenant absconds. (This was mentioned by only one respondent in the field survey.)

- The two parties to the sharecropping contract are unable to agree on the size of the yield to be shared.

- The owner of the water is late in supplying the water, or is unable to supply any at all.

- The landowner gives the tenant notice to quit so that he can work land himself. (This was mentioned by only one respondent in the field survey.)

- The landowner gives the tenant notice to quit so that he can build on the land. (This was mentioned by several respondents in the field survey, though all were referring to land in the immediate vicinity of $\operatorname{San}^{\mathrm{c}} \overline{\mathrm{a}}$, and they constituted a small minority of the total respondents.)

- The tenant is late in handing over the landowner's share of the crop or else its value in cases where the tenant has the responsibility of selling the crop as well as harvesting it.

- There are disputes over istah a1-judrān or bifz a1-budud (that is, the maintenance of the boundary walls, both in their physical upkeep and against encroachment by neighbours). Such disputes are not so much between landowner and tenant but rather between two neighbouring landowners.

The evidence from the field is that disputes would seem to be rather rare in reality and for this reason it is impossible to rank them in order of importance or frequency of occurrence. In fact, some of the reasons for dispute were mentioned by only one or two respondents. A tenant absconding, in particular, would seem to have a great fascination for Islamic jurists, though in practice such a phenomenon probably constitutes rather a rare event $\mathbf{2 7}$.

27 As has been seen in earlier chapters, the absconding tenant is an issue gone into by both the Zaydī Ibn al-Murtadā in a 7-Babr a 1-Zakhkhär (Chapter 5, Section 5.23) and the Shäfic $\overline{1}$ al-Nawawi in the Minhäj al-Tălibīn (Chapter 4, Section 4.32). 
If a generalisation can be made about present-day disputes it is that they would seem to be least frequent in sharecropping contracts involving annually sown crops (typically cereals and vegetables) and most frequent in contracts over perennial crops (fruit trees and, perhaps especially, qāt trees) - though the expression "most frequent" is entirely relative since even here disputes are by no means common. Moreover, when disputes do occur they are generally described by farmers as basīt (of no great importance, trivial), and the stated preference was for them to be settled bi-tarīa bukm curfi or bi-tarīa bukm qaba $\overline{7}$, both expressions meaning "by customary law", as opposed to Islamic Shar $\bar{i}^{c}$ ah law on the one hand and Yemeni civil law on the other.

\subsection{Three Plea Formats from Hadramawt}

Three examples of forms of plea which concern sharecropping have been published by R.B. Serjeant $\mathbf{2 8}$. Like the Hadrami model contracts discussed above (in Section 8.32) all three originate in South Yemen and take the form of models or proformas into which the specific details would be entered - in this case the names of the litigants and the details of the plea. Unlike the model contracts however, these model pleas apply, strictly speaking, only to musāqāh contracts in date-palms. Although this thesis is concerned primarily with northern Yemen rather than the south and Hadramawt and with all types of sharecropping rather than just musāqāh, it can perhaps be assumed, in the absence of new material being available to the present writer, that Serjeant's examples would be equally applicable in other areas of the Yemen where date-palms are grown, notably the plain of Tihāmah, which happens also like Hadramawt to be predominantly Shāficî̀.

The first and earliest of the three model sharecropping pleas made available by Serjeant occurs in an Ms. entitled al-Nubdhah a1-Muharrirah (or: a7-Muhabbibah) 1i-a7-Dacwa al-Mubarrirah which covers model pleas over a wide range of legal fields including the 
musāqā $h^{29}$. Serjeant gives the laqab of the author, a Shäfici from Hadramawt, as Bahraq, who died in 930/1524, together with a synops is of his 1 if $\mathrm{e}^{\mathbf{3 0}}$, and he puts forward the suggestion that

[Babraq's] object in composing the Nubdah may well have been the desire not so much to regularise pleas set forth in an unscientific manner as he states, but to extend the sar $\vec{i}^{\circ}$ ah into territory where 'ädah had prevailed ${ }^{\mathbf{3 1}}$.

The re-edited text is given in Appendix 3 and the following is the present writer's translation of the sharecropping passage from Bahraq's text as given by Serjeant.

I plead that this person So-and-so engaged me in a musāqāh contract over such-and-such a plantation $\mathbf{3 2}^{\mathbf{2}}$ of his to tend all the various kinds of date-palm in it, on the understanding that it would be my responsibility to irrigate [the trees], to care for them, to regulate the water channels, to keep the [irrigation] basins and channels in good repair, and to pollinate [the trees] and guard and harvest the fruit, and to do everything else necessary to make them produce fruit. In exchange for the labour necessary for this I would get a third, for example, of the fruit gathered from them. However, he refused to do this, or he decamped, for example, or he was negligent in his work. I am calling for him to fulfil what he was pledged to do.

It is clear from the ending that something is wrong with the text. The plea starts by being put forward by a tenant, whereas it ends with the landowner speaking, as Serjeant notes though he offers no explanation beyond saying that he suspects that something is missing in the text $\mathbf{3}^{3}$.

29 The passage on the musāaanh occurs at the top of p.11 of the published text (Serjeant 1955a :11).

30 Serjeant 1955a :1; Brockelmann :Supplement II, 554.

31 Serjeant 1955a :2. Similar conclusions have been arrived at in different regions and situations by other researchers (see e.g. Layish and Shmueli 1979).

32 The word used is ghaydah which more usually means a thicket or a jungle, though here it is obvious that cultivated trees are meant.

33 Serjeant 1955a:11 n.2. 
The other two model pleas which Serjeant has published are probably much more recent and come from an undated document from al-Mukalla $\bar{a}^{34}$. Happily, they hold the key to the anomaly within the Babraq document. The re-edited text as published is given in Appendix 3 and the following is the present writer's translation.

\section{(1) Model for the plea from a landowner in a Musāaāh contract}

Zayd $^{35}$ says: "I plead that I engaged this person ${ }^{\mathrm{c} A m r}$ in a musāqāh contract over such-and-such a plantation to tend all the various kinds of date-palm in it, on the understanding that it would be his responsibility to irrigate [the trees], to care for them, to regulate the water channels, to keep the [irrigation] basins which occur in the channels in good repair, and to pollinate [the trees] and guard and pick the fruit, and to do everything else necessary to make them produce fruit. In exchange for his labour he would get a third of the fruit gathered from them. However, he refused to do this, or he decamped, or he was negligent in his work. I am calling for him to fulfil what he was pledged to do. So, O Arbitrator ${ }^{36}$, command him to fulfil it."

(2) Model for the plea from a labourer 37 in a Musāqāh contract

cAmr says: "I plead that Zayd engaged me in a musāqāh contract over such-and-such a plantation to tend all the various kinds of date-palm in it, on the understanding that it would be my responsibility to irrigate [the trees], to care for them, to regulate the water channels, to keep the [irrigation] basins which occur in the channels in good repair, and to pollinate [the trees] and guard and pick the fruit, and to do everything else necessary to make them produce fruit. In exchange for my labour I would get a third of the fruit gathered from them. I

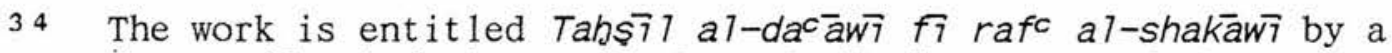
certain Sayyid Mubsin bn Jacfar bn ${ }^{c} A l a w \bar{i}$ Bu Numayy and the text concerning sharecropping has been published by Serjeant (1967:63) who notes $(: 63 \mathrm{n} .112)$ that he received the document in 1958 but he gives no further indication of when it was composed.

35 Zayd here is merely an example name the author of the document has chosen to represent the landowner in the case. He might just as well have said FuTan. The same applies to ${ }^{\mathrm{c} A m r}$ for the tenant later in the document.

\section{Ayyuhā a7-hākim.}

37 The expression used here is cāmil bi-muqābil camali-hi and could be translated sharecropping tenant in this context. 
am calling on him to do immediately what he is obligated to do concerning the fruit, since he has refused to do it. So, 0 Arbitrator, command him to hand it over to me."

The similarity in wording between these two model pleas on the one hand and that of Babraq on the other is so striking that it can be no mere coincidence. With the exception of some minor changes in the vocabulary (the substitution, for example, of bustān for Bahraq's ghaydah and of sawāq $\overline{\bar{\eta}}-h \bar{a}$ for anhär-hā) and the addition of the peroration addressed to the bākim, the text of the Mukalia pleas, when combined, is almost identical with Bahraq's text. It is clear that either both documents have the same original source, or else that the later (Mukallā) document was copied from the earlier (Babraq's) text. If the latter possibility is correct, then the author of the Mukallā document had a more reliable copy of Babraq's text than that published by Serjeant, since what has evidently happened in the case of the Bahraq document is that the model pleas for the two parties to a contract have become conflated into one, probably through a scribal omission of the end of the second plea and the beginning of the first.

As far as the content of these model pleas is concerned, there is little which could be considered unexpected. The lists of duties of the tenant, which occur in both the landowner's plea and the tenant's plea, are very much the same as those mentioned earlier in this chapter in the sharecropping contracts (Section 8.3) and more generally in the discussion of relations between landowner and sharecropper (Section 8.2). Similarly, the lists of possible causes for dispute in these model pleas (the tenant absconds, or he is negligent, and so on) are very reminiscent of those found in the legal works such as Ibn a1-Murtad̄à's al-Bahr al-Zakhkhär discussed in Chapter 5 (Section 5.23) above.

To what extent Serjeant is correct in suspecting that Babraq at least might have been aiming in composing his document to extend the Shar $\vec{i}^{c}$ ah into territory where curf had prevailed, as was quoted earlier, is perhaps debatable. At least, there would seem to be no internal evidence in Bahraq's model musāqāh plea to support the conjecture. Nor does the inclusion of the address to the bākim 
(arbitrator) in the Mukallā versions of the pleas make the supposition any more likely. The hākim in many cases could well be a Shar $\bar{i}^{c}$ ah $\overline{q a} \bar{q}_{\overline{7}}$, but it is equally possible for him to be a tribal shaykh, a local official (such as the aminn a7-maba71), or indeed anyone whose decision as arbitrator both parties to a dispute respect and agree to abide by.

Written collections of legal decisions or opinions (fatwās, pl. fatāwa) tend on the other hand to be the work of respected $\overline{q a} \bar{d} \overline{7} s$ and muftīs. The following Section (8.5) studies those fatwas which concern sharecropping in one such Yemeni collection.

\subsection{The Sharecropping Fatwas of Ibn Jacmān}

\subsection{The Manuscript and its Author}

A bound Ms. collection of the fatwās of a Yemeni Shāficī jurist, Burhān al-Dīn Ibrāhīm bn Mubammad bn Ibrāhīm Ibn Jacmān, belonged to the late Professor R.B. Serjeant by whose bequest it is now the property of the Department of Islamic and Middle Eastern Studies, University of Edinburgh. Serjeant has recorded that he purchased the Ms. in the Yemen in 1953-5438, and indeed an inscription on the page opposite the title colophon of the Ms. records the transfer of the work from the possession of a member of the Hadramī al-Saqqāf family to that of "Dr Serjeant" on 19th May 1954. Although Serjeant has referred to the collection more than once, as far as is known he never published a study of it.

Its author Ibn $\mathrm{Ja}^{\mathrm{c}}$ mān died in $1016 / 1607$ and so the fatwäs must date from the time of the first Turkish occupation of the Yemen. This accords with an imperfect and scarcely legible annotation below the title colophon which connects the author with the date $1016 \mathrm{AH}$.

Beyond the fact that Ibn $\mathrm{Ja}^{\mathrm{c}} \mathrm{ma} n$ was a Shäfic $\bar{i}$ jurist of the early seventeenth century little else is known of him ${ }^{\mathbf{3 9}}$. That R.B. Serjeant obtained the Ms. from a member of the Hadramī al-Saqqāf family in Hadramawt is suggestive that Ibn $\mathrm{Ja}^{\mathrm{c}} \mathrm{ma}$ n was a local scholar of the predominantly Shäfici Hadramawt. Further, of the 
only two authorities Ibn $\mathrm{Ja}^{\mathrm{c}}$ mān quotes in the Băb al-Musāqāh, one is called Abū Qushayr who, although no more identifiable so far than Ibn $\mathrm{Ja}^{\mathrm{c}} \mathrm{ma} n$, has significantly the nisbah al-Hadramī. Moreover, Ibn Jacmān's fatwās on sharecropping deal with the subject exclusively in the context of irrigated date-palms, a type of agriculture typical of Hadramawt.

On the other hand, several pieces of evidence suggest that a Tihāmah provenance is equally possible and indeed perhaps more likely. The coastal plain of Tihāmah in western Yemen is also a Shāfic $\bar{i}$ area and date-palm growing is as much a characteristic of this region as of Hadramawt. Further, the quoted authority Abu Qushayr al-Hadramī is unlikely to have been resident in Hadramawt, since such a nisbah would be applied only outside the region. It is indeed very possible that Abū Qushayr al-Hadramī was a member of the scholarly Shäfic $\bar{i}$ family with that nisbah who have been long-established in Zabīd, the capital of Tihämah, and who are indeed still resident there. However, further research on Ibn $\mathrm{Ja}^{c} \mathrm{ma}$ ' $s$ background is clearly necessary since the above is so far largely speculation.

\subsection{2 observations on the Manuscript}

The bound Ms. of some 330 folios is the work of a single copyist (though there are occasional short marginal additions or amendments which may be in a different hand). It is written in a large naskh which is for the most part clear and there are 22, 23 or 24 lines to the page. Black ink has been used throughout except for the frequently recurring words mas'alah (topic, issue) and ajāba ([the Shaykh] replied) which are mostly in red and in a larger bolder script. As is common practice with bound Mss. to ease collation and

39 The fact that he was a Shäfic $\bar{i}$ was held by R.B. Serjeant (personal communication). Maktari (1971a :23 note 3 ) also includes him with the Shäficiss. The standard reference works (including the Encyclopaedia of Islam and al-Mawsüeah al-Yamanīyah) do not list Ibn $\mathrm{Ja}^{\mathrm{c}} \mathrm{ma} \mathrm{n}$. 
binding, the first word or two of each left hand page is rewritten at the foot of the preceding right hand page.

The orthographical peculiarities found in the Ms. are commonly found in other such works (for example, alif mamdudah for dagger alif or alif maqsürah; hamzah missing or replaced by $\overline{y a}$ ') and require no special consideration, and with a very occasional exception the Ms. text is clear enough for the Arabic to be readable throughout. The language is largely good fushā with little colloquialism and although it does incorporate, as one might expect, a few specialised or local terms, all have been encountered elsewhere (for example, abāj̄̄n, and various terms associated with pollinating, which have been discussed earlier in this present chapter) and present no difficulty. Difficulties remain however at certain points as to what precise meaning is intended and how best to reflect the meaning in English.

As is usual with such collections Ibn Jacmān's collected fatwās cover the gamut of religious observance, family law, contracts, and other matters. One of the chapters, entitled Bāb al-Musāqāh, is the only part of the work to concern sharecropping and is made up of six fatwās. There is no section on the muzäracah or the mughärasah. This may be because musāqāh is the commonest system in the lowland Shāficī areas of the Yemen and Ibn Jacmān was never asked to give an opinion which concerned the other types of sharecropping contract. The absence of fatwass on the muzärac ah and the mughärasah is unlikely to be because of any Shäfic $\bar{i}$ aversion to such contracts. After all, even muzāracah contracts, the most problematic of all for Shāf $i^{c} \bar{i}$, are permitted in certain limited circumstances by Shāfici jurists, as was seen in Chapter 4 , while the model contracts studied in section 8.32 above include all three types despite being by a Shāfic $\bar{i}$ author.

A photocopy of the original Ms. text of the sharecropping fatwas together with a transcription and translation by the present writer are given in Appendix 4 of this thesis. 


\subsection{The Structure and content of the Fatwas:}

In the Băb al-Musāāàh (and indeed throughout the collection), the Question and Answer structure of each fatwa is very clearly marked. Each fatwā starts "mas'alah" (Question or Issue), spelt defectively, to introduce the circumstances and the legal question to which they give rise. Then the fatwa proper begins with the words "ajāba shaykhu-nā" (Our Shaykh responded), and each ends with the pious formula: "wa-AlTahu cazz wa-jall aclam" (God knows best). This is a common pattern in fatwas and is in no way remarkable.

In these six musāaāh fatwās Ibn Jacmān cites explicitly only two other authorities, and both are of the same view as Ibn $\mathrm{Ja}^{\mathrm{c}} \mathrm{ma}$. These are named as Shaykh al-Mashāyikh al-cAllāmah ${ }^{c}$ Abd al-Rabmān Ibn Ziyād (in Fatwā 1, lines 12-13; and Fatwā 3, lines 9-1040); and Abū Qushayr al-Hadramī, the author of a so far unidentified work called al-QaTa'id (in Fatwa 1, line 13). As has been remarked already, no details have yet been traced of Abū Qushayr. Ibn Ziyād, however is almost certainly the known authority cAbd al-Rabmān bn cAbd al-Karīm bn Ziyād al-Muqriši al-Zabĩdî, who died in 975/1567 (that is, only forty years before Ibn Jacmān's death and perhaps known personally to him) and was the author of a short work on regulations connected with agricultural holdings called Muz $\overline{7}$

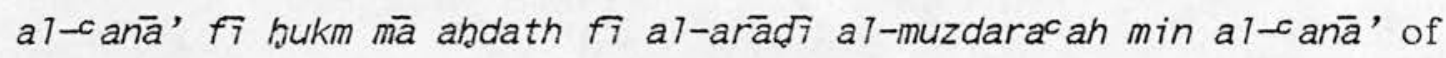
which there are three copies known ${ }^{41}$. The present writer has studied one of the copies but the subject matter concerns agricultural problems other than sharecropping42. It is therefore clearly not this work of Ibn Ziyād's that Ibn Jacmān is referring to

40 The sharecropping fatwas have been numbered 1 to 6 for the purposes of this discussion only. They are not numbered at all in the original Ms.

41 Two Mss. of the work exist in Sanc $\bar{a}$, and are available on microfilm in Kuwait, as listed in al-Shanti 1988 (items 249 and 250). The photocopy of a third Ms. (estate of the late Mrs R. Cedzich) is held in the library of the Seminar für Orientkunde, Mainz (though the whereabouts of the Ms. from which it was copied are not known). 
in two of his fatwās, but the identification of the same Ibn Ziyād is considered probable nevertheless.

The content of the six fatwās may be summarised as follows:

\section{(1) Situation:}

The situation here concerns negligence on the part of the tenant which leads to the loss of part of the yield. The question put to Ibn $\mathrm{Ja}^{\mathrm{c}}$ mān is whether the tenant is to be held liable for the shortfall.

Decision:

The tenant must compensate the landowner and $\mathrm{Ibn} \mathrm{Ja}^{c} \mathrm{ma} n$ quotes al-QaTa'id of Abü Qushayr al-Hadrami to give the method to calculate the loss, which, unfortunately, is rather difficult to interpret. It would seem to have as its basis the separate estimation of the value of the lost fruit on the one hand and the damage done to the date-palms on the other.

(2) Situation:

This situation is introduced as an accusation by one of the two parties to a musāaāh contract that the other had not handed over his share of the harvest. A witness however testifies to the fact that the renewal of the musāqāh contract was not confirmed. The question is therefore whether the plaintiff has legal grounds to demand his share of the fruit.

Decision:

Since the contract was not properly renewed, the plaintiff has no case against the accused and is not entitled to a share of the fruit.

\section{(3) Situation:}

The situation here again concerns negligence on part of the tenant leading to a loss of part of the yield.

42 The 13-page Mainz copy has been studied. There is only one short and not very revealing reference to muzarracah in the work. I would nevertheless like to acknowledge greatly the generosity of $\mathrm{Mr}$ Nadim Hosny Salameh and Professor Manfred Kropp, both of Mainz University, for providing me with a photocopy of the document and for allowing me permission to quote from it if necessary. 


\section{Decision:}

The responsibility lies with the tenant to ensure that the date-palms are well looked after, including that they are properly pollinated. Ibn $\mathrm{Ja}^{\mathrm{c}}$ mann then adds that the aim of this ruling is to ensure that the landowner gets his proper share since, he would seem to say, no compensation can be payable to the tenant since his loss was caused by his own negligence.

\section{(4) Situation:}

Here again, the question is mainly one of negligence on part of the tenant which results in the loss of part of the yield. The negligence this time is specified as neglecting the date-palms by his failure to irrigate them and to protect the fruit from animals and birds. In addition, the tenant stole some palm fronds ( $s a^{c} a f$ ) to which he was not entitled. As a result, one of the parties (most probably the tenant) abused the other (the landowner).

Decision:

The tenant must compensate the landowner for the palm fronds he has stolen and also for any damage he may have done to the date-palms by his negligence. Ibn Jacmān says how the compensation for the damage should be calculated, though unfortunately the Arabic is somewhat cryptic here. Concerning the abuse the perpetrator must be punished with a $t a^{c} \bar{z} \bar{r}$ (discretionary) reprimand by the legitimate arbitrator.

\section{(5) Situation:}

The circumstances here are essentially a case of a tenant dying before the end of a one-year contract, though they are complicated by the fact that the land is owned by minors for whom their mother is guardian. On the death of the tenant within the period of the contract the tenancy is assumed by his heirs. The problem arises when the heirs continue to work the palms and take the fruit after the expiry of the contract. The situation would seem to be that the heirs of the original tenant are trying to take advantage of minors' rights when their guardian is a woman (though this not not explicitly stated). The question put to $\mathrm{Ibn} \mathrm{Ja}^{\mathrm{c}} \mathrm{ma} n$ is whether or not the 
tenant's heirs are legally bound to return the fruit they have illegally taken or else its equivalent value if it has already been eaten.

Decision:

For the valid period of contract (that is, the first year) the heirs of the tenant and the minors are to share the fruit. (This implies, though it is not explicitly stated, that the death of the tenant does not cancel the contract.) If the heirs have not shared the fruit with the minors but have rather held onto all of it, then they must return the minors' share if it still exists or else its equivalent if it has already been consumed. As for the fruit harvested after the end of the first year, the heirs have no justification in retaining any of it and they must either return it all or else return its equivalent value.

(6) Situation:

This situation concerns a landowner who found the yield of fruit from his date-palms at harvest deficient and ascribed the deficiency to negligence on the part of the musäq $\overrightarrow{7}-t$ enant in properly pollinating the date-flowers and protecting the developing fruit from animals, birds and insects. The questions put to Ibn $\mathrm{Ja}^{\mathrm{c}}$ mann are, first, whether the tenant is bound to compensate the landowner for the lost fruit from his own share, and second, whether certain specified activities are indeed the duty of the tenant. The list of duties specified here is almost identical to other lists seen in contracts and pleas earlier in the current chapter $\mathbf{4 3}^{\mathbf{3}}$.

Decision:

If the tenant's negligence has indeed been the cause of the loss of some of the yield, he must compensate the landowner for

43 The activities which are specifically mentioned here are: pollinating the spadices; protecting the fruit from animals, birds and flies; keeping the wells in good repair; clearing grass out of presumably the water channels and the land generally; keeping the abajin (the irrigation hollows at the bases of the palm-trees) in good repair; and keeping the walls in good repair. 
the amount of the loss. Nevertheless, he has a right to his full share of the fruit which has appeared.

The duties of the tenant are also clarified in this fatwa. The situation may be summarised generally as follows: any labour required for investment in capital infrastructure (mentioned here are "digging and building") is the responsibility of the owner. On the other hand, the labour for day-to-day operational maintenance (such as clearing and opening the water channels, keeping everything clear of grass, and keeping the banks and the well wall in good repair) is responsibility of the tenant.

In sum, then, four of Ibn Jacmän's six fatwās concern, partly or wholly, negligence on the part of the tenant (Nos. 1, 3, 4 and 6). The other two concern, partly or wholly, the renewal of a musāaāh contract (Nos. 2 and 5). In addition, the duties of a musāqāh tenant are spelt out (especially in No. 6). All the fatwās concern to some extent the need to compensate the wronged party (which is exclusively the landowner), and in two of them (No. 1, 1 ines 8-10, and also No. 6, lines 14-15) Ibn $\mathrm{Ja}^{\mathrm{c}} \mathrm{ma} n$ sets out the basis on which the compensation for lost fruit is to be evaluated. Much of the material is repetitive, and especially concerning the duties of the tenant, the content is very reminiscent of the other sources which were discussed in earlier sections of this chapter.

Perhaps one point is worth making, however. As has been seen, the fatwās delivered by Ibn $\mathrm{Ja}^{\mathrm{c}} \mathrm{ma} n$ on sharecropping and preserved in this collection number only six - six, that is, out of a total of what must be over 1,000 in the collection. The Bäb al-Ijarah (leasing), the section which follows the Bäb al-Musāāah and which concerns the type of contract most like sharecropping, contains some 72 fatwas, and the Bäb al-Bayc (sale) is even longer. One must ask therefore why sharecropping has received so little attention from Ibn Jacmān.

Could it be that around 1000/1600 sharecropping was little practised in the Yemen? Such an explanation would seem unlikely given its great importance today and given also the considerable 
attention devoted to the practice by Yemeni jurists throughout the centuries in their works of figh from Ibn al-Murtada in the second half of the $8 \mathrm{th} / 14 \mathrm{th}$ century to al-Shawkānī in the early 13th/19th.

Could it be that Ibn $\mathrm{Ja}^{c}$ mann had little interest in the subject and therefore discouraged people from referring problems to him on it? This would similarly seem somewhat unlikely. The Yemen today is still an overwhelmingly rural and agricultural society44. In Ibn $\mathrm{Ja}^{c}$ mān's day it would be even more so. It is improbable that an eminent $\overline{q a} \bar{d} \overline{7}$ and muft $\overline{7}$ could close his eyes to what must have been a dominant agricultural practice and especially one which was legally problematic.

A much more likely reason for the very small number of sharecropping fatwās in the collection is a fact that was mentioned earlier in the chapter when the field evidence on disputes and contentions was discussed (Section 8.41), namely, that sharecropping, in at least present-day Yemen, would seem to give rise to rather few disputes. Whether or not this is the true explanation, the field evidence on the matter is at least consistent with Ibn Jacmān's small number of cases.

\subsection{Concluding Remarks on Contracts and Contentions}

It has been the purpose of this chapter to examine from a range of sources, including both documentary evidence and the field survey, some aspects of the contractual relationship between landowner and sharecropper in the Yemen. It has been shown how important the precedence or custom of the area is in determining the exact nature of the terms of sharecropping contracts in matters such as the provision of agricultural inputs. At the same time it is striking how similar are the concerns of contracts, pleas and fatwäs in what sharecropping tenants are required to do, and yet how they are

44 As was stated in footnote 5 of Chapter 7 of this thesis, in the 1986 census (the latest available to the present writer), the projection was that by 1990 some $79 \%$ of the population of the northern part of the country ( $8.86 \mathrm{million}$ out of $11.28 \mathrm{million})$ would still be rural (Yemen Republic 1991 :Table 2). 
almost silent on any possible infringements which landowners might commit. This appears to be so no matter whether the source or area is Shäfici or Zaydī, since the materials covered here embrace both. Further, it has been put forward from both the field evidence and the small number of the Ibn $\mathrm{Ja}^{c} \mathrm{ma} n$ fatwas that serious disputes between the two parties to sharecropping contracts in the Yemen are probably not very common in practice, despite the essentially verbal nature of the contracts and the potential theoretical problems posed by sharecropping in Islamic law. 


\section{CHAPTER 9 : CONCLUSIONS}

Sharecropping land is a widespread and ancient form of tenancy, the basic principle of which - rent as a proportion of the harvest might seem at first sight so simple as to require little discussion. This thesis has tried to show that this is not so and that sharecropping in the Islamic context is a highly complex subject and one, moreover, on which the Islamic jurists are very far from consensus.

As has been seen, some of the complexity of the practice is reflected in the Arabic terminology and in the relationship between the contribution of inputs on the one hand-and, on the other, the proportional size of the share of the harvest. Both of these aspects have been examined in the thesis, especially as they are reflected in the Yemen. Further, sharecropping is not confined to sharecropping land, since animals too can be "sharecropped", as has also been shown.

The basic problem of sharecropping for Islamic law has also been addressed and, as has been seen, it has two related strands. First, there is the ambiguous nature of the sharecropping hadiths, the point at which all legal discussion must start. Second, there is the more general Islamic injunction against gharar in contracts, and yet some measure of uncertainty or risk is inherent in the very principle of sharecropping.

The Imām al-Shäfici resolved the question of gharar, at least to his own satisfaction (though, as it turned out eventually, not quite to the satisfaction of his followers), by limiting the validity of sharecropping to musāqāh contracts, in which the trees are extant at the time the contract is made and may form the valid basis for estimating the size of the future harvest. This was a clearly defined and easily comprehensible stance to take, even if a somewhat narrow, literalist one. By the time of al-Nawawi, however, 
the position of the Shäf $i^{c} \bar{i}$ School had become somewhat less purist. As has been shown, al-Nawawī allowed, in addition to musāqāh, a limited form of muzāracah, through having to admit the practical difficulty of excluding from the musāqāh annual crops which are grown under and beside irrigated trees, since those too would benefit from the same water and the same labour as the trees of the legitimate contract. It would appear, in other words, that the purist, narrow ruling of al-Shāfici had eventually to bend, even if only a little, when confronted by practicalities.

The Shäfici position, even in its developed form as attested by al-Nawaw $\bar{i}$, is indeed particularly interesting from the point of view of a gulf not between the Shar $\bar{i}^{c}$ ah on one hand and practice on the other, but rather between the theories of some jurists on the one hand and the practice of those physically involved in the system on the other. Although from the theoretical Shäfici standpoint, only musāqāh and a limited form of muzāracah are valid, it has nevertheless been shown in this thesis that not only do other forms of sharecropping exist in practice in Shäfic $\bar{i}$ areas of the Yemen, but at least one Shäfic $\bar{i}$ writer actually provides model contracts (examined in Chapter 8, Section 8.32 above) for the "un-Shāfic $\overline{1}$ " forms of muzāracah and mughārasah.

On the question of the ambiguity of the sharecropping bad7ths, the point of view has been put forward that a close reading of the texts of those badiths which seem to prohibit sharecropping can lead to the conclusion that it was not the Prophet's intention to prohibit the practice in and for itself, but rather only those forms of it which might be unfair to the sharecropper. Such is the view of the pragmatic al-Shawkānī, as was seen in his discussion of the subject in the Nayl al-Awtär. He, like his Zaydi predecessor al-Mahdi Ibn al-Murtadā, allows all the three main forms of sharecropping, and declares invalid only those variations which include potentially unfair stipulations, such as sharing systems based on the production of different parts of the land. It is this Zaydi stance, rather than the narrower Shäfici stance, which is reflected in the Yemeni Civil Code al-Qanūn al-Madan̄i. 
A further theme running through the discussion of Islamic sharecropping and Yemeni sharecropping in this thesis is the position of the customary law, the curf. The importance of curf both as part of Islamic law and as a complement to statute law has been outlined in general terms, and, regarding specifically sharecropping, it has been shown that the Islamic legal authorities, including even the Shäficī School as exemplified by al-Nawawī, refer the reader to curf where there is no specific guidance otherwise available. So also does the Yemeni Civil Code a 7-Qanūn a 1-Madan̄̄ (as, for example, in Article 736 concerning the mughärasah, and in Article 738 on how to treat crops with more than one harvest per year). In discussing Yemeni contracts and disputes it has. similiarly been shown how important the role of curf is in regulating sharecropping and how frequently there occur phrases which point to the relevant custom as the arbiter of the practice: phrases such as salif al-balad (according to the precedence of the place, as in the first and second of the al-cudayn contracts), or basab a $7-$ urf (according to custom, as in the responses of many Yemeni farmers interviewed in the field survey when asked why there should be such variation in the way sharecropping is organised), or al-curf al-ghālib (the dominant custom, as used by al-Nawawi when he indicates how a contract should be worded1), or 1i-curf al-jihah (according to the custom of the district, as in Article 736 of the Yemeni Civil Code, al-Qānun a 7-Madan̄i).

In short, whatever the difficulties concerning sharecropping that certain Islamic jurists may raise, this system of land tenancy is nevertheless sanctioned by custom and practised in Islamic countries. This is so not least in the Yemen.

1 Al-Nawawī Minhāj al-Tălibīn :II, 1472-s. 
APPENDICES

- 261 - 


\section{APPENDIX 1 \\ GLOSSARY OF TERMS FOR ISLAMIC SHARECROPPING CONTRACTS}

The following table summarises all the Arabic terms for sharecropping contracts found by the present writer in literary sources and in addition those he has collected from verbal sources in the Yemen. The entries are in the Arabic alphabetic order of the root. It will be readily observed that the large majority of the terms are of the pattern mufacalah (that is, the most common pattern for the verbal noun of Form III verbs) which implies a reciprocal relationship appropriate for contracts between two parties. It should be noted that some of the terms have other meanings in other contexts (e.g. muhāqalah, mushārakah, munāsafah).

A. TERMS FOR SHARECROPPING PROPER:

\section{Root Tern Coments}

'-j-r 1. mu`ajarah

'-k-r 2. mu `akarah

b-dh-r 3. mubādharah

b-q-1 4. musāqalah
According to Haque $(1977: 10)$ this is a land tenure contract of the sharecropping type, though given the root from which the term comes, it should apply more generally to leasing or hiring contracts. Cf. ajr (renting, wage).

Haque (1977 :19) for example uses the term to mean sharecropping. Cf. akara (to plough, cultivate).

The term is sometimes applied to contracts where the landowner provides the seed corn (see Løkkegaard $1950: 175$ ). Cf. badhr (seed).

This term is sometimes applied to a land tenure contract of the sharecropping type (see Haque $1977: 10$ ), though in most cases it has a more specific application (see the section above on terminology in Section 2.3 of this thesis). Cf. baq 7 (field).

baq 1
Variant of mubāqalah, as used for example in Muslim Hadith 3756. 
kh-b-r 5. mukhäbarah

khibr

kh-1-c 6. mukhä7acah

d-f-c

7. mudāfacah

$\mathrm{z}-\mathrm{r}-\mathrm{c}$

8. muzāracah

s-q-y 9. musāqāh

s-h-m 10. musāhamah

sh-r-b 11. shiräbah

sh-r-k 12. mushärakah
Widely found term. The etymology is not certain, and there are several suggestions (see the section above on terminology in Chapter 2 (Section 2.32) of this thesis).

Variant of mukhäbarah.

Serjeant notes this term in the Hadram $\bar{i}$ context, though he does not offer an explanation of its etymology (1964:62 n.110). It may well be connected with the term khalcah which is found in Yemeni sources meaning date-palm (Serjeant 1964 :67 n.135).

Al-Shawkānī (Nayl a 7-Awtār V :279) for example uses the term to mean sharecropping. $\mathrm{Cf}$. $\operatorname{dafa}^{c} a$, which in the context of sharecropping is frequently the verb used in the literary sources to mean "[ the landowner] hands over [land to the sharecropper]".

A widely found term meaning sharecropping, often specifically on annually sown land. Cf. zarc (1. sowing; 2. grain, seed; 3. crop; 4. cultivation, agriculture).

A widely found term referring to sharecropping in irrigated gardens, usually with perennial crops, especially date-palm gardens. Cf. saqy (irrigation).

Cf. sahm (share, portion).

The term is heard in the piedmont zone of the Tihämah plain meaning sharecropping in banana plantations. Serjeant (1964 :65a; and 1981a :307) has recorded the same term in Hadramawt meaning date-palm protection. Cf. sharaha (to slice up).

Although the term is used to mean sharecropping it is also more generally applied to commercial partnership agreements (see e.g. Rayner 1991 :72; Latham $E I^{2}$, article "Mushāraka"). Cf. shāraka (to share, participate). 
sharäkah The usual term for sharecropping among Yemeni farmers and farmers elsewhere in the Arab world. Variant of mushärakah.

shirk Variant of mushärakah.

gh-r-s 13. mughärasah Widely found term generally applied to sharecropping contracts in orchards (i.e., perennial crops, as opposed to annually sown crops, for which the term is properly muzäracah (q.v.)). The saplings are of ten provided by the sharecropper (as discussed in Chapter 3 (Section 3.4 above) and elsewhere in this thesis). According to the Bā Kathīr Ms. (:11), the term mughärasah is the usage of the people of Medina, and means the same as munasabah (q.v.) and mufakhadhah (q.v.). Cf. ghars (plant, planting).

f-kh-dh 14. mufákhadhah According to the Bā Kathīr Ms. this and its variant fakhdh are the terms for sharecropping contracts in Hadramawt and are identical in meaning with mughärasah and muñasabah (Bā Kathīr Ms. :1111-14 and 1120-121). The author of the Ms. admits ignorance of the etymology, though Serjeant, who has also noted the term (in the Hadramī Bā Sawdān Ms., as discussed in this thesis (Chapter 8, Section 8.33)), affirms that the verb fakhadha means to divide (1964:62 n.110). Since however this meaning occurs nowhere in the usual lexicons it is possible that the verb is a derivative of the name of the sharecropping contract mufakhadhah/ fakhdh, rather than that the latter has derived from the verb. It may well however be significant that Landberg (1920-42 : III, 2402 , root $f-k h-d h)$ gives fakhdh, (pl. fukhüdh) as subdivision d'um tribu.

fakhdh Variant of mufakhadhah.

q-s-m 15. muqāsamah

Although the term is sometimes used to mean sharecropping it is more usually applied to a proportional tax on crops (Løkkegaard 1950 :102-103, 109-110, 120), though in cases where tenants work on land of which the state is the landowner, then the distinction between $\operatorname{tax}$ and rent can 
become blurred. Cf. qism (share, portion).

n-sh-r 16. munāsharah

n-s-b 17. munāşabah
The term perhaps implies that the produce is "spread" between the two partners in the contract. (Cf. nashr (spreading).) Although Serjeant asserts that nishr means sharing a crop and nashara means to give land to someone else to cultivate (1964 :62 n.11), it is not clear whether these are primary meanings or whether rather the verbal meaning has derived from the name of the sharecropping contract munasharah.

The term is used in the second of the Hadrami model contracts discussed in CHapter 8 (Section 8.32) of this thesis and is a synonym of mugharasah (q.v.) and mufakhadhah (q.v.). According to the Bā Kathir Ms. $(: 1120-121)$, the term is used by the people of a1-Shām to mean mughärasah (q.v.). Cf. nas̄īb (share, participation).

According to Köhler ( $E I^{2}$, article "Munaşafa"), the term is found in treatises on muzäracah to mean harvest sharing but is also used to mean tax sharing especially between Muslim and non-Muslim communities in the mediaeval context. Cf. nisf (half). 
B. YEMENI TERMS FOR SHARECROPPING ANIMALS:

Root Term Coments

r-b-c 19. muräbacah From root $r-b-c$ ("four-ness"). The term is used by farmers in the Dhamār and Radāc areas of North Yemen to mean a contract for sharecropping animals.

ribāc Variant of murābacah and used by farmers in the same areas of North Yemen.

r-b-w 20. murābāh

From root $r-b-w$ (upbringing, rearing). The term is used by farmers in the central Tihāmah area of North Yemen to mean a contract for sharecropping animals.

ribāa Variant of murābāh used by farmers in the area to the SW of Sanc $\bar{a}$ '.

$\mathbf{r}^{-\mathbf{c}}-\mathbf{y}$ 21. $\operatorname{taracc}_{\bar{a}} \quad$ From root $r-c-y$ (grazing, tending). The term is used by farmers in the ShibāmKawkabān area of North Yemen to mean a contract for sharecropping animals.

sh-t-r 22. mushātarah From root sh-t-r ("halving"). The term is used by farmers in the Dhî̀ al-Sufāl, al-Q̄ac idah and al-c Udayn areas of North Yemen to mean a sharecropping contract involving animals.

shitär Variant of mushätarah used in the same areas of North Yemen.

shatar Variant of mushätarah used in the same areas of North Yemen. 


\section{APPENDIX ?}

\section{ARABIC TEXT OF THE ARTICLES DEALING WITH SHARECROPPING}

\section{IN THE YEMENI CIVIL CODE a 1-Qänün a 7-Madañ̄}

The text of these Articles has been summarised and discussed in Chapter 3 (Section 3.5) of this thesis.

\section{ألقانون المدني : المعاملات المشرعية}

الكتاب الثالث : العقود المسماة في الفقه الشرعي

القسم الثاني : العقود التي تقع على المنفعة وإلعمل

$$
\text { الباب الأول : عقد الإيجار الآجارةه) }
$$

$$
\text { المغارنة والمزارعة والمسأثات }
$$

$$
\text { الفرع الاول : المفارسة }
$$

$$
\text { : MLT - MLT }
$$

المغارسة الشحيحة أن يستأجر هالك الأرض من يفرس قدرا معلومتا من أرضه بغرس

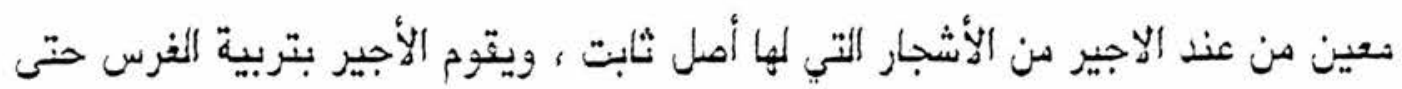

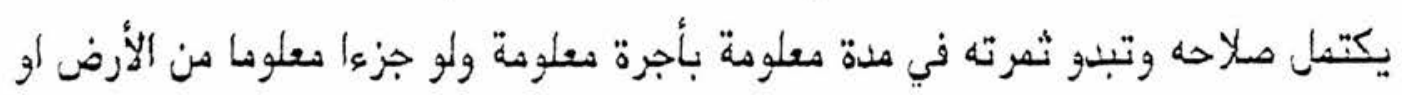

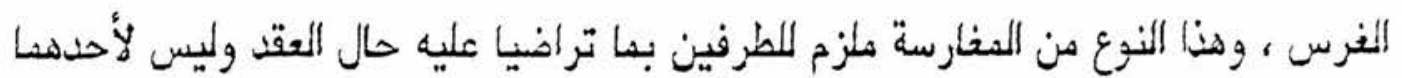
الفسخ ، ولا تعود الأرض كاملة المى مالكها إلا بذهاب كامل الفرس او باتفاق الطرنين .

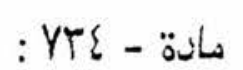

إنا أختل شرط أو أكثر من شروط الصحة فالغروس للغارس واليه أجرة المثل ، وعند التفسخ يخير الفارس بين تفريغ الأرض بقلع المغروس ، ويرجع بنقصانها وهو ما بين قيمتها تائمة ليس لها حق البقاء وقيمتها مقلوعة أو تركها لرب الأرض وأخذ قيمتها قائمة ليس لها لها حق. البقاء . 
ها وضع بتعد من غرس أو بناء أو نحوهما وجب على واضعه إزالته وتسليم الرش الأرض

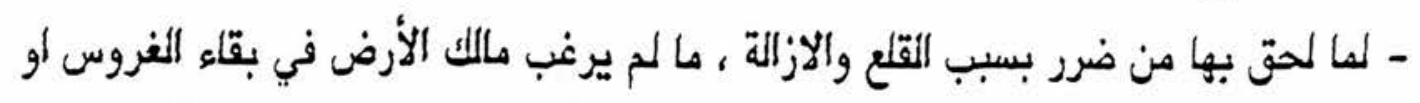

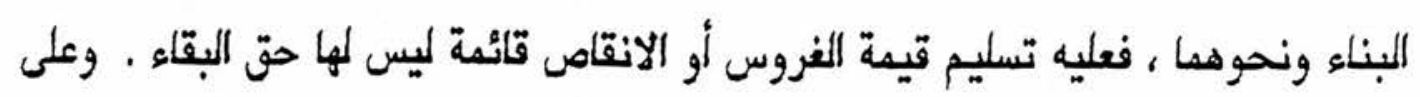
الواضع تعديا أجرة الأرض بما يقدره عدلان وارش جناية ها أحلدثه . هائة - TT Y

ها لم يرد حكمه في المواد المتقدة يرجع فيه لعرف الجهة .

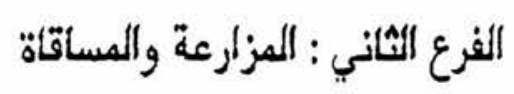

مادة - YYY

إذا أجر رب الأرض أرضنا معلومة لشخص آخر ليزرعها زرعًا هعلوتا هدة دعلومة كان

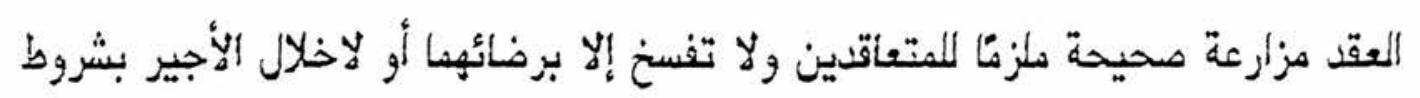
الاتقانة المتفق عليها حال العقد ، أو امتناعه عن تسليم الأجرة . مادة - YTA

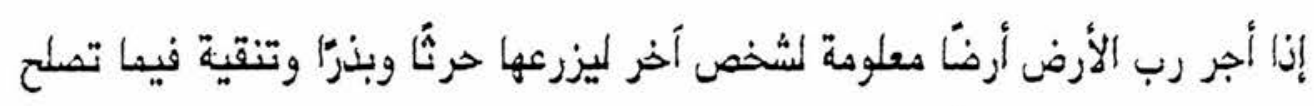

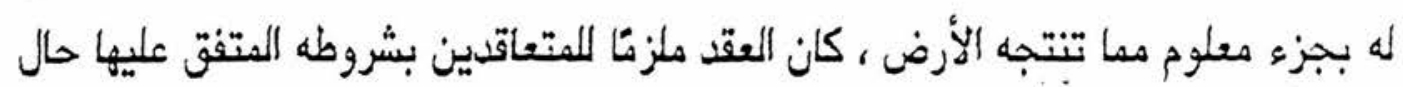

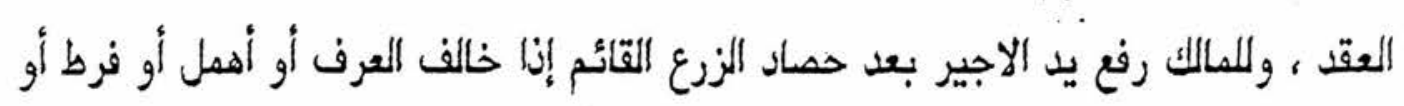

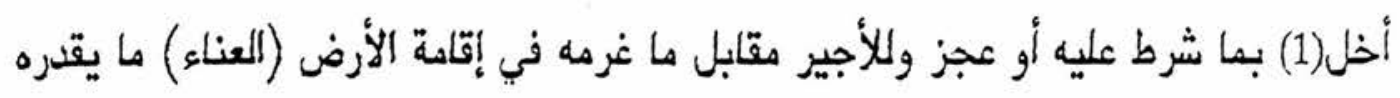

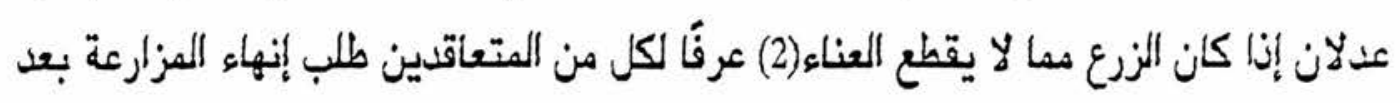

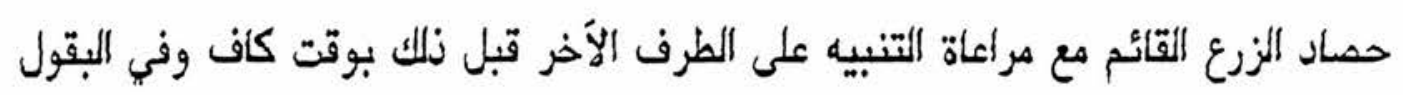

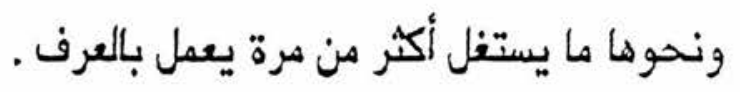


لا يجوز تأجير جزء من الأرض يزرعه الأجير المالك مقابل إعطلاء الأجير جزءا أخر

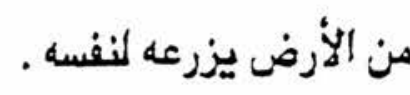

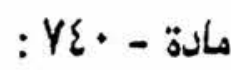

لا يجوز المززارع أن يتنازل عن الأرض أو يؤجر ها لغيره إلا باذن المؤجر .

مائة - Y (Y)

إذا ترك الأجير المقصود من العمل بعد أن حرث وأصلح الأرض ولم يزرعها فان

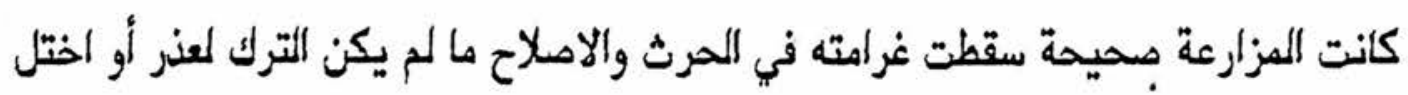

فيه شرط من شروط الصحة استحق الأجير غرامته بما يقدره عدلان .

الثاني : المساقأة :

هادة - Y Y

المساقة الصحيحة هي أن يستأجر مالك غرس أو زرع شخصا لاصلاح غرسه أو

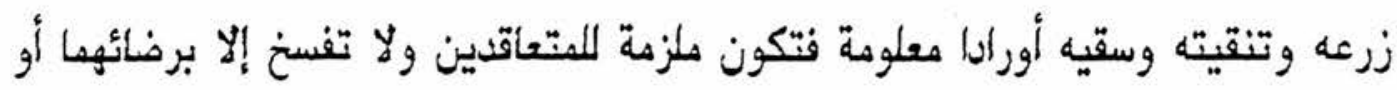

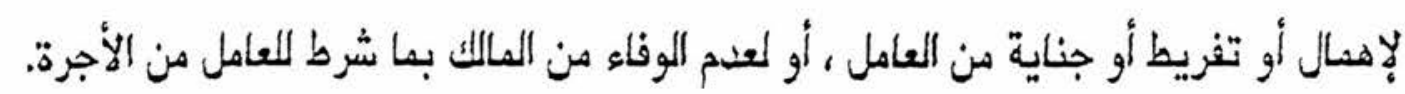

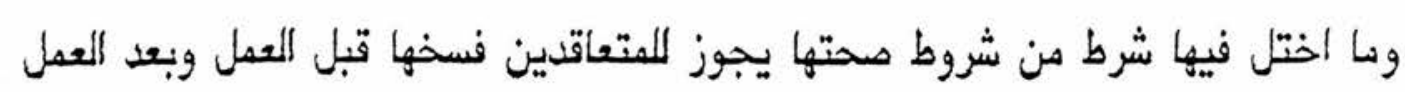

يستحق العامل أجرة المثل عما قام به من عمل .

مادة - Y Y Y

لا يجوز للعامل أن يتنازل عن المساقة لغيره إلا باذن المالك . 
إذا اختلف المالك مع الأجير أو العامل على الأجرة فالقول قول نافي الزيادة ، وإذا

اختلفا في الآن فالقول للمالك في نفيه .

\section{المذكرة الإيضاحية للكتاب الثالث من القانون العدني

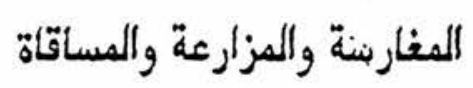

(pp. 317 - 320)

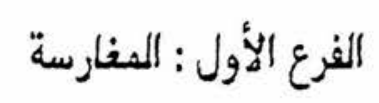

مائة - VTT

عرنت المغارسة الصحيحة وهي التُقاقد بين مالك الأرض والفارس على أن يغرس في

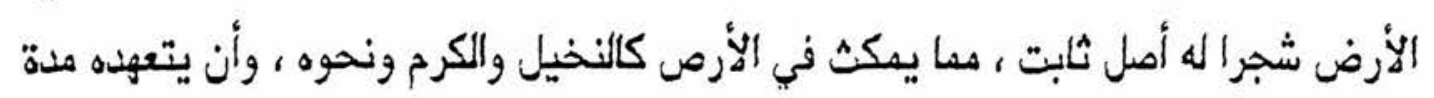

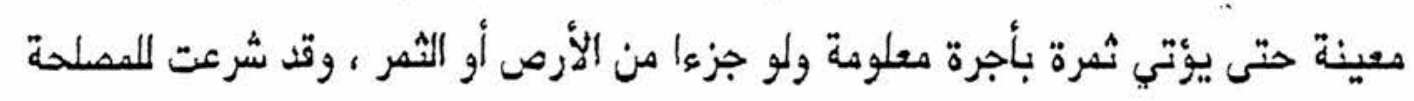

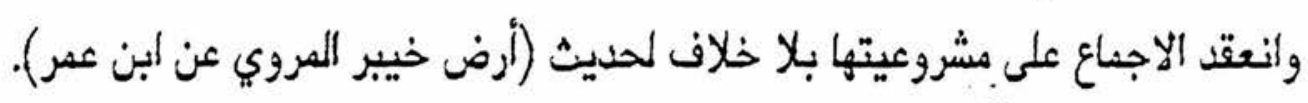

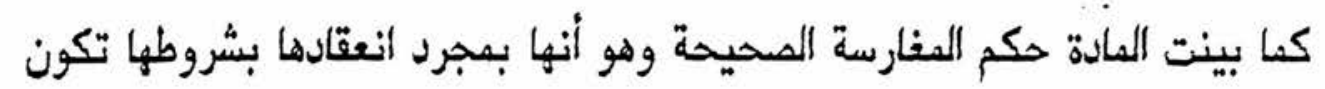

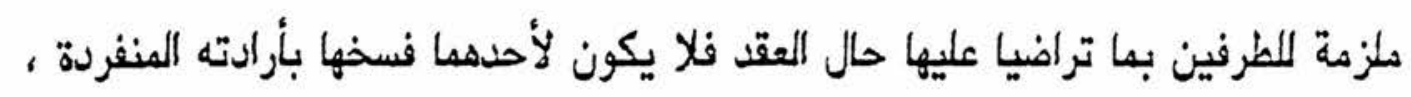

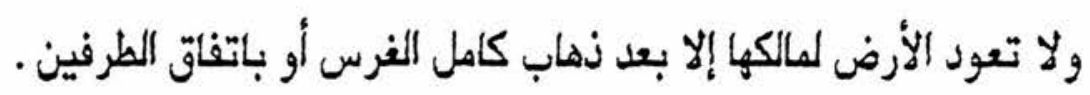


تبين حكم اختلال شرط أو أكثر من شروط صحة المغارسة المنصوص عليها في المادة السابقة كا تكون المدة أو الاجرة غير معلومة العقد لا يصح ، على أنه إنا كان الغرس قد تم فالمغوس للغارس وعليه أجرة هثل الأرض ، وإنا اتتق الطرفان على التفاسخ كان الخيار للغارس بين تفريغ الأرض بقلع الفروس واللرجوع على صاحب الأرض بالفرق بين قيمتها قائمة ليس لها حق البقاء وقيمتها مقلوعة وذلك لأنه إنما وضع الفراس فالأرض باذن مالكها، ومن ثم فالخيار إلثاني هو ابقاؤها في الأرض لمالكها بقيمتها قائمة ليس لها حق البقاء . SLO - Vro

تبين حكم ما وضع في الأرض بتعد من الغارس أو الباني أو نحوهما نحكمه حكم الفصب فيجب على الغارس أو الباني إزإلة غرسه أو بنائه ، وتعيض مالك الأرض عما أصابها

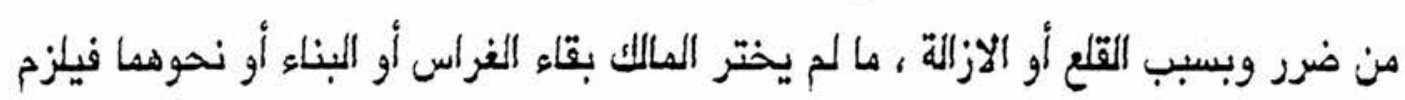
بقيمتها قائمة ليس لها حق البقاء وعلى الفارس أو الباني أجرة الأرض بما يقدره عدلان عن لئن المدة التي بقى فيها غراسه أو بذاؤه قبل اختيار المالك وكذا عليه أرش جناية ما أحدثه . سائة -

إتبطات المادة فنصت على أن ما لم يرن في شأنه نص يرجع فيه المى عرف الجهة ذلك

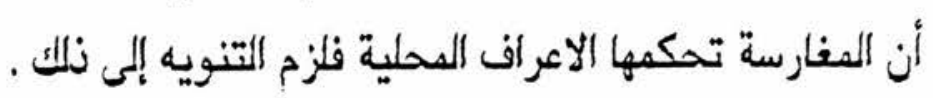




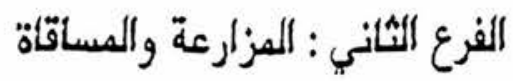

$$
\text { الأول المزارعة : }
$$

اختارت اللجنة ورجحت الرأي القائل بصحة المزارعة هدة هعلومة ولو كانت جزءا

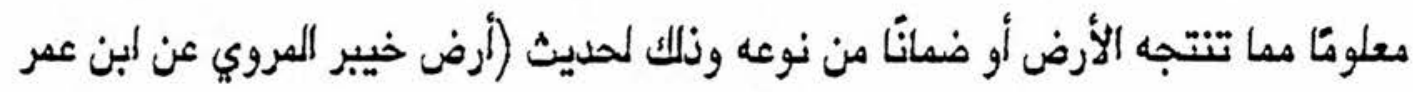

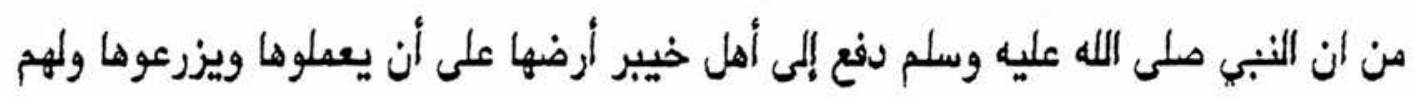

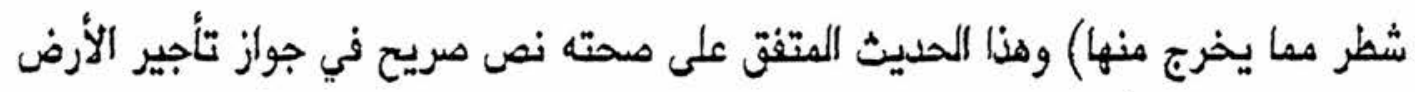

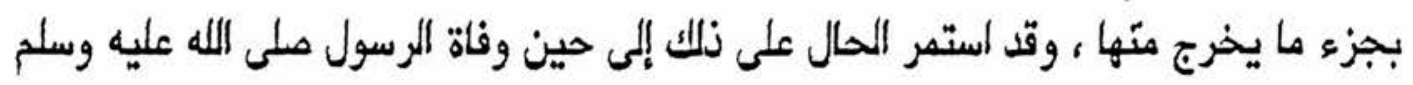

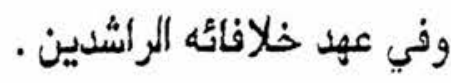
مائة - YTS

تبين حكم المزارعة الصحيحة التي توأفرت لها جميع شروط صحتها فأن العقد يكون

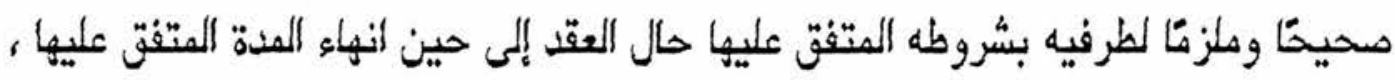

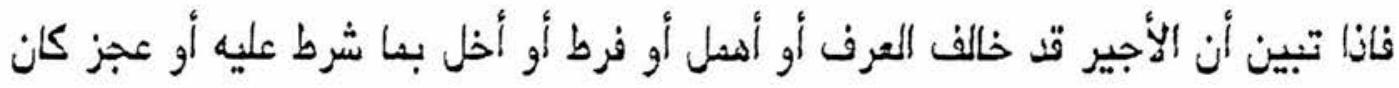

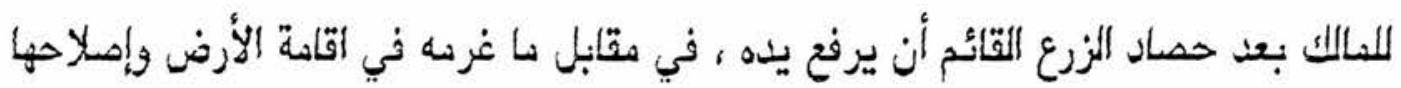

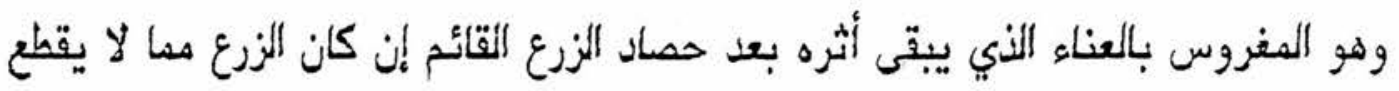
العناء عرنًا ، وإذا لم يكن الطرفان قد اتفقا على ددة دعينة فان المزارعة تكون صحيحة

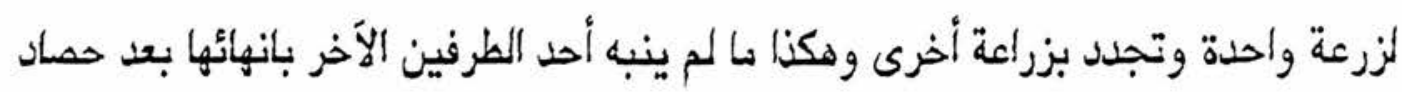
اللزرع القائم ، وإن يكون التنبيه قبل الحصاد بوقت كاف ، وقد استئت اللجنة البقول ونحوها هما يحصد أكثر من مرة فجعلت حكه للعرف . 
بينت المادة حكم المنوع من المزارعة المعروف بالمخابرة ، وهو أن يدفع مالك الأرض جزءا هنها إلمى أجير ليزرعه لحساب المالك في مقابل جزءا آخر يزرعه الأجير لحصاب نفسه ، نهذه النوع من المزارعة باطل الحديث الصحيح الذي رواه البخاري ومسلم عن البن عمر قوله (أنا كنا أكتر الأنصار حقلا(3) ، نكنا نكري الأرض على أن لنا هذه ولهم هذه ، فربما أخرجت لفرئ هذه ولم تخرج هذه فنهينا عن زلك). مادة - Y

نصت المادة صراحة على أنه ليس للمزارع أن يتنازل عن الأرض مدة الاجارة أو يؤجره

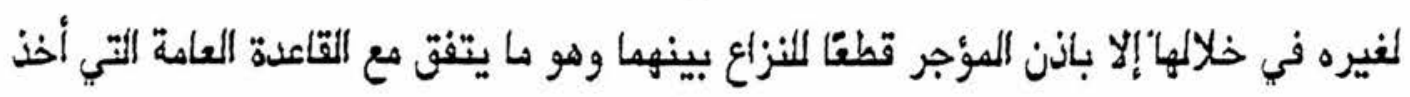
بها القانون . مائة - Y

تبين المادة حكم ترالك المزارع للأرض بعد أن حرثها وأصلحها ولكذه لم يزرعها فان

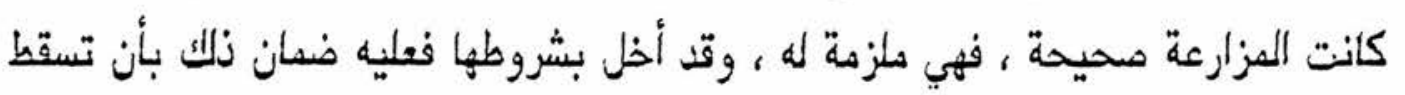

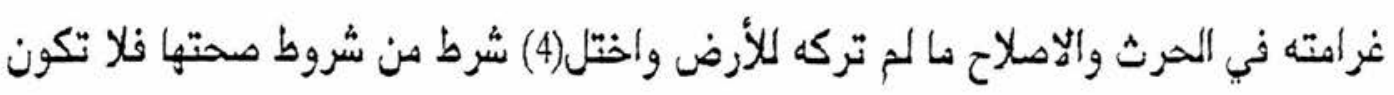

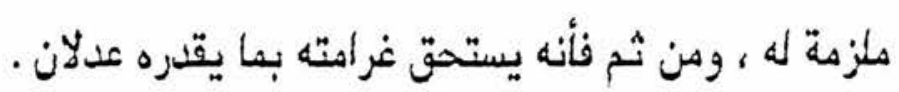

$$
\begin{aligned}
& \text { الثناني المساتقاة : } \\
& \text { مالة - YYY }
\end{aligned}
$$

المساتقاة بشروظها المنصوص عليها في المادة من حيث عمل المساتي ومدة المساتاة والأجرة ، هي اصلاح الغرس أو النزع وتنقيته وسقيه أورادا دعلومة بأجرة معلوهة ، ولو جزءا هما تنتجه الأرض ، وهي صحيحة ، وملزمة للطرفين ، ولا تفسخ إلا برضائهها لإهمال

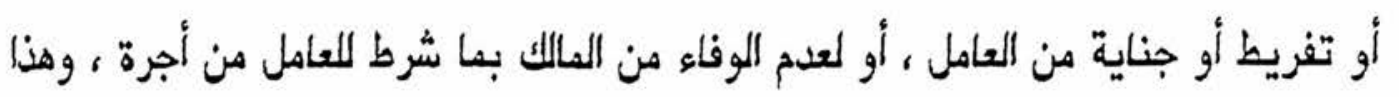




\section{متفق عليه لحديث أرض خيير المتقدم ذكره .}

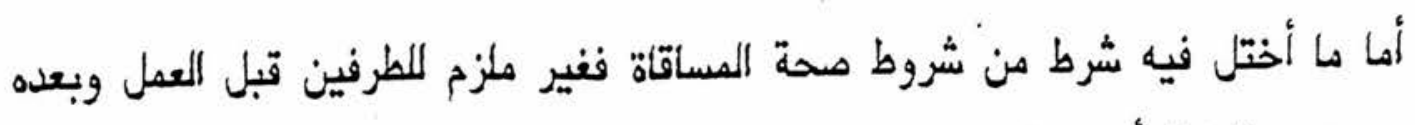

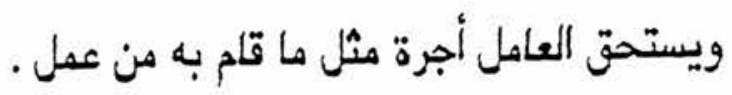
مائة - Y Y

تطعا اللنزأع نصت المادة صراحة على أنه لا يجوز للعامل أن يتنازل عن المساقةة لغيره

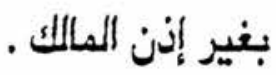

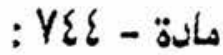

الأحكام المنسوص عليها في هذه المادة تشمل المزارعة والمساتاة وهي تبين حكم

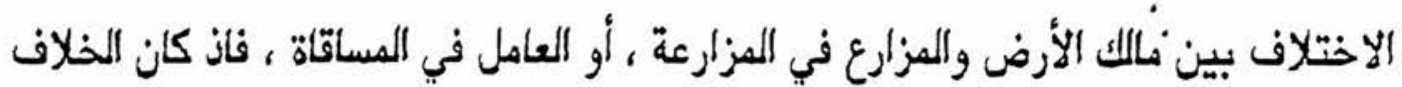

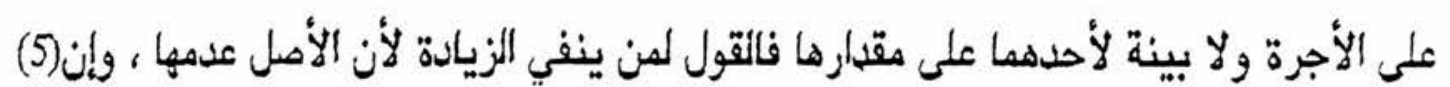

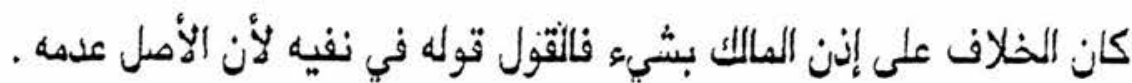

\section{Nores:}

(1) In the original text. $\dot{\partial}$ is printed, which makes no sense. Eor

(2) In the original in this second mention of eliall the final namzah is missing.

(3) In the original, the word is wrongly printed Lë

(4) In the orginal. the alif is missing in the word

(5) In the original, this word is wrongly spelt $\cup^{3}$. 


\section{APPENDIX 3 \\ ARABIC TEXTS OF THE YEMENI SHARECROPPING CONTRACTS \\ AND PLEAS REFERRED TO IN THIS THESIS}

(A) Three Contract Formats from Hadramawt

Source: the late 19th century Hadramī Ms. by Shaykh Muhammad bn

cAbdallāh bn Ahmad Bā Sawdān, published by R.B. Serjeant (1964

:61-62).

An English translation of these three contracts has been given in Chapter 8 (Section 8.32 above).

\section{(1) صيغة المساقاة}

فيكتب: المحد لله ، وبعد ، فقد ساق (1) (كذا) فلانٌ فلانّا على النخل المعروف بكذا ، مساقاة شرعية ، مدة سنة كاملة ، أولّها شهر كذا ، بناصفة الثمرة ؛ وعليه إصلاح النخل المذكور ، وتلقيحه ، وتنقية نهّره ، وإصلاح الأجاجين (2) ، وتنحية الحشيش ، وحفظ الثمر وجذازه وتجففه ؛ يفعل ذالك (3) بنفسه ، أو بنايبه (4) . (r)

ويقال لها المناصبة ؛ وهى دفع الأرض لمن يغرسها هن عنده ، والششجر بينهما بالسورِيَّة أو التفضيل . فيكتب : الحمد لله ، وبعد ، فقد أتثق فلان ونلان على أن يغرس فلان مكانًا ، أو ارض الفلانى . ثم يحلدها به حفرة بما شاء من أنواع النخل ، وعلى الفخيذ المُقالع ، والمؤَن ، والسقى ، والتنمية الى التعتيق بعرف الجهة ؛ وذالك فُخْذ النصف ، أو على المناصفة تخابرا على زاللك مخابرة ومفاخذة صحيحة شرعية . كان زالك بتاريخ يوم كذا هن عام كil . 


\section{(r)}

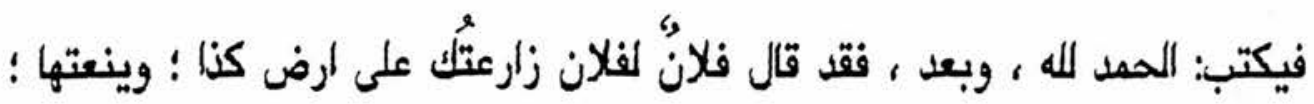

لتزرعها ، وعلّّ بذرها ، وعليك نصف ثمرتها ـ ومثله : عاملتلك على ارض كنا ، وعليك بذرها ، ولك نصف ثمرتها ، مزارعة ، أو مخابرة ، صحيحة صريحة شرعية ، جامعة الشروط المقتضية للصحّة المرعية ـ كان ذالك بتاريخ كنا فى عام كذا .

Notes:

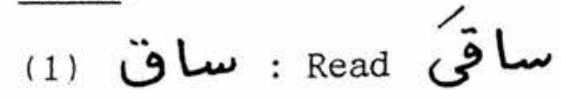

(2) الأأطين : Read : This term has been discussed in the text of the thesis (Chapter 8, Section 8.21).

(3) ذالك : الكل Read, as throughout.

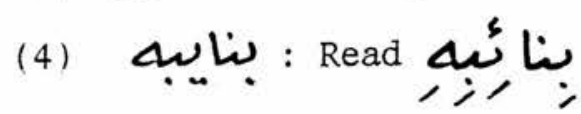


(B) Three Written contracts from al-cudayn

Source: the $A m \overline{7} n$ al-Mahall of al-cudayn

An English translation of these three contracts has been given in Chapter 8 (Section 8.33 above). The identified place-names are shown on the sketch map Figure 8.1 above.

al-cUdavn Contract No. 1

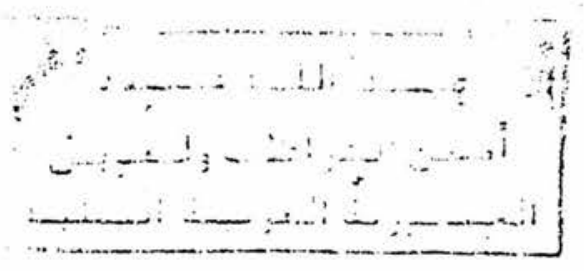

(ب)

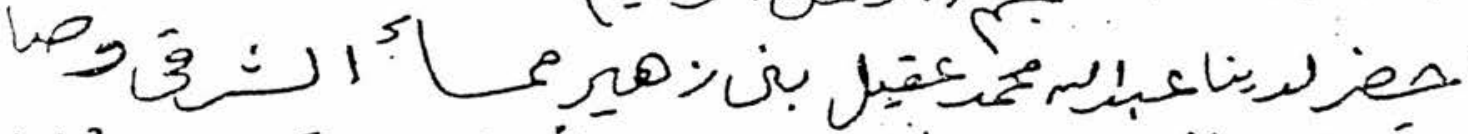

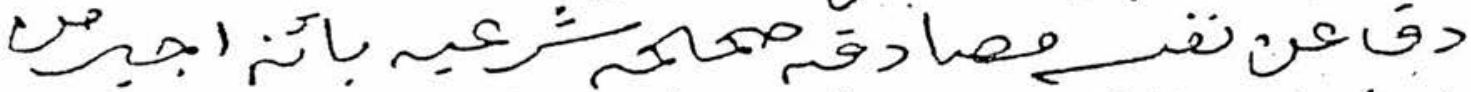
أles

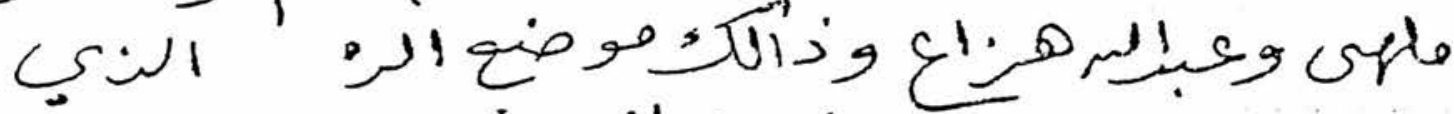

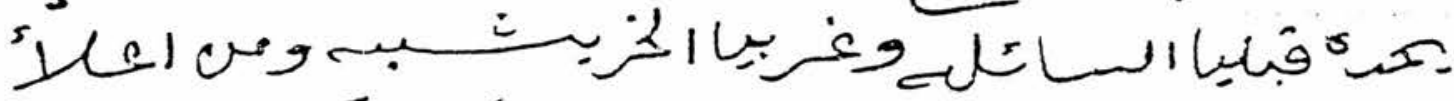

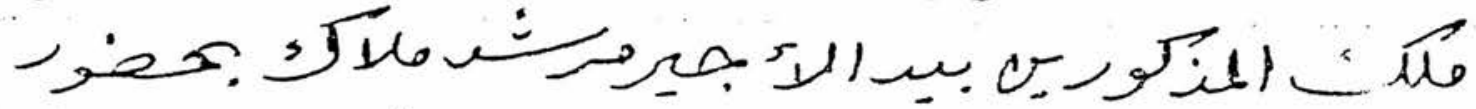
|'

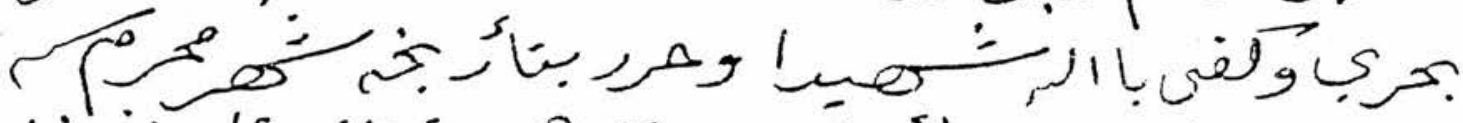

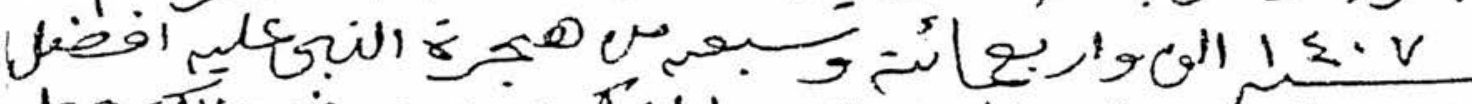

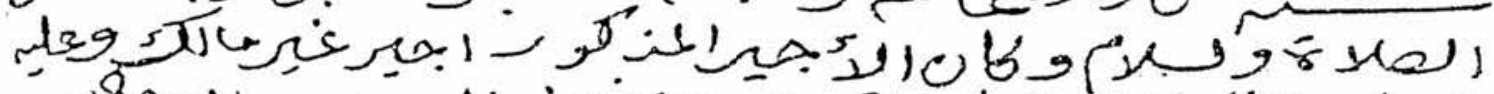

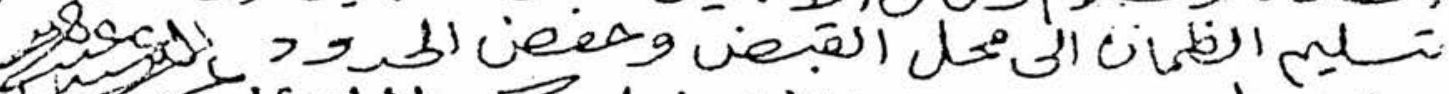
و 


\section{بســم اللله الرحمن الرحيم}

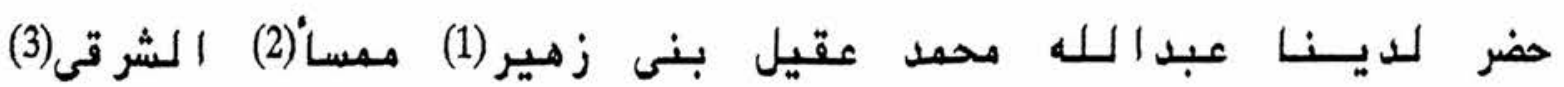
وصادق عن نفسه ممادقه صحيحه شرعيه بـانه اجير من الشيخ عبد

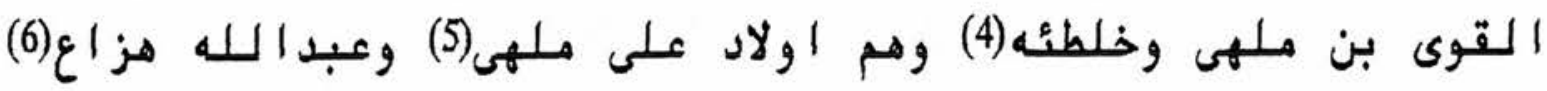

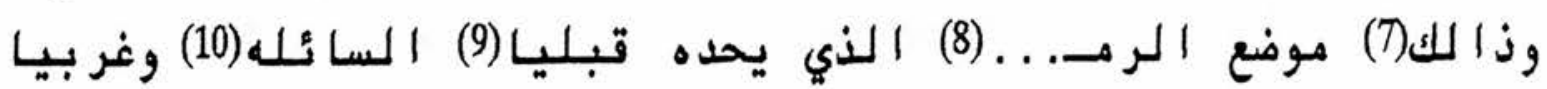
الخر يشبه(11) ومن اعلأ(12) مـلك الــنكورين بيد الأجير مرشد ملاك(13)

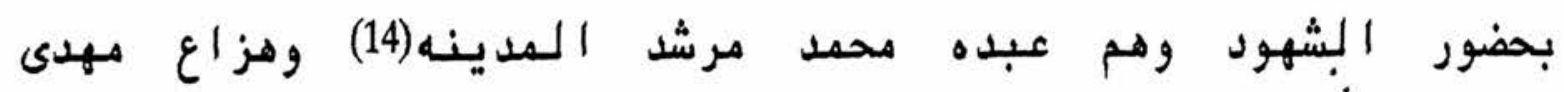
جبل بحري(15) وكفى بـا للـه(16) شهيدا وحرر(17) بتأريخه شهر محرم سنهل•عا الف واربعمائة وسبعه من هجرة النبى عليه افضل الصلاة ولسلام(18) وكان الأجير ألمذكور اجير غير مالك وعليه تسليم الظمان(19) اللى محل اللقبض وحفز(20) الحدود و تسليم المواءب(21) سا لف

$$
\begin{aligned}
& \text { البـلد كتب البراجى عفو ربـه } \\
& \text { [ توقيع الامين : ] عبدالله عبده عبدالله }
\end{aligned}
$$

Notes:

(1) Bani Zuhayr, the ${ }^{c} u z l a h$ on the south side of wädi cAnnah, opposite al-cUdayn. (An cuzlah is an administrative subdivision of a nähiyah ("district"), which in turn is a subdivision of a aadă' (approximately "governorate") or a 7 iwä, (roughly "province"). s cuzlah

(3) al-Sharqĩ: the name of the mamsā.

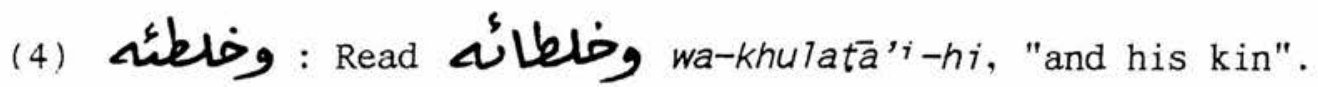

(5) ${ }^{\mathrm{A} A l} \bar{i} \mathrm{Mulh} \overline{\mathrm{I}}$ is known to be the brother of Shaykh ${ }^{\mathrm{c} A b d}$ al-Qawi.

(6) cAbdallāh Hazzāc is known to be the son of Shaykh ${ }^{c}$ Abd al-Qawĩ's sister. 
(7) SIJ : Read SU;, as throughout the three al-cUdayn documents.

(8) الر : the word is incomplete in the Ms., but it is known to be الرمّانح al-Rummānah, an area in the cuzlah of Banĩ Zuhayr, about $4 \mathrm{~km}$. downstream (i.e., west) of al-cudayn on the south bank of the Wâdi ${ }^{c}$ Annah.

(9) aibTiyan : northward, on the north side (the direction of the Qiblah).

(10) al-sä'ilah : the bed of the Wâdī cAnnah.

(11) al-Khurayshabah : the name of an area to the west of al-Rummānah.

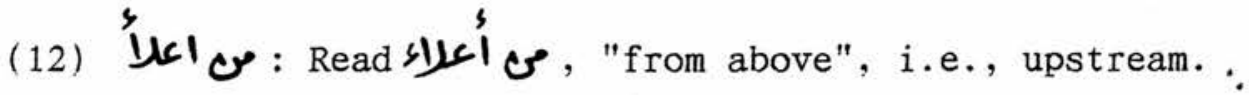

مرشف ملعك : this tenant's name is known in fact to be مرشد ملاك (13) (Murshid Mulayk).

(14) al-madinah : i.e., al-cUdayn.

(15) Jabal Bahrī, the name of the cuzlah on the north side of Wâdi cAnnah.

(16) بالله : باله :

(17) : קرر : passive hurrira.

والسلام Read : ولسمام : (18) :

(19) الألظاه: : Read النمان

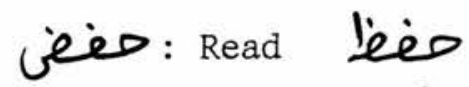
: Read : العواءب : al-sawä'ib which in general might be translated as "things which are fitting": cf. Lane 1862-93:1741c, entry sawäb, "a thing that is right"; Piamenta 1990-91 :289b sawīb "right, correct, true", though Piamenta (ibid.) also gives sä'ibah, pl. sawäyib, as meaning "compensation, indemnity". In the present context, al-sawä'ib were described by al-cUdayn farmers as "presents (hadāāa) given to the landowner when he comes to see the crops". 
al-cUdavn Contract No. 2

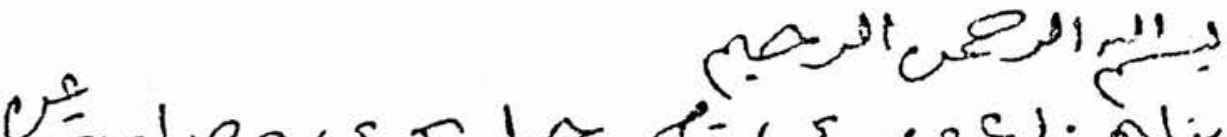

VEl

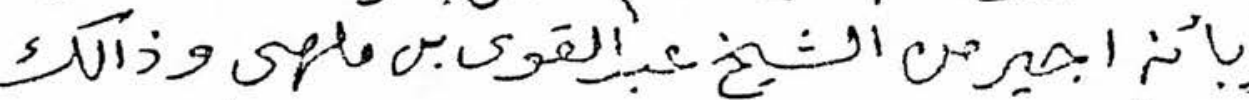

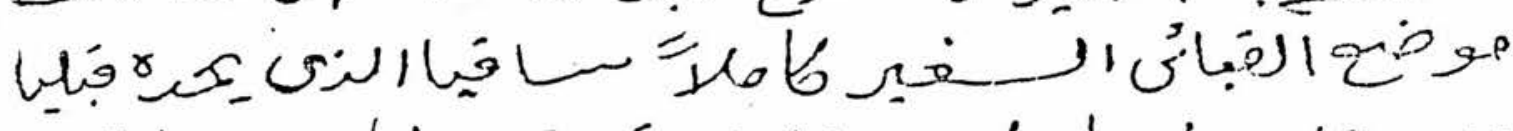

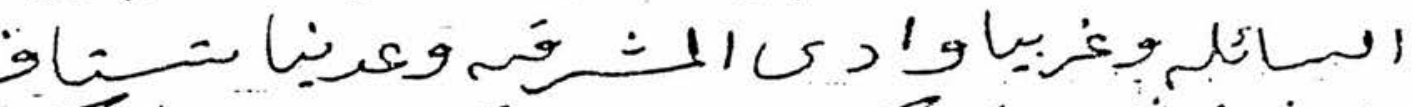
s وتح

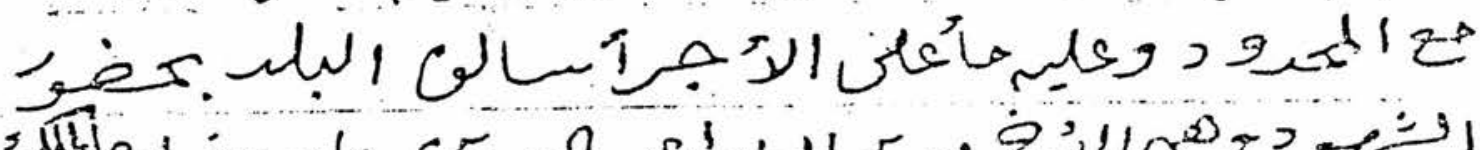

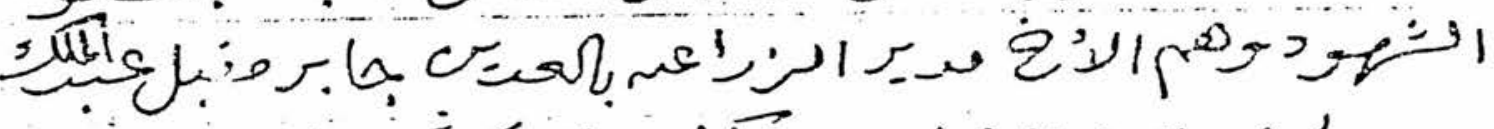

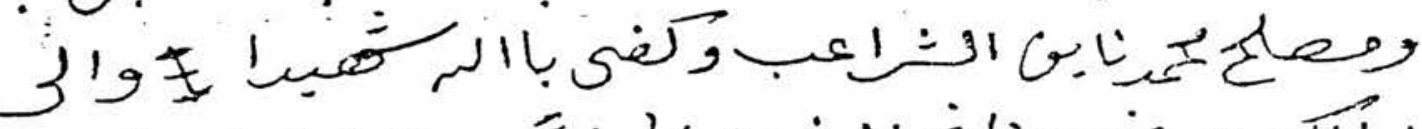

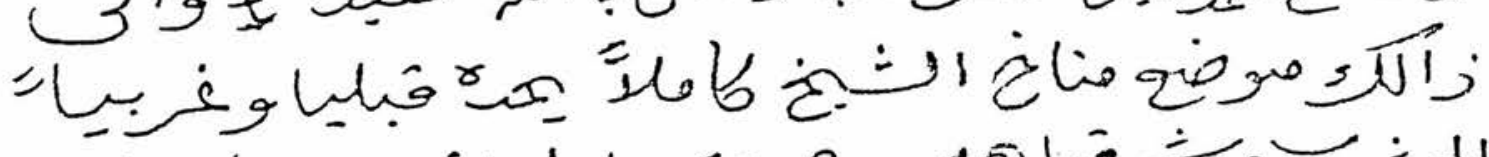

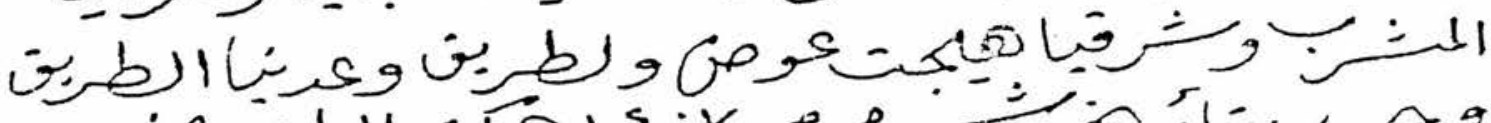
gهر

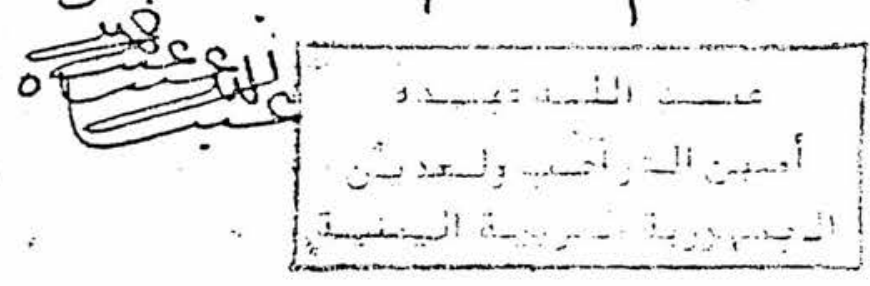




\section{بســم اللـه المرحمن البرحيم}

وحضر لـينـا هزاع مهدي قاسم(1) جبل بحرى(2) ومادق عن نفسه بـأنه اجير من الشيخ عبد القوى بن ملهى وزالك موضع اللقبائى

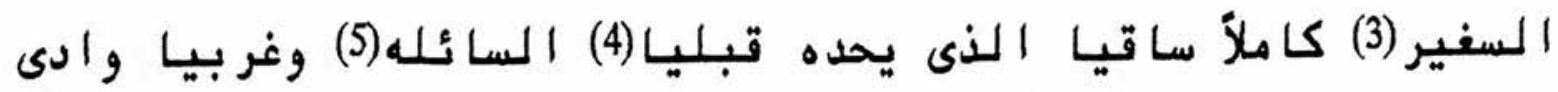

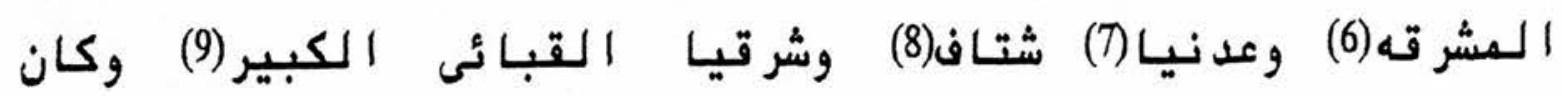
السـذكور اجير(10) غير مـالك وتسليم الفمان(11) الى محل اللقبض

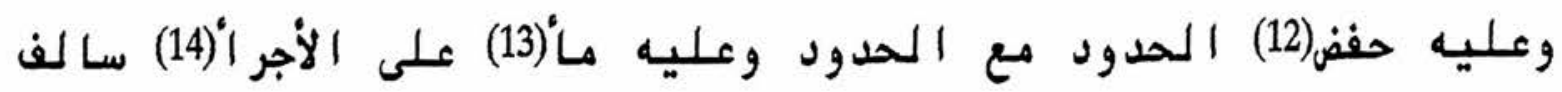

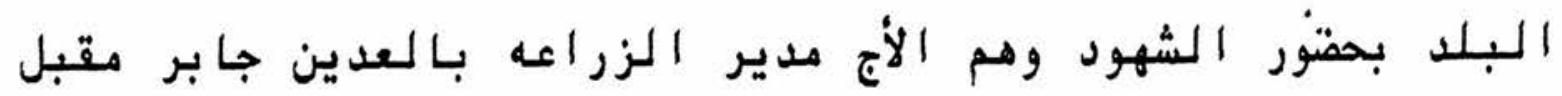

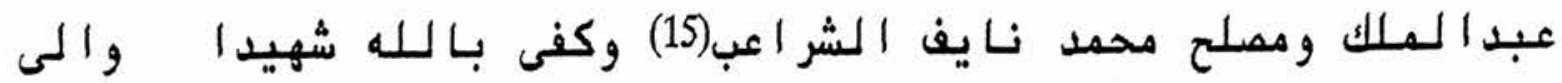
زالك موفع منـاخ الشيخ(16) كاملاً يحده قبليا(17) وغر بياً الـشرب(18)

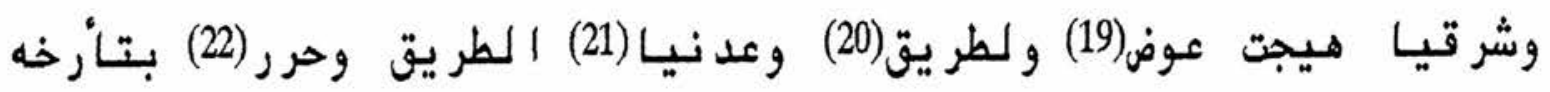

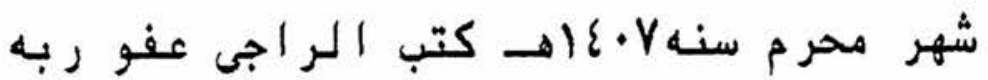
[ توقيع الامين : ] عبدالله عبده عبدالله

\section{Notes:}

(1) Hazzāc Mahdi ọasim : the same who acted as a witness in al-cUdayn Contract No. 1 .

(2) Jabal Bahri : see n.15 to al-cUdayn Contract No.1.

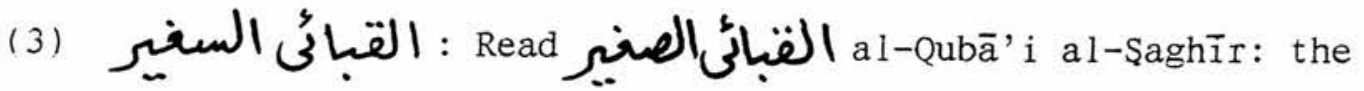
name of a tributary wā $\overline{7}$ which joins wâdī cAnnah downstream (i.e., west) of al-cudayn.

(4) gibTiyan : see n.9 to al-cUdayn Contract No.1.

(5) al-sä'ilah : see n.10 to al-cudayn Contract No.1.

(6) Wādī al-Musharraqah : a tributary wā $\overline{7}$ which enters Wādi cAnnah from the south, about $3 \mathrm{~km}$ downstream (i.e., west) of al-cUdayn. 
(7) direction of Aden).

(8) Shutāf : the name of a mabillah (an isolated house) on a low flat spur between Wādi ${ }^{c}$ Annah and Wadi al-Musharraqah (see n.6 above) near the point where they join.

(9) al-Qubā' $\bar{i}$ al-Kabīr : the name of a tributary wād $\overline{7}$ which joins Wādi cAnnah downstream (i.e., west) of al-cUdayn.

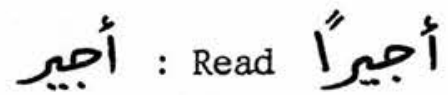

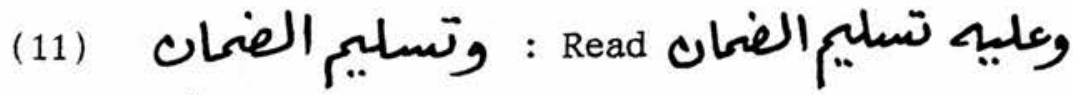

(12) : see n.20 to al-cudayn Contract No.1.

(13) L : Read L

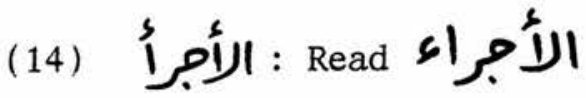

(15) al-Sharācib : the head village of an ${ }^{c} u z l a h$ adjoining al-cUdayn.

(16) Munākh al-Shaykh : the name of a locality.

(17) aibTiyan : see n.9 to al-cUdayn Contract No.1.

(18) al-mashrab : the course of the Wādī cAnnah.

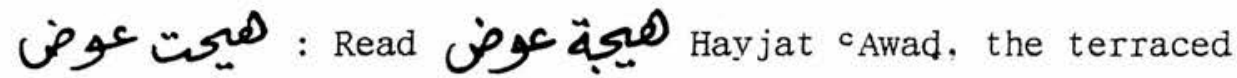
land belonging to ${ }^{\mathrm{c} A w a d}$ ( $\mathrm{cf}$. n.1 to al-cUdayn Contract No.3). (ط) : Read ; the road referred to is the track from al-cudayn westwards down the wādī cAnnah to Tihāmah. (21) cadan̄iyan : see n.7 above. קرر : see n.17 to al-cUdayn Contract No.1. 
al-cUdavn Contract No. 3

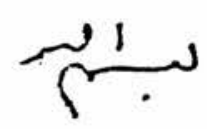

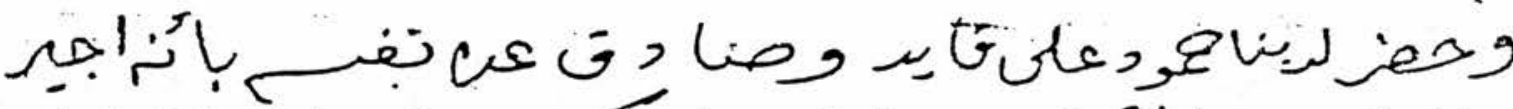

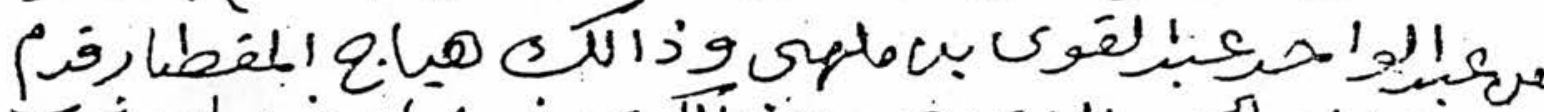
بـ

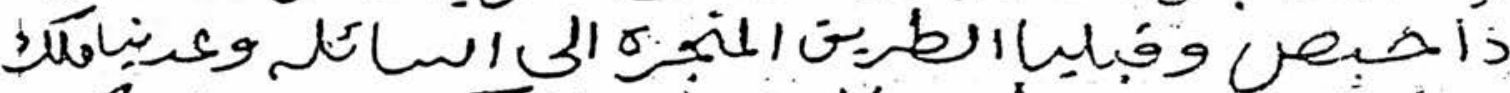
الت vén

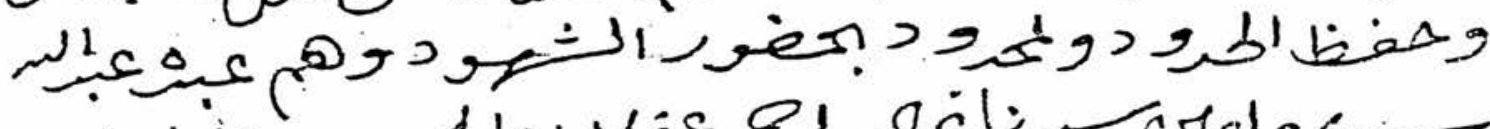

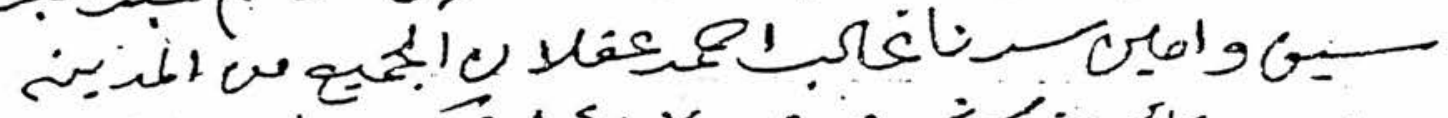

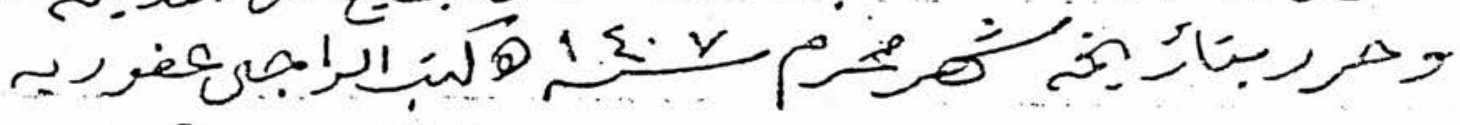
. 


\section{Edited Text of al-cudavn Contract No. 3}

\section{بســـ الله}

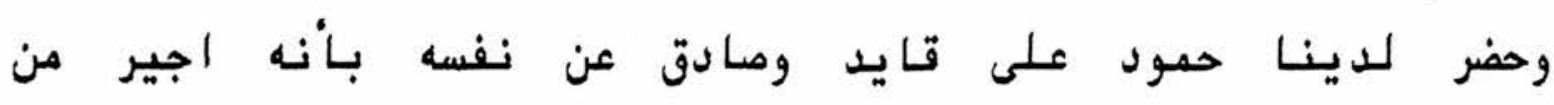
عبدالـواحد عبد اللقوى بن ملهى وذالك هياج الـقطار(1) قدم(2) بيت

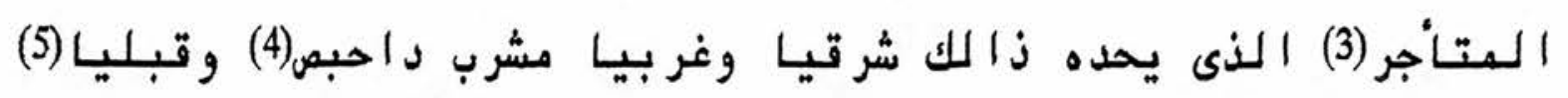

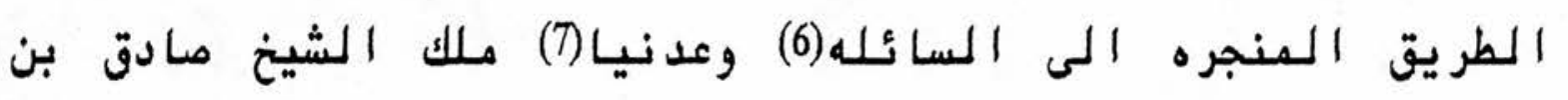
طه وكان الأجير المـكور اجير(8) غير مـالك وعليه الرعويه(9) التتامه و تسليم الظمان(10) الى محل القبض وحفظ الحدود ولهمدود(11)

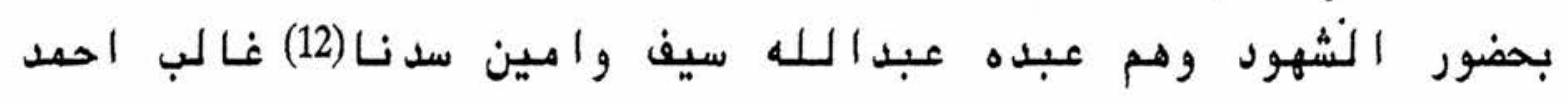

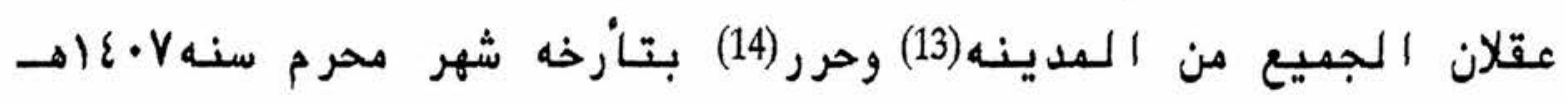

$$
\begin{aligned}
& \text { كتب الر اجى عفو ردبه } \\
& \text { [ توقيع الامين : ] عبدالـه عبده عبدالله }
\end{aligned}
$$

Notes:

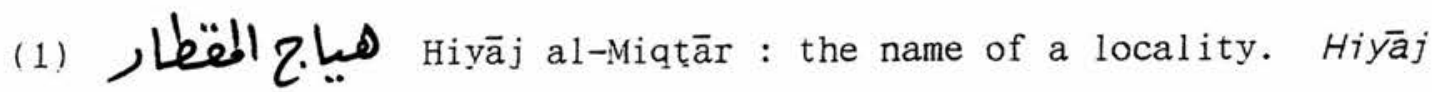

is the plural of hayjah (cf. n.19 to al-cUdayn Contract No.2 above) and means terraces, usually covered with orchards.

(2) qudm (= quddàm), in front of (cf. Piamenta 1990-91:389b).

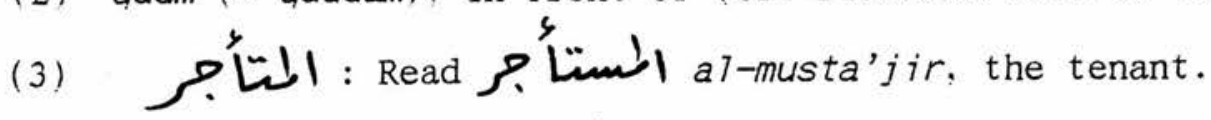

(4) seadad, the name of a locality.

(5) aibTiyan : see n.9 to al-cudayn Contract No.1.

(6) al-sä'ilah : see n.10 to al-cUdayn Contract No.1.

(7) cadan̄iyan: see n.7 to al-cudayn Contract No.2.

(8) aj7r : see n.10 to al-cudayn Contract No.2.

(9) al-racwīyah: = al-racy, custody, guardianship.

(10) : see n.19 to al-cudayn Contract No.1.

(11) 2 : Read 


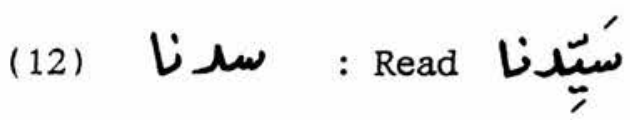

(13) a 1-madinah : see n.14 to al-cUdayn Contract No.1.

(14) : see n.17 to al-cudayn Contract No.1.

All three of the al-cudayn contracts bear the official stamp of the Aminn al-Maball of al-cUdayn:

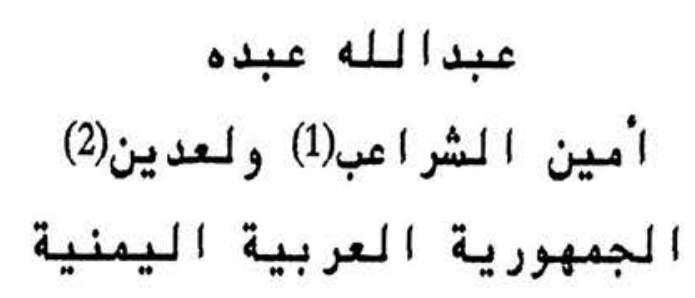

Notes:

(1) al-Sharācib : see n.15 to al-cudayn Contract No.2.

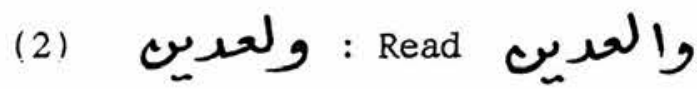


(C) A Model Musāqāh Plea, according to Bahraq

Source: extract from the $9 \mathrm{th} / 15$ th century Ms. by Muhammad bn cUmar bn Mubārak al-Himyarī al-Hadramī al-Shāficīi, known as

Bahraq, published by R.B. Serjeant (1955:11).

An English translation of this plea has been given in Chapter 8 (Section 8.42 above).

ويقول فى المساقاة : أدّى بأنّ فلانًا هذا ساقانى على غَيضته الفلانيّة ، بجميع ما فيها من

النخل ، على اختلاف أنواعها ، على أنّ على سقيَها وتعهُها ، وتسوية أنهارها ، وإصلاح حفرها وسواقيها ، وتلقيحها ، وحفظ ثمرها ، وجدادها (1) ، وغيره ممّا فيه صلاحها ـ ولى فى مقابلة عمل ذلك الثلث ، (مثيلا) ، من الثمرة الحاملة منها ؛ وقد امتنع من ذلك ، (أو) هرب ، (مثلاً) ، (أو) تصرّ فى عمله ، وأنبا مطالب له بالوفاء بما التزهه.

Note: جزاخ : Read (1) جداد 
(D) Two Model Musāaāh Pleas, according to the Bū Numayy Ms.

Source: the Ms. by the Sayyid Muhsin bn Jacfar bn ${ }^{c}$ Alawi $\mathrm{Bu}$

Numavy from al-Mukallā, published by R.B. Serjeant (1964:63).

An English translation of these pleas has been given in Chapter 8 (Section 8.42 above).

\section{باب المساقاة \\ (1) صورة دَعوى المالك (1) المساقاة}

أن يقول زيد : أدّعى بأنى ساقيت عمرًا هذا على البستان الفلانى بجميع ها فيه هن النخل على اختلاف انواعها ، على أن عليه سقيها وتعهدها وتسوية سواقيها وإملاح الحفر التى فى أثناء الموأقى وتلقيحها وحفظ ثمرها وقطعها وغير ذلك مما فيه صلاحها ، وله فى مقابلة عمله الثلث من الثمرة الحاصلة منها ، وقد امتنع من ذلك ، أو هرب ، أو قصر فى عمله ، وانا مطالبه بالوفاء بما التزهه من العمل ، ذهره ، أيها الحاكم ، بوفلو ذلك . (r) صورة دعوى العامل بمقابلة عمله فى المساقاة

أن يقول عمرو : أدعى ان زيدً ساقانى على البستان الفلانى بجنيع ما فيه من النخل على اختلاف انوأعها ، على أن على سقيها وتعهدها وتسوية سواتيها وإصلاح حفرها وتلقيحها وحفظ ثمرها وقطعه وغير ذلك معا فيه ملاحها ، ولى فى مقابلة عملى الثلث من الثمرة الحاصلة هنها ، وانا هطالب له بما شرط من الثهرة حالاً، ، وهو يلزهه وقد امتنع ذلك ،

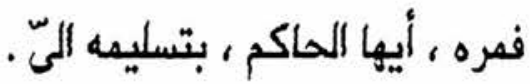

Note: (1) Insert 


\section{APPENDIX 4 \\ ARABIC TEXT AND ENGLISH TRANSLATION \\ OF THE BAB AL-MUSAQAH \\ FROM THE YEMENI MS. FATAWA IBN JACMAN}

These fatwās have been summarised and discussed in Chapter 8 (Section 8.5) of the thesis.

(A) Photocopy of the Manuscript .

(1) Colophon of title page (at about half the scale of the original)

The acid of the ink has unfortunately eaten into the paper, making much of the inscription illegible.

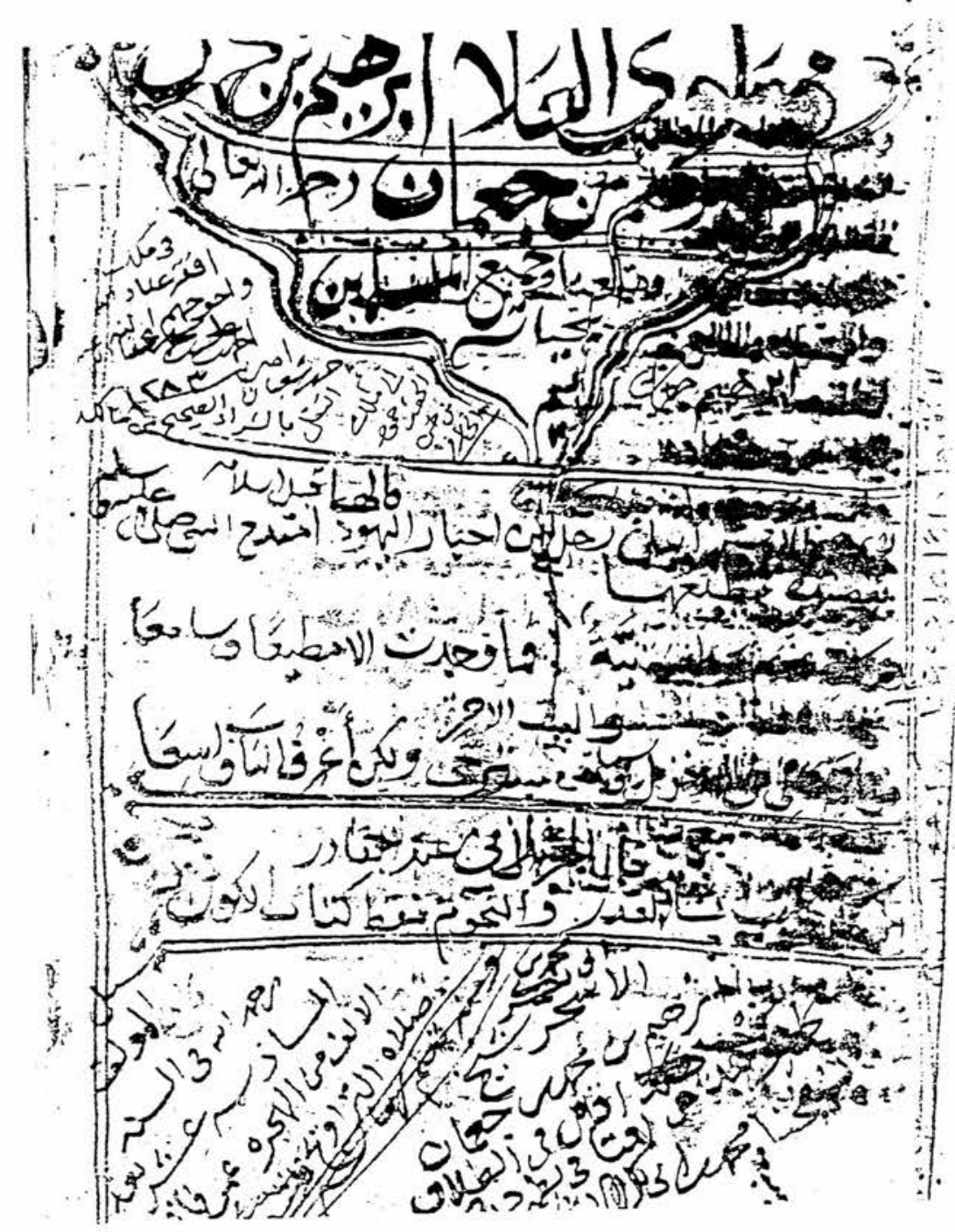


(2) The Bàb al-Musāaāh (pp.178b - 180a of the bound Ms. at approximately $90 \%$ of the scale of the original)

p. $178 \mathrm{~b}$ :

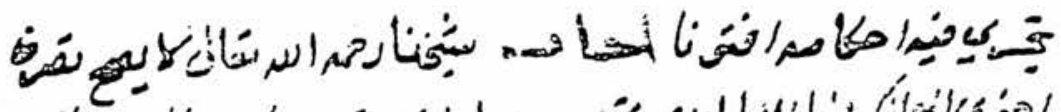

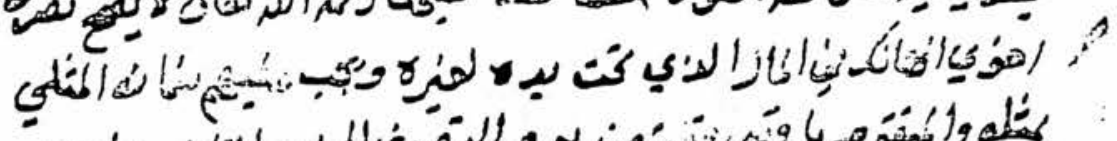

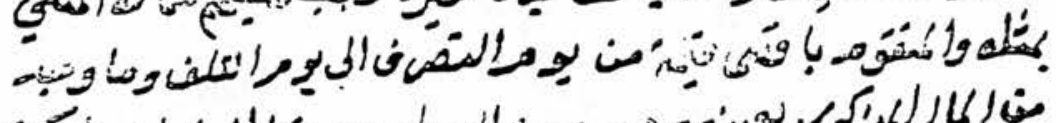

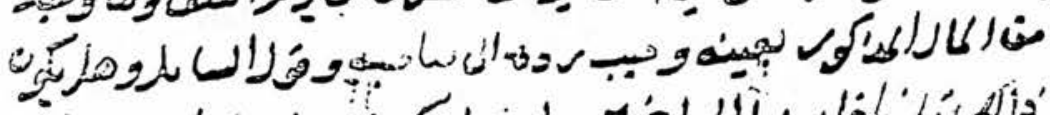

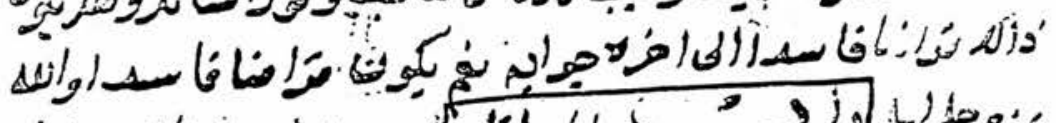

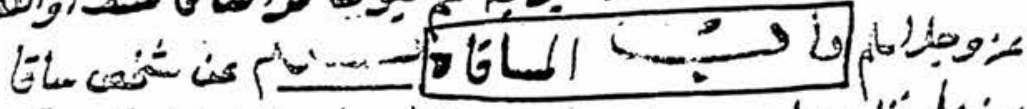

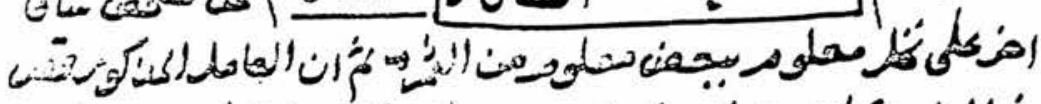

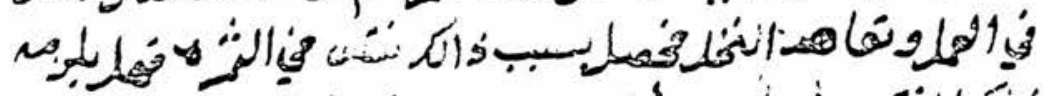

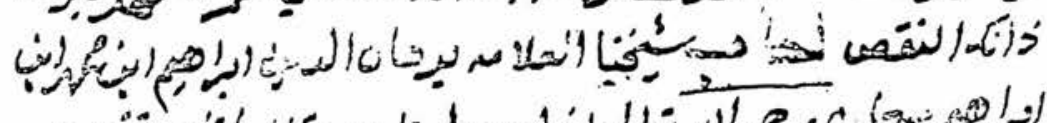

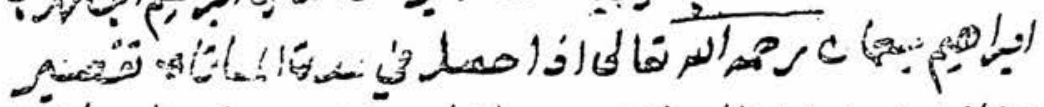

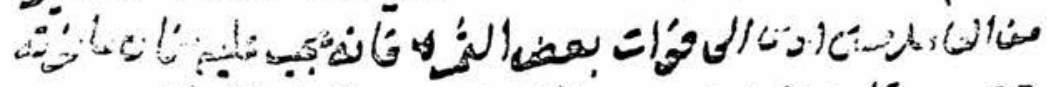

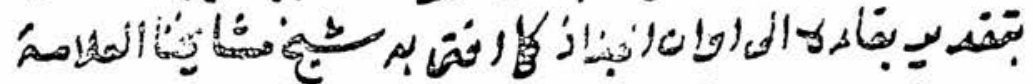

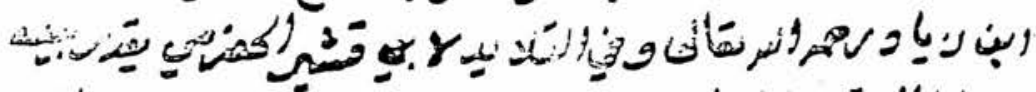

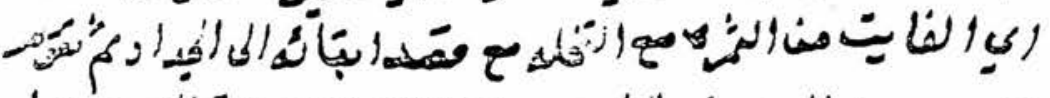
هو

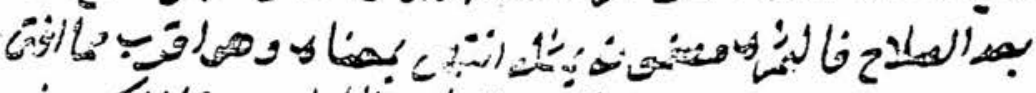

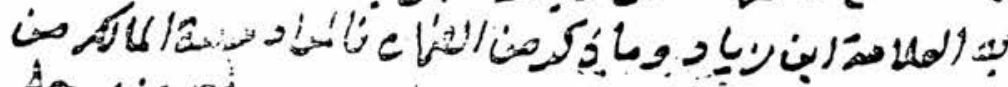

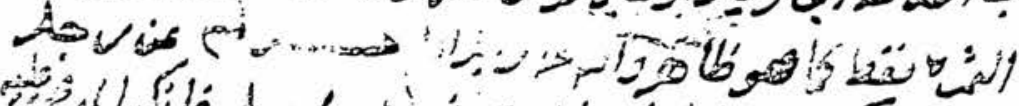

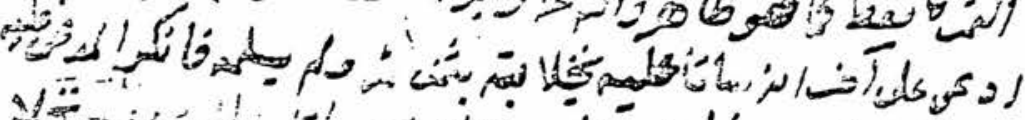

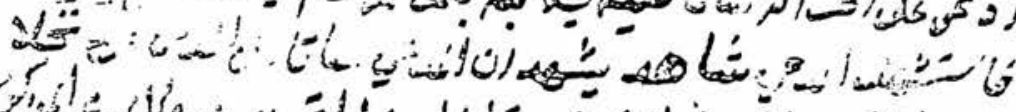

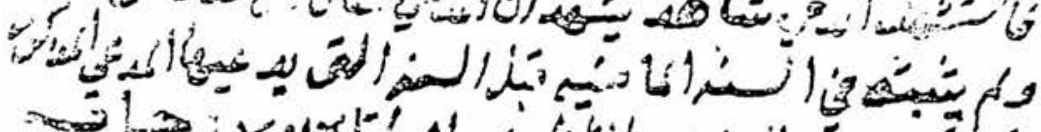
و

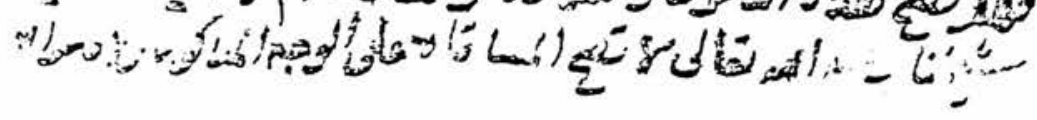




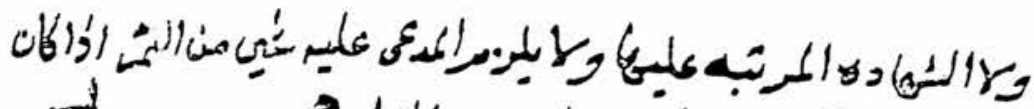

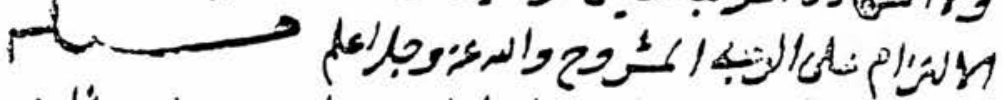

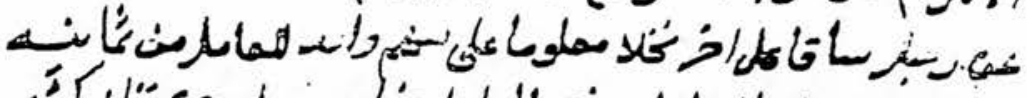

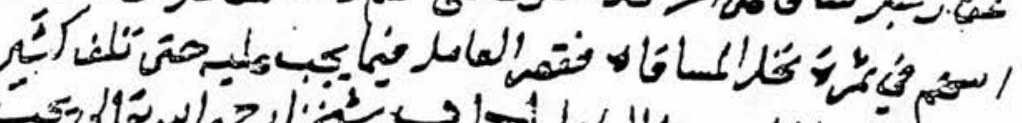

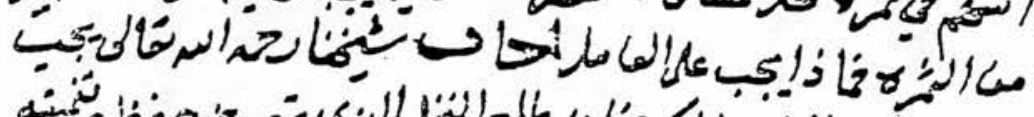

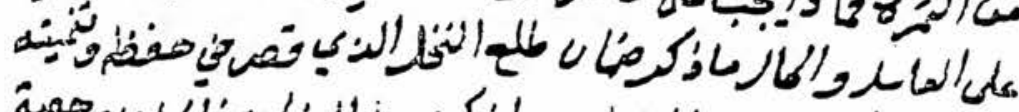

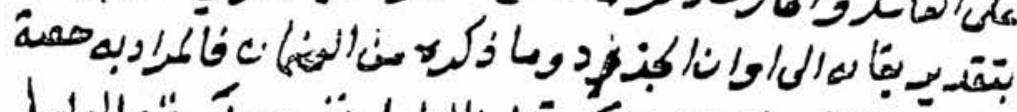

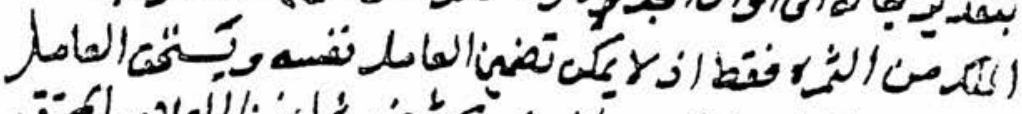

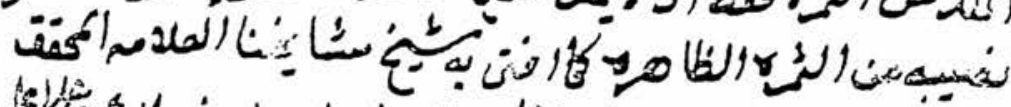

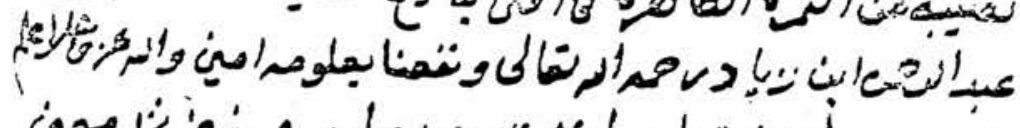

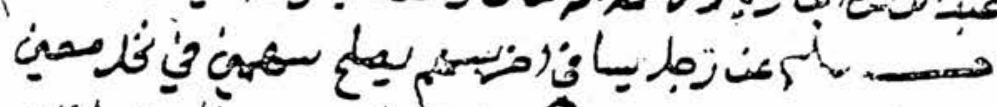

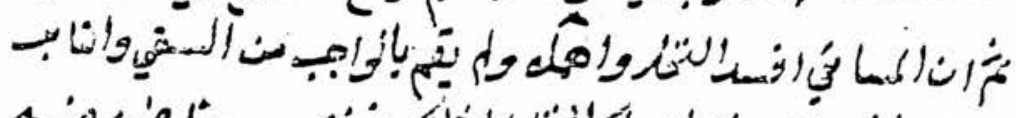

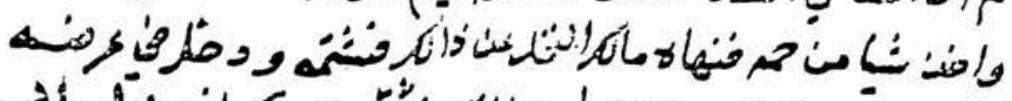

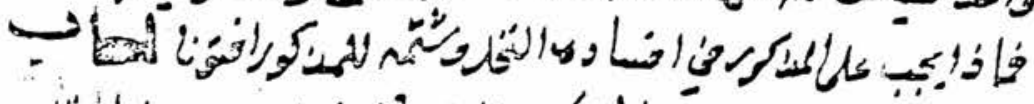

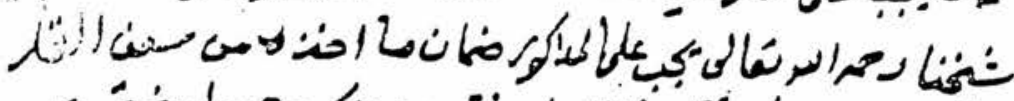

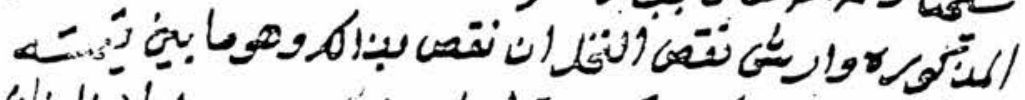

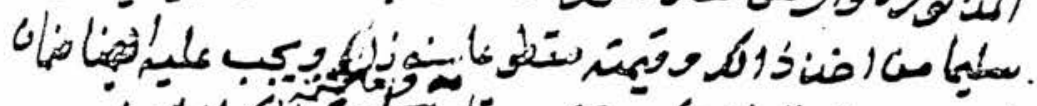

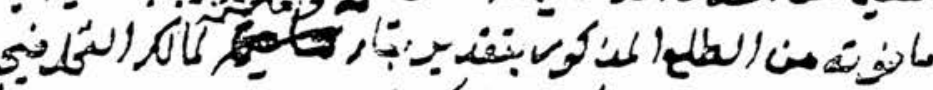

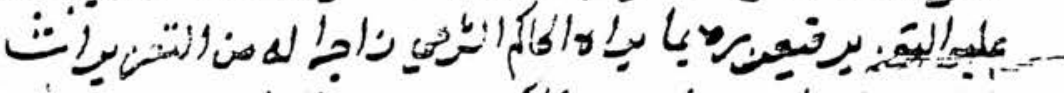

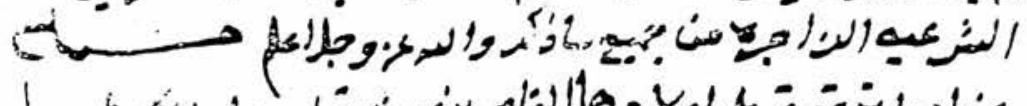

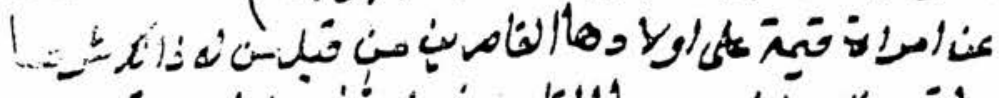

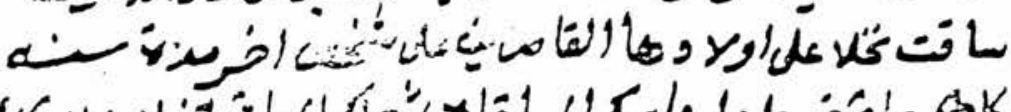

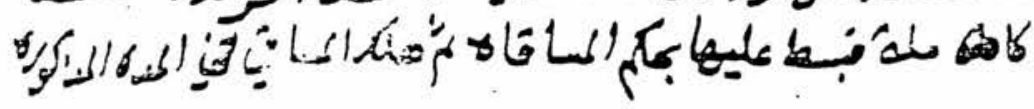




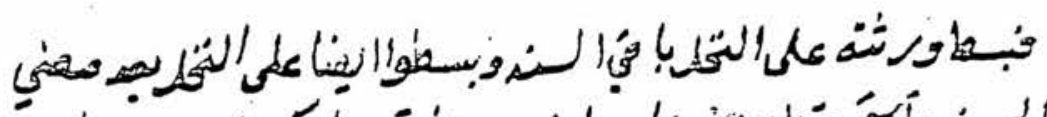

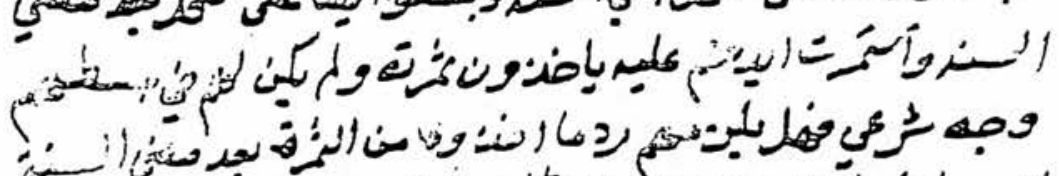

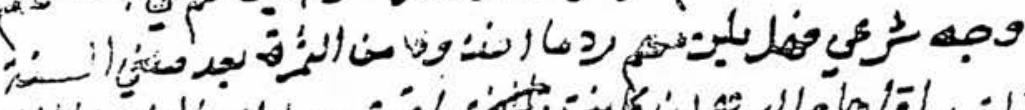

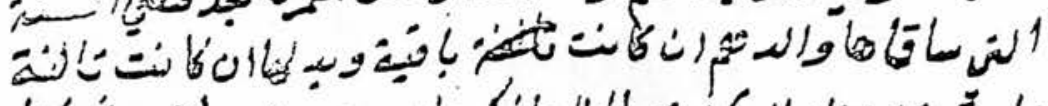

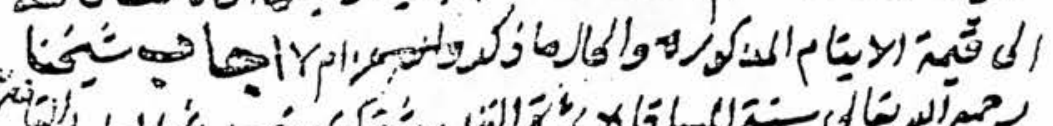

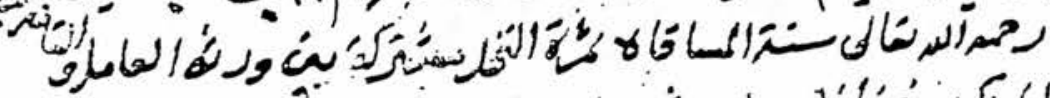

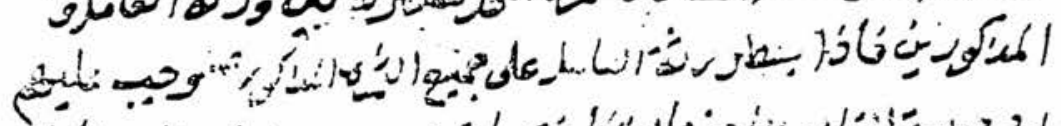
رد

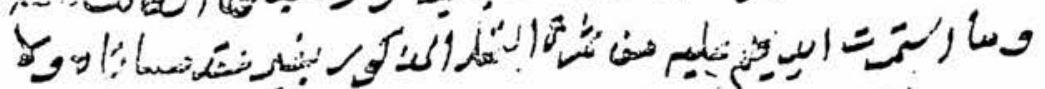

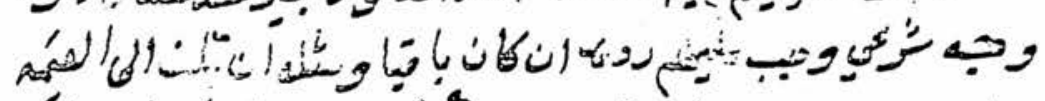

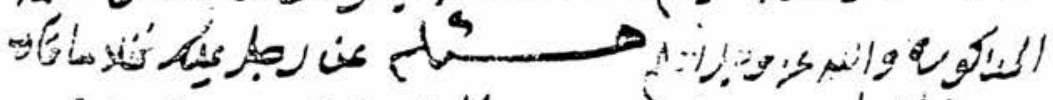

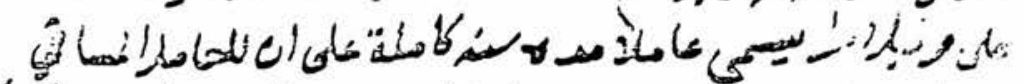

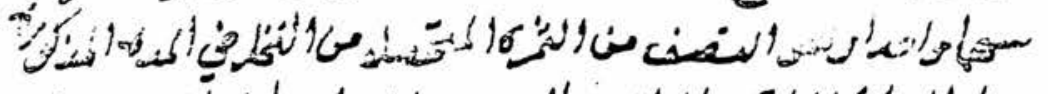

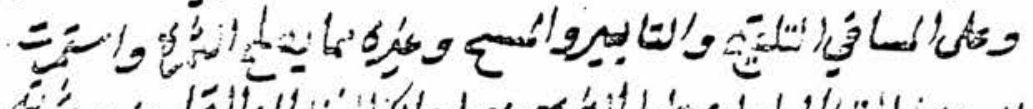

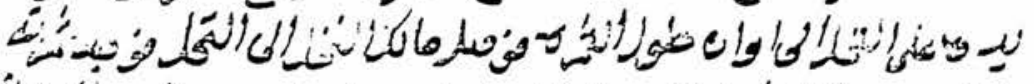

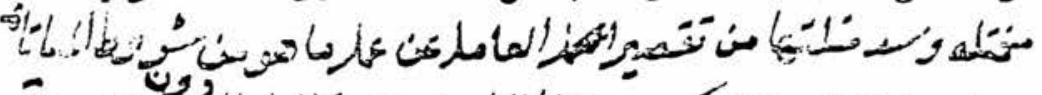

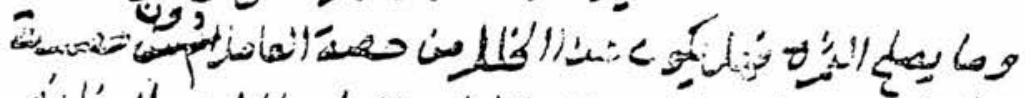

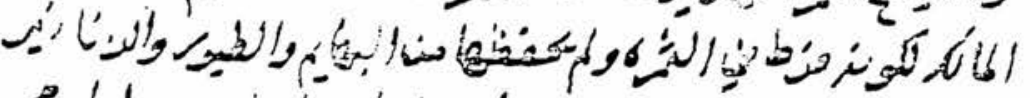

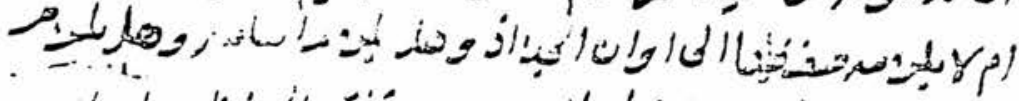
:

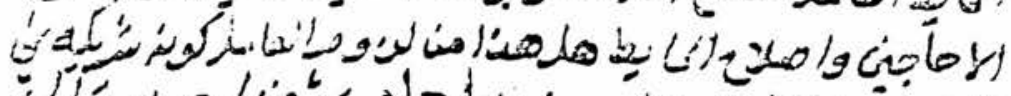
المتهن

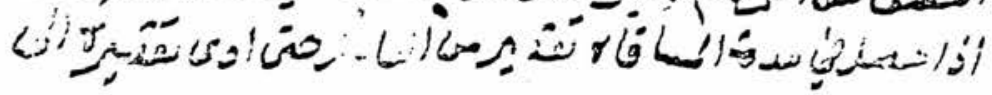




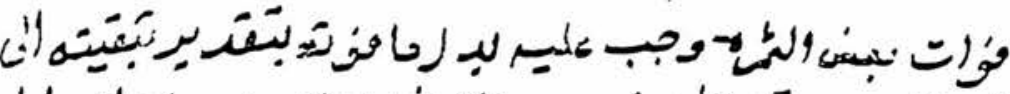

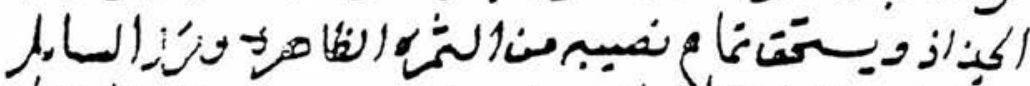

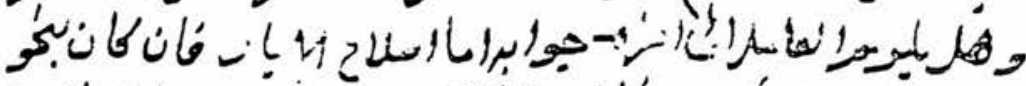

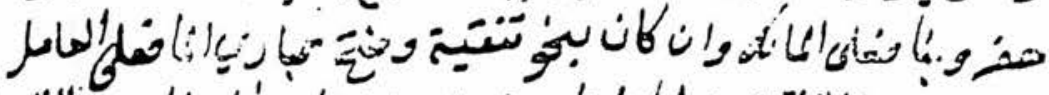

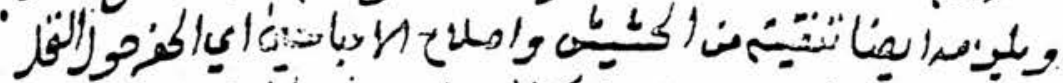

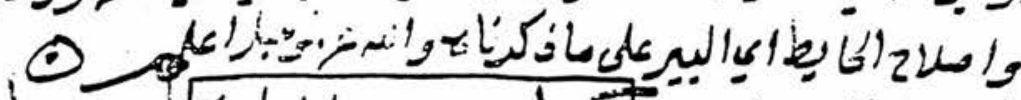
-

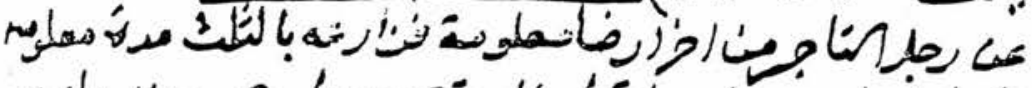

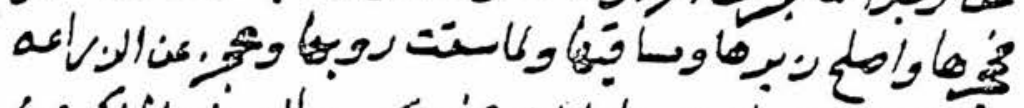

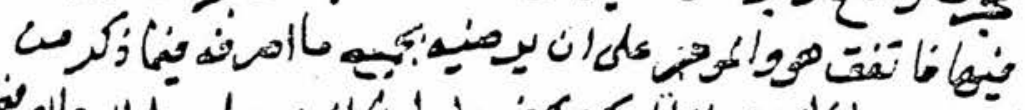

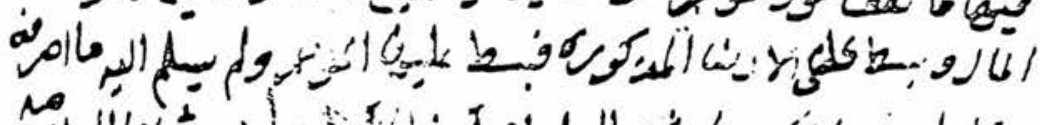

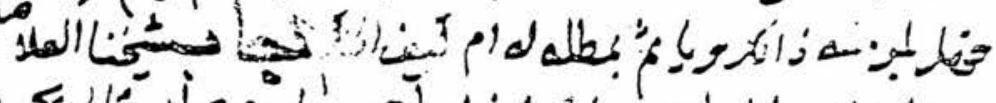

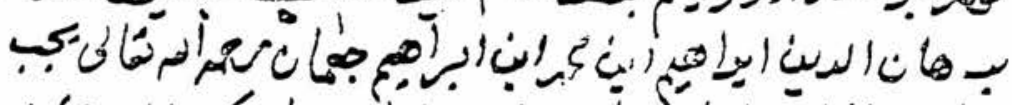

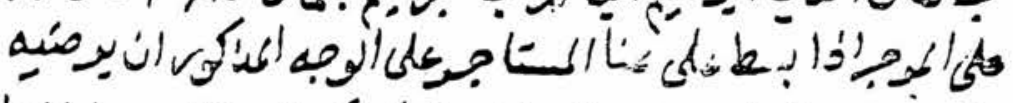

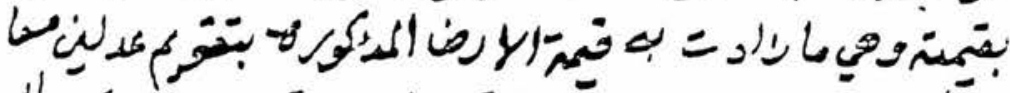

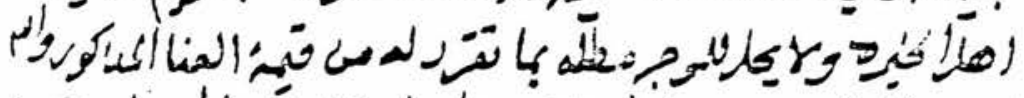

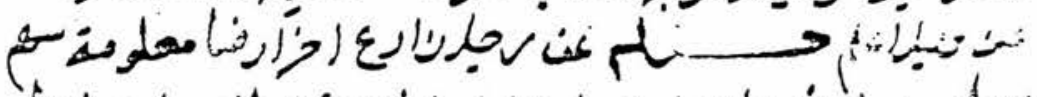

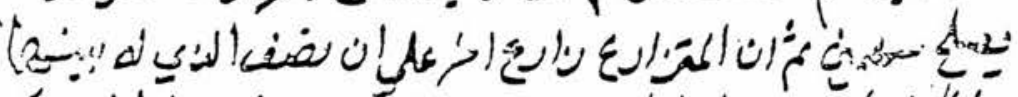

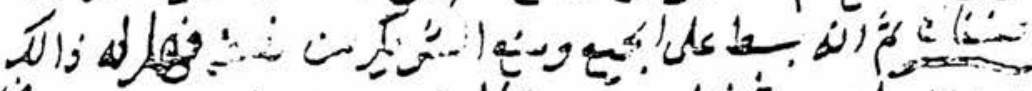

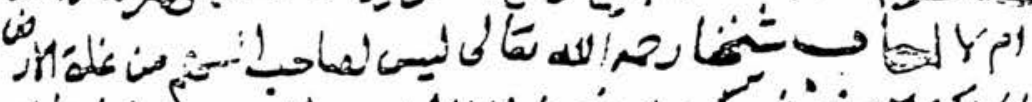

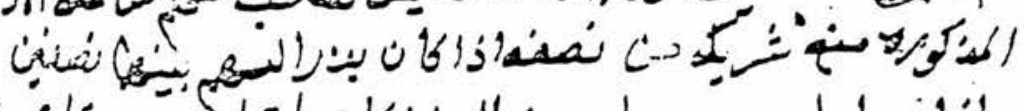

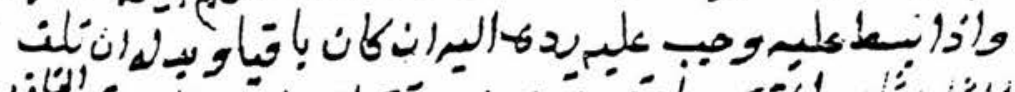

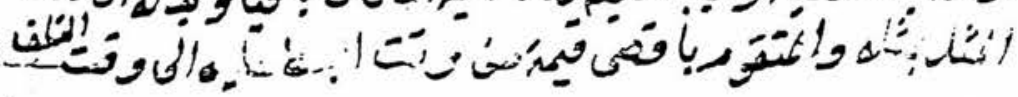


(B) The Edited Text

The numbering of the fatwās 1 to 6 is editorial. They are not numbered or otherwise identified in the Ms.

\section{باب المساقاه

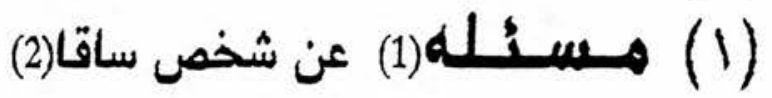

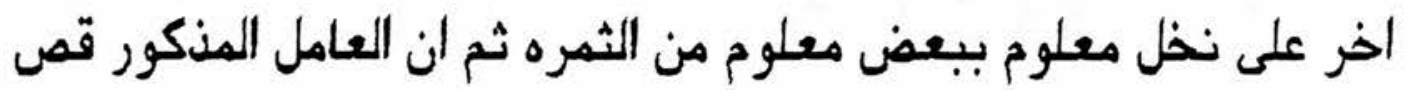

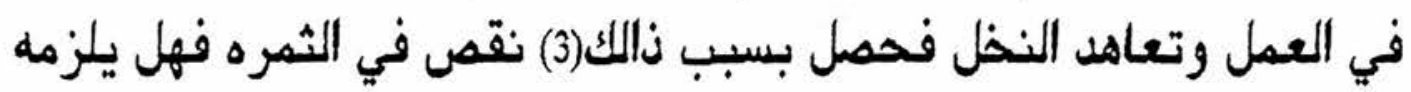

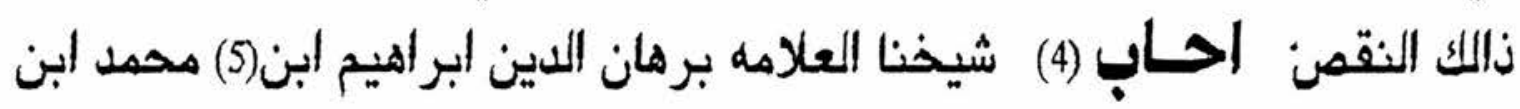

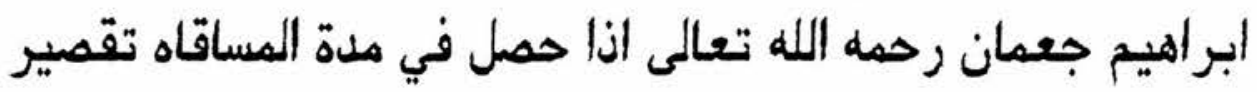

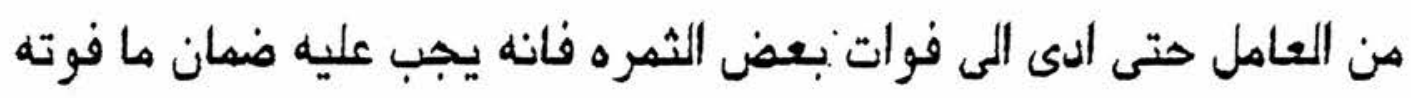

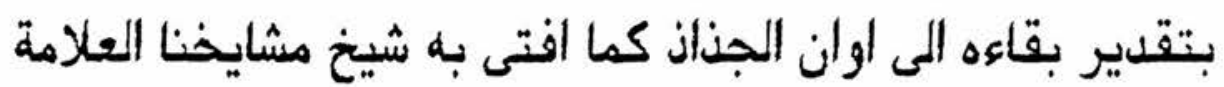

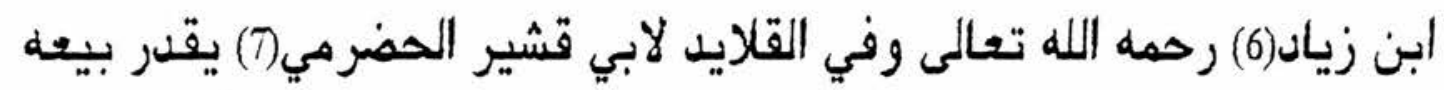

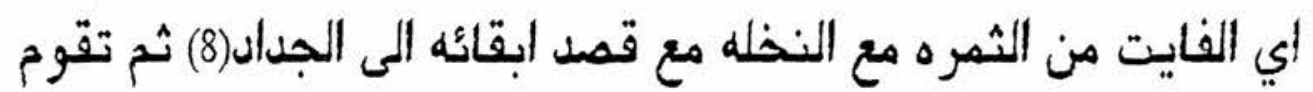

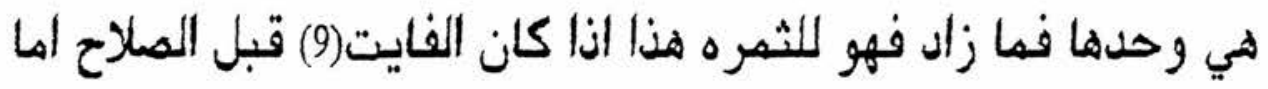

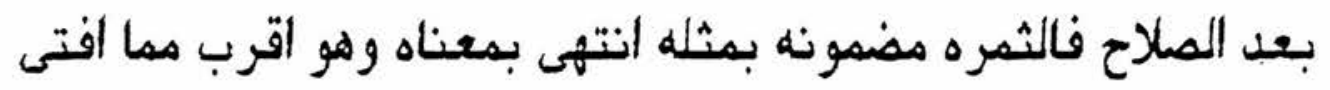

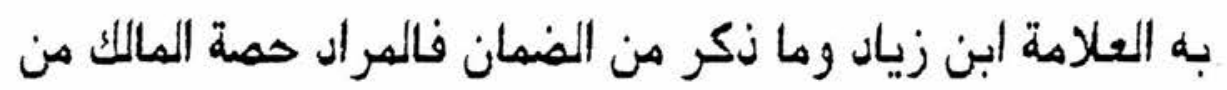

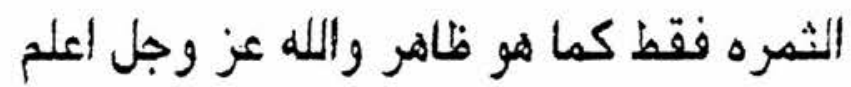




\section{(T) مسلسـله عن رجل}

ادعى على أخر انه ساقا عليه نخيلا بتة بثمن ثمر ولم يسلمه فانكر المدعى عليه

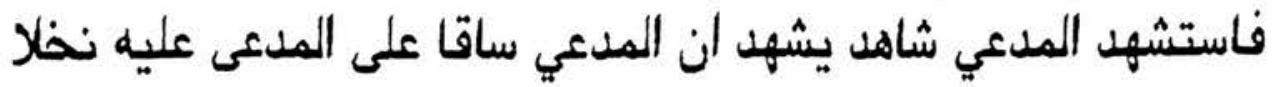

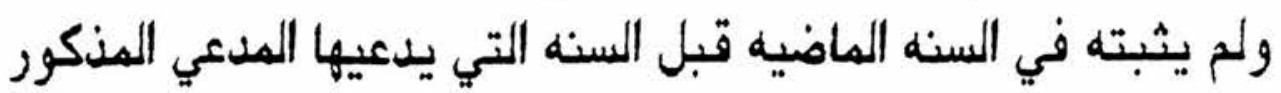

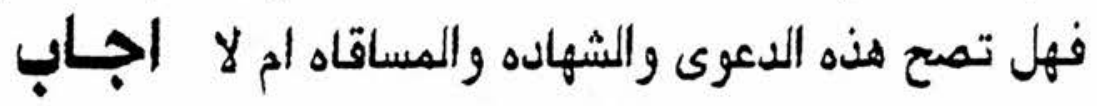

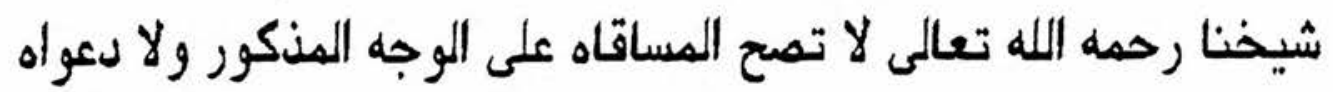

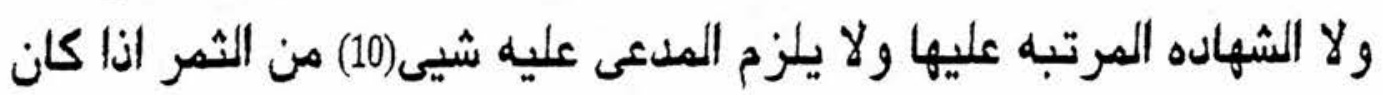
الالتزام على الوجه المشروح والله عز وجل أعلم

\section{هسبستبله}

عن رجل ساتا على اخر نخلا معلْوما على سهم واحد للعامل من ثمانيه

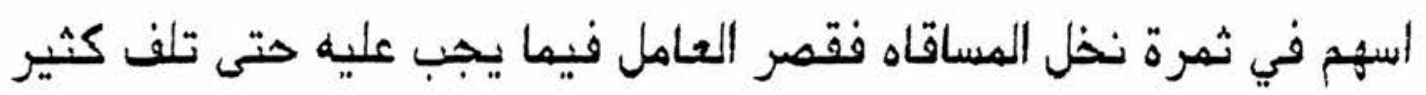

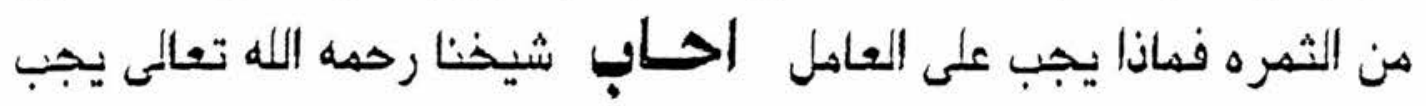
على العامل والحال ما ذكر ضمان طلع النخل الذي قصر في حفظه وتنهيته

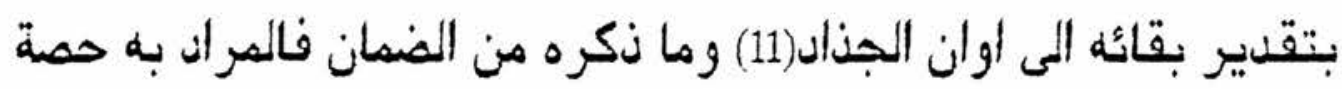

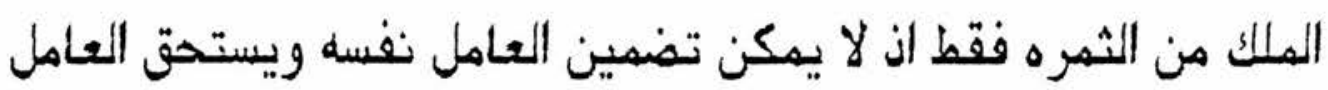

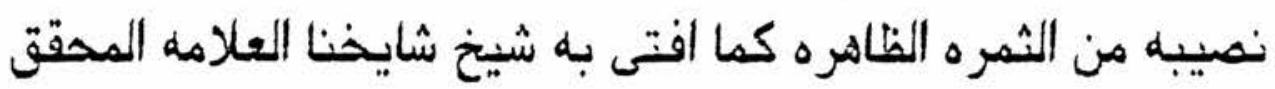

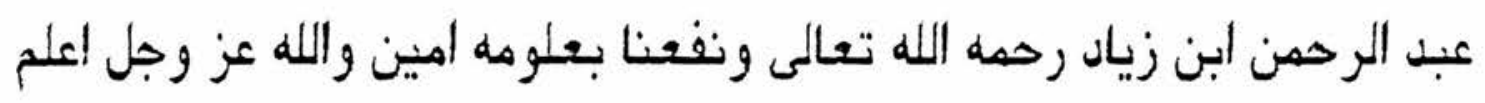

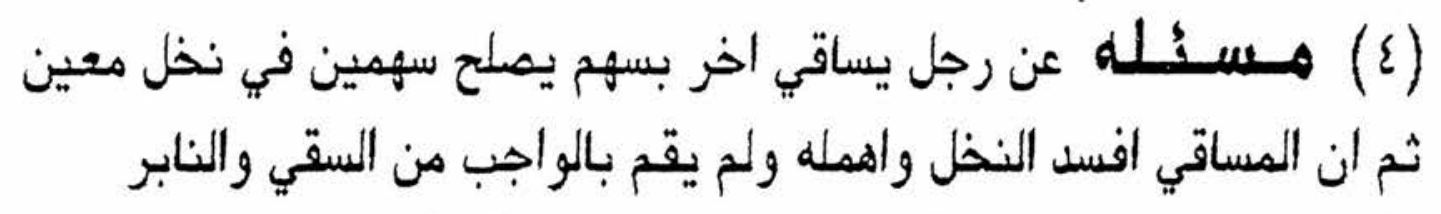

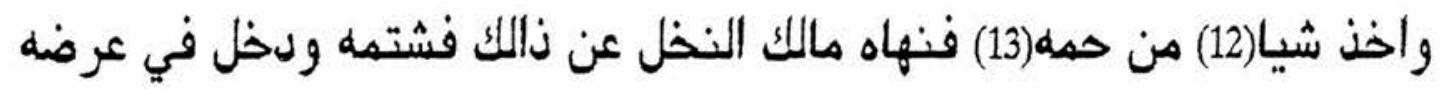




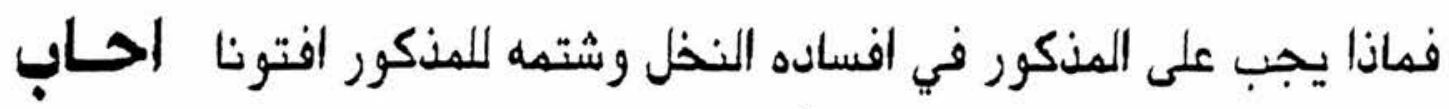
شيخنا رحصه الله تعالى يجب على المذكور ضمان اخذه من سعف النخل

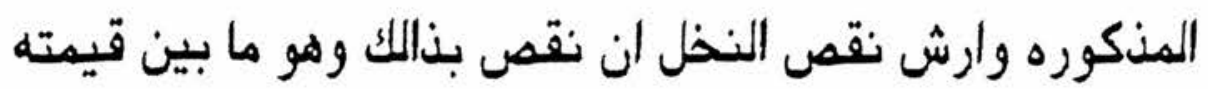

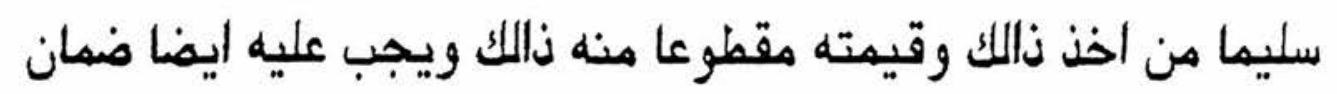

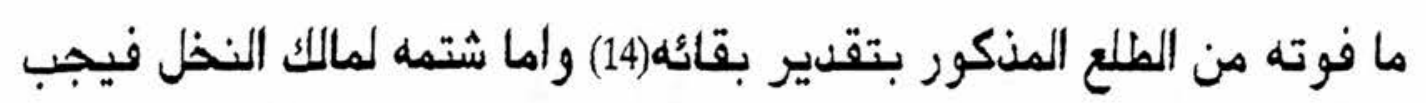

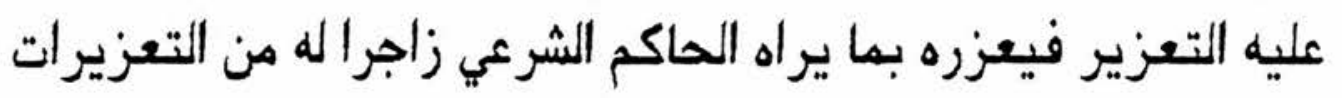

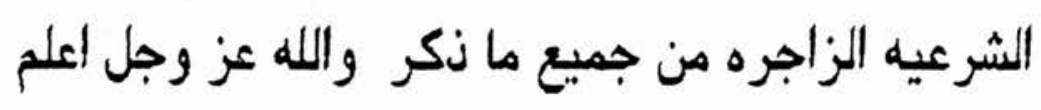

\section{هـ (0)}

عن امراة قيمة على اولادها القاصرين من قبل من له ذاللك شرعا

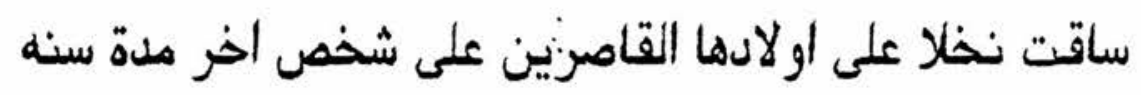

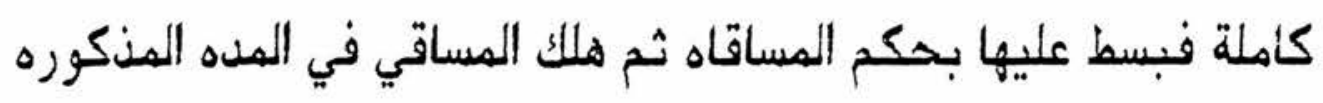

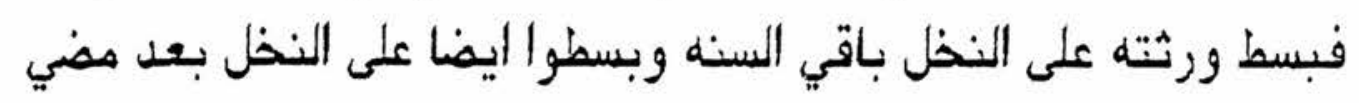

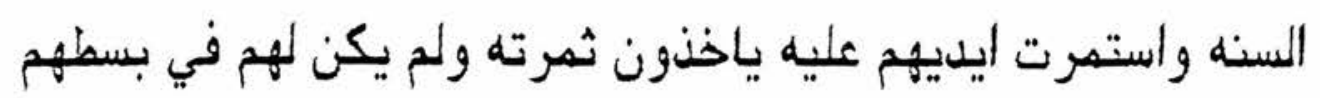

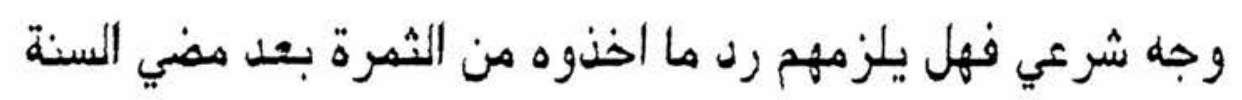

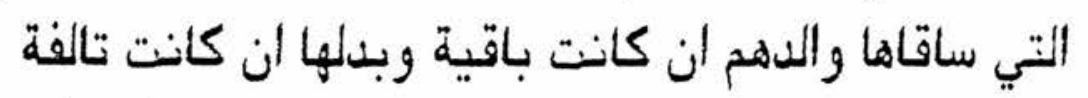

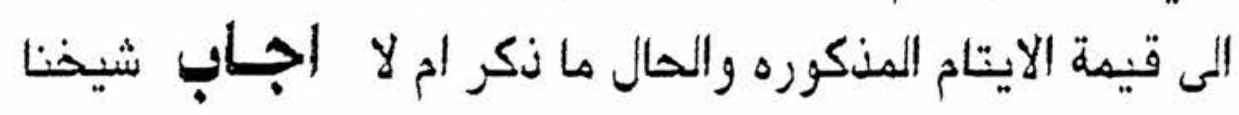

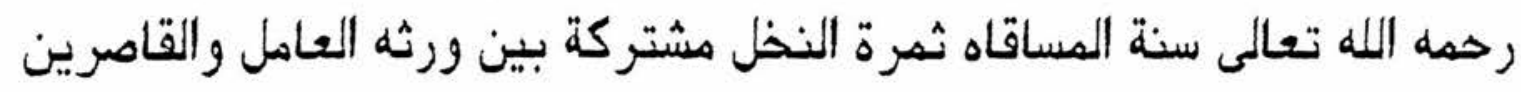

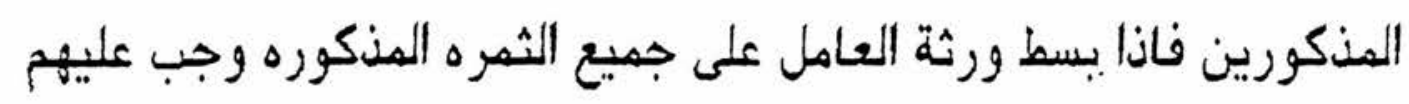

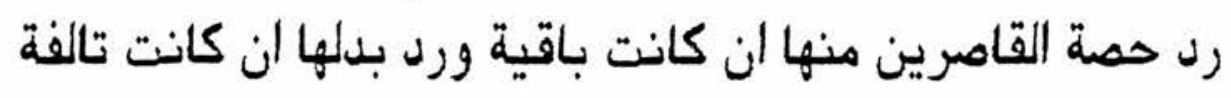

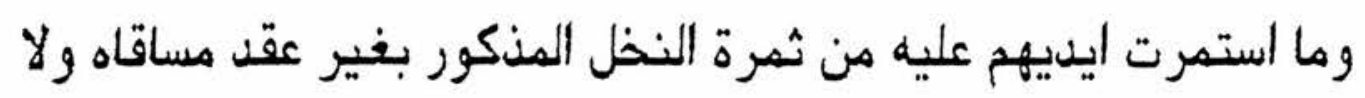
وجه شرعي وجب عليهم رده ان كان باقيا ومثله ان تلف الى القيهه المذكوره والله عز وجل أعلم علم رئ ان 
(T) هـســله عن رجل يملك نخلا ساقاه

على رجل اخر يسمى عاملا مده سنه كاملة على ان للعامل المساقي سهما واحدا وهو النصف من الثهره المتحصله من النخل في المده المذكوره

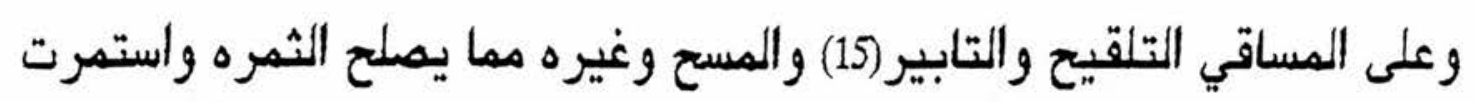
يده على النخل الى اوان حلول الثمره فوصل مالك النخل المى النخل فوجد ثمرته مختله وسد خلتها هن تقصير العامل عن عمل ما هو من شروط المل هل المساقاه

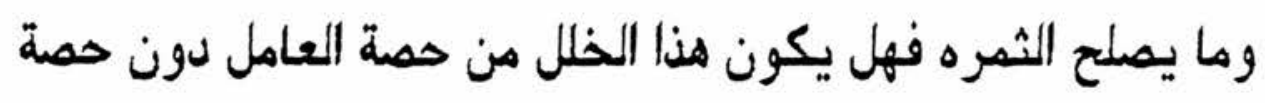

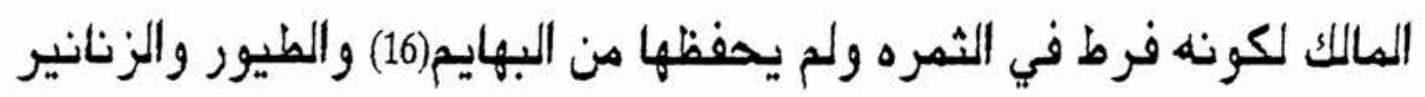

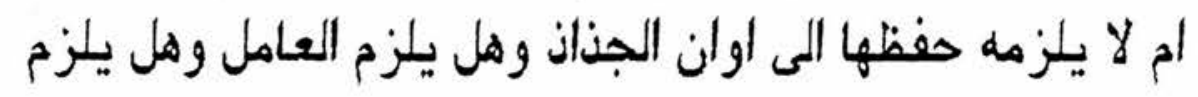

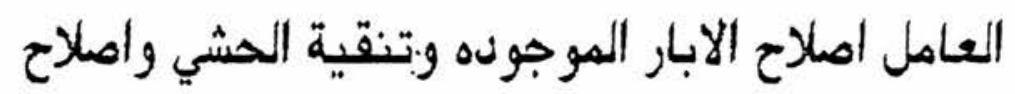

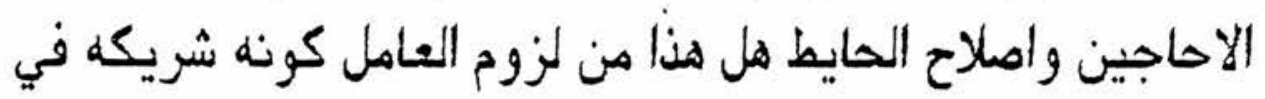

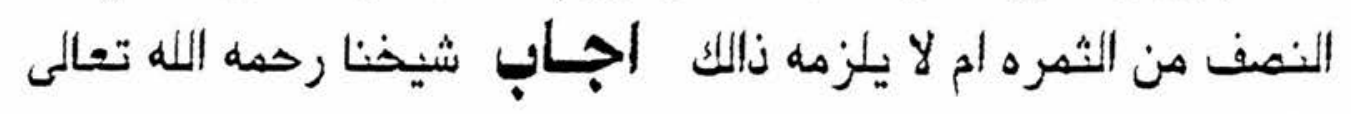

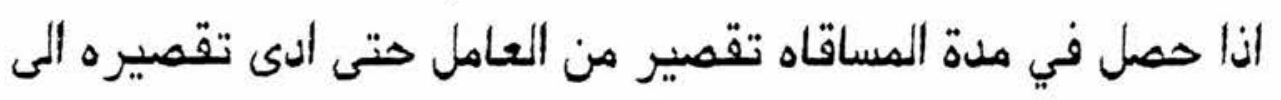

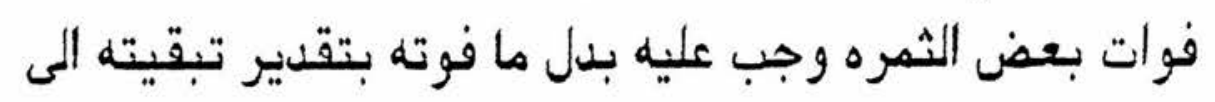

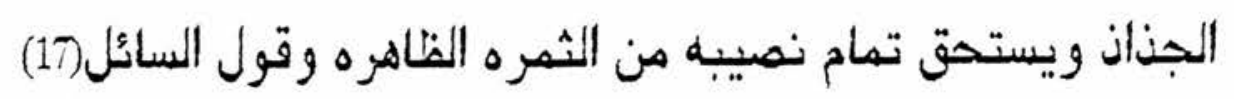

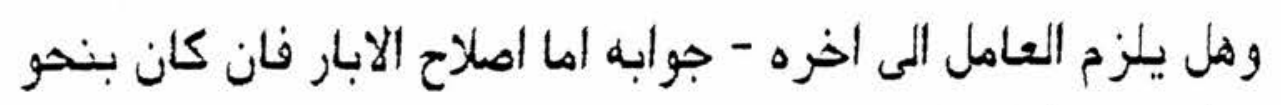

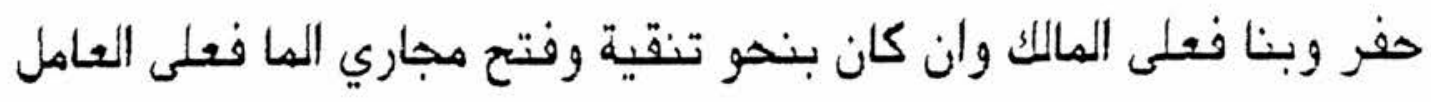

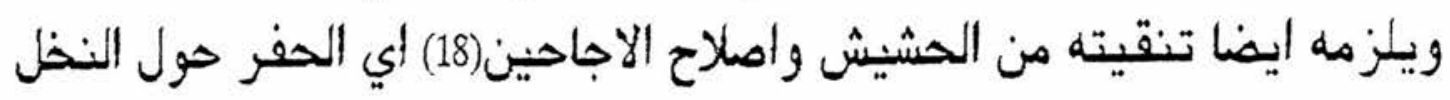

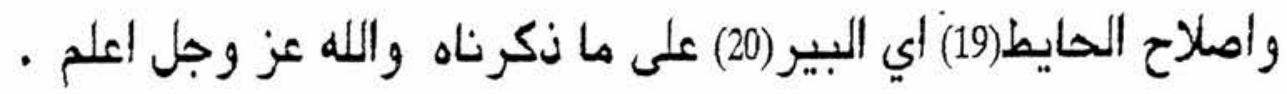




\section{Notes:}

(1) Here, and subsequently, the dots of tā marbütah are almost invariably omitted in the Ms. Hamzahs are also of ten omitted on the word mas'alah and on other words.

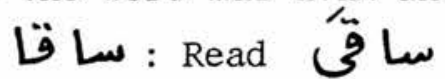

(3) Throughout the Ms., Sل्J is spelt with an alif.

(4) Throughout the Ms., dots are frequently omitted from the $\bar{j} \mathrm{~m}$ or the ba', or both, in the word ajaba.

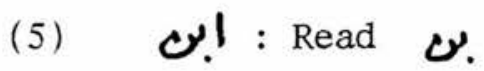

(6) Ibn Ziyād: As stated in Chapter 8 (Section 8.53 above), this is almost certainly the known Shāfic $\bar{i}$ authority ${ }^{c} A b d$ al-Rabmān bn cAbd al-Karìm bn Ziyād al-Muqriși al-Zabīdī, who died in 975/1567. He is mentioned again in Fatwa 3, below. .

(7) Abū Qushayr al-Haḑramī: Neither he nor his work a7-QaTa'id has so far been identified.

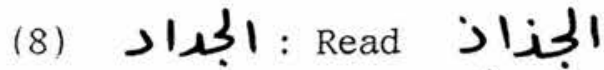

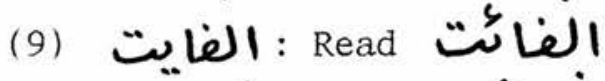

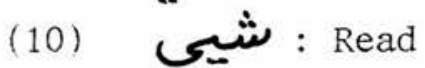

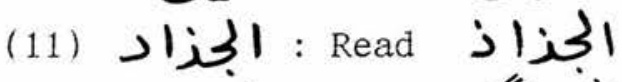

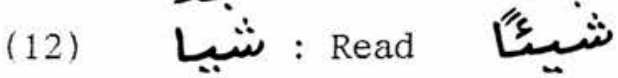

(13) ( see Lane 1863-93:636b).

(14) In the Ms., the hamzah is missing, only its chair being written.

(15) (W.) Read

(16) (17) 1: Read<smiles>CCC(C)(C)C(C)(C)C</smiles>

(17) In the Ms., the hamzah is missing, only its chair being written.

الأحامكي Read : الأما صيع(18)

(19) b. 31: Read 造 | I

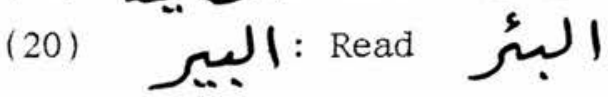


The Fatāwā of al-c Al lāmah Burhān a l-Dīn
Ibrāhīm bn Muhammad bn Ibrāhīm Ibn Jacmān

Bāb al-Musāqāh (p. 178b-180a)

[p.178b]

[1] Question concerning a person who has concluded a musāaāh contract with another man over specified date-palms for [a payment of] a specified part of the fruit, and then the said tenant was negligent in the work and in looking after the date-palms, and as a result of this there occurred a decrease in the fruit [yield]. Is [the tenant] responsible for this shortfall?

Our Shaykh al-cAllāmah Burhān al-Dīn Ibrāhīm bn Muhammad bn Ibrāhīm $\mathrm{Ja}^{c}$ mān (may God have mercy on·him) responded [as follows]: If during the period of the musāqāh contract there occurs negligence on the part of the tenant so that it has led to a loss of part of the fruit, then [the tenant] must compensate for the loss he has caused assuming he had remained until it was time to harvest.

Our Shaykh al-Mashāyikh al-cAllāmah Ibn Ziyād (may God have mercy on him) has delivered a fatwa in favour of the same view.

According to the QaTa'id of Abū Qushayr al-Hadramī, the sale [value] of the part of the fruit which has been lost is estimated together with the date-palm $\mathbf{1}$, assuming [the tenant] had remained until the harvest; then [the date-palm] stands on its own and anything in excess of this concerns the fruit ${ }^{2}$. All this applies if the loss occurs before the ripening [of the fruit]. Concerning [the situation when the loss occurs] after the ripening, the fruit is already guaranteed in the way it looks [and so its quantity and value will be already known without any estimation being necessary].

This completes this theme. [The view put forward here] is closest to the fatwäs about it given by al-cAllāmah

1 Presumably this means that the estimated monetary loss incurred from the lost fruit is added to the estimated value of any damage done to each date-palm because of the tenant's inattention.

2 Perhaps this means: The loss incurred by damage to the date-palms is then calculated separately and any loss remaining after this has been subtracted from the total loss is the part of the loss ascribable to the lost fruit. 
Ibn Ziyād and what has been mentioned concerning liability. The aim [of the rulings] concerns only the landowner's share of the fruit ${ }^{3}$, as is evident. God Almighty knows best.

[2] Question concerning a man who accused another man that he had entered into a musāqāh contract unquestionably with him in some date-palms in return for the value of part of the fruit but [that the other party] had not handed it over. The accused contested the case, and the plaintiff called a witness who testified that the plaintiff had a musāqāh contract with the accused in some date-palms, but he had not confirmed it during the year before the year of which the said plaintiff was complaining. Is this lawsuit, and the testimony and the musāqāh contract, valid or not?

Our Shaykh [Ibn $\mathrm{Ja}^{c}$ mān] (may God have mercy on him) responded: The musāqāh is not valid on the basis of the above-mentioned description, nor is the lawsuit [of the plaintiff], nor the testimony deriving from it,

[p.179a] and the accused is not bound [to hand over] any fruit, if the contract is on the basis of the description as explained [above]. God Almighty knows best.

[3] Question concerning a man who has concluded a musāqāh contract with another man in specified date-palms on the basis that the tenant would have a one-eighth share of the total of the fruit of the date-palms of the musāqāh contract, and the tenant was negligent in his obligations so that much of the fruit was lost. What is the tenant required to do?

Our Shaykh (may God have mercy on him) responded: The circumstances being as quoted, the liability is on the tenant to ensure [the pollination of] the spadices of the date-palms, which he had been deficient in looking after and tending, assuming that he remained until the harvest, and also those things which have already been mentioned concerning liability. The desired intention [of this ruling] is [to guarantee] only the share of the fruit for the [one who has] proprietorship, since the tenant cannot indemnify himself, and [in any case] the tenant has a right to his share of the fruit which has appeared.

This is like the fatwā given by our Shaykh al-Mashāyikh al-cAllāmah al-Muhaqqiq cAbd al-Rahmān Ibn Ziyād (may God have mercy on him), and we make use of his knowledge. Amen. God Almighty knows best.

3 Presumably this means: The ruling is intended to make sure the landowner gets his proper share, since the tenant himself has been responsible for any shortfall in his own share. 
[4] Question concerning a man who has a musāqāh contract with another man for a half-share of the fruit from a stipulated [plot of] date-palms and then the musāa $\overline{7}$-tenant damaged the date-palms and neglected them and did not carry out his duty in irrigating and shouting [to scare away animals and birds], and he took some of [the landowner's] property. So the owner of the date-palms forbade [the tenant] from doing this and [the tenant] abused [the landowner] and besmirched his honour. What must the above-mentioned [tenant] do concerning the spoiling of the date-palms and his abuse of the said [landowner]? Give us your fatwa.

Our Shaykh (may God have mercy on him) responded: The said [tenant] must make compensation for the said date-palm fronds he has taken and be fined for the damage to the date-palms if he has caused a loss to them. This [loss will be calculated as lying] between the value [of the palms] before anything was taken away and their value afterwards [?]. He must also pay an indemnity for the said spadices the loss of which he has caused [as reckoned] by assuming they had remained [?]. Concerning his abusing the owner of the date-palms, [the offender] must be reprimanded with one of the sharc $\overline{7}$ restraining reprimands which al-bākim al-sharc 7 (a legal arbitrator) considers as a suitable reprimand to him, [selecting it] from all those that have been mentioned. God Almighty knows best.

[5] Question concerning a woman who is the guardian of her under-age children as one who is empowered legally to [be] that, and who concluded a musāaāh contract over some date-palms on behalf of her under-age children with another person for a period of a complete year. [This person] took [the date-palms] over according to the musāqāh regulations. Then the musāa $\overline{7}$-tenant died within the said period and his heirs took over the date-palms for the remainder of the

[p.179b]year. They also remained in possession of the date-palms after the end of the year and they continued in control of [the date-palms] while taking the fruit from [the date-palms], even though they had no legal justification for their holding onto it. So: Is it obligatory for them to return the fruit they have taken after the end of the year for which their father had made the musäqäh contract, if [, that is,] [the fruit] is still in existence, or else its equivalent if it has been consumed, to the said woman guardian of the orphans, the situation being as quoted? Or is it not [obligatory for the heirs to do so]?

Our Shaykh (may God have mercy on him) responded: During the year of the musāqäh contract, the fruit of the date-palms is shared between the heirs of the tenant and the said minors. If the heirs of the tenant have taken over all 
the said fruit, they must return the minors' share of it if it still exists, or else return its equivalent if it is destroyed. [Concerning] the part of the fruit of the said date-palms which they have continued to hold onto after the end of the musāqāh contract, there is no legal

justification [for them to hold onto it]. They must return it if it still remains, or its equivalent if it has been consumed, to the said woman guardian. God Almighty knows best.

[6] Question concerning a man who owns some date-palms which he lets out on a musāqāh contract to another man who is named as tenant for a period of a complete year on the understanding that the musäq $\overline{7}$-tenant has one share, which is half of the fruit harvested from the date-palms during the said period, and it is the responsibility of the

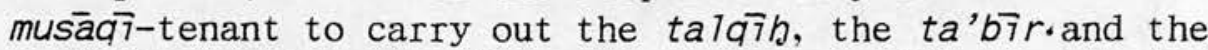
mash (i.e., the operations necessary to pollinate the date spadices) and to do the other things which make the fruit ripen properly. He remained in charge of the date-palms until the time of the arrival of the fruit. Then the owner of the date-palms came to the date-palms and found his 4 fruit deficient and he accounted for the deficiency by the fact that the tenant had been negligent in the work which was part of the conditions of the musāaāh contract and which make the fruit ripen properly. Is this deficiency [to be made up] from the share of the tenant, rather than from the share of the owner, since [the tenant] has been remiss with regard to the fruit and did not protect it from livestock, birds and flies? Or is it not his duty to protect [the fruit] until the time of the harvest? Is it the tenant's duty? Is it the tenant's dutys to keep in good repair the wells that are present, to clear out the grass, to keep in good repair the ahāj̄inn (the irrigation hollows around the base of the palms) 6 , and to keep the wall in good repair? Are these things among the duties of the tenant, he being

4 Or "their fruit", i.e., the fruit of the nakhl?

5 Probably an inadvertent repetition by the scribe of wa-hal yalzam al-eāmil.

6 abāj 7 : The term has been discussed in Chapter 8 (Section 8.2, and elsewhere). Although it is not listed in any of the usual lexical works, from what follows later in the text, where Ibn Jacman's gloss is a 7-bafr haw 7 al-nakhl, the meaning is clear: the abajjin are the banked hollows around the bases of the palm trunks to retain the irrigation water. 
the [owner's] sharik (partner) in half the fruit? Or are such not his duties?

Our Shaykh (may God have mercy on him) responded: If the tenant's negligence has occurred during the period of the musāqāh contract so that his negligence led to a loss of [p.180a] some of the fruit, he is required to replace what he has caused to be lost [evaluated by] assuming it had been left until the harvest. [The tenant] has a right to his full share of the fruit which has appeared. Concerning the question: Is the tenant responsible for [al1] the other things?, [Ibn Jacmän's] answer is: As for keeping the wells in good order, if [this] involves work such as digging and building, then the responsibility is on the owner; but if it involves work such as clearing and opening the water channels, then it is the reponsibility of the tenant. It is [the tenant's] duty also to keep things clear of grass and to keep in good repair the ahäj $\overline{7} n$, that is to say, the hollow dug round the date-palm, and to keep in good order the wall, that is to say, [the wall of] the well, on the basis of what we have already mentioned. God Almighty knows best. 


\section{BIBLIOGRAPHY}

- $303-$ 


\section{BIBLIOGRAPHY}

\section{Abbreviations:}

BSOAS: Bulletin of the School of Asian and African Studies.

EI ${ }^{1}$ : Encyclopaedia of Islam, Leiden, First Edition.

EI : $\quad$ Encyclopaedia of Islam, Leiden, Second Edition.

JESHO: Journal of the Economic and Social History of the Orient.

JNES: $\quad$ Journal of Near Eastern Studies.

RA: Revue algérienne (original full title: Revue algérienne, tunisienne et marocaine de législation et de jurisprudence), Algiers.

RSO: $\quad$ Rivista degli Studi Orientali.

\section{Primary Sources:}

\section{A. Manuscripts}

Bā Kathīr Ms.:

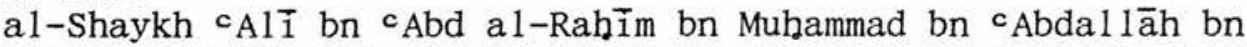

cumar, Qādì Bā Kathīr, Kitāb Tas'hīil al-Mudhākarah bi-Abkām

a1-Mukhābarah wa-a 1-Muzāracah wa-a 7-Mughärasah

wa-a 1-Munäsharah ..., Hadramī Ms., n.d. Copy in the R.B. Serjeant Collection, University of Edinburgh.

Ibn Jacmān Fatāwā Ms. :

Burhān al-Dīn Ibrāhīm bn Mubammad bn Ibrāhīm Ibn Jacmān (d. 1016/1607, Fatāwă, Yemeni Ms. (origin probably Zabỉd), n.d. Bound copy in the R.B. Serjeant Collection, University of Edinburgh.

Ibn Ziyād Muz̄̄̄ 7 al-cAnā' Ms. :

cAbd al-Rabmān bn cAbd al-Karīm bn Ziyād al-Maqsarī al-Zabīdī

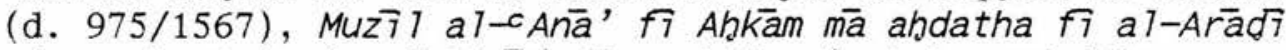
a)-muzdaracah min al-cAnā', Yemeni Ms. (origin probably Zabid), n.d.

Bound copy ( $13 \mathrm{pp}$.$) held by the Seminar für orientkunde,$ Mainz University. (The copy is apparently a slightly different version from the two copies of the same work in Sanc $\overline{\mathrm{a}}$, as listed in Isam Mohammed Al-Shanti The Arabic Manuscripts microfilmed by the Institute of Arab Manuscripts from the Manuscripts House in Sana' [sic], 1985, Catalogue Nos. 249 and 250.)

\section{B. Published Primary Sources:}

Abū Yūsuf Kitāb a 7-Kharāj (trans. Ali):

Abū Yūsuf (al-Kūfî) (d. ca.182/798), Kitāb a 1-Kharāj, translated by Abid Ahmad Ali (and revised by Abdul Hameed Siddiqui) as Kitab-u7-Kharaj (Islamic Revenue Code), Lahore, 1979. 
Abū Yūsuf Kitāb al-Kharāj (trans. Ben Shemesh):

Abū Yūsuf (al-Kūfî) (d. ca.182/798), Kitāb al-Kharāj, edited and translated with Introduction by A. Ben Shemesh as Vol.III of Taxation in Islam, Leiden, 1969.

al-Bukhārī Saḩ̄h:

Mubammad bn Ismāc $\bar{i} l$ al-Bukhār $\bar{i}$ (d.256/870), The Translation of the Meanings of Sabīh a 7-Bukhärī, translated and edited by Mubammad Mubsin Khān, Hilâl Yayınları, Ankara (6 vols.), 1976.

al-Fīrūzābādī al-Qämūs al-Muh̄̄ t:

al-Fīrūzābādī, Abū Tāhir Muhammad bn Yacqūb bn Muhammad bn Ibrāhīm Majd al-Dīn (d.819/1415), a7-Qämüs a 7-Mub̄̄t, re-edited by al-Tāhir Abmad al-Zāwī as Tartīb al-Qamūs al-Mub̄̄t (4 vols.), 2nd edition 1390/1970, Dār al-Fikr, [Beirut].

al-Hamdānī a 7-IK T77 7:

Abū Muhammad al-Hasan bn Abmad bn Yacqūb al-Hamdānī (d. ca. $336 / 947)$, Kitāb a $7-I k T 77$, Vol. VIII, edited by Muhammad bn cAlī al-Akwac al-Hiwālī, Beirūt, 1407/1986.

al-Hamdānī Jaz̄̄rat al-cArab:

Abū Muhammad al-Hasan bn Ahmad bn Yacqūb al-Hamdānī (d. ca. 336/947), Sifat Jazīrat a 7-cArab, edited by Muhammad bn cA1i al-Akwac al-Hiwālī, Riyād, 1394/1974.

Ibn Manzūr Lisān al-cArab:

Muhammad bn Mukarram Ibn Manzūr (d.711/1311), Lisān a 1-cArab

(6 vols.), Dār al-Māārif, Cairo, [n.d.].

Ibn al-Murtadāa a 7-Bahr a 7-Zakhkhār:

Ahmad bn Yahyā Ibn al-Murtad̄ā (d.840/1437), a 7-Babr

a1-Zakhkhār a1-Jamic 7i-Madhähib culamā' al-Amsār, edited by ${ }^{c} A l i \overline{~ b n}{ }^{c} A b d$ al-Karīm bn Muhammad al-Fadīl Sharaf al-Dīn, (6 vols.), Beirut, 1394/1975 : I, 15.

Khān (trans l. and ed.) 1976:

Muhammad Mubsin Khan (transl. and ed.), The Translation of the Meanings of Sah̆̄in al-Bukhärī. Hilâl Yayınları, Ankara, 1976.

Mus lim Saḩ̄h:

Muslim bn al-Hajjāj (d.261/875), Saḩ̄̄b Muslim bi-Sharh a7-Nawawi, al-Maţbacah al-Misrîyah bi-al-Azhar, Cairo (10 vols.), 1929.

al-Nawawī Minhäj al-Tălibīn:

Muhyā al-Dīn Yahyā bn Sharaf al-Nawawī (d.676/1277), Minhāj al-Tâlibīn, published as: Minhâdj at-Tâlibîn: le guide des zélés croyants. Manuel de Jurisprudence musulmane selon le rite de Chafi' $\hat{\imath}$ (Arabic text with French translation), edited and translated by L.W.C. Van Den Berg (3 vols.), Batavia, 1883 . 
a7-Qänūn a7-Madan̄i:

a 7-Qanün a 7-Madan̄ (The Civil Code of the Yemen Arab

Republic) (4 vols.), Sancā', 1399-1403/1979-1983.

Qudāmah Kitāb a7-Kharāj:

Abū al-Faraj Qudāmah bn Jacfar al-Kātib al-Baghdādī

(d.320/932), Kitāb a7-Kharāj, Part VII, edited and translated with Introduction by A. Ben Shemesh as Vol.II of Taxation in Islam, Leiden, 1965.

al-Shāficī, Kitāb a 7-Umm:

al-Imām Muhammad bn Idrīs al-Shāficī (d. 204/820), Kitāb

al-Umm, Būlāq (7 vols.), 1321-26[/1901-06].

al-Shāficī, al-Risālah:

al-Imām Muhammad bn Idrīs al-Shāficī (d. 204/820), Kitāb al-Risālah fi Usül al-Fiah: Treatise on the Foundations of Islamic Jurisprudence, translated, with Introduction, by Majid Khadduri, Johns Hopkins Press, 1961 (repr. Is l'amic Texts Society, Cambridge, 1987).

al-Shāficī, Tartīb a 7-Musnad:

al-Imām Muhammad bn Idris al-Shāfici (d. 204/820), Tart $\bar{i} b$ a 7-Musnad, Cairo, 1380/1951.

al-Shawkānī Nayl al-Awtār:

Muhammad bn ${ }^{\mathrm{c} A 1} \overline{\mathrm{i}}$ bn Muhammad al-Shawkānī (d.1255/1830), Nay 7

al-Awtār min Ahādīth Sayyid al-Akhtār (6 vols.), Beirut, [1973].

Siddiqi (trans1. and ed.) 1976:

cAbdul Hamid Siddiqi, (transl. and ed.), Sah̄ih Muslim

(4 vols.), Lahore, 1976.

Taj a7-cArüs:

Taj $j$ al-cArūs of Muhammad Murtad̄a al-Husaynì al-Zabīdī, Kuwaiti edition, 1385/1965- .

Yahyā bn Adam Kitāb a 7-Kharāj:

Yahyā b. Adam (d. 818), Kitāb al-Kharāj, edited and translated with Introduction by A. Ben Shemesh as Vol.I of Taxation in Islam, Leiden, 1958.

Yāqūt, Muc jam al-Udabā':

Shihāb al-Dīn Abū cAbdallāh Yāqūt al-Hamawī al-Rūmī, Kitāb

Irshäd a 1-Ar̄̄b i Ta Macrifat a 7-Adīb, a 7-macrüf bi-Muc jam

al-Udabā', edited by D.S. Margoliouth (7 vols.), London, 1923-30.

Yemen Republic 1991:

Al-Jumhūrīyah al-Yamaniyah, wizārat al-takhțit

wa-al-tanmiyah, al-Jihāz al-markazì li-al-ibsā' : Kitāb

al-ibsă' al-sanaw̄ 7i-cām 1990 m., Sancà', September 1991. 
Yemen Republic 1992:

Al-Jumhūrīyah al-Yamanīyah, Wizārat al-Zirācah wa-al-Mawārid al-Mā'īyah, al-Idārah al-cAmmah li-al-Ibsā' al-Zirācī

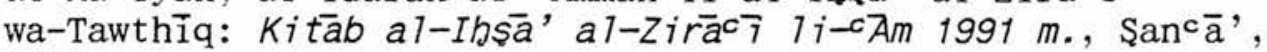
1992.

\section{Secondary Sources:}

Abd al-Kader 1959:

Ali Abd al-Kader, "Land property and land tenure in Islam", The Islamic Quarter7y, 5 (1959) :4-11.

Abribat 1934:

J. Abribat, "Du habous, du bail à complant et du bail à défrichement", RA, 50 (1934) Pt.1 (Doctrines et Législation) :103-118 and 119-128.

Abū Ghānim 1990:

Fad̆l cAlī Ahmad Abū Ghānim, a7-Qab̄̄ lah wa-a7-Dawlah fi

al-Yaman, Dār al-Minār, Cairo, 1410/1990.

cAfif et al. (eds.) 1992:

Abmad Jābir cAfīf et a7. (eds.), a 7-Mawsūcah al-Yaman̄iyah, Dār al-Fikr al-Mucāsir, Beirut, 1412/1992.

Agee (with Evans) 1965:

James Agee (with Walker Evans), Let Us Now Praise Famous Men, Owen, London, 1965.

Aghnides [n.d.]:

Nicolas P. Aghnides, Mohammedan Theories of Finance, Lahore, [n.d.].

al-Ahdal 1990:

Hasan Muhammad Maqbūlī al-Ahdal, "A7-Imām a 7-Shawkān $\overline{7}$ Muhaddithan wa-Athru-hu fi cI7m a7-Hadith", Diräsät Yaman̄yah, Yemen Centre for Studies and Research, 40 (1410/1990) :260-283.

Almenouar 1939:

Kellal Almenouar, "Sidi Khalil et le contrat de Mogharassa [sic]", RA, 55 (1939) Pt.1 (Doctrines et Législation) :25-32.

al-cAmri 1985:

Husayn cAbdallāh al-cAmrī, The Yemen in the 18th and 19th centuries: a Political and Intellectual History, London, 1985 .

al-cAmrï 1992a:

Husayn cAbdallāh a1-cAmrī, article "Abmad bn Yahyā al-Murtad̄a", in cAfïf et a7. (eds.) 1992 (a7-Mawsickah a1-Yamanīyah) (q.v.) :I, 66a-67a. 
al-cAmri 1992b:

Husayn cAbdallāh al-cAmrī, article "Yahyā bn al-Husayn bn al-Qāsim", in cAfïf et al. (eds.) 1992 (a7-Mawsücah a)-Yamanīyah) (q.v.) :II, $1018 \mathrm{~b}$.

al-cAmri 1992c:

Husayn cAbdallāh al-cAmrī, article "Yahyā bn Hamzah bn "Alī", in cAfïf et al. (eds.) 1992 (a 7-Mawsücah al-Yamanīyah) (q.v.) : I I, 1019a-b.

al-cAmri 1992d:

Husayn cAbdallāh al-cAmrī, article "Muhammad bn ${ }^{c} A l \bar{i}$ al-Shawkānī", in "Afîf et al. (eds.) 1992 (al-Mawsícah al-Yamanīyah) (q.v.) :II, 828b-829b.

al-cAmri 1992e:

Husayn cAbdallāh al-cAmrī, article "cAbd al-Razzāq bn Hammām al-Sancāni", in cAfif et a7. (eds.) 1992 (a 7-Mawsúcah a7-Yamanīyah) (q.v.) :II, 633a.

Anderson 1976:

N. Anderson, Law Reform in the Muslim World, London, 1976.

Aston and Philpin (eds.) 1985:

T.H. Aston and C.H.E. Philpin (eds.), The Brenner Debate: Agrarian Class Structure and Economic Development in Pre-Industrial Europe, Cambridge, 1985.

al-Azmeh 1988:

Aziz al-Azmeh, "Islamic Legal Theory and the Appropriation of Reality", in al-Azmeh (ed.) 1988 (q.v.) :250-265.

al-Azmeh (ed.) 1988:

Aziz al-Azmeh (ed.), Islamic Law: Social and Historical Contexts, London, 1988.

Bā Dhīb 1991:

cAlī Sālim Bā Dhīb, Al-Nabātāt al-tibbīyah fī al-Yaman, $\operatorname{San}^{c} \bar{a}$ ', 1411/1991.

Baker and Edge 1990:

P.W. Baker and I.D. Edge, "Islamic legal literature", in:

Young, Latham and Serjeant (eds.) 1990 (q.v.) :139-154.

Balhājj 1990:

Mubammad Muştafā Balhājj, "A7-Taharrur a1-fikri

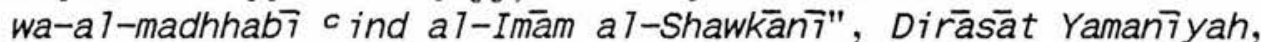
Yemen Centre for Studies and Research, 40 (1410/1990) :247-259.

Ballantyne 1990:

W. Ballantyne, "A reassertion of the Shar $\bar{i}^{c}$ ah: the jurisprudence of the Gulf States", Islamic Law and Jurisprudence, edited by N. Heer, Seattle and London, 1990, :149-159. 
Ben Shemesh 1958-69:

A. Ben Shemesh, Taxation in Islam (3 vols.), Leiden: Vol.I 1958; Vol.II 1965; Vol.III 1969.

Bosworth 1967:

C.E. Bosworth, The Islamic Dynasties, Edinburgh, 1967.

Bosworth $E I^{2}$ :

C.E. Bosworth, EI², article "Mukāsama".

Bosworth et al. EI :

C.E. Bosworth, E. van Donze1, W.P. Heinrichs and Ch. Pellat $E I^{2}$, article "Mughārasa".

Brockelmann 1937-49:

Carl Brockelmann, Geschichte der Arabischen Literatur

(2 vols., and 3 vols. in Supplement), Leiden, 1937-49.

Bruno 1913:

Henri Bruno, Le Régime des Eaux en Droit musulman, Doctoral

Thesis published by A. Rousseau, Paris, 1913.

Byres 1983:

T.J. Byres, "Historical Perspectives on Sharecropping", in Byres (ed.) 1983 (q.v.) :7-40; reprinted as T.J. Byres, "On share-croppers and share-cropping", Journal of Peasant Studies, 10 (1983) :7-40.

Byres (ed.) 1983:

T.J. Byres, Sharecropping and Sharecroppers, Frank Cass, London, 1983.

Chaumont $E I^{1} \mathrm{a}$ :

E. Chaumont, $E I^{1}$, article "Al-Shäficīi".

Chaumont $E I^{1} \mathrm{~b}$ :

E. Chaumont, EI ${ }^{1}$, article "Al-Shāficiyya".

Chehata 1968:

Chafik Chehata, "Le contrat en droit musulman", Zeitschrift für vergleichende Rechtswissenschaft, 70 (1968) :81-96.

Chehata $E I^{2}$ :

Chafik Chehata $E I^{2}$, article "cAkd".

Chelhod 1972:

J. Chelhod, "La Société yéménite et le kat", Objets et Mondes, 12 (1972) :3-22.

Chelhod 1975:

J. Chelhod, "La Société yéménite et le droit", L'Homme, 15 (1975) :67-86. 
Chelhod 1986:

J. Chelhod, "La place de la coutume dans le figh primitif et sa permanence dans les societés arabes à tradition orale", Studia Islamica, 64 (1986) : 19-37.

Cooper 1983:

Adrienne Cooper, "Sharecroppers and landlords in Bengal, 1930-50: the dependency web and its implications", in Byres (ed.) 1983 (q.v.) :227-255.

Cooper 1988:

Adrienne Cooper, Sharecropping and Sharecroppers' Struggles in Benga 7, 1930-50, Calcutta and New Delhi, 1988.

Cooper 1985:

J.P. Cooper, "In search of agrarian capitalism", in Aston and Philpin (eds.) 1985 (q.v.) :138-191.

Conrad 1965:

David E. Conrad, The Forgotten Farmers: the Story of

Sharecroppers in the New Deal, University of Illinois Press, Urbana, 1965.

Coulson 1964:

N.J. Coulson, A History of Islamic Law, Edinburgh University Press, 1964.

Dennett 1950:

D.C. Dennett, Conversion and the Poll Tax in Early Islam, Harvard University Press, Cambridge, Mass., 1950.

Doi 1984:

cAbdur Rahmān I. Doi, Shar̄icah: The Islamic Law, London, 1984 .

Donaldson 1994:

W.J. Donaldson, "Units of Counting and Aggregation in Omani Arabic", Journal of Semitic Studies, 39 (1994) :87-96.

Donaldson 1996:

W.J. Donaldson, "Observations on Measures of Capacity in Present-day Northern Yemen", New Arabian Studies 3, edited by G. Rex Smith, J.R. Smart and B.R. Pridham, $1996: 33-49$.

Dostal 1992:

Walther Dostal, "al-cUrf", in "Afif et al. (eds.), a7-Mawsīc ah a 7-Yaman̄iyah (q.v.) :645b-654a.

Dozy 1881:

R. Dozy, supplément aux dictionnaires arabes (2 vols.), Leyden, 1881.

Dresch 1993:

Paul Dresch, Tribes, Government and History in Yemen, Oxford, 1989; republished Oxford 1993. 
Duby 1968:

Georges Duby, Rural Economy and Country Life in the Mediaeval West, trans1. Cynthia Postan, London, 1968.

Dürī 1974:

cAbdal cAzizz Dūrī, "Note on taxation in early Islam", JESHO, 17 (1974) :136-144.

Eagle 1994:

A.B.D.R. Eagle, "Al-Hādī Yahyā b. a1-Husayn b. al-Qāsim (245-98/859-911): a biographical introduction and the background and significance of his imamate", New Arabian Studies 2, edited by R.L. Bidwell, G. Rex Smith and J.R. Smart, 1994 :103-122.

English 1968:

Paul W. English, "The origin and spread of qanats in the old World", Proceedings of the American Philosophical Society, 112 (1968) : 170-181.

Escher 1976:

Hermann A. Escher, Wirschafts- und sozialgeographische Untersuchungen in der Wâdî Mawr Region (Arabische Republik Jemen), Beihefte zum Tübinger Atlas.des Vorderen Orients Nr. 23, Wiesbaden, 1976.

FAO 1973:

FAO, Water Laws in Moslem Countries, Irrigation and Drainage Paper No. 20/1, Rome, 1973.

Fisher 1919:

Stanley Fisher (transl. and annot.), Ottoman Land Laws, containing the Ottoman Land Code and Later Legislation Affecting Land, Oxford U.P., 1919.

Fyzee 1955:

Asaf A.A. Fyzee, Outlines of Muhammadan Law, 2nd edition, Oxford 1955 .

Gi11 1983:

Desmond Gil1, "Tuscan sharecropping in United Italy: the myth of class collaboration destroyed", in Byres (ed.) 1983 (q.v.) :146-169.

Goldziher 1910:

Ignaz Goldziher, Vorlesungen über den Islam, Heidelberg, 1910; translated from the German as Introduction to Islamic Theology and Law by Andras and Ruth Hamori, Princeton, 1981.

Hal im 1983:

Fatimah Halim, "The major mode of surplus labour appropriation in the West Malaysian countryside: the sharecropping system", in Byres (ed.) 1983 (q.v.) :256-278. 
Haque 1977:

Ziaul Haque, Landlord and Peasant in Early Islam: a Study of the Legal Doctrine of Muzāraca or Sharecropping, Islamic Research Institute, Islamabad, 1977.

Hart 1961:

H.L.A. Hart, The Concept of Law, Oxford, 1961.

Hava 1899:

J.G. Hava, 1899, al-Farā'id a7-Durrīyah: Arabic-English

Dictionary, Beirut (repr. 1982).

Heffening $E I^{2}$ :

W. Heffening, $E I^{2}$, article "Al-Nawawī".

Hinz 1955:

Walther Hinz, Islamische Masse und Gewichte umgerechnet ins Metrische System, Handbuch der Orientalistik, Ergänzungsband 1, Heft 1, Leiden, 1955.

Hooper 1933:

C.A. Hooper, The Civit Law of Palestine and Trans-Jordan,

(2 vols.), Jerusalem, 1933; reprinted London, 1938.

Imber 1997:

Colin Imber, Ebu 's-Sucud: The Islamic Lega7 Tradition, Edinburgh, 1997.

Jabalī 1993:

Sacīd cAbduh Jabalīi, Al-Nabātāt al-shajar̄̄yah fị a7-Yaman, cAden, 1993.

al-Jazīri 1969:

cAbd al-Rahmān al-Jazīrī, Kitāb al-Fiqh caTa al-Madhāhib al-Arbacah, al-Maktabah al-Tijārīyah al-Kubrā (4 vols.), Cairo, 1969.

Kamali 1991:

M.H. Kamali, Principles of Islamic Jurisprudence, (revised edition ), Cambridge, 1991.

Keegan 1983:

Timothy Keegan, "The Sharecropping Economy on the South African Highveld in the Early Twentieth Century", in Byres (ed.), 1983 (q.v) :201-226.

Kennedy 1987:

John G. Kennedy, The Flower of Paradise: the

Institutionalized Use of the Drug Qat in North Yemen, Dordrecht, 1987.

Keyder 1983:

Cağlar Keyder, "The Cycle of Sharecropping and the Consolidation of Small Peasant Ownership in Turkey", in Byres (ed.), 1983 (q.v) :130-145. 
Khadduri 1961:

Majid Khadduri, al-Shäficī's al-Risālah (Introduction and Translation), Johns Hopkins Press, 1961 (repr. Islamic Texts Society, Cambridge, 1987) (q.v.).

Köhler $E I^{2}$ :

M.A. Köhler, EI², article "Munāsafa".

Lambton 1969:

Ann K.S. Lambton, Landlord and Peasant in Persia, London, 1953; new edition 1969.

Lambton $E I^{2}$ :

Ann K.S. Lambton, EI ${ }^{2}$, article "Kanāt".

Landberg 1920-42:

Le Comte de Landberg, Glossaire Datînois (3 vols.), Leiden, 1920-42.

Lane 1863-93:

E.W. Lane, An Arabic-English Lexicon, London, 1863-93; repr. Islamic Texts Society, Cambridge (2 vols.), 1984.

Latham $E I^{2}$ :

J.D. Latham, EI², article "Mushāraka".

Lawless 1994:

R.I. Lawless, "Recruitment and regulation: migration for employment of 'Adenese' seamen in the late nineteenth and early twentieth centuries", New Arabian Studies 2, edited by R.L. Bidwe11, G. Rex Smith and J.R. Smart, 1994 :75-102.

Layish and Shmueli 1979:

A. Layish and A. Shmueli, "Custom and Shar $\bar{i}^{c}$ ah in the Bedouin family according to legal documents from the Judaean Desert", BSOAS, 72 (1979) :29-45.

Løkkegaard 1950:

Frede Løkkegaard, Islamic Taxation in the Classic Period, with special reference to circumstances in Iraq, Copenhagen, 1950; reprinted Philadelphia 1978.

Madelung $E I^{2}$ :

W. Madelung, EI², article "Imāma".

Makin (ed.) 1977:

M.J. Makin (ed.), Irrigation and Agricultural Development in Wadi Rimac, [part of] Yemen Arab Republic Montane Plains and Wadi Rimac Project: a Land and Water Resources Survey, Project Report 16, Ministry of Overseas Development, Land Resources Division, Surbiton, 1977. 
Maktari 1971a:

A.M.A. Maktari, Water Rights and Irrigation Practices in Labj: a Study of the Application of Customary and Sharicah Law in South-West Arabia, Oriental Publications No.21, University of Cambridge Press, 1971.

Maktari 1971b:

A.M.A. Maktari Land Tenure and Water Rights in Wad7 $\sqrt{7} z \bar{a} n$, Report for the Government of the Kingdom of Saudi Arabia, on behalf of Sir William Halcrow \& Partners, London (under assignment from the FAO), 1971.

Mandle 1983:

Jay R. Mandle, "Sharecropping and the Plantation Economy in the United States South", in Byres (ed.), 1983 (q.v) :120-29.

Mil1 1848:

John Stuart Mi11, Principles of Political Economy, London, 1848: repr. London, 1981.

Milliot 1911:

Louis Milliot, L'Association agricole chez les Musulmans du Maghreb (Maroc, Algérie, Tunisie), Doctoral Thesis published by A. Rousseau, Paris, 1911.

\section{Milliot 1953:}

Louis Milliot, Introduction à 7 'étude du Droit Musulan, Paris, 1953.

Mitche11 1978:

Brigitta Mitche11, Yemen Arab Repub7ic Feeder Road Study: Summary Report: Taiz-Turba and Wadi Mawr Baseline Socio-Economic Survey Findings, Regional Development Unit, Transportation Department, The World Bank, Washington, 1978.

Mitchel1 and Escher 1978:

Brigitta Mitchell and Hermann Escher, Yemen Arab Republic Feeder Road Study: a "During Construction" Survey of the Taiz-Turba Road Influence Area, Regional Development Unit, Transportation Department, The World Bank, Washington, 1978.

Mitchell et a7. 1978:

Brigitta Mitche11, Hermann Escher and Martha Mundy, $A$ Baseline Socio-Economic Survey of the Wadi Mawr Region: Yemen Arab Republic Feeder Road Study, Regional Development Unit, Transportation Department, The World Bank, Washington, 1978.

Mundy 1981:

Martha Williams Mundy, Land and Fami7y in a Yemeni Community, Unpublished Ph.D. Thesis, University of Cambridge, 1981.

Nadvi 1971:

Syed Habibul Haq Nadvi, "A1-'Iqțā" [sic] - or theory of land ownership in Islam", Islamic Studies, 10 (1971) :257-276. 
a1-Nawāwi 1973:

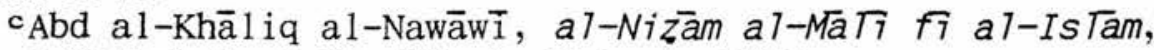
al-Maktabah al-cArabiyah, Beirut, 1973.

Noë1 1938:

Philippe Noël, "Le métayage indigène Nord-Tunisien", Institut des Belles Lettres arabes (IBLA), Year 2 (1938) :3-17.

$\mathrm{Nu}^{\mathrm{c}} \operatorname{mān}$ 1989:

cAbdallāh Abmad Nucmān, Qađāyā wa-Mushki Tat al-Tanmīyah a1-zirācīyah: a1-Hiyäzät al-zirācīyah fị al-Jumhürīyah a1-CArab̄̄yah a 1-Yaman̄̄yah, Dār al-Fārābī, Beirut, 1989.

Ongeley 1892:

F. Ongeley (transl.), The Ottoman Land Code, revised and edited Horace E. Miller, London, 1892.

Piamenta 1990-91:

Moshe Piamenta, Dictionary of Post-Classical Yemeni Arabic (2 vols.), Leiden, 1990-91.

Poliak 1936:

A.N. Poliak, "La féodalité islamique", Revue des Études islamiques, 10 (1936) :247-265.

Poliak 1940:

A.N. Poliak, "Classification of lands in the Islamic law and its technical terms", American Journal of the Semitic Languages and Literatures, 57 (1940) :50-62.

Pouyanne 1939:

Maurice Pouyanne, "Documents pour servir à l'histoire du contrat de khammessat en Algérie", RA, 55 (1939) Pt.1 (Doctrines et Législation) :97-139.

Pratt 1994:

J. Pratt, The Rationality of Rural Life: Economic and Cultural Change in Tuscany, Harwood Academic Publishers, Chur, Switzerland, 1994.

Rafīdah 1990:

Ibrāhīm cAbdallāh Rafīdah, "A7-Imām Muhammad bn ${ }^{c} A \sqrt{7}$ a1-Shawkān̄̄: al-CA7im, a1-Mujtahid, al-Mufassir", Dirāsāt Yamaniyah, Yemen Centre for Studies and Research, 40 (1410/1990):284-342.

Rathjens 1951:

Carl Rathjens, "Tâghût gegen scherî'a: Gewohnheitsrecht und islamisches Recht bei den Gabilen des jemenitischen Hochlandes", Jahrbuch des Linden-Museums, 1951 :172-187. 
Rayner 1991:

S.E. Rayner, The Theory of Contracts in Islamic Law: A Comparative Analysis with particular reference to the Modern Legislation in Kuwait, Bahrain and the United Arab Emirates, Graham and Trotman, London, 1991.

Rectenwald 1930:

Georges Rectenwald, "Le contrat de Mogharsa [sic] et la culture de l'olivier dans la région de Sfax", Bulletin du Comité de 7'Afrique française, Supplément: Reseignements coloniaux, No.2 for February 1930 :74-84.

Reid 1973:

Joseph D. Reid, "Sharecropping as an understandable market response - the post-bellum South", Journal of Economic History, 33 (1973) :106-130.

Rossi 1939:

E. Rossi, L'Arabo parlato a Sancá', Rome, 1939.

Rossi 1948:

E. Rossi, "Il diritto consuetudinario delle tribù arabe de 1 Yemen", RSO, 23 (1948) :1-36.

Rossi 1953:

E. Rossi, "Note sul1' irrigazione, l'agricoltura e le stagione nel Yemen", Oriente Moderno, 33, 8/9 (1953) :349-361.

Rostovtzeff 1922:

Michael Rostovtzeff, A Large Estate in Egypt in the Third Century B.C.: A Study in Economic History, Studies in the Social Sciences and History No.6, University of Wisconsin, Madison, 1922.

Roussier-Théaux 1935:

J. Roussier-Théaux, "Le contrat de mougharasa [sic]: à propos d'un livre récent", RA, 51 (1935) Pt.1 (Doctrines et

Législation) : 129-135.

Ste. Croix 1981:

G.E.M. de Ste. Croix, The Class Struggle in the Ancient Greek World, Duckworth, London, 1981.

Schacht 1950:

J. Schacht, The Origins of Muhammadan Jurisprudence, Oxford, 1950 .

Schacht 1964:

Joseph Schacht, An Introduction to Islamic Law, Oxford, 1964.

Schacht $E I^{2}$ :

J.Schacht, EI $I^{2}$, article "Bayc". 
Serjeant 1951:

R.B. Serjeant, "Two tribal law cases", Journal of the Roya 7 Asiatic Society, (1951):33-47 and 156-69.

Serjeant 1955a:

R.B. Serjeant, "Forms of Plea: a Sāficī manual from al-Sihr", RSO, 30 (1955) :1-15.

Serjeant 1955b:

R.B. Serjeant, R.B., "Two sixteenthhcentury Arabian geographical works", BSOAS, 17 (1955) :254-75.

Serjeant 1962a:

R.B. Serjeant, "Haram and bawtah, the sacred enclave in Arabia", Mélanges Tăhā Husain, Cairo, 1962 :41-58; reprinted in Serjeant 1981b (q.v.).

Serjeant 1962b:

R.B. Serjeant, "Recent marriage legislation from al-Mukalla with notes on marriage customs", BSOAS, 25 (1962) :472-498.

Serjeant 1964:

R.B. Serjeant, "Some irrigation systems in Hadramawt", BSOAS, 27 (1964) :33-76; reprinted in Serjeant 1995 (q.v.).

Serjeant 1979:

R.B. Serjeant, "Customary law documents as a source of history", Studies in the History of the Arabs, vol.1: Sources for the History of Arabia, Riyād, 1979 :99-103.

Serjeant 1980:

R.B. Serjeant, "Customary law among the fishermen of al-Shihr", Middle East Studies and Libraries: a Felicitation Volume for Professor T.D. Pearson, edited by B.C. Bloomfield, London, 1980 :193-203; reprinted in Serjeant 1995 (q.v.).

Serjeant 1981a:

R.B. Serjeant, "A maquāmah on palm-protection (shirähah)", JNES, 40 (1981) :307-322; reprinted in Serjeant 1995 (q.v.).

Serjeant 1981b:

R.B. Serjeant, Studies in Arabian History and Civilisation, Variorum Reprints, London, 1981.

Serjeant 1988:

R.B. Serjeant, "Observations on irrigation in South west Arabia", Proceedings of the Twenty-first Seminar for Arabian Studies held at Durham July 1987, :145-153; reprinted in Serjeant 1995 (q.v.).

Serjeant 1991:

R.B. Serjeant, Customary and Sharīcah Law in Arabian Society, Variorum Reprints, London, 1991. 
Serjeant 1992:

R.B. Serjeant, "The customary law of south-west Arabia and bedouin justice in Jordan", La Coutume/Custom: Recueils de la Société Jean Bodin, 53 (1992), Brussels :269-280.

Serjeant 1995:

R.B. Serjeant, Farmers and Fishermen in Arabia: Studies in Customary Law and Practice, edited by G. Rex Smith, Variorum Reprints, London, 1995.

Serjeant, Costa and Lewcock 1983:

R.B. Serjeant, P. Costa and R. Lewcock, "The Ghayls of Sancā,", in Serjeant and Lewcock (eds.) 1983 (q.v.) :19-31.

Serjeant and Lewcock (eds.) 1983:

R.B. Serjeant and R. Lewcock (eds.), Sancā': an Arabic Is Tamic City, London, 1983.

Shāhir 1991:

Khālid cAbd al-Jalīl Shāhir, "a7-Bunyah a 1-ijtimācīyah a 7-taq T̄ d7yah fi al-Yaman", Dirāsāt Yaman̄yyah, 43

(1411/1991), Sanc'a' :211-48.

a1-Shamāhī 1985:

cAbdallāh bn cAbd al-Wahhāb a1-Mujāhid al-Shamāhī, a 7-Yaman:

al-Insān wa-al-Hađărah, Dār al-Tanwīr li-Tabācah wa-al-Nashr, Beirut, 1985.

al-Shanti 1985:

Isam Mohammed Al-Shanti, The Arabic Manuscripts microfilmed by the Institute of Arab Manuscripts from the Manuscripts House in Sana' [sic], Kuwait, 1985.

al-Sharjabi 1986:

Qā'id Nucmān a1-Sharjabī, al-Sharä'ih al-ijtimācīyah

a7-taq $\overline{7} d \overline{7} y a h$ fì a7-Mujtamac a 1-Yaman̄in, Dār al-Hadāthah, Sanc' $\overline{\mathrm{a}}, 1986$.

al-Sharjabi 1990:

Qā'id Nucmān al-Sharjabī, a7-Qaryah wa-a7-Dawlah fi

a 1-Mujtamac al-Yaman̄̄, Dār al-Tađāmun, Sancā', 1990.

Sharma and Drèze 1990:

Naresh Sharma and Jean Drèze, Share-Cropping in Palanpur, The Development Economics Research Programme of the L.S.E., No. 30, 1990.

Smith 1776:

Adam Smith, An Inquiry into the Nature and Causes of the Wealth of Nations, London 1776; bicentenary repr. 1976, oxford. 
Smith 1969:

G.R. Smith, "The Ayyūbids and Rasūlids: the transfer of power in $7 \mathrm{th} / 13 \mathrm{th}$ century Yemen", Islamic Culture, 43 (1969) :175-188.

Spuler 1961:

Bertold Spuler, New Edition of Wüstenfeld-Mahler'sche Vergleichungs-Tabellen, Wiesbaden, 1961.

Strothmann $E I^{1}$ :

R. Strothmann, $E I^{1}$, article "al-Zaidiyya".

Strothmann $E I^{2}$ :

R. Strothmann (revised G.R. Smith and J.R. Blackburn), EI ${ }^{2}$, article "Al-Mahdī li-Dīn Allāh Ahmad".

al-Sulmî 1993:

Mubammad bn Yahyā bn ${ }^{\mathrm{c} A 1} \overline{1}$ al-Sulmī, Nazarīyat a ${ }^{-c}$ uqūbah fi

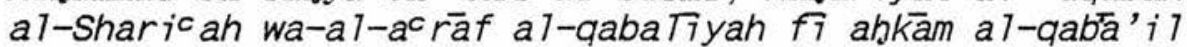

a 7-yaman̄ìah wa-mafhüm a 1-naqā' wa-a 7-cayb, \$anc̄̄', $1413 / 1993$.

Tabātabā'’̄ 1983:

Hossein Modarressi Tabātabā' $\bar{\imath}$, Kharāj in Islamic Law, London, 1983.

Tritton 1925:

A.S. Tritton, The Rise of the Imams of Sanaa, Oxford, 1925.

UN 1987:

United Nations Joint Economic and Social Commission for Western Asia and the Food and and Agriculture Organisation, Crop-Sharing and Land-Tenancy Practices in the Yemen Arab Republic, Report ref. E/ESCWA/AGR/87/6, 28 October 1987.

Van Arendonk 1960:

C. Van Arendonk, Les Débuts de 7'Imamat zaidite au Yémen, translated into French by Jacques Ryckmans, Leiden, 1960.

Van Den Berg 1896:

L.W.C. Van Den Berg, Principes du Droit musulman selon les rites d'Abou Haniffah et de Châfi' $\hat{r}$, first published in Dutch, Batavia; translated from the Dutch by $R$. de France de Tersant, Algiers, 1896.

Varisco 1982:

Daniel M. Varisco, The Adaptive Dynamics of Water Allocation in al-Ahjur, Yemen Arab Republic, Unpublished Ph.D. Thesis, University of Pennsylvania, 1982.

Veccia Vaglieri $E I^{2}$ :

L. Veccia Vaglieri, EI ${ }^{2}$, article "Khaybar".

Wakin $E I^{2}$ :

Jeanette A. Wakin, EI $I^{2}$ article "Muđăraba". 
Watt 1956:

W. Montgomery Watt, Mubammad at Medina, Oxford U.P., 1956.

Wehr 1971:

Hans Wehr, A Dictionary of Modern Written Arabic, edited by J. Milton Cowan, Wiesbaden and London.

Young $E I^{2} \mathrm{a}$ :

M.J.L. Young, EI², article "Musāqāt".

Young $E I^{2} \mathrm{~b}$ :

M.J.L. Young, EI $I^{2}$, article "Muzāraca".

Young, Latham and Serjeant (eds.) 1990:

M.J.L. Young, J.D. Latham and R.W.B. Serjeant (eds.), Religion, Learning and Science in the cAbbasid Period, Cambridge, 1990.

Youssef 1991:

A.A. Youssef, "Terrain mapping units of the northern regions of the Republic of Yemen", Majallat KulTiyat a 7-Adāb, University of Sanc $\bar{a}$, 13 (1991) :1-29.

Yusuf 1957:

S.M. Yusuf, "Land, agriculture and rent in Islam", Islamic Cu7ture, $31: 27-39$.

Ziadeh 1959:

F.J. Ziadeh, "curf and law in Islam", The World of Islam: Studies in honour of Philip K. Hitti, eds. J. Kritzeck and R.B. Winder, London, 1959, :60-67. 